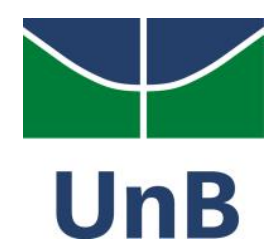

UNIVERSIDADE DE BRASÍLIA

CENTRO DE ESTUDOS AVANÇADOS MULTIDISCIPLINARES

PROGRAMA DE PÓS-GRADUAÇÃO EM DESENVOLVIMENTO, SOCIEDADE

E COOPERAÇÃO INTERNACIONAL

MAURÍCIO SUHETT SPÍNOLA

PARTICIPAÇÃO SOCIODIGITAL E DESENVOLVIMENTO NA CÂMARA DOS DEPUTADOS 
UNIVERSIDADE DE BRASÍLIA

CENTRO DE ESTUDOS AVANÇADOS MULTIDISCIPLINARES

PROGRAMA DE PÓS-GRADUAÇÃO EM DESENVOLVIMENTO, SOCIEDADE E COOPERAÇÃO INTERNACIONAL

\author{
MAURICIO SUHETT SPÍNOLA
}

\title{
PARTICIPAÇÃO SOCIODIGITAL E DESENVOLVIMENTO NA CÂMARA DOS DEPUTADOS
}

Tese apresentada como requisito parcial para a obtenção do Título de Doutor em Desenvolvimento, Sociedade e Cooperação Internacional pelo Programa de Pós-Graduação do Centro de Estudos Avançados e Multidisciplinares da Universidade de Brasília.

Área de Concentração: Desenvolvimento e Políticas Públicas.

Orientador:

Prof. Dr. Ricardo Wahrendorff Caldas

BRASÍLIA

2015 


\section{FICHA CATALOGRÁFICA}

Spínola, Mauricio Suhett

Participação Sociodigital e Desenvolvimento na Câmara dos Deputados / Mauricio Suhett Spínola; orientador Ricardo Wahrendorff Caldas. -- Brasília, 2015. 200 p.

Tese (Doutorado em Desenvolvimento, Sociedade e Cooperação Internacional) -- Universidade de Brasília, 2015.

1. Desenvolvimento. 2. Participação política. 3. Democracia digital. I. Caldas, Ricardo Wahrendorff, orient. II. Título. 


\section{MAURICIO SUHETT SPÍNOLA}

\section{PARTICIPAÇÃO SOCIODIGITAL E DESENVOLVIMENTO NA CÂMARA DOS DEPUTADOS}

Tese apresentada como requisito parcial para a obtenção do Título de Doutor em Desenvolvimento, Sociedade e Cooperação Internacional pelo Programa de Pós-Graduação do Centro de Estudos Avançados e Multidisciplinares da Universidade de Brasília.

Área de Concentração: Desenvolvimento e Políticas Públicas.

\section{COMISSÃO EXAMINADORA}

Professor Doutor Ricardo Wahrendorff Caldas, professor do PPDSCI/CEAM/UnB, orientador

Professor Doutor Michelangelo Giotto Santoro Trigueiro, professor do Departamento de Sociologia/UnB, membro

Professor Doutor Wilson de Jesus Beserra de Almeida, professor do Mestrado em Direito e do Curso de Relações Internacionais da Universidade Católica de Brasília, membro

Professora Doutora Julia Dolores Schmied Zapata, professora do mestrado e doutorado no Instituto de Relações Internacionais (IREL/UnB) e professora do PPDSCI/CEAM/UnB, membro Professora Doutora Leila Chalub-Martins, professora da Faculdade de Educação/UnB,
membro

Professora Doutora Maria Elenita Menezes Nascimento, professora do mestrado no CET/ UnB, suplente

Brasília, 11 de dezembro de 2015 


\section{DEDICATÓRIA}

À minha esposa Rosa Cleide, companheira de sonhos, aventuras e desventuras. À minha filha Larissa e meu filho Matheus, meus amigos, que potencializaram a alegria de viver.

Aos meus pais, Raimundo e Ermita, que me deram raízes e asas. Aos meus irmãos Márcio e Charles, e minha irmã Andréa. Ao meu sogro Asclepíades e minha sogra Rosélia. 


\section{AGRADECIMENTOS}

A Deus, minha esperança, que dá sentido à caminhada!

À minha esposa Rosa Cleide, pelos risos e choros comuns. Pelo apoio constante.

À minha filha Larissa e meu filho Matheus, meus amigos.

Ao professor Ricardo Caldas, por se disponibilizar a me orientar.

À professora Viviane Resende, pela troca de ideias e pistas metodológicas, fundamentais para os rumos da pesquisa.

Aos professores Michelangelo Trigueiro e Wilson de Jesus Beserra de Almeida, e às professoras Julie Schmied, Leila Chalub-Martins e Maria Elenita Menezes Nascimento, pela participação em minha defesa de tese.

Aos colegas da Câmara dos Deputados:

Walternor Brandão, Joanita Nascimento da Silva Neta e Gisele Villas Boas - pela colaboração com a pesquisa. Em especial ao Walternor pela ajuda na aplicação do questionário.

Cristiane Brum Bernardes, Antônio Teixeira de Barros e Roberto Campos da Rocha Miranda - pela leitura da tese e valiosas críticas e considerações.

Joao Vianney Barrozo Costa Severo, pela ajuda com as planilhas eletrônicas.

Heber Jorge Brandão e Evandro Tadeu Moreira, pelo apoio.

Marcus Vinicius Chevitarese Alves, pela ajuda com a coleta dos dados de financiamento de campanhas eleitorais.

Vinicius de Morais Alves, pelas discussões conceituais e metodológicas.

João Luiz Pereira Marciano, pela ajuda com o software R e análises estatísticas.

Aos colegas da pós-graduação do CEAM, pelo convívio, trocas e conversas. 
“A riqueza não é, evidentemente, o bem que procuramos: é algo de útil, nada mais, e ambicionado no interesse de outra coisa"

(Aristóteles)

"Tomai a resolução de não mais servirdes e sereis livres. Não vos peço que o empurreis ou o derrubeis, mas somente que o não apoieis: não tardareis a ver como, qual Colosso descomunal, a que se tire a base, cairá por terra e se quebrará" (Étienne de La Boètie)

"Todo vale será aterrado e todas as montanhas e colinas, niveladas. As estradas tortuosas serão endireitadas e os caminhos acidentados, aplanados"

(João Batista) 


\section{RESUMO}

A presente tese aborda o tema do desenvolvimento no contexto da política, em suas conexões com a participação política sociodigital, aquela realizada através da mediação das Tecnologias da Informação e Comunicação (TICs). O potencial democratizante das TICs, a relação entre financiamento empresarial de campanhas eleitorais e o comportamento dos deputados federais, as potenciais correlações entre a dinâmica da participação sociodigital, o comportamento dos parlamentares e o financiamento empresarial foram investigados a partir do estudo da dinâmica da participação sociodigital na Câmara dos Deputados quanto à efetividade, inclusão e efeitos de socialização sobre os participantes. Adicionalmente, foram analisadas as implicações da dinâmica da participação sociodigital na Câmara dos Deputados para o desenvolvimento enquanto ampliação das oportunidades substantivas de influenciar o processo político. Os resultados obtidos apresentam evidências de uma inefetividade da participação sociodigital no caso em estudo, quanto à capacidade dos cidadãos de influenciar as decisões do corpo político. Os resultados apontaram, ainda, para uma relação causal entre o direcionamento da responsividade dos deputados federais aos interesses dos atores do mercado, e a inefetividade da participação popular. Finalmente, conclui-se que a observada inefetividade da participação popular contribui para a produção de uma subcidadania e uma condição de subdesenvolvimento, que conjuntamente descrevem a formação de um contingente de cidadãos-dependentes, despossuídos dos recursos materiais e legais que poderiam reposicioná-los como atores centrais no jogo político, enfatizando a dimensão política do conceito de ralé cunhado por Jessé Souza.

Palavras-chave: desenvolvimento; democracia; participação sociodigital; soberania popular 


\begin{abstract}
This thesis addresses the issue of development in the context of politics in its connections with the sociodigital political participation, that is held through the mediation of Information and Communication Technologies (ICT). The democratizing potential of ICT, the relationship between business financing of electoral campaigns and the behavior of federal deputies, the potential correlations between the dynamics of sociodigital participation, the behavior of parliamentarians and the business financing were investigated based on the study of the dynamics of sociodigital participation in the Chamber of Deputies regarding the effectiveness, inclusion and socialization effects on participants. Additionally, we analyzed the dynamics of the implications of sociodigital participation in the Chamber of Deputies for the development as the expansion of substantive opportunities to influence the political process. The results show, in this case, evidence of the ineffectiveness of sociodigital participation regarding the ability of citizens to influence the political decisions. The results also pointed to a causal relationship between the direction of the federal deputies' responsiveness to the interests of market players and the ineffectiveness of popular participation. Finally, it is concluded that the observed ineffectiveness of popular participation contributes to the production of undercitizenship and underdevelopment conditions, which together describe the formation of dependent citizens, lacking material and legal resources that could reposition them as key players in the political game, emphasizing the political dimension of Jesse Souza's concept of "ralé".
\end{abstract}

Keywords: development; democracy; sociodigital participation; popular sovereignty 


\section{LISTA DE FIGURAS}

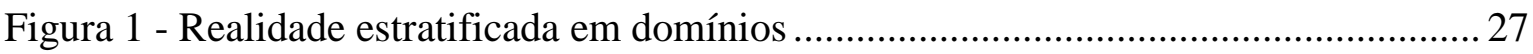

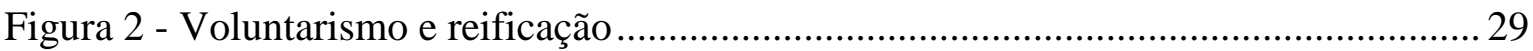

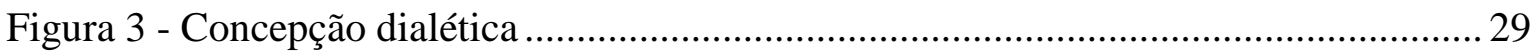

Figura 4 - Modelo Transformacional da Atividade Social ................................................. 30

Figura 5 - Objetivo (conceito), teoria e estratégia de desenvolvimento ............................. 32

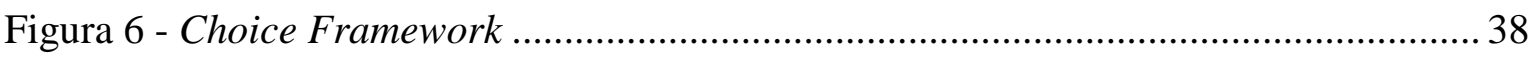

Figura 7 - Responsividade do sistema político .................................................................. 43

Figura 8 - Ecossistema Político a partir da Câmara dos Deputados .................................... 44

Figura 9 - Formas de avaliação da participação ................................................................. 55

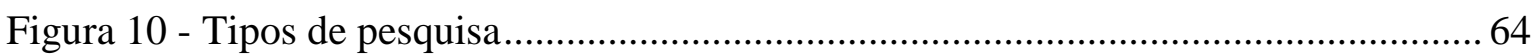

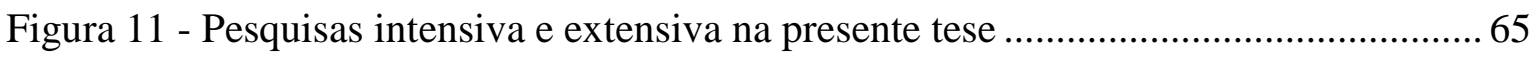

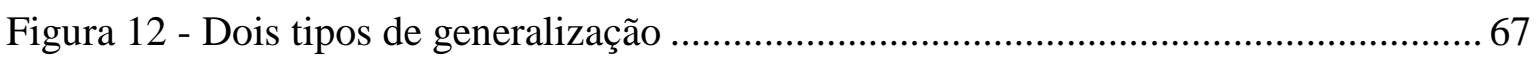

Figura 13 - Método explanatório para o objeto de pesquisa ............................................. 73

Figura 14 - Procedimento de análise da influência.............................................................. 76

Figura 15 - Responsividade e grau de responsividade. ..................................................... 81

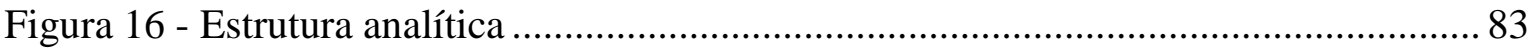

Figura 17 - Distribuição da Responsividade à Indústria (RI) ........................................... 91

Figura 18 - Distribuição do Grau de Responsividade à Indústria (GRI) ............................ 92

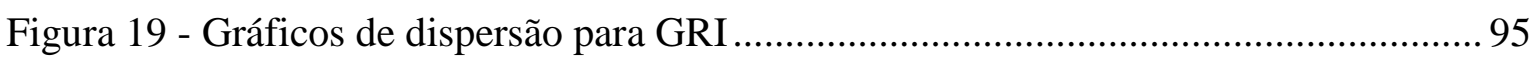

Figura 20 - Valores preditos (estimados) de GRI em função de PD ................................... 99

Figura 21 - Probabilidade de cooperação com a Indústria em função de PI ...................... 103

Figura 22 - Probabilidade de cooperação com a Indústria em função de PD ..................... 104

Figura 23 - Probabilidade de cooperação com a Indústria em função de PD, para M3 ... 106

Figura 24 - Autopercepção da eficácia da participação..................................................... 108

Figura 25 - Cidadãos que receberam resposta às suas manifestações ............................... 111

Figura 26 - Regularidade de utilização do e-Democracia ................................................. 114

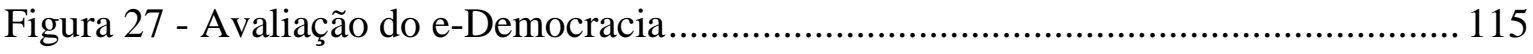

Figura 28 - Satisfação com demais canais de participação da Câmara .............................. 116

Figura 29 - Grau de satisfação com a democracia brasileira......................................... 117

Figura 30 - Democracia como melhor sistema de governo ........................................... 120 
Figura 31 - Satisfação com democracia brasileira e autopercepção da eficácia da participação.

Figura 32 - Autopercepção da eficácia da participação e regularidade de uso do eDemocracia.....

Figura 33 - Resposta da Câmara e autopercepção da eficácia da participação

Figura 34 - Resposta da Câmara e regularidade de uso do e-Democracia

Figura 35 - Democracia como melhor sistema e satisfação com democracia brasileira ... 124

Figura 36 - Escolaridade e percepção da eficácia da participação 125

Figura 37 - Escolaridade e percepção da eficácia da participação (percentuais) 126

Figura 38 - Relação do pertencimento a entidades e outras dimensões 126

Figura 39 - Relação entre receber resposta da Câmara e imagem do e-Democracia perante participantes.

Figura 40 - Relação entre percepção da eficácia da participação e satisfação com os demais canais de participação

Figura 41 - Relação entre percepção da eficácia da participação e satisfação com os demais canais de participação (percentuais)

Figura 42 - Relação entre resposta da Câmara às manifestações e satisfação com os demais canais de participação

Figura 43 - Relação entre resposta da Câmara às manifestações e satisfação com os demais canais de participação (percentuais) 134

Figura 44 - Mapa de relações de causalidade. 135

Figura 45 - Respondentes por UF

Figura 46 - Proporção de homens e melhores entre os respondentes 138

Figura 47 - Respondentes por faixa etária 139

Figura 48 - Distribuição dos respondentes por grau de escolaridade 140

Figura 49 - Zonas de protagonismo cívico 148

Figura 50 - Resumo dos Resultados da pesquisa. 151

Figura 51 - Respostas à pergunta aberta 195

Figura 52 - Questionário para pesquisa intensiva 198 


\section{LISTA DE TABELAS}

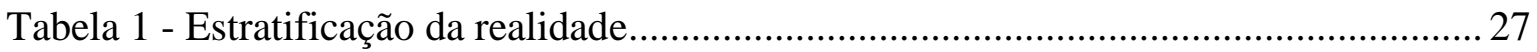

Tabela 2 - Critérios de avaliação da participação................................................................. 58

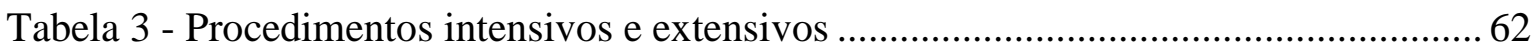

Tabela 4 - Dimensões e métodos para avaliação da participação ....................................... 77

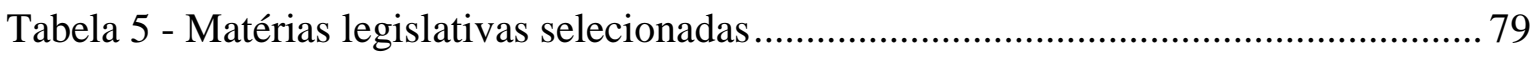

Tabela 6 - Modelagem da análise de responsividade ….................................................. 84

Tabela 7 - Manifestações dos cidadãos para as matérias legislativas................................... 85

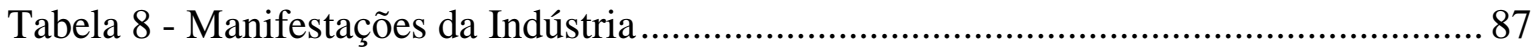

Tabela 9 - Quadro de matérias e votos, após exclusão de M1 e M2 …................................ 87

Tabela 10 - Resumo votação para as matérias M3 a M7 ................................................... 88

Tabela 11 - Grau de alterações nos textos das proposições................................................. 89

Tabela 12 - Matérias para análise de responsividade ....................................................... 90

Tabela 13 - Valores absolutos e percentuais para a distribuição de GRI ............................ 93

Tabela 14 - Análise das bancadas para faixas de PI e PJ................................................... 94

Tabela 15 - Resultados da regressão de Poisson para GRI................................................. 98

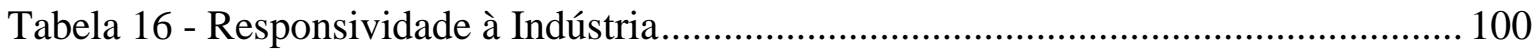

Tabela 17 - Tabela de classificação para modelo 2 (M3 + M4 + M5) .............................. 102

Tabela 18 - Tabela de classificação para modelo 8 (M3) ................................................ 105

Tabela 19 - Resultados da análise de desenvolvimento humano .................................... 147

Tabela 20 - Votos nominais para a matéria M3 …........................................................... 162

Tabela 21 - Votos nominais para a matéria M4 .............................................................. 172

Tabela 22 - Votos nominais para a matéria M5 .............................................................. 183

Tabela 23 - Respostas às perguntas de múltipla escolha .................................................. 194 


\section{LISTA DE SIGLAS}

CA Capability Approach

CLP Comissão de Legislação Participativa

CNAE Classificação Nacional de Atividades Econômicas

CNI Confederação Nacional da Indústria

CPP Coordenação de Participação Popular

GR Grau de Responsividade

GRC Grau de Responsividade aos Cidadãos

GRI Grau de Responsividade à Indústria

IBGE Instituto Brasileiro de Geografia e Estatística

IP Instituição Participativa

IPEA Instituto de Pesquisa Econômica Aplicada

MPV Medida Provisória

ONG Organização Não Governamental

PEC Proposta de Emenda à Constituição

PIB Produto Interno Bruto

PL Projeto de Lei

PMC Pluralismo Metodológico Crítico

PNBL Plano Nacional de Banda Larga

RC Responsividade aos Cidadãos

RI Responsividade à Indústria

RICD Regimento Interno da Câmara dos Deputados

SECOM Secretaria de Comunicação Social

TICS Tecnologias de Informação e Comunicação

TMSA Transformational Model of Social Activity

UDR Human Development Report

UF Unidade da Federação

UFMG Universidade Federal de Minas Gerais

UFPE Universidade Federal de Pernambuco

UNDP United Nations Development Programme 


\section{SUMÁRIO}

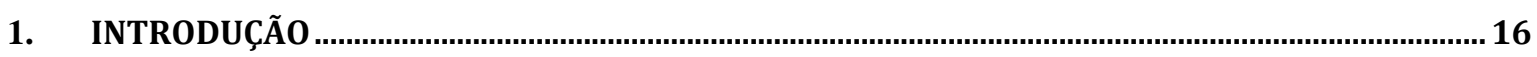

2. BREVE HISTÓRICO DA PARTICIPAÇÃO POPULAR NA CÂMARA DOS DEPUTADOS ....................24

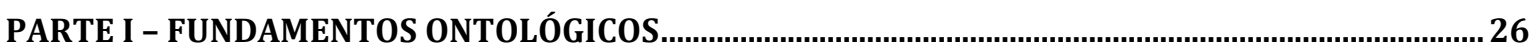

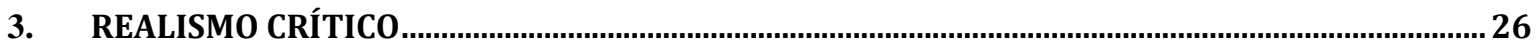

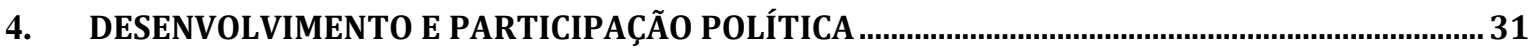

4.1. DeSenvolvimento Humano E A AboRdagem das CaPaCidadeS ..................................................................

4.2. TECNOLOGIAS DA ESCOLHA: CHOICE FRAMEWORK ……….......................................................................

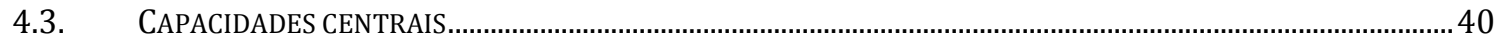

5. A SEPARAÇÃO ENTRE O “POLÍTICO” E O “ECONÔMICO”.............................................................. 45

6. O DEBATE EM TORNO DA DEMOCRACIA DIGITAL.................................................................... 49

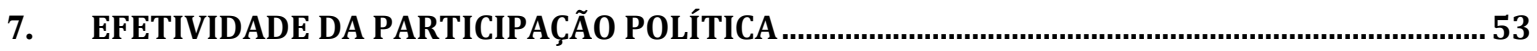

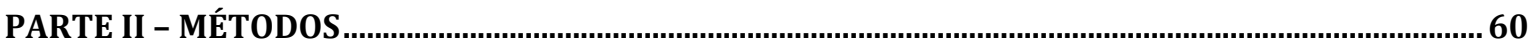

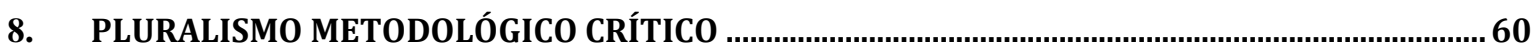

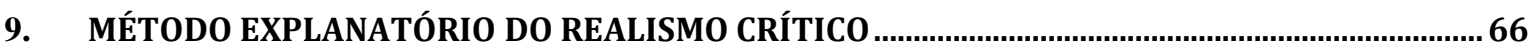

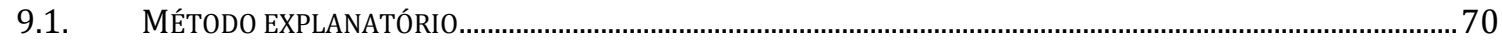

PARTE III - ESTUDO DE CASO ……...................................................................................................... 74

10. ESTRUTURAÇÃO DO ESTUDO DE CASO ……........................................................................... 74

11. RESPONSIVIDADE DOS DEPUTADOS - MODELAGEM QUANTITATIVA ……................................78

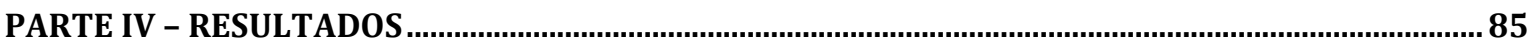

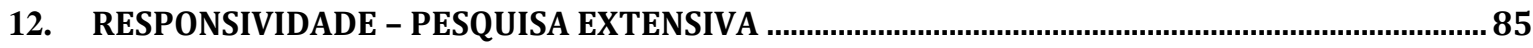

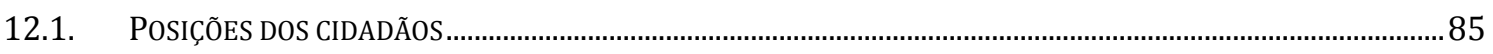

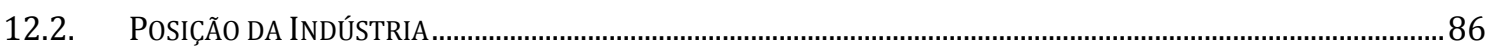

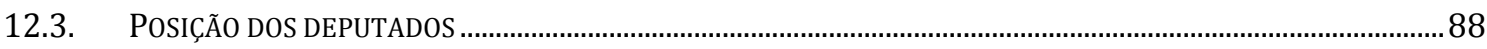

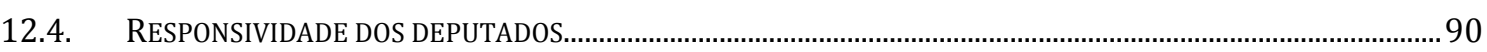

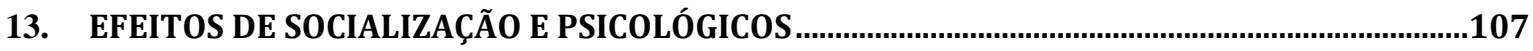

13.1. AUTOPERCEPÇÃO DA CAPACIDADE DE AGIR DOS CIDADÃOS......................................................................

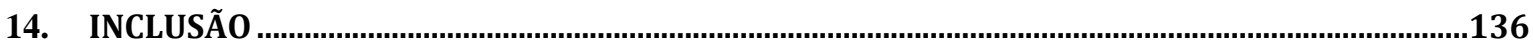

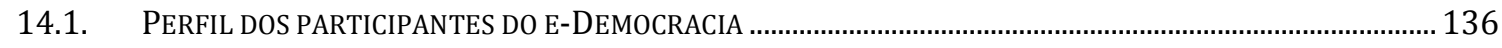


PARTE V - DISCUSSÃO: PARTICIPAÇÃO E DESENVOLVIMENTO NA CÂMARA...................................146

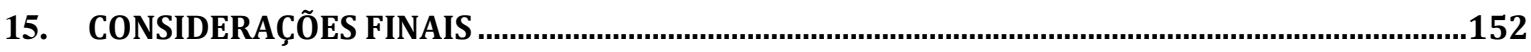

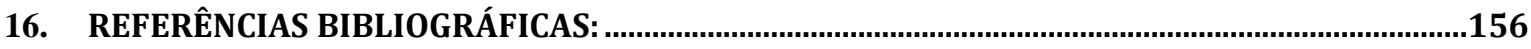

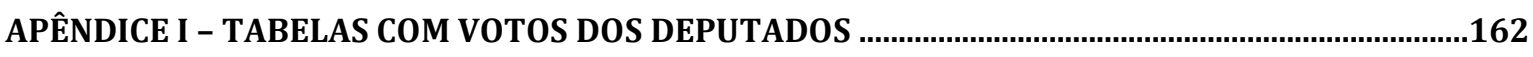

APÊNDICE II - RESPOSTAS AO QUESTIONÁRIO _...............................................................................

APÊNDICE III - QUESTIONÁRIO ……........................................................................................198 


\section{Introdução}

Os temas do desenvolvimento, das novas Tecnologias da Informação e Comunicação (TICs) e da participação política, e a relação entre eles, constitui objeto de investigação da presente pesquisa. Cada um dos temas em separado tem sido alvo de disputas normativas pelas mais diversas áreas disciplinares, entre economia, sociologia, antropologia e ciência política.

Os muitos sentidos do desenvolvimento, por exemplo, vão desde crescimento econômico até ganhos em felicidade. Para a disciplina da Economia do Desenvolvimento, desenvolver significa essencialmente promover o incremento da riqueza econômica de um país ou região, expresso em taxas positivas de aumento do Produto Interno Bruto (PIB) per capita. A preocupação incide sobre possíveis interrelações entre a dinâmica de mercado, arranjos institucionais, globalização, políticas industriais e de comércio, e variáveis macroeconômicas e os potenciais efeitos sobre dimensões ligadas ao bem-estar de uma população.

Somente em anos mais recentes as pesquisas sobre desenvolvimento começaram a analisar de forma mais profunda e sistemática os processos de desenvolvimento como processos, ao mesmo tempo, econômicos e político-culturais. Estudos sobre a colonização, teorias da dependência, teorias da modernidade, estudos sobre pobreza e desigualdade socioeconômica são algumas das abordagens teóricas que trabalham com noções mais ampliadas acerca do desenvolvimento.

Inglehart e Welzel (2005), por exemplo, elaboraram uma teoria do desenvolvimento que parte da premissa de que, a despeito das significativas diferenças culturais existentes entre as nações, uma mudança nos valores estaria ocorrendo associada ao desenvolvimento econômico experimentado a partir da segunda metade do século XX, principalmente pelas sociedades industriais avançadas ou pós-industriais. Tal mudança estaria provocando alterações profundas no campo religioso, no mundo do trabalho, nas relações de gênero, nas normas sexuais e na atividade política (INGLEHART, 1977; 1990; 2001). No campo político, esse fenômeno teria consequências positivas sobre os processos 
de democratização, pois estaria associado à adoção de valores e atitudes congruentes com essa forma de governo (INGLEHART; WELZEL, 2005).

Com relação às novas Tecnologias da Informação e Comunicação (TICs), as pesquisas produzidas nas últimas duas décadas no Brasil restringem, em geral, seus esforços na investigação de possíveis relações causais entre o acesso e uso de tais tecnologias e os potenciais impactos em termos de ganhos de produtividade para setores específicos da economia ou da ampliação do acesso a tecnologias comunicativas como a Internet, a "inclusão digital”. Outros estudos exploram o potencial das TICs para a inclusão produtiva de indivíduos no mercado de trabalho (MARISCAL; BOTELHO; GUTIÉRREZ, 2008) ou buscam investigar possíveis correlações entre o aumento da penetração da Internet na modalidade banda larga e incrementos no Produto Interno Bruto (PIB) brasileiro sem, contudo, apresentar evidências de relações causais entre os dois eventos (IPEA, 2010).

No campo da ciência política, a questão do desenvolvimento aparece tangencialmente nos estudos sobre avaliação de políticas públicas, na busca por identificar potenciais impactos da implantação e execução de uma política sobre certos indicadores sociais.

A presente pesquisa se distancia de concepções do desenvolvimento com viés estritamente econômico, optando pelas contribuições de um conjunto de autores, particularmente Amartya Sen e Martha Nussbaum, que propuseram uma redefinição do desenvolvimento como um processo de ampliação das escolhas ou liberdades substantivas dos indivíduos (SEN, 1999; NUSSBAUM, 2011). Esta corrente teórica ficou conhecida como a abordagem do Desenvolvimento Humano.

Pretende-se contribuir para o campo dos estudos sobre o desenvolvimento ao tentar compreendê-lo à luz das recentes iniciativas de democracia digital. Busca-se entender a dinâmica da participação sociodigital, aquela que acontece pela mediação das TICs, e as implicações para o desenvolvimento concebido como processo de ampliação das escolhas ou oportunidades de influenciar as decisões políticas. 
Citando Kelsen, Adam Przeworski lembra-nos que "Politicamente livre é quem está sujeito a uma ordem legal de cuja criação participou" (KELSEN, 1949, p. 284 apud PRZEWORSKI, 2010, p. 109). Ainda segundo Przeworski, os sistemas legais diferem não apenas sobre os resultados que geram, mas também sobre o que permitem a indivíduos alcançar por suas próprias ações; diferem no quanto permitem escolhas individuais.

As leis moldam o que Sen (1988) chama de "conjuntos de capacidades", definido como um agrupamento de "funcionamentos" que uma pessoa pode alcançar por suas próprias ações. Uma vez que os conjuntos de capacidades incluem a habilidade de exercer escolhas, não são exauridos pelo consumo de comodities ou entretenimento (PRZEWORSKI, 2010, p. 150).

O fato, apontado por Przeworski, de que "as leis moldam o conjunto de capacidades" coloca a instituição política responsável pela elaboração das leis, o Congresso Nacional, no centro das discussões sobre o desenvolvimento humano, na medida em que parte significativa da estrutura social é constituída pelo conjunto de instrumentos normativos que exercem um efeito regulador das relações sociais ao produzir constrangimentos e/ou possibilidades para a ação dos indivíduos com vistas à realização de seus objetivos de vida.

A democracia tem sido, de forma recorrente, confrontada por quatro desafios que continuam, ainda hoje, alimentando intensa insatisfação nos cidadãos: (1) a incapacidade de gerar igualdade na esfera econômica, (2) a incapacidade de fazer com que as pessoas sintam que sua participação política é efetiva, (3) a incapacidade de garantir que os governos façam o que supostamente devem fazer e não o que não tem mandato para realizar, e (4) a incapacidade de achar um equilíbrio entre ordem e não-interferência (PRZEWORSKI, 2010).

O desafio de "fazer com que as pessoas sintam que sua participação política é efetiva" é de suma importância para o processo de desenvolvimento humano. Cidadãos que percebem que seus esforços de participação não são recompensados em termos de capacidade de influenciar as decisões políticas que irão regular suas vidas, tendem a desistir da esfera pública, restringindo suas ações ao domínio do privado. Essa desistência 
da esfera pública cria uma situação de heteronomia, isto é, a submissão do indivíduo à vontade de terceiros, em contraposição à condição de autonomia.

Com o advento e a disseminação das novas Tecnologias da Informação e Comunicação (TICs), especialmente a Internet e a comunicação móvel, surgem expectativas sobre o potencial democratizante dessas tecnologias para superar os desafios colocados, particularmente a necessidade de uma participação política mais efetiva por parte dos cidadãos para a preservação e fortalecimento dos princípios do autogoverno, da autodeterminação e soberania popular.

As expectativas em torno do potencial democratizante das TICs ganham maior fôlego diante da atual crise de legitimidade das democracias representativas contemporâneas. Para Maia, Gomes e Marques,

O sistema político contemporâneo tende, como se sabe, a se desconectar da base civil da sociedade (da cidadania, em suma), exceto pelo episódio eleitoral, quando os cidadãos entram com os votos e o sistema político provê o pessoal especializado para ser votado e escolhido para constituir a esfera da representação política. A excessiva autonomia do sistema político traz consigo frequente e crescentemente uma (ilegítima) autonomia da esfera da decisão política, que controla a forma institucional da comunidade política, que é o Estado, praticamente sem liame que a mantenha atada e submetida ao controle daquele que desta comunidade deve ser o único soberano, o cidadão. Por isso, tornou-se um hábito o argumento que sustenta, em sede teórica, que o governo representativo tende a produzir um avanço colonizador do sistema político sobre o território dos direitos de participação direta e efetiva do cidadão nos negócios públicos (MAIA; GOMES; MARQUES, 2011, p. 25).

É esta desmedida autonomia do sistema político em relação à base civil da sociedade que está na raiz da crise de legitimidade das democracias representativas. Percebe-se um esgotamento do modelo da democracia eleitoral diante das recentes demandas por maior proximidade entre as instituições políticas e a sociedade, e por maior 
responsividade e transparência do corpo político. Ao que parece, a cidadania se tornou mais exigente e reivindica maior controle sobre as decisões políticas.

Embora o conceito de cidadania seja fluido e contestado em muitos sentidos, podese identificar essencialmente dois tipos ou noções de cidadania. Primeiramente, uma concepção legal-jurídica que se refere à condição de membro oficial de uma comunidade política (um Estado-nação, em geral). Neste caso, ser um cidadão significa possuir um passaporte ou direito de residência.

Pode-se, adicionalmente, conceber a cidadania como ser membro de um corpo político potencialmente mais ativo, capaz de exercer influência democrática sobre outros cidadãos e sobre o Estado. Essa concepção de cidadania enfatiza a importância de três formas de participação: (1) obtenção de informação com o fim de ter acesso a narrativas equilibradas de fontes plurais sobre questões políticas; (2) deliberação, que envolve conversar com outros cidadãos, de forma honesta e aberta, sobre questões políticas e (3) esforços ativos por influenciar decisões e políticas públicas (COLEMAN; BLUMLER, 2009).

Esta última acepção de cidadania como pertencimento ativo a um corpo político é precisamente o foco da presente tese, que procura avaliar a capacidade dos cidadãos de exercer influência democrática sobre decisões e políticas públicas, em particular sobre as decisões públicas tomadas pelos deputados federais na Câmara dos Deputados.

Considerando os contínuos e crescentes desgastes de legitimidade das instituições da democracia representativa em função do distanciamento cada vez maior entre representantes e representados, estudar iniciativas de participação sociodigital e seu potencial de ampliação das oportunidades (escolhas) de influenciar as decisões políticas, viabilizando uma apropriação social do poder político (ROSANVALLON, 2011), reveste a presente pesquisa de importância e oportunidade.

Um dos principais problemas das democracias liberais contemporâneas não é a participação em sentido estrito, mas o da fraca capacidade concorrencial da cidadania em face de outros agentes e outras agências com interesses políticos (MAIA; GOMES; MARQUES, 2011). Embora vulnerável, o potencial da Internet e das redes sociais de 
fortalecer a capacidade concorrencial do cidadão frente a agentes mais instrumentalizados para prevalecer no jogo para influenciar o processo político está atrelado à redução dos custos de participação. A transformação dos espaços físicos em espaços virtuais de participação, viabilizada pela comunicação via Internet, relativiza a necessidade de presença física para o engajamento nos processos de deliberação pública, reduzindo, assim, o custo da participação política.

É preciso lembrar, contudo, que esse potencial da Internet é vulnerável na medida em que está constantemente sujeito à possibilidade de não-realização pela ação de fatores ligados ao contexto da participação - cultura de participação, desenho institucional, configuração do processo de tomada de decisões políticas, por exemplo.

O reconhecimento do caráter contingencial do potencial da Internet de ampliação da capacidade concorrencial dos cidadãos nos espaços de decisão pública remete à necessidade de compreender a dinâmica da participação sociodigital e os mecanismos que possam estar associados à sua efetividade.

É oportuno, portanto, diante das novas possibilidades de descolonização do território da cidadania, franqueadas por tecnologias comunicacionais como a Internet, inquirir sobre seu potencial de recomposição de padrões adequados de soberania popular nas democracias representativas.

Quanto aos objetivos, em termos gerais, a pesquisa busca estudar a relação entre participação política sociodigital, aquela realizada através da mediação das TICs, e o desenvolvimento humano, na Câmara dos Deputados. Como objetivos específicos, tem-se:

- Avaliar o potencial democratizante das TICs a partir da análise da dinâmica da participação sociodigital na Câmara dos Deputados quanto à efetividade da participação, a inclusão em termos de representatividade dos participantes em relação à diversidade da população brasileira, e efeitos de socialização sobre os participantes. A participação sociodigital na Câmara dos Deputados acontece através dos canais digitais de interação com a sociedade, disponibilizados pela Casa Legislativa. 
- Analisar a relação entre financiamento empresarial de campanhas eleitorais e o comportamento dos deputados federais, expresso pelos seus votos nominais, durante o ano de 2014 (final da $54^{\text {a }}$ legislatura) e o período de fevereiro a julho de 2015 (55 legislatura).

- Investigar potenciais correlações e relações causais entre a dinâmica da participação sociodigital, o comportamento dos parlamentares e o financiamento empresarial de suas campanhas, principalmente quanto à

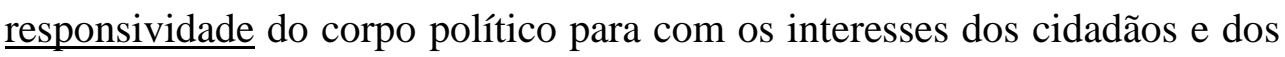
doadores de campanha.

- Verificar as implicações da dinâmica da participação sociodigital na Câmara dos Deputados para o desenvolvimento como ampliação das oportunidades (escolhas) substantivas de influenciar as decisões políticas.

O conceito de responsividade adotado para este trabalho de pesquisa está associado à suscetibilidade dos representantes às preferências dos eleitores, ou seja, à capacidade dos governantes de adotar as políticas que os governados preferem (MANIN; PRZEWORSKI; STOKES, 1999).

Associadas aos objetivos, há um leque de perguntas para as quais a pesquisa se propõe encontrar respostas. A pergunta central da pesquisa, associada ao objetivo geral, é posta da seguinte forma:

- Como se apresenta a relação entre participação política sociodigital, aquela realizada por meio da mediação das TICs, e o desenvolvimento humano?

Outras perguntas, associadas aos objetivos específicos, são:

- Existem evidências sobre a efetividade da participação sociodigital na Câmara dos Deputados em termos da capacidade dos cidadãos de influenciar as decisões do corpo político?

- Existem evidências de que a participação sociodigital na Câmara dos Deputados está resultando numa percepção, por parte dos participantes, de que estão mais influentes em relação às decisões políticas? 
- Existem correlações e relações causais entre a dinâmica da participação sociodigital na Câmara dos Deputados, o comportamento dos parlamentares e o financiamento empresarial de suas campanhas?

Para tentar responder estas perguntas, a pesquisa é desenvolvida a partir de uma estratégia que consiste em percorrer o caminho coerente e necessário entre ontologia, epistemologia e metodologia (MASON, 2002). O desenvolvimento da pesquisa inclui três momentos de reflexão. Primeiramente, uma reflexão ontológica que busca respostas para a seguinte pergunta de fundo: "Qual a natureza do fenômeno ou realidade social que pretende-se estudar?”. A reflexão ontológica consiste em perguntar-se sobre a essência das coisas no mundo social.

Por ser tão fundamental, a reflexão ontológica acontece logo no início do processo de pensamento, muito antes da identificação de um tópico em particular dentro do tema geral. Segundo Mason (2002), a ontologia pode parecer um conceito difícil precisamente porque a natureza e essência das coisas sociais parecem tão fundamentais e óbvias que pode ser difícil discernir o que precisa ser conceitualizado. Em particular, pode ser bastante difícil entender a idéia de que é possível ter uma posição ou perspectiva ontológica, uma vez que isso sugere que pode haver diferentes versões para a natureza e a essência dos "fatos" sociais.

Contudo, somente quando se reconhece que as perspectivas ontológicas alternativas podem contar diferentes estórias é que um pesquisador pode começar a ver a sua própria visão ontológica do mundo social como uma posição que deve ser estabelecida e compreendida, ao invés de uma óbvia e universal verdade dada a priori.

O segundo momento reflexivo no desenvolvimento da pesquisa foi a reflexão epistemológica, quando o pesquisador se ocupa em descobrir respostas para a seguinte pergunta: "O que pode representar conhecimento ou evidências da realidade social que pretende-se estudar?". Perguntas sobre o que consideramos conhecimento ou evidências das coisas no mundo social são questões epistemológicas. É importante distinguir questões sobre a natureza das evidências e do conhecimento - questões epistemológicas - daquelas aparentemente mais simples sobre como coletar dados. 
A reflexão epistemológica deve levar o pesquisador a ponderar questões filosóficas sobre o que exatamente deve ser considerado como evidência ou conhecimento sobre "fatos" do mundo social. As escolhas epistemológicas devem ajudar o pesquisador a gerar conhecimento e explicações sobre os componentes ontológicos do mundo social, sejam processos sociais, ações sociais, discursos ou significados (MASON, 2002).

O último momento é a reflexão metodológica, orientada na busca de possíveis respostas à pergunta: "Quais metodologias, consistentes com a ontologia e a epistemologia adotadas, permitem responder as perguntas de pesquisa?".

Com relação à estrutura e organização da tese, inicia com um breve histórico da participação popular na Câmara dos Deputados. Em seguida, na Parte I, apresentam-se as principais categorias e abordagens conceituais trabalhadas na pesquisa e sua relação com o tema da participação sociodigital. São apresentadas a perspectiva ontológica do Realismo Crítico, a teoria do desenvolvimento proposta por Amartya Sen e Martha Nussbaum e suas conexões com a participação política, o debate em torno da democracia digital e efetividade da participação.

Depois, na Parte II, descreve-se o Pluralismo Metodológico Crítico, método baseado na ontologia do Realismo Crítico, e as escolhas metodológicas da presente pesquisa. A Parte III da tese traz a construção do estudo de caso. Em seguida, são apresentados e analisados os resultados obtidos pela pesquisa (Parte IV), para então encerrar com uma discussão geral sobre os achados a partir dos fundamentos teóricos da tese e considerações finais.

\section{Breve histórico da participação popular na Câmara dos Deputados}

O processo histórico que culminou na atual estrutura de canais de participação popular da Câmara dos Deputados começou em 1998 com a criação do serviço DisqueCâmara, através do qual os cidadãos interagem com a Câmara, manifestando suas opiniões sobre assuntos diversos, de seu interesse. O serviço é estruturado em formato de uma 
central de relacionamento do tipo 0800 (Call Center) que recebe chamadas telefônicas dos cidadãos. Através deste canal a sociedade pode se manifestar sobre os proposições legislativas.

A partir de 1998 iniciou-se um processo de aprofundamento da interação da Câmara com a sociedade, não somente através do modal telefônico, mas também com outros canais. Uma das iniciativas foi a Carta Resposta que usava um envelope pré-pago pela Câmara, disposto em vários lugares do país, já com o campo para o cidadão preencher a sua mensagem e postar via correio convencional. A Câmara recebia uma grande quantidade de manifestações através deste canal. Havia um setor específico na Presidência da Câmara para fazer a classificação das manifestações e encaminhamento das respostas aos cidadãos.

Foi criado também o canal digital Fale Conosco que recebe por correio eletrônico as manifestações dos cidadãos. O Fale Conosco tem um campo que descrimina a classificação das mensagens recebidas, se sugestão, elogio ou manifestação. Depois veio a possibilidade do cidadão encaminhar diretamente para o deputado sua manifestação através do serviço Fale com o Deputado. Este serviço passou, então, a ser incorporado pelo Disque-Câmara. Em seguida, os programas da TV Câmara passaram a incorporar interação ao vivo com a população. Os cidadãos podiam enviar perguntas ou perguntar ao vivo para o parlamentar entrevistado ou deixar registrado seu comentário.

A Ouvidoria foi um canal institucionalizado para tratar denúncias, mas que também está aberto para que a sociedade possa se manifestar sobre outros assuntos. A criação do eDemocracia também foi uma ruptura muito importante, por conter várias ferramentas que favorecem a discussão e deliberação. Embora a discussão em si não redunde imediatamente numa decisão legislativa, ela já é um ganho.

O portal e-Democracia foi criado em 2009, depois que um grupo de servidores públicos da Assessoria de Projetos e Gestão da Câmara dos Deputados fizeram uma análise das principais experiências de participação no mundo. A análise sugeria que a Câmara também tivesse atuações de transparência e participação, como as experiências que eles tinham analisado. Foi criado um projeto piloto do e-Democracia em 2009. O projeto foi muito bem aceito pelos deputados, também pela direção administrativa da Câmara, dando- 
se continuidade ao mesmo. De 2009 até 2014, o e-Democracia funcionou como um projeto. Em 2014 foi criado o Laboratório Hacker da Câmara dos Deputados, fruto da experiência positiva da primeira maratona hacker realizada na Casa Legislativa. Neste momento, o e-Democracia passa a ser absorvido pela estrutura administrativa do Laboratório Hacker, criando-se uma seção de gestão do e-Democracia responsável pela evolução do portal e sua divulgação para a sociedade.

\section{PARTE I - FUNDAMENTOS ONTOLÓGICOS}

\section{Realismo Crítico}

O Realismo Crítico é um movimento na filosofia e nas ciências sociais associado ao trabalho de Roy Bhaskar (2008). Algumas características distintivas da abordagem de Bhaskar são (1998):

i. Uma reivindicação da ontologia, da teoria do ser, como sendo distinta da epistemologia, a teoria do conhecimento, e uma crítica à "falácia epistemológica" que nega esta distinção;

ii. Uma distinção entre os domínios do real, do realizado e do empírico, e uma crítica à redução do real ao realizado no "atualismo" e ao empírico no 
"realismo empírico", junto com uma concepção transfactual e não-empírica da universalidade das leis como poderes causais ou, mais especificamente, como tendências de um mecanismo gerativo que pode ser possuído, não-exercido, nãorealizado e realizado independentemente da percepção ou detecção humana.

$\mathrm{Na}$ ontologia de Bhaskar, a realidade é estratificada nos domínios do real, do realizado e do empírico (Figura 1). A base real das leis causais é fornecida pelos mecanismos gerativos da natureza. Tais mecanismos gerativos são nada mais do que as formas de agir das coisas. E as leis causais devem ser analisadas como suas tendências. As tendências podem ser consideradas como poderes de uma coisa, que podem ser exercidos sem se manifestar em qualquer resultado particular.

Figura 1 - Realidade estratificada em domínios

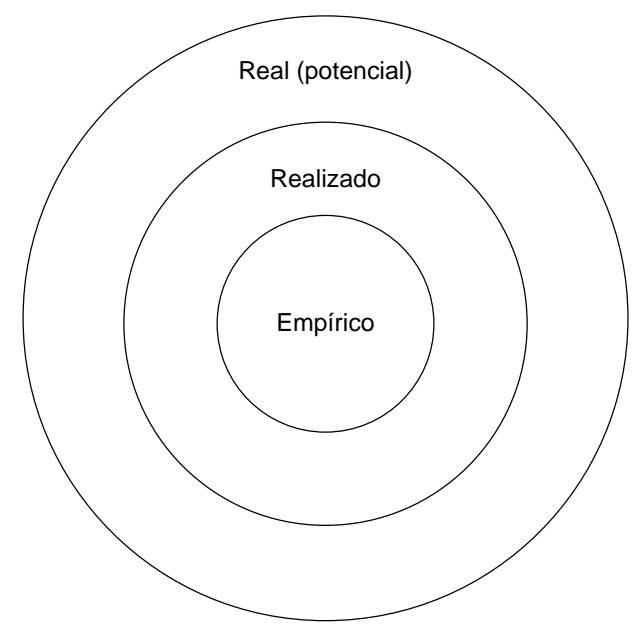

Fonte: (BHASKAR, 2008, p. 14).

Tabela 1 - Estratificação da realidade

\begin{tabular}{|l|c|c|c|}
\hline & Domínio do Real & Domínio do Realizado & Domínio do Empírico \\
\hline Mecanismos & $\checkmark$ & & \\
\hline Eventos & $\checkmark$ & $\checkmark$ & \\
\hline Experiências & $\checkmark$ & $\checkmark$ & $\checkmark$ \\
\hline
\end{tabular}

Fonte: (BHASKAR, 2008, p. 13). 
O domínio empírico consiste naquilo que experimentamos, direta ou indiretamente. Este domínio é parte do domínio do realizado onde os eventos acontecem - quer os experimentemos ou não. $\mathrm{O}$ que acontece no mundo não é igual ao que se observa. $\mathrm{O}$ domínio do realizado, por sua vez, é diferente do domínio do real, onde encontramos as forças e mecanismos que podem produzir eventos no mundo.

O domínio empírico, que em contextos científicos contém nossos "dados" ou "fatos", é sempre impregnado ou enviesado pela teoria. Todos os nossos dados surgem em conexão com alguma teoria e, portanto, nós não experimentamos os eventos de maneira direta como afirma a tradição empiricista. Os dados são sempre mediados por nossas concepções teóricas. A expressão "o mundo empírico", bastante comum, é, portanto, essencialmente equivocada. Ela representa o que Bhaskar denomina de "falácia epistêmica", porque reduz os três domínios a um único domínio; reduz o que é ao que podemos conhecer. $\mathrm{O}$ trabalho científico, todavia, consiste em investigar e identificar as relações e não-relações entre o que experienciamos, o que realmente acontece, e os mecanismos subjacentes que produzem os eventos no mundo.

Bhaskar desenvolve seu Modelo Transformacional da Atividade Social (Transformational Model of Social Activity - TMSA), que implica numa concepção relacional do tema da ciência social. Nesta concepção, a sociedade não consiste de indivíduos, mas expressa a soma das relações dentro das quais se encontram os indivíduos. Os agentes envolvidos podem ou não estar conscientes da existência de tais relações.

Costuma-se traçar uma divisão entre dois campos na teoria sociológica: um, representado, sobretudo, por Max Weber, em que os objetos sociais são vistos como o resultado do (ou constituídos por) comportamento humano intencional ou significativo; e outro, representado por Emile Durkheim, no qual os objetos sociais são vistos como possuindo vida própria, externa e coercitiva ao indivíduo (BHASKAR, 1998a). Esses dois estereótipos estão representados na Figura 2. 
Figura 2 - Voluntarismo e reificação

\begin{tabular}{|c|}
\hline Sociedade \\
Indivíduo \\
$\begin{array}{c}\text { Modelo I - Estereótipo Weberiano } \\
\text { "Voluntarismo" }\end{array}$ \\
\hline
\end{tabular}

Fonte: (BHASKAR, 1998a, p. 212).

Bhaskar critica ainda um terceiro modelo que caracteriza a interrelação sociedadeindivíduo como dialética. Segundo esta concepção, a sociedade forma os indivíduos, que por sua vez cria a sociedade, ou seja, a sociedade produz os indivíduos, os quais produzem a sociedade, numa dialética contínua, conforme Figura 3.

Figura 3 - Concepção dialética

Sociedade

Fonte: (BHASKAR, 1998a, p. 213).

Neste modelo, a sociedade é uma objetificação ou uma externalização dos seres humanos. E os seres humanos, por sua vez, a internalização ou a reapropriação da sociedade na consciência. Segundo Bhaskar, "esta concepção do interrelacionamento entre sociedade e indivíduo encoraja, por um lado, um idealismo voluntarista com relação ao nosso entendimento da estrutura social e, por outro lado, um determinismo mecanicista sobre nosso entendimento acerca das pessoas” (BHASKAR, 1998a, p. 214). 
Como alternativa aos modelos até aqui descritos, Bhaskar propõe seu modelo de conexão sociedade-indivíduo da seguinte maneira: as pessoas não criam a sociedade, pois a mesma sempre pré-existe a elas e é uma condição necessária para suas atividades. Em vez disso, a sociedade deve ser considerada como um conjunto de estruturas, práticas e convenções que os indivíduos reproduzem ou transformam, mas que não existiria se assim não procedessem. A sociedade não existe independentemente da atividade humana (o erro da reificação), nem é o produto da mesma (o erro do voluntarismo) (BHASKAR, 1998a, p. 216). O modelo proposto por Bhaskar pode ser representado pela Figura 4.

Figura 4 - Modelo Transformacional da Atividade Social

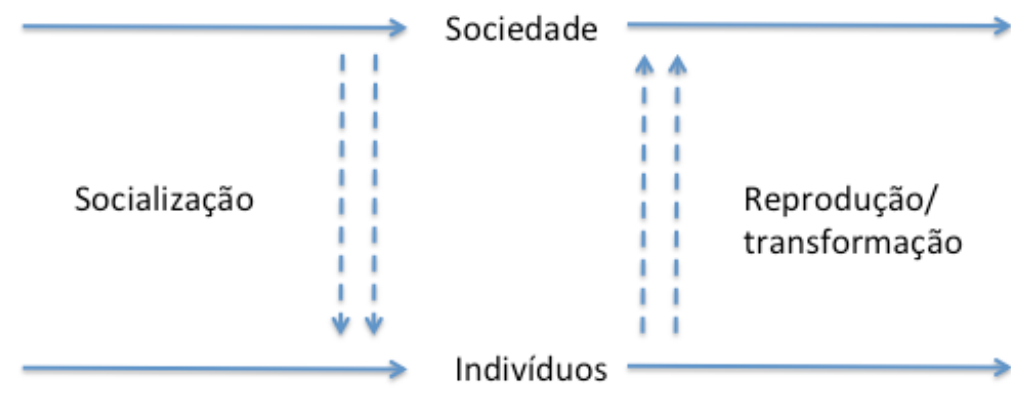

Fonte: (BHASKAR, 1998a, p. 217).

A sociedade fornece as condições necessárias para a ação humana intencional e esta última é uma condição necessária para a sociedade. A sociedade somente está presente na ação humana, mas a ação humana sempre expressa e utiliza uma ou outra forma social. Nenhuma das duas, porém, pode ser identificada ou reduzida a partir da outra. Existe, por assim dizer, um hiato ontológico entre sociedade e indivíduos.

Para que as ciências sociais possam contribuir para o planejamento e a prática social, faz-se necessário conhecer o que molda a vida social. A sociedade consiste de dois fenômenos distintos, os quais são, no entanto, relacionados entre si: pessoas que agem e estruturas sociais. Para o desenvolvimento da teoria social, é fundamental a maneira como a relação entre eles é conceitualizada. Uma estrutura é composta por um conjunto de objetos internamente relacionados. Uma estrutura em particular, por sua vez, pode também ser parte de uma estrutura maior. O mercado de trabalho, casamento e uma equipe de 
trabalho são exemplos de estruturas sociais. As estruturas sociais surgem a partir da agência humana e recebem novas propriedades que lhe são próprias, diferentes das propriedades de pessoas. A análise de uma estrutura envolve o mapeamento, por meio de abstração, das relações que a compõe.

A presente pesquisa parte da idéia básica do realismo crítico de que a realidade social é estratificada nos domínios do empírico, do realizado e do real. Através do mecanismo básico da abstração - que separa ou isola um aspecto particular de um objeto concreto - pretende-se acessar o domínio do real para o fenômeno da participação sociodigital em suas conexões com o desenvolvimento humano, a partir da análise de dados e informações coletados no domínio do empírico, com o objetivo de mapear e caracterizar a relação entre estrutura e agência humana, identificando eventuais mecanismos gerativos que possam explicar a dinâmica da participação política mediada pelas TICs no sistema político da Câmara dos Deputados.

\section{Desenvolvimento e participação política}

O termo "desenvolvimento" vem sendo disputado por várias áreas das ciências sociais - economia, sociologia, ciência política, para citar algumas das principais - e tem sido objeto de estudos por marxistas, institucionalistas, estruturalistas, teóricos da dependência, estudiosos da colonização e da modernidade.

Embora haja certo consenso em torno da noção mínima de que desenvolvimento como um movimento ou processo de transição de um estado ou condição considerada menos vantajosa ou desejada para um estado ou condição percebida por algum conjunto de critérios como mais vantajosa ou desejada, o ponto de maior disputa teórica - e ideológica está na escolha do(s) critério(os), isto é, do(s) “objetivo(s) do desenvolvimento", com base nos quais serão julgadas eventuais melhorias no estado ou na condição de indivíduos ou grupos sociais, ao final do processo de "mudança". 
John Martinussen propõe uma distinção entre conceito (objetivo) de desenvolvimento, teoria de desenvolvimento e estratégia de desenvolvimento (MARTINUSSEN, 1997). Um conceito de desenvolvimento contém a resposta para o que é desenvolvimento. Tal resposta sempre refletirá noções sobre o que dever ser entendido (no sentido normativo) por desenvolvimento. Essas noções podem ser formuladas como objetivos de desenvolvimento, em termos de condições particulares que devem ser alcançadas ou quanto a certa direção de mudança.

Uma teoria do desenvolvimento busca responder a perguntas do tipo: Como os objetivos de desenvolvimento escolhidos e especificados podem ser promovidos? Quais condições podem obstruir, atrasar ou reduzir o progresso em direção aos objetivos? Que relações causais e leis de movimento se aplicam ao processo de mudança social? Que atores exercem papéis dominantes, e que interesses eles têm? De que forma as mudanças afetam vários grupos sociais e várias regiões geográficas?

A estratégia de desenvolvimento refere-se às ações e intervenções que podem ser apropriadamente usadas para promover os objetivos de desenvolvimento. As três distinções sugeridas por Martinussen estão representadas na Figura 5.

Figura 5 - Objetivo (conceito), teoria e estratégia de desenvolvimento

- Hipóteses sobre condições de promoção e obstrução.

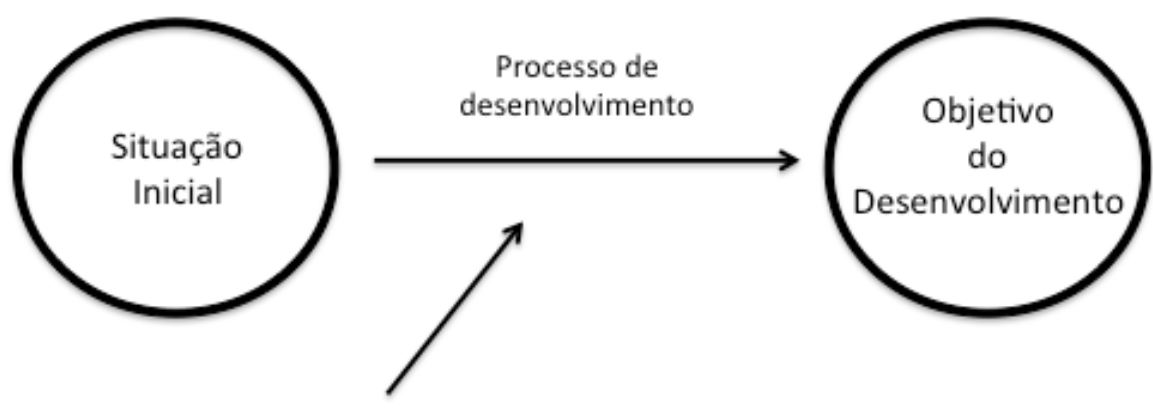

Estratégia de desenvolvimento:

- meios para promover mudanças em direção ao objetivo. 
Fonte: MARTINUSSEN, 1997, p. 15.

Em relação às diversas concepções de desenvolvimento, nas últimas cinco décadas a tendência tem sido em abolir concepções unidimensionais focadas apenas no crescimento econômico e substituí-las por noções multidimensionais que, embora incorporem aspectos econômicos, não se restringem a eles. A persistência da pobreza e o aumento da desigualdade de renda e riqueza em vários países, inclusive naqueles que apresentavam valores elevados e crescentes do seu Produto Interno Bruto (PIB) per capita levaram economistas, cientistas sociais e políticos a questionarem a validade e utilidade de concepções de desenvolvimento baseadas exclusivamente em indicadores macroeconômicos. A questão da distribuição de renda, riqueza e oportunidades se tornou central entre estudiosos do desenvolvimento na década de 1960. A partir daí, surge uma maior preocupação com as condições de vida e o bem-estar de todos os cidadãos de uma sociedade.

\subsection{Desenvolvimento Humano e a Abordagem das Capacidades}

Com a publicação do primeiro Relatório sobre Desenvolvimento Humano (Human Development Report - UDR) em 1990, elaborado sob a liderança de Mahbub ul Haq, economista paquistanês, o Programa das Nações Unidas para o Desenvolvimento (United Nations Development Programme - UNDP) adota a crítica às medidas de renda e apresenta o conceito mais abrangente do desenvolvimento humano (UNDP, 1990).

O primeiro UDR definiu desenvolvimento humano como um processo de ampliação das escolhas dos indivíduos. Inicialmente, a atenção esteve concentrada em termos de escolhas em três áreas essenciais: (1) a oportunidade de levar uma vida longa e saudável; (2) a oportunidade de adquirir conhecimento; e (3) a oportunidade de ter acesso aos recursos necessários para um padrão de vida decente. Posteriormente, foram adicionadas considerações sobre liberdade política e direitos humanos, desenvolvimento humano, para mulheres e para homens (estudos de gênero), meio ambiente e outras questões de sustentabilidade, e temas sobre a participação no sistema político e oportunidades para o cidadão de influenciar as decisões políticas em sociedade. 
Esta última dimensão da escolha - a dimensão política -, atrelada à oportunidade e capacidade do cidadão de influenciar as decisões políticas, estabelece uma conexão entre a temática do desenvolvimento e a questão da participação política, sendo, precisamente, o objeto de investigação da presente tese. Neste sentido, esta pesquisa pode ser entendida como um exercício de teoria do desenvolvimento, sendo um esforço de compreensão das condições de promoção e obstrução do objetivo de ampliar as escolhas das pessoas no campo do político.

A abordagem do Desenvolvimento Humano foi profundamente inspirada pelos trabalhos pioneiros do economista Amartya Sen nas áreas de economia do bem-estar, escolha social, pobreza e fome, e economia do desenvolvimento. A versão da teoria do desenvolvimento humano elaborada por Sen ficou conhecida como Abordagem das Capacidades ou Capability Approach (CA) (SEN, 1999), cujo objetivo consiste em expandir o que as pessoas estão habilitadas a fazer e ser, designadas como suas reais liberdades ou liberdades substantivas. A Abordagem das Capacidades desloca a análise, da economia para a pessoa, e o critério de avaliação, dos recursos econômicos para coisas que as pessoas podem fazer ou ser em suas vidas, agora e no futuro.

A ideia central da Abordagem das Capacidades é a de que arranjos sociais devem estar orientados para a expandir as capacidades das pessoas, isto é, suas liberdades para promover ou alcançar o que valorizam fazer ou ser. Neste sentido, um teste essencial do desenvolvimento é se as pessoas têm maior liberdade hoje do que tinham no passado. Outro conceito associado à idéia de capacidades é a noção de agência. De acordo com Amartya Sen, um agente é "alguém que age e traz mudança" (SEN, 1999, p. 19).

A perspectiva do desenvolvimento humano chama a atenção para o que importa na vida - as pessoas. Ao fazê-lo, a avaliação sobre o valor do próprio crescimento da renda é alterada completamente. O valor limitado da renda e da riqueza tem sido reconhecido há séculos. Aristóteles argumentou que "a riqueza não é evidentemente o bem que procuramos: é algo de útil, nada mais, e ambicionado no interesse de outra coisa" (Ética a Nicômaco, Livro 1).

Um dos objetivos centrais do desenvolvimento humano está em permitir que as pessoas se tornem agentes em suas próprias vidas e em suas comunidades. Como Sen 
argumenta, nas atividades de desenvolvimento "as pessoas têm de ser vistas ... como sendo ativamente envolvidas - dada a oportunidade - na construção do seu próprio destino, e não apenas recipientes passivos dos frutos de astutos programas de desenvolvimento" (SEN, 1999, p. 53). A partir desta perspectiva, o desenvolvimento está baseado na liberdade das pessoas de tomar decisões e promover objetivos-chave. Quando as pessoas e os grupos sociais são reconhecidos como agentes, eles são capazes de definir suas prioridades, bem como escolher os melhores meios para alcançá-las.

As formulações de capacidades na abordagem desenvolvida por Sen possuem duas partes: funcionamentos e liberdade de oportunidade. Os funcionamentos dizem respeito ao ser ou fazer que as pessoas valorizam e têm razões para valorizar. Em outras palavras, funcionamentos são atividades e estados valiosos que compõem o bem-estar das pessoas tais como ser saudável e bem nutrido, estar seguro, ser educado e ter um bom emprego. Os funcionamentos também estão relacionados a bens e renda, mas descrevem o que as pessoas são capazes de fazer ou ser com tais recursos. Por exemplo, quando a necessidade básica das pessoas por alimentos (uma commodity) é atendida, elas desfrutam o funcionamento de "ser bem nutrido".

Capacidades, por sua vez, é a liberdade de desfrutar funcionamentos valiosos. Combinam funcionamentos com um tipo de liberdade de oportunidade. Assim como uma pessoa com um bolso cheio de moedas pode comprar muitas combinações de coisas diferentes, uma pessoa com muitas capacidades pode eleger entre muitos funcionamentos distintos e buscar uma variedade de diferentes caminhos de vida. Por esta razão, o conjunto de capacidades tem sido comparado a um orçamento. As capacidades são, assim, descritas como as atuais e reais possibilidades abertas a uma dada pessoa.

Uma das críticas à Abordagem das Capacidades associa a proposta de Sen a um individualismo de cunho liberal. Segundo esse argumento, a abordagem é "individualista" e, portanto, uma perspectiva liberal, ocidental, que presume que as pessoas agem sozinhas e não como membros de grupos sociais. Para esclarecer em que sentido a abordagem das capacidades foca apenas sobre indivíduos, Ingrid Robeyns distingue três tipos de individualismo, sendo apenas o primeiro promovido pelo enfoque das capacidades (ROBEYNS, 2005, p. 107; 2008, p. 90): 
- $\quad \mathrm{O}$ individualismo ético "postula que os indivíduos, e apenas os indivíduos, são as unidades últimas da preocupação moral ... Isso, é claro, não significa que não devamos avaliar as estruturas sociais e as propriedades sociais, mas o individualismo ético implica que essas estruturas e instituições serão avaliadas em virtude da importância causal que elas têm para o bem-estar individual".

- $\quad \mathrm{O}$ individualismo ontológico sustenta que "a sociedade é construída apenas de indivíduos e nada além de indivíduos e, portanto, não é nada mais do que a soma dos indivíduos e suas propriedades".

- $\quad \mathrm{O}$ individualismo explanatório ou metodológico pressupõe "que todos os fenômenos sociais podem ser explicados em termos dos indivíduos e suas propriedades".

A presunção de que a abordagem das capacidades é individualista baseia-se no fato de que seu foco é sobre o que pessoas individuais (e não grupos) podem fazer e ser. Contudo, deve-se destacar que muito do trabalho na perspectiva das capacidades, e do desenvolvimento humano em geral, tem se dedicado particularmente a grupos - grupos de mulheres, movimentos sociais, ações públicas, práticas democráticas e assim por diante.

A abordagem das capacidades, portanto, não defende um individualismo metodológico ou ontológico. Porém, mesmo quando estamos interessados em grupos, a abordagem das capacidades assume a posição normativa do "individualismo ético" - a visão de que o que importa, em última instância, é o que acontece com cada indivíduo em uma sociedade.

Quando a menor unidade fundamental para a preocupação moral é um grupo, como a família, o grupo social ou a comunidade, existe o risco da análise ignorar sistematicamente quaisquer desigualdades existentes ou potenciais dentro dessas unidades. Por exemplo, as privações específicas para mulheres e crianças têm sido regularmente negligenciadas por análises que focam na família. Somente quando avaliamos o bem-estar de cada pessoa é que temos a possibilidade de identificar a desnutrição relativa, ou subordinação, das mulheres. Esta é, em resumo, a motivação para a promoção do individualismo ético. 
O foco na ampliação das liberdades mostra-se importante porque a expansão de funcionamentos, por si só, poderia ser feita por meio da força, coerção, dominação ou colonialismo. A maioria das necessidades básicas podem ser atendidas em uma prisão, por exemplo. De fato, alguns países usaram a força para promover funcionamentos: por exemplo, a esterilização ou o isolamento forçado de pessoas que são soropositivos em HIV. O foco na liberdade tem a vantagem de chamar a atenção para o desenvolvimento social e o valor do empoderamento, da responsabilidade e da ação pública informada (ALKIRE; DENEULIN, 2009).

Amartya Sen define liberdade como "a real oportunidade que temos para realizar o que valorizamos" (1992, p. 31). A liberdade tem dois aspectos: oportunidade e processo. O aspecto da oportunidade atenta "para a capacidade de uma pessoa em conseguir as coisas que tem razão para valorizar", e o aspecto do processo ressalta a "liberdade envolvida no processo em si” (2002, p. 10). A noção de capacidade refere-se ao aspecto de oportunidade da liberdade, enquanto a noção de agência tem a ver com o processo pessoal de liberdade.

Se por um lado, o foco na liberdade dos indivíduos tem a vantagem de ampliar o espaço informacional dos objetivos de desenvolvimento, por outro, a Abordagem das Capacidades é de difícil operacionalização quando se pretende medir algo abstrato como liberdade. Dentre as várias tentativas de operacionalizar a Abordagem das Capacidades, a pesquisa foca na proposta conhecida como Choice Framework - apresentada na próxima seção -, sugerida por Dorothea Kleine (KLEINE, 2013), que modela os resultados do desenvolvimento como resultantes da interação dinâmica entre estrutura social e agência.

\subsection{Tecnologias da escolha: Choice Framework}

A abordagem conhecida como Choice Framework (CF) consiste numa tentativa de tradução da Abordagem das Capacidades desenvolvida por Amartya Sen (SEN, 2009) em um instrumento para análises sistêmicas no campo das TICs para o Desenvolvimento (Information and Communication Technologies for Development - ICT4D). 
A abordagem CF adota uma visão do desenvolvimento como um processo sistêmico centrado no conceito de escolha. A perspectiva pode ser caracterizada como centrada em pessoas, focada em escolha, holística e sistêmica. Partindo do indivíduo, busca mapear os diferentes elementos do processo de desenvolvimento para então tentar compreender este processo como um sistema. A perspectiva $\mathrm{CF}$ é uma tentativa de utilização da Abordagem das Capacidades de forma ontológica, sem a pretensão de desenvolver uma ferramenta metodológica diretamente aplicável à análise.

O entendimento de capacidades na abordagem $\mathrm{CF}$ inclui formas de ser ou fazer que as pessoas aspiram, sejam alcançáveis ou não. A abordagem faz um mapeamento dos processos de como os indivíduos podem, com o auxílio de seus portfólios de recursos, negociar uma estrutura social para alcançar, por meio de suas escolhas, os resultados de desenvolvimento que aspiram.

A figura a seguir representa os principais elementos da abordagem Choice Framework.

Figura 6 - Choice Framework

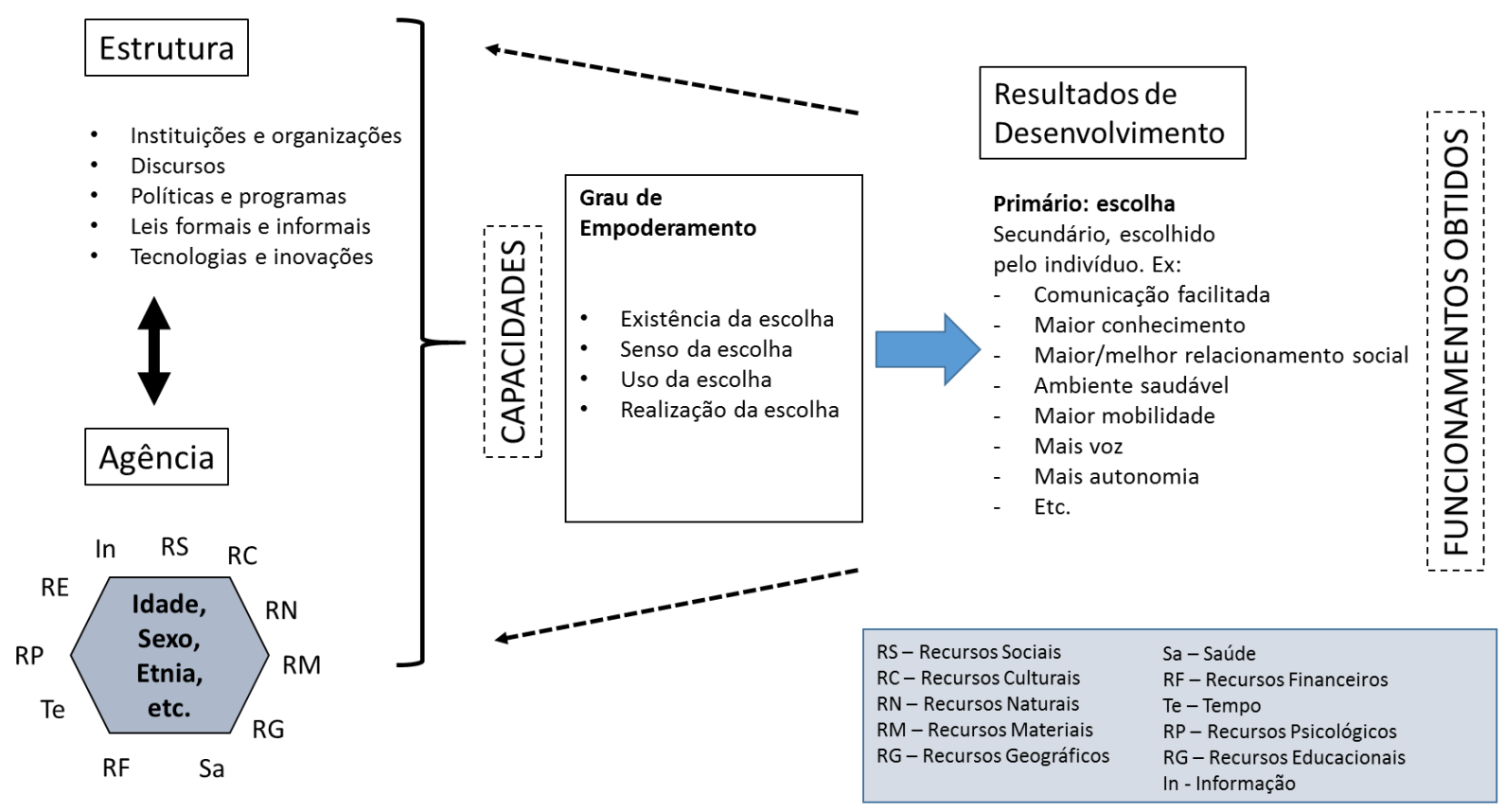

Fonte: (KLEINE, 2013, p. 44). 
Os principais elementos do modelo CF são Estrutura, Agência, Capacidades (Grau de Empoderamento) e Funcionamentos (Resultados de Desenvolvimento). Empoderamento é aqui vinculado ao reforço da capacidade de um indivíduo ou grupo de fazer escolhas eficazes e traduzir essas escolhas em ações e resultados desejados (ALSOP; HEINSOHN, 2005).

Alsop e Heinsohn entende os ativos materiais e não-materiais, ou recursos, como a base da agência individual que, juntamente com condições estruturais, moldam os processos de empoderamento. A combinação entre ação individual e estrutura de oportunidades determinará o grau de empoderamento do indivíduo para alcançar resultados de desenvolvimento.

Em relação aos possíveis resultados do processo de desenvolvimento, a escolha em si - expansão da liberdade - é um dos resultados, sendo simultaneamente o fim primário e o principal meio para o desenvolvimento. Os resultados secundários dependem da escolha dos indivíduos acerca da vida que valorizam. Podem incluir, por exemplo, capacidades como comunicação facilitada com amigos e parentes, maior conhecimento, maior renda ou economia de tempo.

Em relação ao grau de empoderamento (ou dimensões da escolha), temos primeiramente a existência de escolha - se existem diferentes possibilidades e se são, em princípio, alcançáveis para o indivíduo, caso a combinação de seu portfólio de recursos e as condições estruturais assim permitam. A segunda dimensão - o senso de escolha - está relacionada à possibilidade de o indivíduo estar consciente de algumas possibilidades que as novas tecnologias oferecem, mas não de outras. A dimensão do uso da escolha refere-se a se ou não um indivíduo faz uma escolha de fato, e a realização da escolha refere-se a se o resultado obtido corresponde à escolha feita. $\mathrm{Na}$ presente pesquisa, as medidas de efetividade da participação sociodigital correspondem à dimensão da realização da escolha na modelo $\mathrm{CF}$.

A correspondência entre as dimensões da escolha no modelo CF e a participação sociodigital na Câmara dos Deputados é aqui estabelecida da seguinte forma: 
- Existência de escolha - Existência de canais de interação da Câmara dos Deputados com a sociedade;

- Senso de escolha - Os cidadãos sabem da existência dos canais digitais de interação da Câmara dos Deputados com a sociedade;

- Uso da escolha - Os cidadãos fazem uso efetivo dos canais digitais disponibilizados;

- Realização da escolha - A participação sociodigital é efetiva.

Com relação à agência, no modelo CF idade, gênero, etnia, etc., são conceituados como características pessoais de um indivíduo que, dado certo contexto social, podem relacionarem-se a eixos de exclusão e influenciar o escopo e a escala do portfólio de recursos. O portfólio de recursos é composto por onze tipos de recursos - materiais, financeiros, naturais, geográficos, humanos, educacionais, psicológicos, informacionais, tempo, culturais e sociais.

O modelo CF considera não apenas a agência individual, mas também as estruturas que podem ampliar ou limitar o poder de agenciamento. Leis, regras, normas e políticas estão embutidas. Desta forma, além dos elementos estruturais como leis formais e informais, costumes, organizações, instituições, o modelo chama nossa atenção para os discursos como aspecto significativo da estrutura.

\subsection{Capacidades centrais}

Há, ainda, uma variante da Abordagem das Capacidades desenvolvida pela filósofa estadunidense Martha Nussbaum em colaboração com Amartya Sen, na qual propõe uma lista de capacidades centrais que podem ser utilizadas como uma fonte de princípios políticos durante uma constituinte ou como uma fonte para interpretar constituições (NUSSBAUM, 2011). A versão da abordagem das capacidades proposta por Nussbaum foca na proteção de áreas da liberdade tão centrais que sua remoção ou negligência 
transformaria a vida em algo que não estaria à altura da dignidade humana. A dimensão política aparece na lista das capacidades centrais como um dos aspectos da capacidade básica de "Controle sobre o ambiente" nos seguintes termos: "ser capaz de participar efetivamente das escolhas políticas que governam a vida de alguém; tendo o direito da participação política, proteção da liberdade de expressão e de associação" (NUSSBAUM, 2011, p. 34).

Sendo uma das capacidades centrais, a capacidade, por parte dos cidadãos, de participar efetivamente das escolhas ou decisões políticas pode ser considerada como uma forma de medir liberdade substantiva ou desenvolvimento, na acepção das abordagens das capacidades e do desenvolvimento humano. O presente estudo, então, propõe investigar a efetividade da participação dos cidadãos brasileiros nas decisões políticas tomadas no âmbito da Câmara dos Deputados, avaliando, para tanto, o comportamento dos parlamentares no período de tempo que inclui a atual e a última legislatura, de janeiro de 2011 a julho de 2015. A efetividade da participação é aqui interpretada como uma medida de desenvolvimento humano calcada na capacidade que o cidadão tem de influenciar, direta ou indiretamente, o processo legislativo de elaboração das leis.

A análise empreendida se detém na avaliação da efetividade da participação política dos cidadãos através dos canais de relacionamento com a sociedade, disponibilizados pela Câmara dos Deputados, que utilizam alguma forma de Tecnologias da Informação e Comunicação (TICs) na interação Parlamento-sociedade, designados no presente estudo de "canais digitais". O canal digital analisado é o portal e-Democracia. Foram utilizados dados do serviço Disque-Câmara, que consiste numa central de atendimento telefônico (Call Center) que recebe chamadas no número 0800619 619, sobre manifestações dos cidadãos para matérias legislativas.

Um ponto central da presente pesquisa é o estudo da relação entre poder econômico e poder político, e eventuais efeitos dessa relação sobre a efetividade da participação dos cidadãos no sistema político da Câmara dos Deputados através dos canais digitais disponibilizados. Por sistema político, entende-se os "campos e agentes profissionais encarregados da atividade crescentemente "profissionalizada" da política" (MAIA; GOMES; MARQUES, 2011, p. 25). 
A questão da participação política está intimamente associada ao tema da representação política. A cientista política Nadia Urbinati da Columbia University realiza um esforço para identificar as condições que fazem da representação democrática um modo de participação política que possa ativar uma variedade de formas de controle e supervisão por parte dos cidadãos. Inicialmente, destaca que "a soberania popular, entendida como um princípio regulador "como se" guiando a ação e o juízo políticos dos cidadãos, é um motor central para a democratização da representação" (URBINATI, 2006, p. 192).

Urbinati atribui aos teóricos da democracia representativa do século XVIII principalmente Thomas Paine e Condorcet - a ideia de representação como um misto de deliberação e voto, autorização formal e influência informal, envolvendo representantes e cidadãos. No lugar de um esquema de delegação da soberania, esses teóricos viam a representação como um processo político que conecta sociedade e instituições. A previsão dos cidadãos poderem influenciar a deliberação aponta para um conceito de representação que pressupõe a participação política, por isso representação como "um modo de participação política” (URBINATI, 2006, p. 191).

A teoria da representação política defendida por Urbinati e de orientação mais democrática é o produto de uma reformulação da ideia de representação, levada a cabo por Hannah Pitkin nos seguintes termos: "a representação aqui significa agir no interesse dos representados, de uma maneira responsiva a eles" (PITKIN, 1967, p. 209).

A introdução da "responsividade" na noção de representação política é condição fundamental para avaliar seu caráter democrático. Pressupõe uma teia de relacionamentos entre Estado e sociedade civil, uma comunicação ativa e permanente entre eles, através da qual se realizaria a prestação de contas e legitimação da representação. A noção de participação está atrelada à ideia de responsividade, se entendemos participação política como qualquer ação - material ou discursiva - em que o cidadão exerça certo grau de influência sobre o sistema político (MONTERO, 2006).

Desta forma, tanto a participação quanto a representação política dependem da responsividade dos representantes aos interesses, preferências e demandas dos representados. Por essa razão é de fundamental importância, no caso analisado da Câmara 
dos Deputados, comparar a responsividade dos parlamentares às demandas e interesses dos cidadãos, manifestos através dos canais digitais, com a responsividade desses mesmos parlamentares às demandas e interesses dos principais doadores de suas campanhas eleitorais, tipicamente grandes empresas representativas de setores da economia (Figura 7).

Figura 7 - Responsividade do sistema político

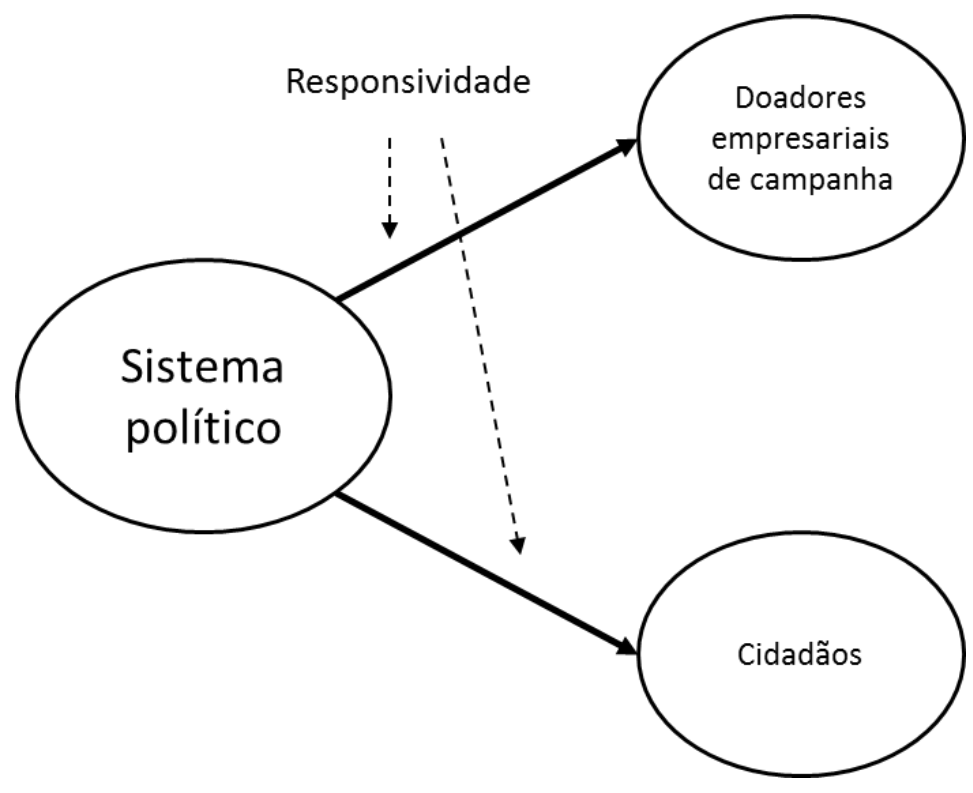

Fonte: elaboração própria.

A efetividade da participação e, por consequência, o desenvolvimento humano, tem a ver com o fato de o sistema político estar inserido em um ecossistema político, com relações recíprocas e geralmente desiguais entre atores pertencentes ao Estado, sociedade civil e mercado (Figura 8).

Tomando como base a Figura 8 , a presente pesquisa se detém no estudo da responsividade política dos deputados federais a partir das relações que os mesmos mantém com atores do mercado (doadores de campanhas eleitorais) e os cidadãos. Analisase a relação entre Parlamento e cidadãos através dos canais digitais interativos institucionalizados e mantidos pela Câmara dos Deputados. 
Figura 8 - Ecossistema Político a partir da Câmara dos Deputados

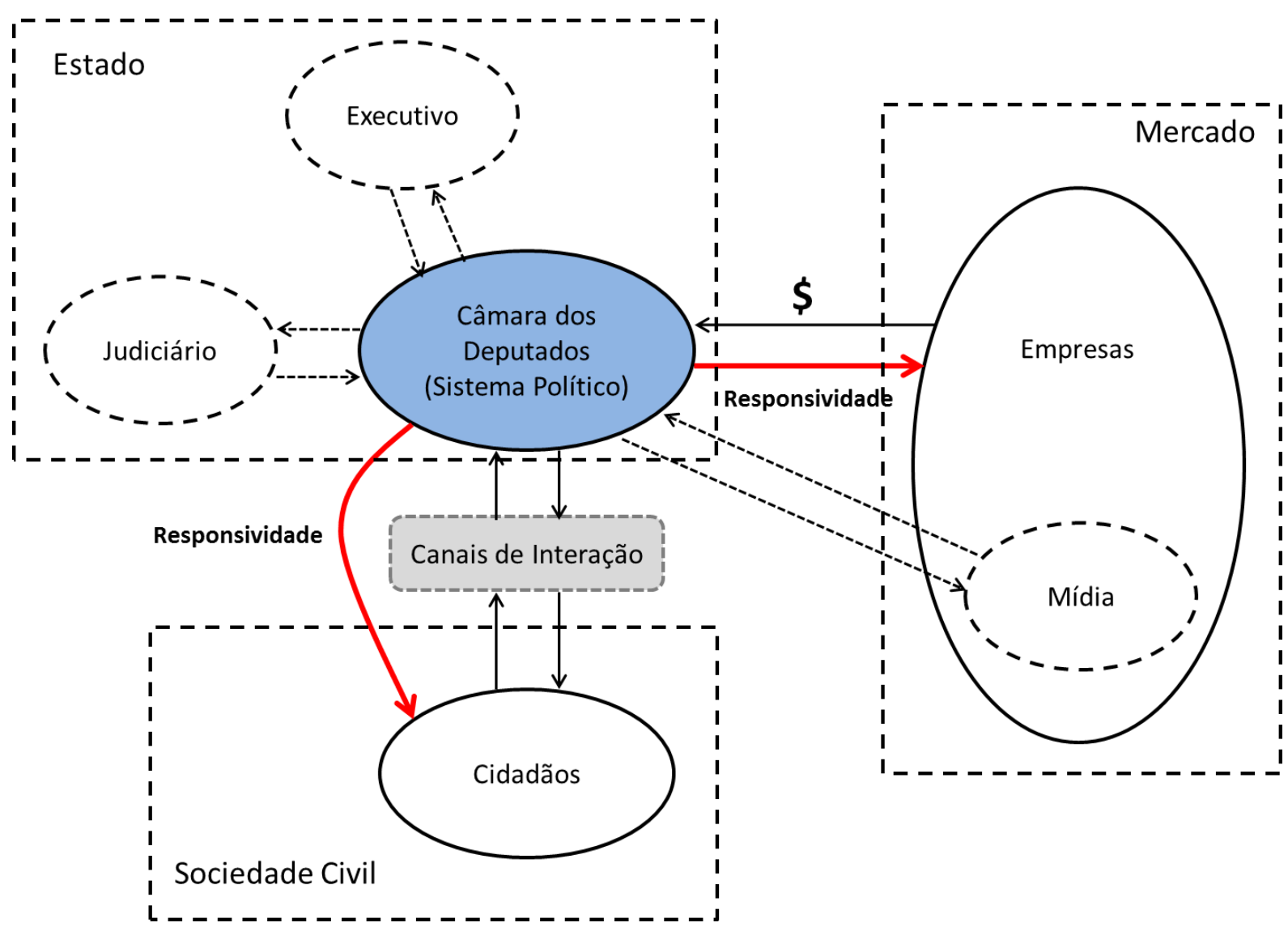

Fonte: elaboração própria.

Existe no capitalismo uma tensão permanente entre mercado e Estado. O capitalismo é um sistema de produção em que os recursos escassos são privadamente apropriados. Contudo, nesse sistema a propriedade é institucionalmente separada da autoridade. Por causa disso, existem dois mecanismos mediante os quais os recursos são alocados para usos diversos e distribuídos para os consumidores: o mercado e o Estado. No mercado, recursos produtivos (capital, terra e capacidade de trabalho) são alocados por seus proprietários e a distribuição do consumo resulta de interações descentralizadas. $\mathrm{O}$ Estado também pode alocar e distribuir, agindo sobre aqueles mesmos recursos que constituem a propriedade privada. A democracia na esfera política exacerba essa tensão. $\mathrm{Na}$ democracia as pessoas, enquanto cidadãos, podem expressar preferências quanto à alocação de recursos que elas não possuem, com direitos distribuídos num contexto de maior igualdade (PRZEWORSKI, 1995). 
Essa "tensão" se manifesta nas relações do sistema político com os demais atores do ecossistema político. O que está em jogo é a possibilidade de influenciar ou mesmo capturar o comportamento dos representantes de tal maneira a controlar o acesso e a alocação do poder político.

Os sistemas políticos estão, portanto, submetidos a pressões de forças políticas, econômicas e sociais que disputam o poder político, buscando capturá-lo e convertê-lo em poder econômico, social, cultural, simbólico, visando satisfazer interesses de grupos ou setores específicos da sociedade. Nestas condições, como avaliar a responsividade e a efetividade da participação dos cidadãos no sistema político? Como fica a soberania popular diante das assimetrias de poder material e simbólico entre atores tão diversos como Parlamento, Executivo, Judiciário, mídia e empresas privadas dos demais setores da economia? Quais as implicações do financiamento empresarial de campanhas eleitorais para a realização da democracia, em especial para a soberania popular, participação política e o desenvolvimento como capacidade de influenciar as decisões políticas?

A presente pesquisa é um esforço no sentido de encontrar possíveis respostas a tais questionamentos. Embora reconhecendo a importância de se considerar as relações do sistema político com todos os atores do ecossistema, o foco deste trabalho está no exame da relação entre sistema político e poder econômico representado pelos interesses de empresas do setor privado, e os potenciais desdobramentos desta relação sobre a capacidade do cidadão de influenciar as decisões políticas tomadas no âmbito da Câmara dos Deputados.

\section{A separação entre o "Político" e o "Econômico"}

Um estudo do desenvolvimento histórico das democracias modernas, realizado por Ellen Wood, conclui que o capitalismo criou uma relação inteiramente nova entre poder político e econômico (WOOD, 2006). O capitalismo teria possibilitado o surgimento de uma democracia limitada, essencialmente "formal" ou processual, em contraposição a noções mais substantivas de democracia. 
Em outro texto, Wood constrói seu principal argumento de que o capitalismo é, em última análise, incompatível com a democracia, se por "democracia" entendermos o poder popular ou autogoverno do povo. O capitalismo seria estruturalmente antitético com relação à democracia, em princípio, pela razão histórica de não ter existido uma sociedade capitalista na qual não se tenha atribuído à riqueza um acesso privilegiado ao poder (WOOD, 2003).

Ao representar o sistema político em conexão com outros sistemas, como o econômico e a sociedade civil, somos obrigados a considerar eventuais assimetrias de poder entre os atores do ecossistema político. Essas assimetrias podem ser traduzidas em diferenças na capacidade de influenciar o processo deliberativo e as decisões dentro do sistema político. Atores com maior poder material e simbólico tendem a desfrutar de acesso privilegiado ao poder político pelos constrangimentos que conseguem impor aos representantes eleitos, eventualmente criando uma condição não-democrática na qual a responsividade do corpo político passa a ser direcionada aos detentores do poder econômico em detrimento de uma responsividade aos cidadãos. Essa distorção pode chegar ao caso extremo da captura do poder político pelo poder econômico.

No campo teórico, depois de Marx, argumenta Wood, houve uma tendência a perpetuar uma rígida separação conceitual entre o "econômico" e o "político" que tão bem atendeu à ideologia capitalista desde que os economistas clássicos descobriram a “economia" na teoria e começaram a esvaziar o capitalismo de conteúdo político e social (WOOD, 2003, p. 27).

O demos, como poder popular, se faz ausente na noção liberal de democracia, que tende a identificá-la com o constitucionalismo, a proteção das liberdades civis e um governo limitado. A ênfase desta concepção de democracia está, não no poder do povo, mas em seus direitos passivos, focalizando meramente o poder político, abstraindo-o das relações sociais, e apelando para um tipo de cidadania passiva. A política seria algo para os representantes eleitos, restando aos indivíduos privados apenas o "julgamento político" no momento do voto.

Wood resgata a idéia Aristotélica de democracia como uma constituição na qual "os nascidos livres e pobres controlam o governo". O critério social joga um papel central 
na noção Aristotélica. De acordo com Wood, "a idéia de que a democracia ateniense consistiu no império de uma classe ociosa que dominava uma população de escravos é sensivelmente equivocada" (WOOD, 2006, p. 398).

Um dos princípios fundamentais da democracia ateniense estava na capacidade e no direito dos trabalhadores e pobres de realizarem juízos políticos e falar sobre eles em assembleias públicas. A palavra para este princípio era "isegoria", que significava "igualdade" e "liberdade" de expressão. A noção de igualdade de expressão, tal como a entendiam os atenienses, se relacionava com o ideal de participação política ativa de pobres e trabalhadores. A isegoria grega pressupunha uma cidadania ativa e igualdade de acesso ao poder político, com a participação de campesinos e outros produtores no poder político. Portanto, a importância da democracia era econômica (e, portanto, social) e política ao mesmo tempo.

Segundo Wood, tudo isso teria mudado com o advento do capitalismo. O poder político e o poder econômico não estariam mais unidos da mesma maneira que estavam previamente. As forças do mercado não estariam mais sujeitas ao controle democrático. Agora, no capitalismo, é possível ter um novo tipo de democracia confinada a uma esfera puramente política e judicial.

Ainda com relação ao desenvolvimento histórico das democracias modernas, Wood observa que os pais fundadores dos Estados Unidos "redefiniram a democracia, ao redefinir seus dois componentes essenciais - o demos ou povo e o kratos ou poder. $\mathrm{O}$ demos perdeu seu significado de classe e se converteu em uma categoria política ao invés de categoria social. O kratos foi compatibilizado com a alienação do poder popular, ou seja, foi convertido no oposto ao que significava para os antigos atenienses" (WOOD, 2006, p. 403). Nas palavras de Ellen Wood,

Numa época de mobilização de massa, o conceito de democracia foi submetido a novas pressões ideológicas pelas classes dominantes, exigindo não somente a alienação do poder "democrático", mas a separação clara entre a "democracia" e o "demos" - ou, no mínimo, o afastamento decidido do poder popular como principal critério de valor democrático. O efeito foi a mudança do foco da "democracia", que passou do exercício ativo do poder popular para o gozo passivo das 
salvaguardas e dos direitos constitucionais e processuais, e do poder coletivo das classes subordinadas para a privacidade e o isolamento do cidadão individual (WOOD, 2033, p. 196).

Luiz Felipe Miguel parece seguir linha de argumentação semelhante à de Wood sobre uma transmutação na noção de democracia, ao afirmar que "a tradução sofrida pela ideia de democracia que deixa de ser o governo do povo para se tornar a competição entre elites, permitiu a apropriação de uma etiqueta valorada de forma positiva por determinados agentes" (MIGUEL, 2014, p. 307). Desses argumentos, depreende-se que o conjunto das desigualdades - sociais, econômicas, de gênero, culturais, etc. - deve ser considerado no esforço de compreensão e crítica das democracias representativas em países capitalistas. Quanto a isso, Miguel observa que

A desigualdade de classe é o primeiro grande eixo de produção de obstáculos ao aprofundamento da democracia. Com o colapso dos projetos alternativos de sociedade, que historicamente tomaram a forma pouco atraente dos regimes de socialismo autoritário, a superação do capitalismo pareceu sair de nosso horizonte de possibilidades. Isso não autoriza, porém, a ignorar os problemas que a ordem capitalista impõe para a efetivação da democracia. A assimetria no controle dos recursos materiais é seu lado mais evidente, dando a alguns a possibilidade de intervir de forma mais eficiente nas disputas políticas (por meio de financiamento de campanhas, da disseminação da informação ou das vantagens advindas da notoriedade que a riqueza produz) e, muitas vezes, relegando outros a situações de privação que tornam a mobilização política um luxo quase inalcançável (MIGUEL, 2014, p. 301).

Miguel destaca o financiamento de campanhas como um dos meios (talvez o principal) pelo qual aqueles com controle sobre recursos materiais (e, pode-se acrescentar, recursos simbólicos) conseguem intervir de forma mais eficiente (e eficaz) nas disputas políticas. O presente trabalho busca analisar a influência do poder econômico sobre o comportamento dos deputados federais na Câmara dos Deputados. O comportamento dos parlamentares será "medido" indiretamente pelo voto nominal de cada deputado sobre matérias legislativas em disputa pelos doadores de campanha e atores da sociedade civil. O voto nominal também será considerado como uma medida indireta da responsividade 
(atenção dispensada) dos deputados aos interesses, em geral concorrentes, dos cidadãos e do mercado.

O presente trabalho parte de um quadro conceitual que pressupõe as lutas concorrenciais pela decisão política. Neste sentido, a participação online teria como objetivo fundamental aumentar o poder da cidadania na comunidade política, ocupando-se em "como garantir e assegurar quotas adequadas de poder político à esfera civil, em face das instâncias que com ela concorrem para influenciar a produção da decisão política e da organização da vida pública" (MAIA; GOMES; MARQUES, 2011, p. 32).

Para Wilson Gomes (MAIA; GOMES; MARQUES, 2011), existem três conjuntos de instâncias concorrentes com o cidadão:

(1) O sistema político, como o domínio social que inclui indivíduos e instituições (hábitos, normas, etc.) dedicados à atividade "política" em sentido estrito, ao funcionamento do Estado e à produção de leis e políticas.

(2) Instâncias situadas em vários campos sociais como a economia ou a religião, com interesses que não raramente se cruzam com as decisões do Estado e com o jogo político. Lutam por influenciar o sistema político e a esfera de decisão política, frequentemente empregando o capital específico do próprio campo (a autoridade religiosa, dinheiro, etc.).

(3) As corporações sociais, instituições da sociedade organizada em torno de uma agenda e de interesses particulares do coletivo que reúnem e representam. Sindicatos e órgãos de classes, parte considerável dos assim chamados movimentos sociais, das ONGs, dos partidos etc., são típicas corporações sociais.

\section{O debate em torno da Democracia Digital}

O campo mais amplo dos estudos sociais da tecnologia, incluindo a Filosofia da Tecnologia, é marcado por um espectro variado de posições sobre o papel da técnica e da tecnologia na vida em sociedade, desde autores portadores de narrativas distópicas em 
relação às possibilidades e benefícios da tecnologia, como Jacques Ellul (1964) e Martin Heidegger (1977), até autores com uma perspectiva bastante otimista, triunfalista em alguns casos, sobre os ganhos e potenciais da tecnologia para o progresso da ciência e a melhoria do bem-estar dos indivíduos. Manuel Castells (1999) e Pierre Levy (2001) são comumente citados como representantes dessa última categoria de autores.

Ao longo da história, poucas tecnologias proporcionaram revolução tão significativa sobre o modo como nos comunicamos, nos informamos, compramos, fazemos guerras e nos divertimos como as Tecnologias da Informação e Comunicação (TICs), desde o telégrafo, passando pelo rádio, a televisão e o telefone, até chegarmos às novas TICs como a comunicação móvel e a Internet. O surgimento e a disseminação dessas novas tecnologias suscitaram inúmeros debates sobre os potenciais e os limites do aperfeiçoamento de práticas democráticas através da telefonia móvel e da Internet. A possibilidade da comunicação instantânea através de grandes distâncias reviveu o sonho de uma democracia direta, com a participação dos cidadãos na deliberação e decisão políticas.

A despeito da grande expectativa sobre o potencial democratizante da Internet, alguns autores preferem uma posição mais cautelosa e crítica sobre as possibilidades dessa tecnologia, considerando que a Internet tem um "potencial vulnerável" de revitalizar os atuais arranjos de comunicação política, injetando novos e diferentes elementos no relacionamento entre representantes e representados, governantes e governados, sendo este potencial, contudo, submetido a um permanente risco de ser desperdiçado sem intervenções políticas criativas desenhadas para moldar e nutrir as oportunidades democráticas fornecidas pela Internet. Em geral, os proponentes dessa perspectiva rejeitam a noção de que a tecnologia é não-social, consistindo em artefatos neutros com capacidades inatas de afetar uma organização social (COLEMAN; BLUMLER, 2009).

Dentre os potenciais democratizantes da Internet, Stephen Coleman e Jay Blumler destacam o fato de ser constituída predominantemente de usuários ativos, a possibilidade de envolver um grande número de usuários numa troca mais ampla de experiências e opiniões sobre algum assunto, o acesso relativamente barato a grandes repositórios de dados, o que pode ajudar a reduzir a influência do status social no envolvimento político. Com a Internet, cidadãos e grupos com poucos recursos podem empreender ações de comunicação e monitoramento que previamente eram o domínio de organizações e 
indivíduos que possuíam recursos suficientes para tanto. Ainda de acordo com Coleman e Blumler, citando Schultz (2000), "a Internet facilita a troca interativa lateral, peer-to-peer, de muitos-para-muitos, permitindo uma maior simetria do poder comunicativo em relação aos fluxos de comunicação unidirecionais da imprensa e do broadcasting" (COLEMAN; BLUMLER, 2009, p. 12).

A aposta está em que as oportunidades únicas criadas pelas tecnologias de comunicação interativa como a Internet possam viabilizar uma representação política e uma governança mais responsiva. Contudo, o sucesso da interatividade e a possibilidade de uma representação mais responsiva não dependem apenas das operações técnicas da Internet, mas de medidas capazes de melhorar a eficácia política. A pergunta-chave para se avaliar projetos e iniciativas de democracia digital (e-democracy) é se existem evidências de que os cidadãos se sentem mais influentes em relação às decisões que governam suas vidas (COLEMAN; BLUMLER, 2009). A designação "democracia digital” refere-se a qualquer forma de emprego de dispositivos (computadores, celulares, smart phones, tablets, etc.), aplicativos (softwares) e ferramentas (fóruns, sítios eletrônicos, redes sociais, mídias sociais, etc.) de tecnologias digitais de comunicação para suplementar, reforçar ou corrigir aspectos das práticas políticas e sociais do Estado e dos cidadãos, em benefício do teor democrático da comunidade política (MAIA; GOMES; MARQUES, 2011).

Para Maia, Gomes e Marques (2011), as iniciativas de democracia digitais democraticamente relevantes seriam aquelas voltadas para um dos seguintes propósitos:

(1) Fortalecimento da capacidade concorrencial da cidadania. Um projeto de democracia digital deve ajudar a promover o aumento e/ou consolidar quotas relevantes do poder do cidadão, em face de outras instâncias concorrentes de disputa pela produção da decisão política no Estado ou na esfera social, a saber, em face das agências políticas (partidos, governo, corporações, etc.) e de outros atores com interesses políticos. Este propósito pode ser dividido em dois objetivos:

a. Aumentar a transparência do Estado e as formas de
responsabilização dos agentes políticos (argumento contra o
patrimonialismo),


b. Participação e influência civis. Tem alto teor democrático iniciativas digitais destinadas a facilitar o estabelecimento de níveis importantes de influência, exercida pelos cidadãos, sobre a decisão política no interior do Estado, sobre mecanismos e processos por meio dos quais a decisão é tomada, sobre os agentes portadores da função de tomar decisão pública, bem como sobre a implementação dessa decisão em normas, políticas e formas equivalentes.

(2) Consolidar e reforçar uma sociedade de direitos, isto é, uma comunidade política organizada como Estado de Direito (argumento por direitos e liberdades). Neste caso, é preciso assegurar que minorias políticas e grupos e setores mais vulneráveis do corpo social tenham preservado os seus direitos, acesso à justiça e proteção jurídica.

(3) Promover o aumento da diversidade de agentes, de agências e de agendas na esfera pública e nas instâncias de decisão política e aumentar instrumentos, meios e oportunidades para que minorias políticas se representem e sejam representadas na esfera pública e nas instâncias de produção da decisão política (argumento pelo pluralismo e pelo aumento da capacidade concorrencial das minorias).

Há, contudo, um custo para se participar da vida política de uma comunidade. Os custos da participação, em determinados contextos sociais e momentos históricos, podem se revelar significativos em termos de recursos materiais, políticos e cognitivos necessários a uma efetiva participação. É razoável concluir que os cidadãos somente farão uso das instituições participativas disponíveis se os benefícios superarem os custos da participação, sendo as iniciativas digitais, neste caso, vistas como uma oportunidade adequada para atingir fins desejáveis. Não é o caso de supor, todavia, um sujeito completamente racional que realiza um julgamento impecável acerca dos ganhos de sua participação, mas, ao contrário, pessoas visitadas por valores e interesses que condicionam e possibilitam sua decisão de participar. As razões para participar não precisam ser racionais. 


\section{Efetividade da participação política}

Ao se pretender estudar a participação sociodigital de cidadãos brasileiros no sistema político da Câmara dos Deputados, precisamos inquirir sobre a efetividade dessa participação. A partir da conceituação da participação como qualquer ação - material ou discursiva - em que o cidadão exerça certo grau de influência sobre o sistema político, deve ser possível o uso de metodologia que permita tecer conclusões sobre a medida da influência dos cidadãos sobre o processo político.

A efetividade da participação tem sido objeto de estudos no contexto da avaliação das instituições participativas. Por instituições participativas entende-se as formas diferenciadas de incorporação de cidadãos e associações da sociedade civil na deliberação sobre políticas (AVRITZER, 2008).

O primeiro problema em relação à efetividade das instituições participativas, destacado por Leonardo Avritzer, é o contexto da política participativa, pensado como o ambiente econômico, político e social que gera a efetividade (AVRITZER, 2011).

De acordo com Adrián Lavalle (2011), a importância da participação tem sido defendida tanto em termos do seu valor em si, quanto em relação a seus possíveis efeitos ou resultados. Quando considerada valiosa por si mesma, a participação é percebida como expressão dos valores democráticos da autodeterminação e da inclusão. Como autodeterminação, a participação se opõe à heteronomia, isto é, ao governo externo à vontade do cidadão e alheio ao seu consentimento. Como inclusão, a participação se vincula a um princípio plebeísta em oposição ao governo de poucos. O ideal plebeísta pode ser formulado da seguinte maneira: todos aqueles que estão sob a autoridade de uma agência que lhes dita decisões compulsórias têm o direito de participar dessas decisões.

Uma segunda forma de avaliar a participação é, continua Lavalle, aferir seus eventuais efeitos ou resultados. Conquanto os efeitos imputados à participação sejam variados, pode-se agrupá-los em três conjuntos:

(1) Efeitos de socialização e psicológicos sobre os participantes; 
(2) Efeitos distributivos;

(3) Efeitos indiretos ou não intencionais.

Dentre os efeitos de socialização e psicológicos, enumeram-se o (1) cultivo do civismo, quando a participação funcionaria como uma "escola da cidadania", (2) incrementos na autoconfiança ou na autopercepção do senso de eficácia do cidadão, e (3) incrementos no senso de pertencimento do cidadão à sua sociedade, o que contribuiria para a formação de identidades políticas amplas e a legitimação das instituições políticas.

Quanto aos efeitos distributivos, seriam gerados quando a participação fosse realizada no marco de instituições incumbidas de orientar as políticas e as prioridades do gasto público.

Já os efeitos indiretos ou não intencionais seriam externalidades positivas capazes de gerar um bem público, como a produção de capital social, entendido como bem coletivo. A participação "incrementaria os estoques de confiança disponíveis em uma determinada coletividade, viabilizando a cooperação e a criação de respostas coletivas a problemas comuns. E por motivos similares, fortaleceria as associações ou a sociedade civil e, embora por caminhos pouco especificados, estimularia o bom governo" (LAVALLE, 2011, p. 38). Os vários tipos de efeitos estão representados na Figura 9. 
Figura 9 - Formas de avaliação da participação

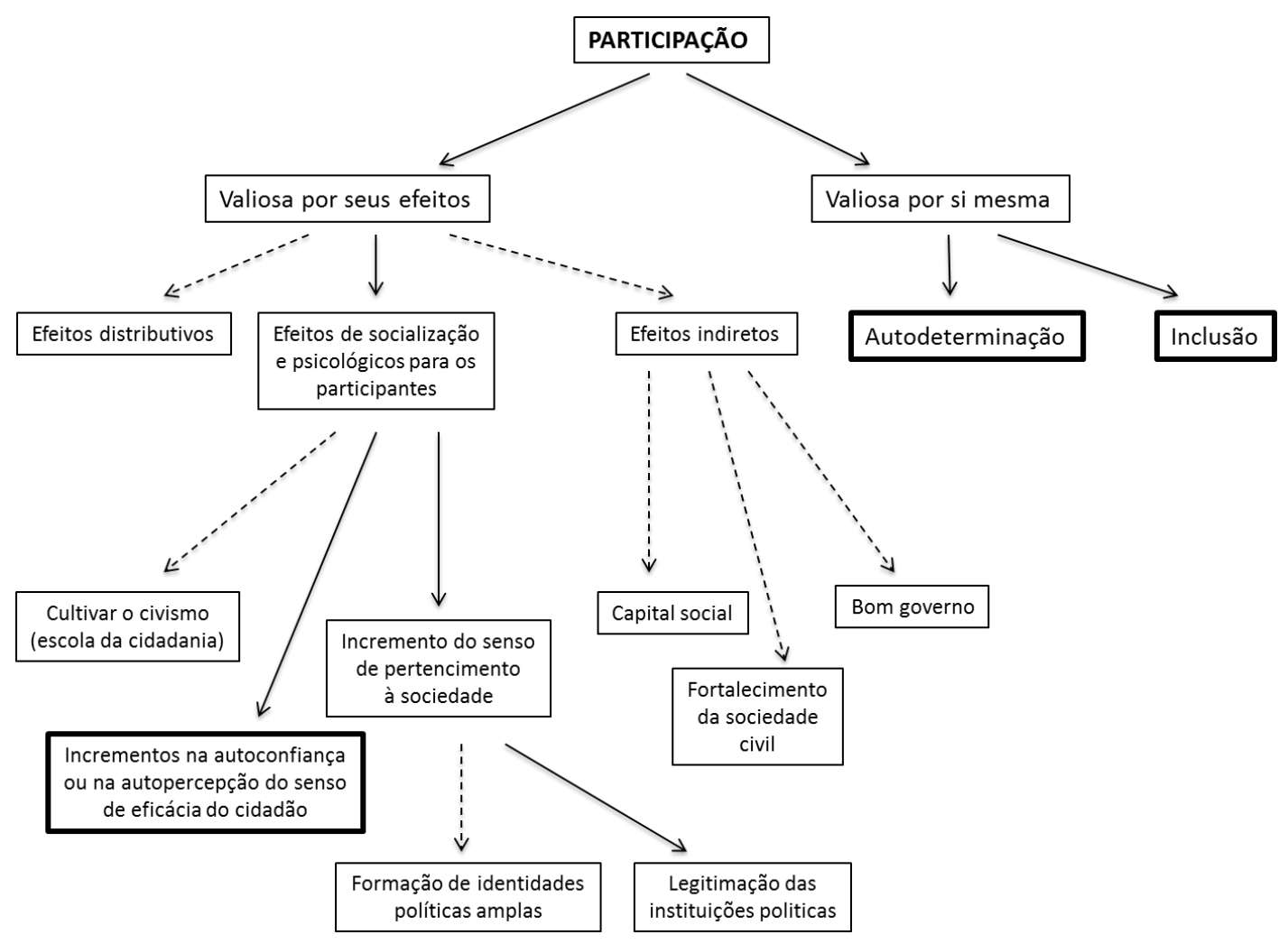

Fonte: elaboração própria, com base na tipologia proposta por Adrián Lavalle.

Embora Lavalle destaque que a participação como valor em si (sentido conotativo) a rigor não seja passível de pesquisa empírica na medida em que seus componentes não são variáveis mensuráveis, em última análise, quando afirmamos que a participação tem um valor intrínseco, na verdade sempre associamos este valor "intrínseco" a valores que tendem a ser reforçados e promovidos, essencialmente a autodeterminação e a inclusão, pela própria existência da participação. Portanto, seria possível descobrir efeitos, percebidos por certas dimensões subjetivas, que possam servir de medida indireta da promoção desses valores.

Com relação à dimensão da inclusão, busca-se responder à seguinte pergunta: a participação na organização sob escrutínio satisfaz ao critério de inclusão ou é ela seletiva (por exemplo, em termos de gênero, faixa etária, nível de instrução formal)? Há duas razões principais para uma representação desigual: nem todos os grupos que se consideram ter interesse legítimo em ser representados na tomada de decisões tem recursos suficientes para se fazer "ouvir", ou nem todos os grupos desfrutam da credibilidade necessária para 
que seus interesses sejam considerados legítimos pelos projetistas institucionais e formuladores de políticas (PAPADOPOULOS; WARIN, 2007).

Em termos de recursos necessários para se fazer "ouvir" na instituição participativa, pode-se elencar recursos materiais como renda, educacionais como educação formal e letramento digital, recursos psicológicos, emocionais e cognitivos. A carência desses recursos pode produzir uma subrepresentação ou mesmo a exclusão completa de alguns cidadãos do processo de participação.

No caso das instituições participativas que utilizam a Internet como meio para a interação com a sociedade, caso dos canais digitais da Câmara dos Deputados, dificuldades de acesso à infraestrutura de comunicação da Internet e a recursos computacionais como computador e dispositivos móveis, em função de baixa renda familiar e/ou por residir em regiões remotas do território nacional, mal servidas em termos de serviços de conectividade à Internet, com conexões intermitentes e de baixa capacidade de transmissão de dados, estão na raiz do fenômeno da exclusão digital, e podem significar enormes barreiras a uma efetiva participação de cidadãos submetidos a tais condições adversas.

A exclusão digital é um fenômeno complexo e multicausal. Fatores como a idade normalmente criam um gap geracional que tende a dificultar ou impedir os idosos - que em geral têm maior dificuldade em manejar de forma adequada as novas ferramentas digitais-, de participar da Sociedade em Rede. Num cenário de democracia digital, onde a participação política está cada vez mais mediada por plataformas comunicacionais como a Internet e a telefonia móvel, a exclusão digital pode significar a impossibilidade do exercício da cidadania para segmentos da população.

Qualquer reflexão sobre os obstáculos à participação de segmentos menos favorecidos da sociedade tem que incluir o questionamento sobre (des)incentivos daqueles favorecidos pelo status quo para se envolver em trocas deliberativas e incluir novas questões na agenda política. Tal questionamento faz sentido quando se espera que processos participativos possam exercer alguma influência na tomada de decisão, desafiando, assim, o poder de influência de outros canais onde atores poderosos são mais fortes (PAPADOPOULOS; WARIN, 2007). 
Este é, precisamente, o caso da Câmara dos Deputados, onde, por um lado, existem os canais digitais de participação desenhados e disponibilizados pela Câmara para a interação dos parlamentares com a sociedade e, por outro, canais informais, geralmente opacos, de interação entre os parlamentares e agentes econômicos, na maioria doadores de campanhas eleitorais, através dos quais o poder econômico exerce, supostamente, forte influência no comportamento dos deputados.

Essa assimetria de poder pode levar a uma assimetria equivalente na responsividade do corpo político em relação aos interesses gerais dos cidadãos e os interesses particulares dos doadores de campanha. Dado que a chance de ser eleito ou reeleito é função direta do gasto em campanha (MANCUSO; FILHO, 2014), é muito provável que existam grandes incentivos para que os deputados sejam mais responsivos - concedam maior atenção e prioridade - aos interesses dos doadores de campanha, se comparado à responsividade dispensada ao cidadão comum que busca interagir com os parlamentares através dos canais de participação disponibilizados pela instituição.

A assimetria na responsividade pode ser um dos fatores explicativos para uma baixa efetividade da participação dos cidadãos no sistema político, sendo traduzida numa fraca influência nas decisões políticas expressas, principalmente, pelo voto nominal dos parlamentares sobre matérias relevantes e de interesse dos cidadãos. Esta é uma das suspeitas da presente pesquisa.

Outro conjunto de critérios de avaliação da participação é proposto por Gene Rowe e Lynn Frewer (2000), e resumidos na Tabela 2, a seguir. 
Tabela 2 - Critérios de avaliação da participação

\begin{tabular}{|l|l|}
\hline \multicolumn{1}{|c|}{ Critério } & \multicolumn{1}{c|}{ Definição } \\
\hline Representatividade & $\begin{array}{l}\text { Os participantes em exercício devem incluir } \\
\text { uma amostra bastante representativa da } \\
\text { população afetada }\end{array}$ \\
\hline Independência & $\begin{array}{l}\text { O processo de participação deve ser conduzido } \\
\text { de forma independente (não enviesado) }\end{array}$ \\
\hline Envolvimento precoce & $\begin{array}{l}\text { Os participantes devem ser envolvidos tão } \\
\text { cedo quanto possível no processo, tão logo } \\
\text { julgamentos de valor se tornem salientes ou } \\
\text { relevantes }\end{array}$ \\
\hline Influência & $\begin{array}{l}\text { O resultado do processo de participação deve } \\
\text { ter um impacto genuíno na política }\end{array}$ \\
\hline Transparência & $\begin{array}{l}\text { O processo deve ser transparente para que a } \\
\text { população relevante possa ver o que está } \\
\text { acontecendo e como as decisões estão sendo } \\
\text { tomadas }\end{array}$ \\
\hline Relação custo-eficácia & $\begin{array}{l}\text { Os participantes devem ter acesso aos recursos } \\
\text { apropriados que os habilitem a cumprir } \\
\text { plenamente suas funções }\end{array}$ \\
\hline Acessibilidade a recursos & $\begin{array}{l}\text { A natureza e o escopo da tarefa de } \\
\text { participação deve ser claramente definida }\end{array}$ \\
\hline Definição de tarefa & $\begin{array}{l}\text { O exercício da participação deve usar ou prover } \\
\text { mecanismos apropriados para estruturação e } \\
\text { exibição da tomada de decisão }\end{array}$ \\
\hline $\begin{array}{l}\text { O procedimento de participação deve de } \\
\text { alguma forma ser custo-efetivo do ponto de } \\
\text { vista dos patrocinadores }\end{array}$ \\
\hline
\end{tabular}

Fonte: (ROWE; FREWER, 2000).

Combinando os critérios de avaliação da participação sugeridos por Lavalle e Rowe e Frewer, a presente pesquisa busca analisar a efetividade da participação sociodigital na Câmara dos Deputados por meio dos seguintes critérios:

- Influência e responsividade:

- Influência dos cidadãos sobre as decisões políticas e responsividade dos deputados.

- Efeitos de socialização e psicológicos:

○ Autopercepção do cidadão sobre sua capacidade de agir (senso de eficácia da participação);

○ Percepção do cidadão em relação à responsividade dos parlamentares às suas manifestações no portal e-Democracia.

- Inclusão: 
- Avaliação do perfil sociodemográfico dos participantes do portal eDemocracia.

A dimensão da influência busca avaliar o poder relativo do cidadão em fazer prevalecer sua opinião e sua vontade face às instâncias que com ele concorrem na determinação da decisão política no Estado. Neste trabalho, investiga-se esse poder relativo do cidadão frente a uma das principais instâncias concorrentes - o poder econômico.

Na dimensão dos efeitos de socialização e psicológicos, realiza-se um esforço para capturar a percepção dos cidadãos-participantes quanto à efetividade e eficácia da participação popular por meio da principal iniciativa de democracia digital existente na Câmara dos Deputados - o portal e-Democracia -, a fim de confrontar e, eventualmente, superar o desafio, destacado por Adam Przeworski (2010), da histórica incapacidade das democracias contemporâneas em fazer com que as pessoas sintam que sua participação política é efetiva. 


\section{PARTE II - MÉTODOS}

Todo conhecimento é mediado conceitualmente e, portanto, é impossível fazer observações neutras de "fatos" sobre a realidade. O argumento metodológico básico do realismo crítico é que a natureza do objeto de estudo determina que métodos de pesquisa serão considerados adequados e que tipo de conhecimento será possível adquirir dos diferentes fenômenos de interesse.

Para explicar fenômenos do mundo social, não é suficiente fazer observações empíricas, as quais muito raramente conseguem capturar os mecanismos subjacentes que produzem os fenômenos. Os poderes e mecanismos podem estar presentes e trabalhando sem sermos capazes de perceber qualquer ligação imediata entre eles e os efeitos que produzem.

\section{Pluralismo metodológico crítico}

Em termos metodológicos, a presente pesquisa adota uma perspectiva multimétodo conhecida como Pluralismo Metodológico Crítico (PMC) (DANERMARK; EKSTRÖM; JAKOBSEN; KARLSSON, 2002), que considera proveitosa a combinação de métodos na prática de pesquisa, evitando-se, contudo, o equívoco do relativismo metodológico. $\mathrm{Na}$ perspectiva do pluralismo metodológico crítico, o critério do que é adequado ou não em termos de combinação de métodos deve ser encontrado na relação entre meta-teoria e método. A combinação de métodos deve ser governada não somente pela pergunta de pesquisa, mas, e fundamentalmente, pela perspectiva ontológica adotada.

Na perspectiva do PMC, a questão decisiva é como diferentes metodologias podem transmitir conhecimento sobre os mecanismos gerativos. Os mecanismos são considerados como tendências que podem ser reforçadas, modificadas ou suprimidas em uma complexa interação com outros mecanismos em um sistema aberto. $\mathrm{O}$ resultado é que nem sempre 
eles podem manifestar-se empiricamente. Além disso, a motivação para a ação é considerada um mecanismo causal ao lado de outros.

A perspectiva do PMC descreve o processo de pesquisa em termos de procedimentos empíricos intensivos e extensivos. A abordagem intensiva concentra-se em mecanismos gerativos. A maioria dos problemas de ciências sociais são complexos, tornando difícil estudar um grande número de casos, forçando, assim, os pesquisadores a limitarem-se a poucos casos, que são, então, estudados de forma mais intensiva. Investigar como um mecanismo funciona em uma situação concreta envolve traçar o poder causal e descrever a interação entre poderes que produzem um fenômeno social. Enquanto busca-se analisar esses mecanismos, pode-se também ser de interesse descobrir quão comum é um fenômeno, quais são as características de uma população em particular, etc. Estas são algumas das questões focadas pela abordagem extensiva.

A forma como os procedimentos intensivos e extensivos relacionam-se com os métodos qualitativos e quantitativos pode ser descrita da seguinte forma: o procedimento empírico intensivo contém elementos substanciais de coleta e análise de dados de natureza qualitativa. O procedimento extensivo tem a ver com a coleta de dados quantitativos e análise estatística. É importante ter em mente que os diferentes métodos de coleta e análise de dados são definidos em um contexto particular de meta-teoria, a do realismo crítico.

A Tabela 3 a seguir apresenta um quadro comparativo entre os procedimentos empíricos intensivos e extensivos. 
Tabela 3 - Procedimentos intensivos e extensivos

\begin{tabular}{|c|c|c|}
\hline \multirow{2}{*}{\multicolumn{3}{|c|}{$\begin{array}{l}\text { Tarefa: Identificar mecanismos gerativos e } \\
\text { manifestados em eventos e processos reais. } \\
\text { Procedimentos empíricos }\end{array}$}} \\
\hline & & \\
\hline & Intensivo & Extensivo \\
\hline \multirow[t]{2}{*}{$\begin{array}{l}\text { Questão de } \\
\text { pesquisa }\end{array}$} & $\begin{array}{l}\text { Como um processo } \\
\text { trabalha em um caso } \\
\text { particular ou um pequeno } \\
\text { número de casos? }\end{array}$ & $\begin{array}{l}\text { Quais são as regularidades, } \\
\text { padrões comuns e } \\
\text { características distintivas de } \\
\text { uma população? }\end{array}$ \\
\hline & $\begin{array}{l}\text { O que produz certa } \\
\text { mudança? O que os } \\
\text { agentes realmente fazem? }\end{array}$ & $\begin{array}{l}\text { Quão amplamente são certas } \\
\text { características ou processos } \\
\text { distribuídos ou representados? }\end{array}$ \\
\hline Relações & $\begin{array}{l}\text { Relações substanciais de } \\
\text { conexões }\end{array}$ & $\begin{array}{l}\text { Relações formais de } \\
\text { similaridade }\end{array}$ \\
\hline $\begin{array}{l}\text { Tipo de grupo } \\
\text { estudado }\end{array}$ & Grupos causais & Grupos taxonômicos \\
\hline $\begin{array}{l}\text { Métodos } \\
\text { típicos }\end{array}$ & $\begin{array}{l}\text { Estudo de agentes } \\
\text { individuais em seus } \\
\text { contextos causais, } \\
\text { entrevistas interativas, } \\
\text { etnografia, análise } \\
\text { qualitativa. }\end{array}$ & $\begin{array}{l}\text { Surveys em grande escala de } \\
\text { populações ou amostra } \\
\text { representativa, questionários } \\
\text { formais, entrevistas } \\
\text { padronizadas. Análise } \\
\text { estatística. }\end{array}$ \\
\hline Limitações & $\begin{array}{l}\text { Improvável que os padrões } \\
\text { concretos atuais e relações } \\
\text { contingentes sejam } \\
\text { "representativas", } \\
\text { "médias" ou } \\
\text { generalizáveis. }\end{array}$ & $\begin{array}{l}\text { Embora representativa de uma } \\
\text { população inteira, improváveis } \\
\text { de serem generalizáveis para } \\
\text { outras populações em diferentes } \\
\text { momentos e lugares. Problema } \\
\text { da falácia ecológica em } \\
\text { inferências sobre os indivíduos. } \\
\text { Poder explicativo limitado. }\end{array}$ \\
\hline $\begin{array}{l}\text { Tipo de } \\
\text { explicação } \\
\text { produzida }\end{array}$ & $\begin{array}{l}\text { Explicação causal da } \\
\text { produção de certos objetos } \\
\text { ou eventos, embora não } \\
\text { necessariamente } \\
\text { representativa. }\end{array}$ & $\begin{array}{l}\text { Generalizações descritivas } \\
\text { "representativas", sem } \\
\text { penetração explicativa. }\end{array}$ \\
\hline
\end{tabular}

Fonte: (DANERMARK; EKSTRÖM; JAKOBSEN; KARLSSON, 2002, p. 165). 
Os procedimentos intensivos têm seu foco em grupos causais e buscam encontrar relações substantivas, ao passo que os procedimentos extensivos podem identificar apenas relações formais de similaridades. As relações substantivas referem-se a relações factuais interligando, por exemplo, proprietários de terras e arrendatários, marido e esposa, enquanto que uma relação formal é uma relação de semelhanças/dessemelhanças, por exemplo, idade ou renda. Em uma rede social, por exemplo, os indivíduos interagem e estão em uma relação substantiva um com o outro. As relações entre os membros da rede constituem a rede social. Se eles deixam de interagir, a rede deixa de existir. Se olharmos para as relações formais, há uma situação totalmente diferente. Por exemplo, um grupo de pacientes com o mesmo diagnóstico tem a mesma característica (o diagnóstico) e estão formalmente relacionados uns aos outros. No entanto, o grupo de pacientes não é constituído por nenhuma interação social entre os pacientes, mas tão somente porque compartilham uma mesma característica (DANERMARK; EKSTRÖM; JAKOBSEN; KARLSSON, 2002).

Assim, é o tipo de relação que define qual tipo de grupo é estudado, causal ou taxonômico. "Na abordagem intensiva, o foco está em grupos causais. Isto leva-nos a concluir que nas abordagens metodológicas extensivas, onde grupos taxonômicos são usados como material empírico, dificilmente encontraremos relações substantivas" (DANERMARK; EKSTRÖM; JAKOBSEN; KARLSSON, 2002, p. 168).

As abordagens - intensiva ou extensiva - produzem resultados distintos. A diferença fundamental é que através da abordagem intensiva é possível expor os mecanismos gerativos. Em um projeto extensivo pode-se, na melhor das hipóteses, explicar uma determinada ocorrência ou um particular objeto, ou um fenômeno social maior. "A abordagem extensiva sozinha não pode responder perguntas sobre causalidade. Por outro lado, pode-se apontar manifestações empíricas importantes dos mecanismos. Assim, podese fornecer informação descritiva vital que seja útil como suporte em uma discussão sobre os poderes causais, e pode contribuir para a geração de perguntas sobre causalidade" (DANERMARK; EKSTRÖM; JAKOBSEN; KARLSSON, 2002, p. 175).

Andrew Sayer (1992) sugere uma tipologia para o relacionamento entre diferentes tipos de pesquisa (Figura 10), destacando que, na prática, um projeto pode combinar vários tipos. 
Figura 10 - Tipos de pesquisa

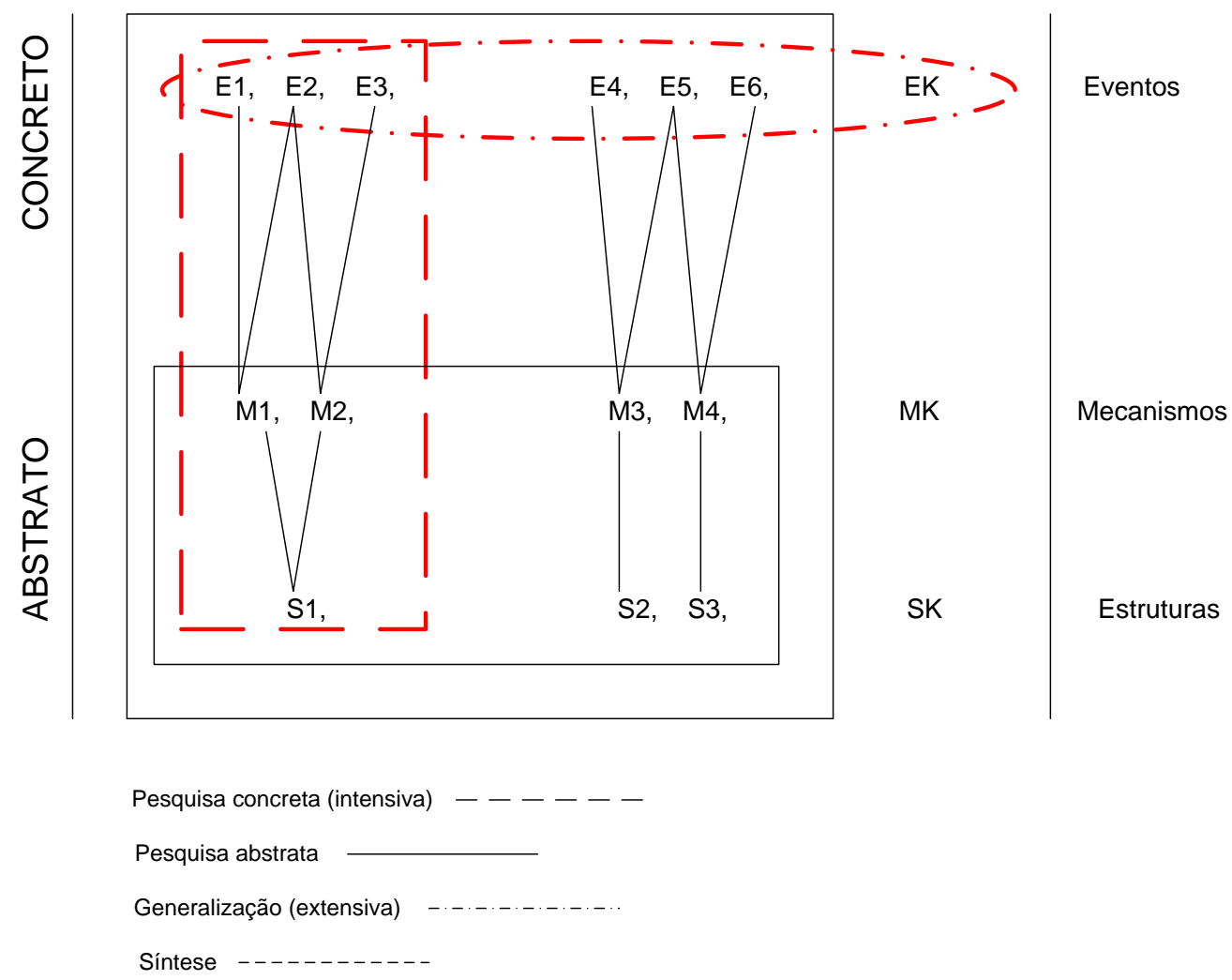

Fonte: (SAYER, 1992, p. 237).

As pesquisas teóricas abstratas lidam com a constituição e possíveis formas de agir dos objetos sociais, e os eventos que ocorrem são tratados apenas como possíveis resultados. Exemplo deste tipo de pesquisa incluem teorias do valor em economia e teorias de classes sociais que definem classe em termos de relações internas. Estudos concretos de pesquisa tratam os eventos e os objetos como "unidades de diferentes determinações", cada um sendo isolado e examinado através de pesquisa abstrata. Por outro lado, o método da generalização tende a não envolver abstração, pelo menos não de forma autoconsciente, e tratam eventos e objetos simplesmente como concretos. Seu propósito principal é procurar por regularidades e propriedades comuns neste nível. Pode-se adicionar um quarto tipo, a "síntese", ou seja, uma pesquisa que tenta explicar as principais partes do sistema combinando descobertas de pesquisa abstratas e concretas com generalização, cobrindo uma ampla gama de estruturas constitutivas, mecanismos e eventos. 
Acontece que as funções desses diferentes tipos de pesquisa costumam não ser bem compreendidas. Frequentemente, os pesquisadores as supervalorizam esperando que um único tipo de pesquisa realize o trabalho de todas as outras.

É neste sentido que a presente pesquisa propõe uma combinação entre pesquisa extensiva (generalização) e intensiva (concreta), conforme destacado na Figura 10, por entender que o objeto de pesquisa a ser investigado é de natureza complexa e multidimensional, envolvendo a necessidade do uso de métodos explicativos no nível do concreto e no nível do abstrato. A pesquisa extensiva é realizada por meio de análise quantitativa, com o uso de métodos estatísticos, da relação entre financiamento empresarial de campanha e comportamento parlamentar em termos de responsividade. A pesquisa intensiva baseia-se em entrevistas com os gestores dos canais digitais de participação popular e aplicação de questionário a cidadãos que interagiram com a Câmara dos Deputados através do portal e-Democracia (Figura 11).

Figura 11 - Pesquisas intensiva e extensiva na presente tese

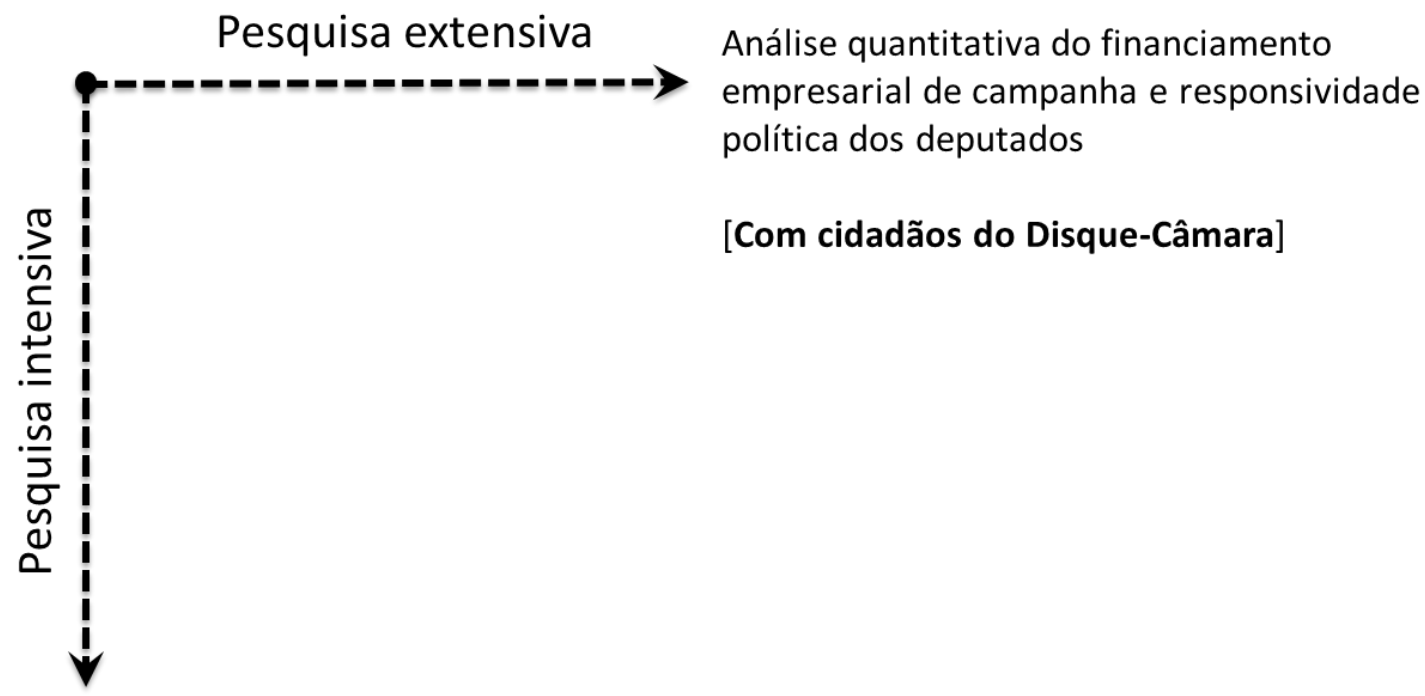

Análise qualitativa - entrevistas

e questionário

[Com cidadãos do e-Democracia)

Fonte: elaboração própria. 


\section{Método Explanatório do Realismo Crítico}

Este capítulo descreve o método explanatório utilizado durante o desenvolvimento da pesquisa. O método está baseado na ontologia do Realismo Crítico.

Um objetivo geral em pesquisas sociais é explicar eventos e processos. A partir da perspectiva do realismo crítico, explicar algo implica primeiro descrever e conceituar as propriedades e os mecanismos causais que geram os eventos e, em seguida, descrever como diferentes mecanismos se manifestam em condições específicas (DANERMARK; EKSTRÖM; JAKOBSEN; KARLSSON, 2002).

\section{Generalizacão}

Dentro da ciência, há duas maneiras distintas de entender a generalidade - o conceito empirista de generalidade e o conceito realista de generalidade. De acordo com o primeiro, generalidade é uma questão de em que medida uma observação empírica pode ser generalizada para um grande grupo de eventos ou fenômenos. Neste caso, a generalização é uma extrapolação. O conhecimento de uma quantidade limitada de eventos é extrapolado para, e considerado válido para, uma população maior.

De acordo com o conceito realista de generalidade, generalizações científicas referem-se, em grande medida, a condições transfactuais, às pré-condições mais ou menos universais para que um objeto seja o que é. Roy Bhaskar expressa da seguinte maneira: "Generalidade cientificamente significativa não se apoia sobre a face do mundo, mas na essência oculta das coisas" (BHASKAR, 2008, p. 217). A Figura 12 ilustra a diferença entre esses dois tipos de generalização. 
Figura 12 - Dois tipos de generalização

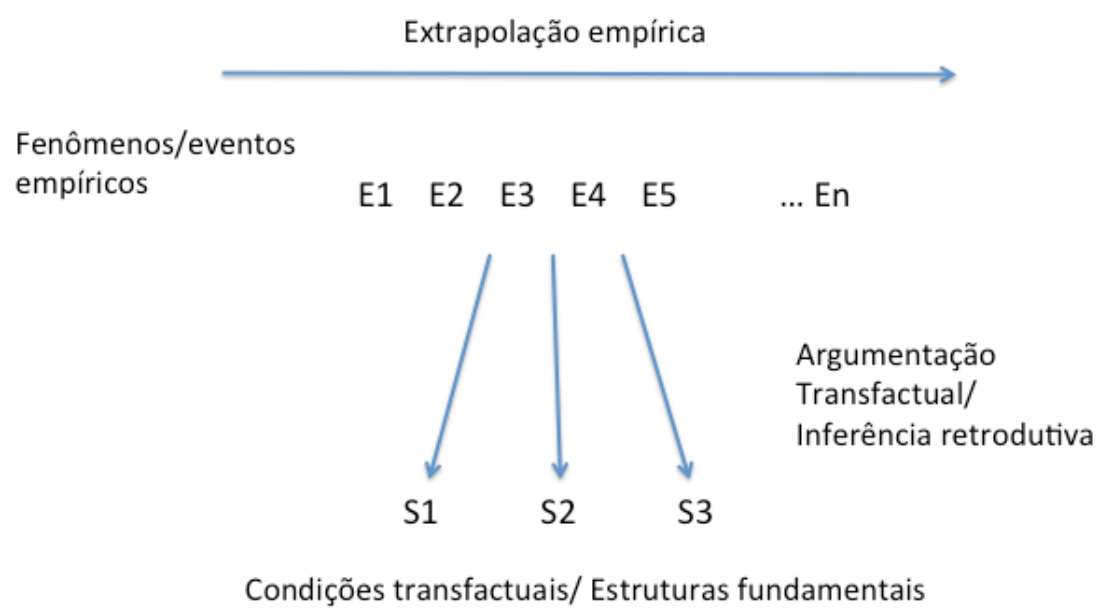

Fonte: (DANERMARK; EKSTRÖM; JAKOBSEN; KARLSSON, 2002, p. 77).

A Figura 12 indica que, em primeiro lugar, algo pode ser geral em dois sentidos diferentes - no sentido de um fenômeno/evento empírico que ocorre de uma maneira geral, ou no sentido de propriedades e estruturas fundamentais/constituintes. Em segundo lugar, que existem diferentes ações, métodos e padrões de inferência por trás dessas generalizações. A extrapolação empírica é baseada na indução. A indução é um processo onde, a partir de observações de um número limitado de eventos ou fenômenos (E1, E2, E3, E4, etc.), são elaboradas conclusões universalmente aplicáveis a uma população maior. Trata-se de tirar conclusões sobre o geral a partir do conhecimento do particular, sem abandonar o nível empírico. Os métodos científicos neste contexto são, por exemplo, técnicas que utilizam amostras representativas e avaliam a certeza estatística de uma generalização.

O conhecimento sobre as propriedades constituintes ou condições transfactuais, por outro lado, é obtido por meio de argumentos transfactuais e inferência retrodutiva, tomando o concreto como ponto de partida, tentando abstrair e isolar o que é constituinte básico. Move-se da superfície para a profundidade, do domínio do empírico para o domínio das estruturas e mecanismos. 
Condições transfactuais "são as condições para que algo - uma relação social, uma ação, uma instituição ou uma estrutura social - possa ser o que é e não algo completamente diferente” (DANERMARK; EKSTRÖM; JAKOBSEN; KARLSSON, 2002, p. 78).

A presente pesquisa parte do conceito realista de generalidade e busca identificar as condições transfactuais que poderiam explicar a dinâmica da participação sociodigital na Câmara dos Deputados e sua relação com o desenvolvimento humano. Utiliza-se de argumentos transfactuais e inferência retrodutiva, partindo-se do domínio do empírico análise de dados sobre financiamento empresarial de campanhas eleitorais e comportamento dos deputados, de entrevistas com gestores dos canais de interação com a sociedade e das respostas de participantes do portal e-Democracia ao questionário - para o domínio das estruturas e mecanismos.

\section{$\underline{\text { Abducão }}$}

Abdução significa passar de uma concepção de algo para outra diferente, possivelmente mais desenvolvida ou mais profunda do mesmo objeto. Isso acontece quando interpretamos as ideias originais sobre um fenômeno a partir de novos quadros de referência ou um novo conjunto de ideias.

Podemos definir abdução também como redescrição ou recontextualização. Recontextualizar significa observar, descrever, interpretar e explicar algo a partir da referência de um novo contexto.

A revolução operada pelas recontextualizações está associada à possibilidade de construção de novos significados para fenômenos já conhecidos. As descobertas das ciências sociais são, em grande medida, associadas à recontextualização. Os cientistas sociais não descobrem eventos novos que ninguém conhecia antes. O que se descobre são conexões e relações, não diretamente observáveis, através das quais podemos entender e explicar de uma nova maneira as ocorrências já conhecidas. Em uma análise científica crítica, é importante empregar a inferência abdutiva para a redescrição, para que se possa interpretar fenômenos particulares como parte de estruturas gerais. 
A abdução é, portanto, um tipo de inferência onde a redescrição ou a recontextualização é o elemento central. Por meio da abdução é possível recontextualizar e reinterpretar algo, entendendo-o dentro de um contexto diferente.

O exercício de abdução na presente tese consiste em redescrever o fenômeno da participação política dentro do novo contexto de uma interação Parlamento-sociedade mediada pelas TICs. Realiza-se uma nova interpretação sobre a efetividade da participação sociodigital a partir do estudo de sua conexão com a categoria da responsividade política.

\section{Retroducão}

Retrodução pode ser descrito como um modo de inferência pelo qual tentamos chegar no que é basicamente constitutivo e característico das estruturas. Busca-se as características básicas das estruturas gerais (DANERMARK; EKSTRÖM; JAKOBSEN; KARLSSON, 2002).

A ontologia do realismo crítico enfatiza a diferença entre eventos observáveis e os domínios da estrutura e dos mecanismos. A realidade social é composta de estruturas e objetos internamente relacionados contendo propriedades causalmente operacionais. $\mathrm{O}$ conhecimento desta realidade social só pode ser alcançado se formos além do que é empiricamente observável, fazendo perguntas sobre a realidade social e desenvolvendo conceitos sobre condições mais fundamentais e transfactuais para os eventos e fenômenos em estudo. A retrodução tem a ver com avançar, da observação empírica de eventos até uma conceituação das condições transfactuais.

O núcleo da retrodução é a argumentação transcendental, como é designada na filosofia. Por meio dessa argumentação, procura-se identificar e tornar claro os prérequisitos ou condições básicas para as relações sociais, as ações das pessoas e o conhecimento. O termo "condições" aqui significa as circunstâncias, sem as quais algo não pode existir. Tenta-se, ao mesmo tempo, separar as condições necessárias das circunstâncias contingentes. 
A presente pesquisa realiza um exercício de retrodução para se chegar às condições fundamentais que expliquem a reduzida efetividade da participação sociodigital, observada por meio das entrevistas e respostas ao questionário.

\subsection{Método explanatório}

A presente pesquisa faz uma apropriação do método explanatório proposto por Danermark, Ekström, Jakobsen e Karlsson (2002) e fundamentado na perspectiva ontológica do realismo crítico de Roy Bhaskar. O método procura auxiliar o pesquisador na tentativa de obter conhecimento sobre as qualidades constitutivas e os mecanismos causais que podem estar gerando os eventos, mas também no conhecimento de como diferentes mecanismos cooperam e, sob determinadas circunstâncias, contribuem para a produção de eventos e processos concretos. Nesta abordagem, no lugar da indução e da dedução, é a abdução e a retrodução que desempenham papéis centrais.

A abordagem baseia-se no pressuposto de que as estruturas fundamentais da explanação das ciências sociais podem ser descritas como um movimento do concreto para o abstrato, e de volta para o concreto. O modelo explicativo baseado no realismo crítico fornece orientações de como relacionar, na prática de pesquisa, o concreto ao abstrato e o abstrato ao concreto.

O modelo descreve o processo de investigação como um percurso do concreto (estágio 1) para o abstrato (estágios 2 a 5), e depois de volta para o concreto (estágio 6). Cada estágio, exceto o primeiro, envolve em si mesmo esse vai-e-vem entre os diferentes níveis de abstração (DANERMARK; EKSTRÖM; JAKOBSEN; KARLSSON, 2002, p. 109-110).

\section{Estágio 1: descricão}

Uma análise explicativa em ciências sociais geralmente começa no nível do concreto. Descrevemos a situação ou o evento, muitas vezes complexo e composto, que pretendemos estudar, fazendo uso de conceitos do dia-a-dia. Uma parte importante desta 
descrição são as interpretações das pessoas envolvidas e a forma como descrevem a situação atual. A maioria dos eventos deve ser descrita por métodos qualitativos e quantitativos.

A presente pesquisa procura descrever seu objeto - a participação sociodigital na Câmara dos Deputados e sua relação com o desenvolvimento humano - qualitativamente por meio de entrevistas e questionário semiestruturado e quantitativamente através de análise estatística (estatística descritiva e regressões Logística e de Poisson) da relação entre financiamento empresaria de campanhas e comportamento parlamentar.

\section{Estágio 2: resolucão analítica}

Nesta fase, separamos ou dissolvemos o composto e complexo, distinguindo os vários componentes, aspectos ou dimensões. O conceito de análise científica geralmente alude a apenas isso (análise = um exame para separar ou dissolver). Não é possível estudar algo em todos os seus diferentes componentes. Portanto, devemos nos limitar, na prática, ao estudo de certos componentes, e não de outros.

Para este estágio do método explanatório, a presente pesquisa realiza um recorte do tema mais abrangente da participação política, ao optar por investigar apenas a participação social que ocorre por meio da mediação das TICs, a participação sociodigital. Dentre as diversas relações que o sistema político localizado na Câmara dos Deputados mantém com os mais variados atores sociais, optou-se por estudar sua relação com o poder econômico representado por empresas privadas, com ênfase no setor industrial. A análise quantitativa do comportamento dos deputados analisou os votos nominais dos parlamentares durante votações ocorridas no período da $55^{\mathrm{a}}$ legislatura.

\section{Estágio 3: abducão/redescricãão teórica}

Aqui, interpretamos e redescrevemos os diferentes componentes/aspectos a partir de marcos conceituais hipotéticos e teorias sobre estruturas e relações. Esta fase corresponde, assim, ao que foi descrito anteriormente como abdução e redescrição. As ideias originais acerca dos objetos de estudo são desenvolvidas quando as colocamos em 
novos contextos de ideias. Neste momento, várias interpretações e explicações teóricas distintas podem e devem ser apresentadas, comparadas e, possivelmente, integradas umas às outras.

Neste sentido, a pesquisa analisa a participação sociodigital a partir das teorias da efetividade da participação política e do desenvolvimento humano, particularmente da Abordagem das Capacidades proposta por Amartya Sen e Martha Nussbaum, e da categoria teórica da responsividade política.

\section{Estágio 4: retroducão}

Neste estágio, são empregadas as diferentes estratégias metodológicas descritas anteriormente. O objetivo é que, para cada um dos diferentes componentes/aspectos que decidimos focar, possamos encontrar respostas a perguntas do tipo: $O$ que é fundamentalmente constitutivo para as estruturas e as relações $(\mathrm{X})$ destacadas no estágio 3 ? Como é possível X? Que propriedades devem existir para que X seja o que é? Que mecanismos causais estão relacionados a $\mathrm{X}$ ? Em processos concretos de pesquisa, tem-se que, em muitos casos, o acesso aos conceitos já estabelecidos fornece respostas satisfatórias a perguntas deste tipo. Na prática de pesquisa, os estágios 3 e 4 estão intimamente relacionados.

\section{Estágio 5: comparacão entre diferentes teorias e abstracõos}

Neste estágio, elabora-se e estima-se o poder explicativo relativo dos mecanismos e estruturas que foram descritos por meio de abdução e retrodução nos estágios 3 e 4. (Este estágio também pode ser descrito como parte do estágio 4.) Em alguns casos, pode-se concluir que uma teoria - ao contrário de outras teorias concorrentes - descreve as condições necessárias para o que deve ser explicado e, portanto, tem maior poder explicativo. Em outros casos, as teorias são complementares, concentrando-se parcialmente em condições necessárias, embora distintas.

\section{Estágio 6: concretizaç̃ão e contextualizaç̃ão}

A concretização envolve o exame de como as diferentes estruturas e os distintos mecanismos se manifestam em situações concretas. Aqui, destaca-se a importância em 
estudar a maneira pela qual mecanismos interagem com outros mecanismos em diferentes níveis, em condições específicas. O objetivo desses estudos é duplo: em primeiro lugar, interpretar os significados desses mecanismos quando entram no campo de visão em um determinado contexto; em segundo lugar, contribuir para explicações de eventos e processos concretos. É essencial que nestas explicações se possa distinguir entre as condições mais estruturais e as circunstâncias acidentais.

A figura a seguir resume o método explanatório adotado durante a pesquisa.

Figura 13 - Método explanatório para o objeto de pesquisa



Fonte: elaboração própria. 


\section{PARTE III - ESTUDO DE CASO}

O objetivo de um processo de abstração é chegar às "leis" gerais que regem um fenômeno social, assim como localizar suas especificidades e articulações concretas. Para tanto, é necessário situar essas "leis" gerais objetivamente, a partir dos elementos das particularidades.

Ao estudar uma realidade social, o fundamental é situá-la no âmbito da relação universal-particular. São as particularidades que dão os nexos à universalidade, que, por sua vez, concede o próprio sentido real à singularidade. Assim, a presente pesquisa pode ser interpretada como um esforço de compreensão das relações gerais entre a participação sociodigital e o tema do desenvolvimento, a partir da particularidade do sistema político existente na Câmara dos Deputados.

Considerando a realidade social complexa e multifacetada da participação sociodigital em suas relações com o tema do desenvolvimento, a pesquisa recorre a uma abordagem multimétodo com a combinação de um estudo extensivo de natureza quantitativa e uma pesquisa intensiva com uma abordagem qualitativa.

\section{Estruturação do estudo de caso}

A análise da efetividade da participação popular na Câmara dos Deputados será conduzida com base nas seguintes dimensões:

- Influência e responsividade:

- Influência dos cidadãos sobre as decisões políticas e responsividade dos deputados.

- Efeitos de socialização e psicológicos:

- Autopercepção do cidadão sobre sua capacidade de agir (senso de eficácia da participação); 
○ Percepção do cidadão em relação à responsividade dos parlamentares às suas manifestações no portal e-Democracia.

- Inclusão:

- Avaliação do perfil sociodemográfico dos participantes do portal eDemocracia.

A análise da influência e da responsividade segue o seguinte procedimento:

1. Para o período de 2014-2015, e com base nos relatórios de participação popular, publicados mensalmente pela Coordenação de Participação Popular (CPP) da Secretaria de Comunicação Social (SECOM) da Câmara dos Deputados e em dados consolidados sobre a participação popular pelo serviço Disque-Câmara, foram selecionadas seis proposições legislativas, correspondendo a sete matérias. A existência de manifestação de posição da Confederação Nacional da Indústria (CNI), em sua Agenda Legislativa para os anos de 2014 e 2015, foi outro critério para a seleção das matérias. Para a PEC da Reforma Política, PEC 182/2007 (PEC 352/2013 na CNI), a Agenda Legislativa da CNI para 2015 deixa claro a posição da Indústria apenas para os tópicos de "fím da reeleição" e da “coincidência de mandatos", razão pela qual foram os únicos tópicos da PEC 182/2007 a serem incluídos na lista de matérias a serem analisadas.

2. Para cada matéria selecionada no passo 1 , foram identificadas as posições (preferências) dos cidadãos e da CNI. Como premissa, considera-se que as posições da CNI, manifestas em suas Agendas Legislativas para 2014 e 2015, expressa os interesses dos doadores empresariais das campanhas eleitorais de 2010 e 2014 ligados ao setor industrial. Os interesses dos cidadãos são identificados a partir dos registros das manifestações populares recebidas através dos serviços Disque-Câmara e Fale Conosco para as matérias selecionadas.

3. O próximo passo consiste em identificar o comportamento parlamentar, em termos do voto nominal sobre cada matéria selecionada. O voto nominal expressa a decisão política sobre a matéria em questão.

4. Compara-se o grau de influência (participação) dos cidadãos sobre a decisão final expressa pelo voto nominal do deputado com a influência exercida 
pelos doadores de campanha. A responsividade dos parlamentares é interpretada como uma resposta à influência exercida previamente sobre o corpo político. Por exemplo, se o voto de um deputado sobre uma matéria coincide com a posição (voto) da Indústria, diz-se que o deputado "cooperou" com a Indústria, isto é, ele foi responsivo para com a Indústria, e pode-se afirmar que, para a matéria sob análise, a influência dos atores do setor industrial foi significativa. Nas matérias em que as posições da Indústria e dos Cidadãos são divergentes, a responsividade do deputado pode ser interpretada como sendo uma resposta à influência que foi preponderante para a decisão política sobre as demais, exercidas pelos demais atores que disputam o poder político.

A Agenda Legislativa da Confederação Nacional da Indústria (CNI), criada em 1996, "apresenta ao Parlamento e à sociedade em geral as principais proposições que geram impactos positivos ou negativos para o segmento industrial” (CNI, 2015, p. 11). A CNI coordena o trabalho anual de consolidação do posicionamento do setor sobre os temas analisados pelo Poder Legislativo, sendo, portanto, utilizada na presente pesquisa como expressão das preferências e interesses do setor industrial brasileiro em relação às matérias legislativas analisadas.

As informações de doações de campanhas eleitorais foram obtidas a partir dos registros das doações disponibilizados pelo Tribunal Superior Eleitoral (TSE).

A figura a seguir ilustra o procedimento de análise da efetividade da participação (influência).

Figura 14 - Procedimento de análise da influência

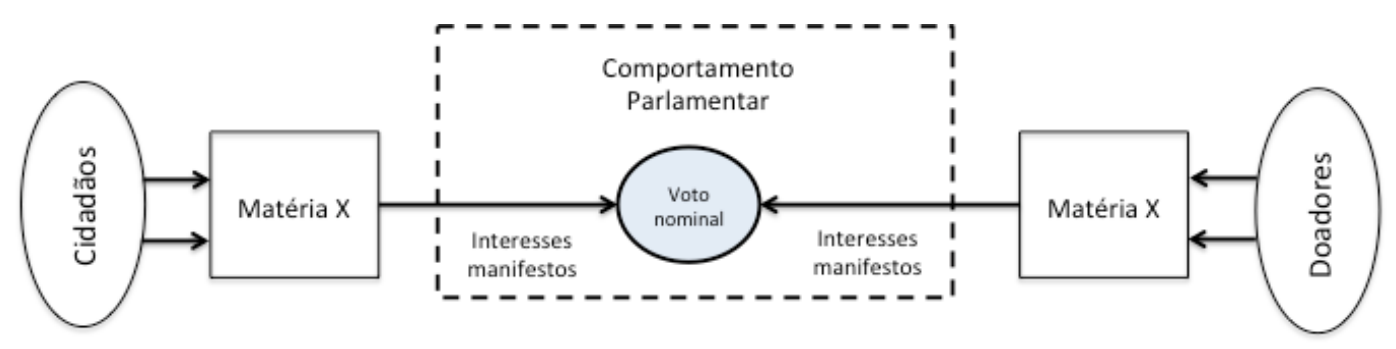

Fonte: elaboração própria. 
Os efeitos de socialização e psicológicos sobre os participantes - (1) autopercepção do cidadão sobre sua capacidade de agir (senso de eficácia da participação); e (2) percepção do cidadão em relação à responsividade dos parlamentares às suas manifestações no portal e-Democracia - foram mensurados por meio da aplicação de questionário online elaborado pelo autor da pesquisa para este fim (Apêndice III). O link para o questionário online foi enviado por correio eletrônico a 380 cidadãos cadastrados no portal e-Democracia da Câmara dos Deputados, obtendo-se 43 respostas. O questionário foi elaborado com a ferramenta Google Forms para construção e aplicação de questionários online.

A dimensão da inclusão foi realizada a partir de análise da diversidade e representatividade de uma amostra de cidadãos que utilizaram o portal e-Democracia para interagir com a Câmara dos Deputados, em relação a variáveis sociodemográficas como idade, sexo, UF e escolaridade. Para os 43 participantes do portal e-Democracia, os dados sociodemográficos foram levantados durante a aplicação do questionário online.

A partir das entrevistas foi possível conhecer a percepção dos gestores sobre a participação popular na Câmara dos Deputados, em geral, e sobre as principais dificuldades encontradas e desafios a serem superados para uma efetiva participação, além da percepção dos gestores sobre o comportamento dos parlamentares, em termos de responsividade às demandas dos cidadãos.

As dimensões para a avaliação da efetividade da participação e os respectivos instrumentos utilizados são resumidos na Tabela 4.

Tabela 4 - Dimensões e métodos para avaliação da participação

\begin{tabular}{|c|c|c|c|}
\hline Categoria & Critério & Método & Cidadãos no \\
\hline \multirow[t]{2}{*}{ Efeitos de socialização e psicológicos } & $\begin{array}{l}\text { Autopercepção da capacidade de agir dos } \\
\text { cidadãos (eficácia da participação). }\end{array}$ & Questionário. & \multirow[t]{3}{*}{ e-Democracia } \\
\hline & $\begin{array}{l}\text { percepção do cidadão em relação à } \\
\text { responsividade dos parlamentares às } \\
\text { suas manifestações no portal e- } \\
\text { Democracia. }\end{array}$ & Questionário. & \\
\hline Inclusão & $\begin{array}{l}\text { Representatividade da amostra de } \\
\text { participantes do portal e-Democracia. }\end{array}$ & $\begin{array}{l}\text { Análise de dados sociodemográficos } \\
\text { - Questionário. }\end{array}$ & \\
\hline Influência e responsividade & $\begin{array}{l}\text { Influência sobre as decisões políticas e } \\
\text { responsividade dos deputados. }\end{array}$ & $\begin{array}{l}\text { Análise dos votos nominais dos } \\
\text { deputados para cada matéria } \\
\text { legislativa, questionário e } \\
\text { entrevistas. }\end{array}$ & $\begin{array}{l}\text { e-Democracia e } \\
\text { Disque-Câmara }\end{array}$ \\
\hline
\end{tabular}


Fonte: elaboração própria.

Foram realizadas três entrevistas com os gestores das seguintes instituições participativas: (1) portal e-Democracia, (2) serviços Disque-Câmara e Fale Conosco e (3) Comissão de Legislação Participativa (CLP). As entrevistas foram do tipo interativa e estruturadas em três blocos:

- $\quad$ Histórico da Instituição Participativa (IP);

- $\quad$ Descrição do funcionamento da IP;

- Dificuldades, problemas e desafios.

\section{Responsividade dos deputados - Modelagem quantitativa}

A modelagem quantitativa da presente pesquisa segue construção similar à adotada no trabalho realizado por um grupo de pesquisadores da Universidade Federal de Minas Gerais (UFMG) e da Universidade Federal de Pernambuco (UFPE) sobre financiamento de campanha e apoio parlamentar à Agenda Legislativa da Indústria na Câmara dos

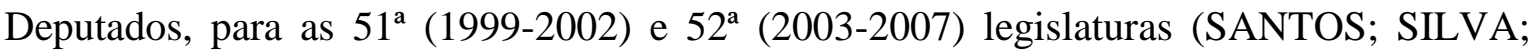
FILHO; ROCHA, 2015).

Para se verificar a influência do financiamento de campanha sobre o comportamento parlamentar, a pesquisa inicialmente tinha o objetivo de analisar os

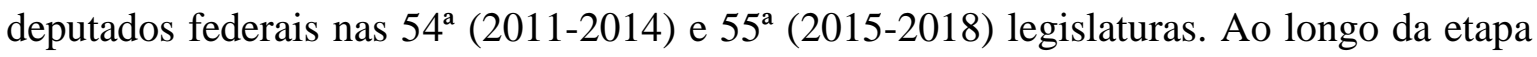
de coleta de dados sobre as manifestações dos cidadãos, da Indústria e dos votos dos deputados, verificou-se a necessidade de exclusão de algumas matérias legislativas, dentre as quais as duas matérias da $54^{\mathrm{a}}$ legislatura. Assim, a análise ficou restrita ao período da atual 55 ${ }^{\mathrm{a}}$ legislatura (2015-2018).

A cooperação com a indústria é observada pela votação do parlamentar de acordo com a posição da CNI, expressa na Agenda Legislativa da entidade. Como no processo legislativo brasileiro nem todas as matérias são votadas nominalmente, as proposições 
selecionadas correspondem a dois critérios: 1) às matérias identificadas nas Agendas Legislativas da Indústria, a partir das quais se verifica se ela é de interesse do setor e qual seu posicionamento sobre ela; e 2) às matérias que foram objeto de votação nominal no Plenário da Câmara dos Deputados.

Em geral, o parlamentar vota a matéria, mas, sob certas circunstâncias, as votações nominais acontecem para requerimentos procedimentais e determinados artigos ou mesmo termos específicos via "destaque para votação em separado". Como não é possível identificar a posição da CNI nessas situações, optou-se por considerar apenas as votações mais relevantes e substantivas sobre o conteúdo da matéria. A análise focou inicialmente em 7 matérias que obedecem a tais critérios nas duas legislaturas em questão, sendo 5 matérias votadas na $55^{\mathrm{a}}$ legislatura e 2 matérias com votação durante a $54^{\mathrm{a}}$ legislatura. Das sete matérias selecionadas, duas são de um mesmo Projeto de Emenda Constitucional (PEC), três são Projetos de Lei (PL) e duas são Medidas Provisórias (MPV). As matérias com descrição dos assuntos tratados e as legislaturas em que foram votadas estão indicadas na Tabela 5 .

Tabela 5 - Matérias legislativas selecionadas

\begin{tabular}{|c|c|c|c|c|c|c|c|}
\hline Proposição & Descrição Proposição & Matéria & Código Matéria & \multicolumn{2}{|c|}{ Votação substantiva } & \multicolumn{2}{|c|}{\begin{tabular}{|c|}
$\begin{array}{c}\text { Legislatura votação na } \\
\text { Câmara }\end{array}$ \\
\end{tabular}} \\
\hline \multirow[t]{2}{*}{$\begin{array}{l}\text { PEC 182/2007 (PEC } \\
352 / 2013 \text { NA CNI) }\end{array}$} & $\begin{array}{c}\text { Altera os arts. } 17,46 \text { e } 55 \text { da } \\
\text { Constituição Federal, para assegurar aos } \\
\text { partidos pol'ticos a titularidade dos }\end{array}$ & FIM DA REELEIÇÃO & M1 & $\begin{array}{l}\text { Art } 3 \text { do substitutivo pelo } \\
\text { relator da comissão especial }\end{array}$ & $27 / 05 / 2015$ & & $\mathrm{x}$ \\
\hline & $\begin{array}{c}\text { mandatos parlamentares e estabelecer a } \\
\text { perda dos mandatos dos membros do } \\
\text { Poder Legislativo e do Poder Executivo } \\
\text { que se desfiliarem dos partidos pelos } \\
\text { quais forem eleitos. }\end{array}$ & $\begin{array}{c}\text { COINCIDÊNCIA DE } \\
\text { MANDATOS }\end{array}$ & M2 & $\begin{array}{c}\text { Emenda aglutinativa n. } 48 \\
\text { (Tempo de mandato e } \\
\text { coincidência escalonada das } \\
\text { eleições) }\end{array}$ & 10/06/2015 & & $\mathrm{x}$ \\
\hline PL 4330/2004 & $\begin{array}{l}\text { Dispõe sobre os contratos de } \\
\text { terceirização e as relações de trabalho } \\
\text { deles decorrentes. }\end{array}$ & PL 4330/2004 & M3 & $\begin{array}{l}\text { Subemenda substitutiva } \\
\text { global }\end{array}$ & 08/04/2015 & & $\mathrm{x}$ \\
\hline MPV 664/2014 & $\begin{array}{l}\text { Estabelece novas regras para concessão } \\
\text { do auxílio doeença e pensão por morte. }\end{array}$ & MPV 664/2014 & M4 & $\begin{array}{c}\text { Projeto de Lei de Conversão } \\
\text { n. } 4 \text { de } 2015 \\
\end{array}$ & $13 / 04 / 2015$ & & $x$ \\
\hline PL 8035/2010 & $\begin{array}{c}\text { Aprova o Plano Nacional de Educação } \\
\text { para o decênio 2011-2020 e dá outras } \\
\text { providências. }\end{array}$ & PL 8035/2010 & M6 & $\begin{array}{l}\text { Votação redação final } \\
\text { Substitutivo Senado }\end{array}$ & 03/06/2014 & $\mathrm{x}$ & \\
\hline PL 2126/2011 & $\begin{array}{c}\text { Estabelece princípios, garantias, direitos } \\
\text { e deveres para o uso da Internet no } \\
\text { Brasil. }\end{array}$ & PL 2126/2011 & M7 & Votação redação final & $25 / 03 / 2014$ & $\mathrm{x}$ & \\
\hline
\end{tabular}

Fonte: elaboração própria. 
A posição da indústria quanto à matéria é classificada na Agenda Legislativa da CNI como "convergente", "convergente com ressalvas", "divergente com ressalvas" e "divergente". Contudo, para fins de modelagem estatística agrupou-se as posições em apenas convergente ou divergente. A cooperação com os interesses da indústria é identificada quando o deputado vota de acordo com a posição da CNI, ou seja, vota a favor quando a posição da indústria é "convergente" e vota contra quando a posição da indústria é "divergente". A cooperação com os interesses dos cidadãos é identificada quando o deputado vota de acordo com a posição majoritária dos cidadãos para a matéria, ou seja, vota favoravelmente quando a posição majoritária dos cidadãos é a favor e vota contra quando a posição majoritária dos cidadãos é contra.

A posição majoritária dos cidadãos foi derivada do computo dos votos a favor e contrários para cada matéria, registrados no banco de dados do serviço Disque-Câmara da Câmara dos Deputados. Utilizou-se o mesmo critério de aprovação adotado nas deliberações da Câmara dos Deputados para projetos de leis ordinárias, decretos legislativos e resoluções (artigo 183 do Regimento Interno da Câmara), isto é, a maioria simples de votos. A maioria simples é o primeiro número inteiro após a metade dos "presentes". A título de exemplo, para uma matéria com 12 manifestações favoráveis por parte dos cidadãos e 15 manifestações contrárias, a maioria simples seria o inteiro 14 (primeiro inteiro após 13,7= metade de 27). Neste caso, como o total de votos contrários satisfez ao critério da maioria simples (15 >=14), a posição majoritária (vencedora) e que representará a preferência dos cidadãos para a matéria será "contrária" ao conteúdo da matéria legislativa e, portanto, pela sua rejeição.

A análise de responsividade dos parlamentares é realizada em duas etapas. Primeiramente, compara-se, para cada matéria, o voto nominal de cada deputado com a posição da indústria (CNI). Em seguida, compara-se, para cada matéria, o voto nominal de cada deputado com a posição majoritária dos cidadãos.

Para a análise quantitativa, foram combinadas diferentes técnicas estatísticas: estatística descritiva, regressão logística e regressão de Poisson. Visando captar diferentes níveis de análise, optou-se pela utilização de quatro especificações diferentes para a variável dependente. Nas duas primeiras, a matéria é a unidade de análise, e é observado se o deputado coopera (é responsivo) ou não coopera com os interesses da indústria e dos 
cidadãos. Nesse caso, trata-se de uma variável qualitativa binária que assume valor 1 quando o parlamentar vota favoravelmente aos interesses da indústria ou dos cidadãos, e 0 quando vota de forma contrária aos interesses da indústria ou dos cidadãos. As variáveis dependentes são RI e RC, Responsividade à Indústria e Responsividade aos Cidadãos, respectivamente.

Para a terceira e quarta especificações, utiliza-se o grau de responsividade (GR), ou seja, o número absoluto de vezes que o deputado votou a favor dos interesses da indústria ou dos cidadãos. São duas variáveis de contagem com valores inteiros e positivos. O uso de quatro especificações da variável dependente tem por objetivo explicar a cooperação (responsividade) ou não cooperação do parlamentar com a indústria, por um lado, e com os cidadãos, por outro, controlando por características tanto da matéria quanto do parlamentar. Usando a analogia de vetores, a variável responsividade representa a direção e o sentido do vetor $\mathrm{R}$ (vetor Resposta do deputado), enquanto o grau de responsividade corresponde ao valor do módulo (intensidade) do vetor R. A figura a seguir ilustra a analogia com vetores. As duas variáveis dependentes são GRI e GRC, Grau de Responsividade à Indústria e Grau de Responsividade aos Cidadãos, respectivamente.

Figura 15 - Responsividade e grau de responsividade.

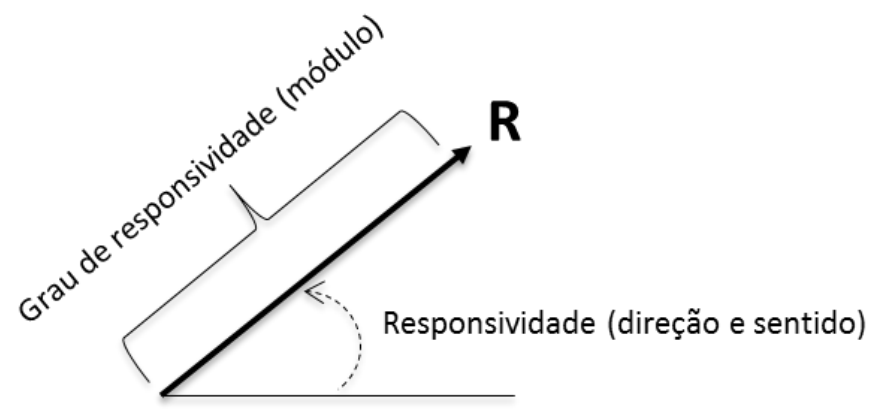

Fonte: elaboração própria.

Para as duas primeiras variáveis dependentes (RI e RC), o modelo de regressão logística é adequado para estimar a probabilidade do deputado em cooperar com a indústria ou com os cidadãos. Já as duas últimas especificações da variável dependente, GRI e GRC, constituem-se no número de vezes que o deputado votou com a indústria ou com os 
cidadãos. Como essas variáveis apresentam somente valores inteiros e positivos, o modelo de regressão linear de mínimos quadrados ordinários não se mostra adequado, sendo o modelo de regressão de Poisson mais apropriado (LONG; FREESE, 2001).

Três especificações foram utilizadas para operacionalizar a principal variável independente, o financiamento de campanha. A primeira especificação é a proporção das doações de campanha do deputado $i$ na legislatura $j$ oriunda da indústria. No modelo, essa variável denomina-se proporção da indústria (PI). Para identificar se uma empresa doadora pertence ao setor industrial, utilizou-se a Classificação Nacional de Atividades Econômicas (CNAE) do Instituto Brasileiro de Geografia e Estatística (IBGE). Na CNAE, o setor industrial corresponde às seções B e C - Indústrias extrativas e Indústrias de transformação, respectivamente.

A segunda especificação é a proporção das doações de campanha do deputado $i$ na legislatura $j$ oriunda de pessoas jurídicas em geral, denominada de proporção de pessoas jurídicas (PJ). A terceira especificação é a proporção das doações de campanha do deputado $i$ na legislatura $j$ em relação ao valor total das doações recebidas por todos os deputados eleitos. Esta variável é denominada de proporção das doações (PD), sendo uma medida de quão cara foi a campanha eleitoral de um deputado em particular, relativa às campanhas dos demais deputados. As três especificações ajudam a explorar mais amplamente o fenômeno do financiamento de campanhas eleitorais.

A análise da responsividade buscou verificar as relações das três variáveis independentes (PI, PJ e PD) com a probabilidade de cooperação dos deputados com a indústria e com os cidadãos, e o grau dessa responsividade.

A figura a seguir ilustra a estrutura analítica utilizada: 
Figura 16 - Estrutura analítica

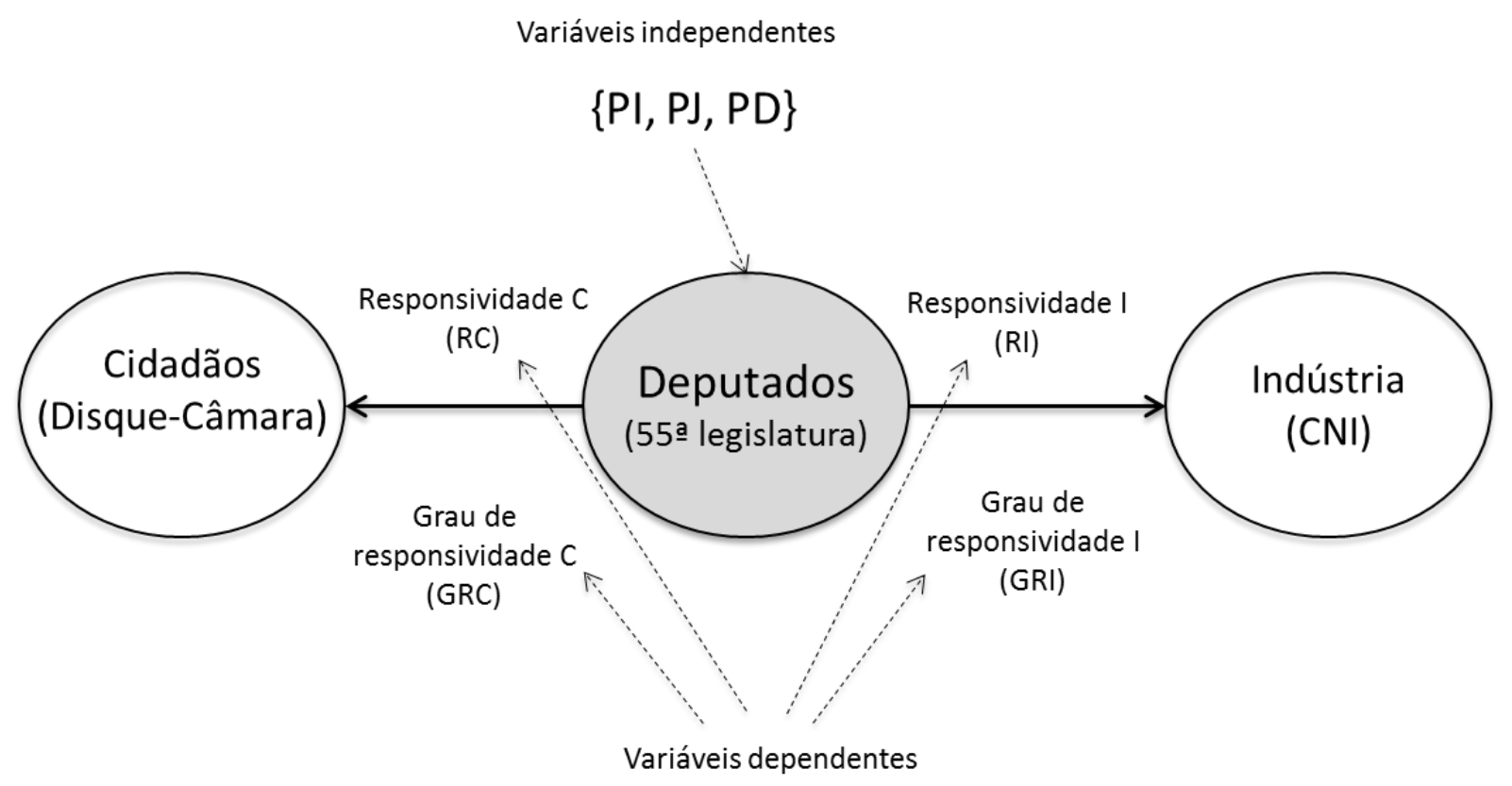

Fonte: elaboração própria.

A Tabela 6 sumariza as principais características da modelagem quantitativa para a análise da responsividade dos deputados: 
Tabela 6 - Modelagem da análise de responsividade

\begin{tabular}{|c|c|c|}
\hline População & \multicolumn{2}{|c|}{$\begin{array}{l}\text { Deputados federais das 55a }(2015-2018) \text { legislatura, num total } 513 \text { parlamentares, sendo } \\
\mathbf{4 6 0} \text { deputados votantes, totalizando } \mathbf{1 2 6 5} \text { votos em plenário. }\end{array}$} \\
\hline \multirow{7}{*}{ Variáveis } & \multirow{4}{*}{ Dependentes } & $\begin{array}{l}\text { Responsividade I (RI): assume valor } 1 \text { quando o deputado vota a favor do } \\
\text { interesse da indústria e } 0 \text { quando vota contra. Unidade de análise: } \\
\text { deputado i na matéria j. }\end{array}$ \\
\hline & & $\begin{array}{l}\text { Responsividade C (RC): assume valor } 1 \text { quando o deputado vota a favor do } \\
\text { interesse dos cidadãos e } 0 \text { quando vota contra. Unidade de análise: } \\
\text { deputado i na matéria j. }\end{array}$ \\
\hline & & $\begin{array}{l}\text { Grau de responsividade I (GRI): número de vezes que o deputado i votou a } \\
\text { favor dos interesses da indústria na legislatura j. }\end{array}$ \\
\hline & & $\begin{array}{l}\text { Grau de responsividade C (GRC): número de vezes que o deputado i votou } \\
\text { a favor dos interesses dos cidadãos na legislatura j. }\end{array}$ \\
\hline & \multirow{3}{*}{ Independentes } & $\begin{array}{l}\text { Proporção da indústria (PI): proporção do financiamento de campanha do } \\
\text { deputado i na legislatura j oriundo da indústria. }\end{array}$ \\
\hline & & $\begin{array}{l}\text { Proporção de pessoa jurídica (PJ): proporção do financiamento de } \\
\text { campanha do deputado i na legislatura j oriundo de empresas em geral. }\end{array}$ \\
\hline & & $\begin{array}{l}\text { Proporção das doações (PD): proporção do financiamento de campanha do } \\
\text { deputado i na legislatura j em relação ao valor total recebido por todos os } \\
\text { deputados eleitos. }\end{array}$ \\
\hline
\end{tabular}

Fonte: elaboração própria. 


\section{PARTE IV - RESULTADOS}

\section{Responsividade - Pesquisa extensiva}

\subsection{Posições dos cidadãos}

O primeiro passo para investigar a influência dos cidadãos nas decisões políticas dos deputados é conhecer as posições ou preferências dos cidadãos para cada matéria legislativa selecionada. As posições dos cidadãos foram obtidas a partir dos registros das manifestações populares para as matérias selecionadas, através de chamadas telefônicas realizadas para a central de relacionamento vinculada ao serviço Disque-Câmara. Os dados obtidos estão resumidos na tabela a seguir.

Tabela 7 - Manifestações dos cidadãos para as matérias legislativas

\begin{tabular}{|c|c|c|c|c|c|c|}
\hline \multicolumn{5}{|c|}{$\begin{array}{l}\text { QUANTITATIVO DE MANIFESTAÇÕES SOBRE PROPOSIÇÕES NO ANO DE } \\
\qquad 2015\end{array}$} & \multirow{2}{*}{ VOTO CIDADÃOS } & \multirow{2}{*}{$\begin{array}{c}\text { Margem } \\
\text { posição } \\
\text { vencedora } \\
\text { (\%) }\end{array}$} \\
\hline PROPOSIÇÃO & Matéria & CONTRÁRIA & FAVORÁVEL & GERAL & & \\
\hline $\begin{array}{l}\text { PEC 182/2007 - FIM } \\
\text { DA REELEICAAO }\end{array}$ & M1 & 11 & 73 & 84 & SIM & 86,90 \\
\hline $\begin{array}{l}\text { PEC } 182 / 2007- \\
\text { COINCIDÊNCIA DE } \\
\text { MANDATOS }\end{array}$ & M2 & 6 & 14 & 20 & SIM & 70,00 \\
\hline PL 4330/2004 & M3 & 1.530 & 97 & 1.627 & NÃO & 94,04 \\
\hline MPV 664/2014 & M4 & 359 & 113 & 472 & NÃO & 76,06 \\
\hline MPV 665/2014 & M5 & 131 & 18 & 149 & NÃO & 87,92 \\
\hline \multicolumn{5}{|c|}{$\begin{array}{l}\text { QUANTITATIVO DE MANIFESTAÇÕES SOBRE PROPOSIÇÕES NO ANO DE } \\
2014\end{array}$} & \multirow{2}{*}{ VOTO CIDADÃOS } & \multirow{2}{*}{$\begin{array}{c}\text { Margem } \\
\text { posição } \\
\text { vencedora } \\
\text { (\%) }\end{array}$} \\
\hline PROPOSIÇÃO & Matéria & CONTRÁRIA & FAVORÁVEL & GERAL & & \\
\hline PL 8035/2010 & M6 & 3.116 & 72 & 3.188 & NÃO & 97,74 \\
\hline PL 2126/2011 & M7 & 1.394 & 30 & 1.424 & NÃO & 97,89 \\
\hline
\end{tabular}

Fonte: elaboração própria, a partir de dados fornecidos pela Câmara dos Deputados.

A tabela exibe os quantitativos de manifestações contrárias, favoráveis e o total de manifestações para cada matéria. A posição que obteve maioria simples é considerada a 
posição vencedora e representativa da preferência dos cidadãos sobre a matéria. As margens das posições vencedoras variam entre $70 \%$ e $97,89 \%$ em relação à quantidade total de manifestações para a matéria. Para as matérias M1 a M5, as manifestações populares ocorreram no ano de 2015. Para as matérias M6 e M7, em 2014.

Tudo se passa como se o canal disponibilizado pelo serviço Disque-Câmara funcionasse como uma espécie de Ágora ateniense para onde os cidadãos podem se dirigir e manifestar publicamente suas preferências (votos) sobre assuntos de seu interesse. A central de relacionamento, ao receber as manifestações espontâneas dos cidadãos, simula um espaço de democracia direta, onde as decisões políticas seriam tomadas com base na manifestação direta dos cidadãos sobre os assuntos de interesse de uma comunidade política. O serviço Disque-Câmara não constitui, entretanto, um espaço para discussão e deliberação, com vistas à formação de preferências. Pressupõe-se que a deliberação e a formação da opinião pública tenham ocorrido em momento anterior às manifestações, a partir dos processos de socialização no seio da sociedade.

Como o processo de manifestação dos cidadãos acontece por um processo aleatório e espontâneo, podemos afirmar que as amostras das manifestações são representativas, já que têm as mesmas características da população de eleitores.

\subsection{Posição da Indústria}

O segundo passo é identificar as posições da Indústria. Para tanto, recorreu-se às manifestações da Confederação Nacional da Indústria (CNI) sobre as matérias selecionadas para estudo, registradas em sua Agenda Legislativa para os anos de 2015 e 2014. A tabela a seguir resume as posições da CNI para as matérias de interesse. 
Tabela 8 - Manifestações da Indústria

\begin{tabular}{|l|c|c|}
\hline \multicolumn{1}{|c|}{ PROPOSIÇÃO } & Matéria & VOTO CNI \\
\hline PEC 182/2007 (FIM DA REELEIÇÃO) & M1 & SIM \\
\hline $\begin{array}{l}\text { PEC 182/2007 (COINCIDÊNCIA DE } \\
\text { MANDATOS) }\end{array}$ & M2 & SIM \\
\hline PL 4330/2004 & M3 & SIM \\
\hline MPV 664/2014 & M4 & SIM \\
\hline MPV 665/2014 & M5 & SIM \\
\hline PL 8035/2010 & M6 & SIM \\
\hline PL 2126/2011 & M7 & SIM \\
\hline
\end{tabular}

Fonte: elaboração própria.

A posição da CNI para todas as matérias é sempre "favorável”, o que equivale ao voto "SIM". Para o objetivo de conhecer se a responsividade dos deputados está orientada aos interesses dos cidadãos ou da Indústria, é interessante analisar somente os casos em que esses interesses divergem em relação à matéria de interesse. Portanto, descartam-se as matérias M1 e M2, dado que nestes dois casos as posições dos cidadãos e da Indústria são coincidentes.

A Tabela 9 resume, então, o quadro de matérias e os respectivos votos, após o descarte das matérias M1 e M2.

Tabela 9 - Quadro de matérias e votos, após exclusão de M1 e M2

\begin{tabular}{|l|c|c|c|}
\hline \multicolumn{1}{|c|}{ PROPOSIÇÃo } & Matéria & $\begin{array}{c}\text { VOTO } \\
\text { CIDADÃOS }\end{array}$ & VOTO CNI \\
\hline PL 4330/2004 & M3 & NÃO & SIM \\
\hline MPV 664/2014 & M4 & NÃO & SIM \\
\hline MPV 665/2014 & M5 & NÃO & SIM \\
\hline PL 8035/2010 & M6 & NÃO & SIM \\
\hline PL 2126/2011 & M7 & NÃO & SIM \\
\hline
\end{tabular}

Fonte: elaboração própria.

Destaca-se que para a PEC 182/2007, PEC da Reforma Política, não houve manifestação clara por parte da CNI sobre os pontos mais debatidos pela sociedade, como 
o fim do financiamento empresarial de campanhas e voto distrital. Sobre o modelo de financiamento de campanhas, a CNI manifestou-se apenas no sentido de que esse ponto deveria "ser melhor debatido com a sociedade" (CNI, 2015, p. 86).

\subsection{Posição dos deputados}

O próximo passo é conhecer as posições dos deputados federais sobre as matérias. As posições são manifestas pelos votos nominais de cada deputado em sessão plenária deliberativa sobre a matéria em questão. O voto nominal é a decisão política do parlamentar para o conteúdo da matéria. As tabelas com os votos nominais dos deputados são apresentadas no Apêndice I.

Para as matérias M6 (PL 8035/2010) e M7 (PL 2126/2011), quase a totalidade dos votos dos deputados foram favoráveis, resultado que diverge significativamente em relação às matérias M3 a M5. A tabela a seguir resume as quantidades de votos para as matérias.

Tabela 10 - Resumo votação para as matérias M3 a M7

\begin{tabular}{|c|c|c|c|c|c|c|}
\hline \multirow{2}{*}{ PROPOSIÇÃO } & \multirow{2}{*}{ Matéria } & \multicolumn{4}{|c|}{ Votos } & \multirow{2}{*}{$\begin{array}{c}\text { \% Votos } \\
\text { favoráveis }\end{array}$} \\
\hline & & SIM & NÃO & ABSTENÇÃO & TOTAL & \\
\hline PL 4330/2004 & M3 & 324 & 137 & 2 & 463 & 69,98 \\
\hline MPV 664/2014 & $\overline{M 4}$ & 277 & 178 & 1 & 456 & 60,75 \\
\hline MPV 665/2014 & M5 & 252 & 227 & 1 & 480 & 52,50 \\
\hline PL 8035/2010 & M6 & 381 & 2 & 1 & 384 & 99,22 \\
\hline PL 2126/2011 & M7 & 399 & 1 & 0 & 400 & 99,75 \\
\hline
\end{tabular}

Fonte: elaboração própria.

O percentual de votos favoráveis na votação da matéria M6 foi de 99,22\%, e para a matéria M7, de 99,75\%, ou seja, quase a unanimidade pela aprovação da matéria. Em geral, a unanimidade é algo muito raro em votações com cerca de 400 deputados presentes, principalmente se considerarmos que temos uma grande quantidade de partidos no sistema político brasileiro, com diferentes posições políticas. Existem 28 partidos representados na atual legislatura na Câmara dos Deputados. Mesmo se considerarmos uma polarização do 
tipo governistas versos oposicionistas, os resultados das votações deveriam refletir, em algum grau, esta polarização. Como os cidadãos manifestaram-se de forma contrária à aprovação das matérias M6 e M7, os resultados das votações na Câmara dos Deputados estaria indicando que quase a totalidade dos parlamentares presentes nas sessões deliberativas para votação das matérias M6 e M7 preferiram contrariar os interesses dos cidadãos, o que seria muito improvável de ocorrer.

Uma explicação para os resultados das votações para as matérias M6 e M7 seria que as versões finais dos textos das proposições sofreram grande alteração quando comparado com o texto original submetido à Câmara dos Deputados. Desta forma, as manifestações dos cidadãos estariam referindo-se à versão original da proposição, enquanto as manifestações (votos) dos deputados se referem à versão final do texto, significativamente modificada durante sua tramitação na Câmara dos Deputados. Isso é confirmado quando analisamos o grau de alterações nos textos das proposições durante sua tramitação (Tabela 11).

Tabela 11 - Grau de alterações nos textos das proposições

\begin{tabular}{|c|c|c|c|c|c|c|c|c|}
\hline \multirow[b]{2}{*}{ PROPOSIÇÃO } & \multirow[b]{2}{*}{ Matéria } & \multirow{2}{*}{$\begin{array}{c}\text { Data texto } \\
\text { original }\end{array}$} & \multirow{2}{*}{$\begin{array}{l}\text { Data votação } \\
\text { substantiva }\end{array}$} & \multicolumn{5}{|c|}{ Alterações em relação texto original } \\
\hline & & & & Inserções & Deleções & Movimentações & Total & Variação \% \\
\hline PL 4330/2004 & M3 & $26 / 10 / 04$ & $08 / 04 / 15$ & 110 & 106 & 44 & 260 & 42,86 \\
\hline MPV 664/2014 & M4 & $30 / 12 / 14$ & 13/04/15 & 129 & 104 & 17 & 250 & 37,36 \\
\hline MPV 665/2014 & M5 & $30 / 12 / 14$ & $06 / 05 / 15$ & 100 & 82 & 0 & 182 & - \\
\hline PL 8035/2010 & M6 & $20 / 12 / 10$ & $03 / 06 / 14$ & 1118 & 949 & 4 & 2071 & 1037,91 \\
\hline PL 2126/2011 & M7 & $24 / 08 / 11$ & $25 / 03 / 14$ & 388 & 354 & 14 & 756 & 315,38 \\
\hline
\end{tabular}

Fonte: elaboração própria.

É notório, pela Tabela 11, que as matérias M6 e M7 sofreram alterações significativamente maiores nos textos das proposições, se comparadas às mudanças ocorridas nos textos das matérias M3, M4 e M5. O texto original da matéria M6 sofreu 2.071 alterações durante sua tramitação, quando comparado à redação final aprovada em 03/06/2015. Para a matéria M7, foram 756 alterações no texto original. Comparando-se com a matéria que recebeu o menor número de alterações, M5 (MPV 665/2014), com 182 alterações ocorridas no texto original, o percentual total de alterações nos textos das matérias M6 e M7 foram 1.037,91\% e 315,38\% superiores, respectivamente. 
Em função desse resultado, foi necessário descartar as matérias M6 e M7 da análise de responsividade, posto que os cidadãos e os deputados manifestaram-se, muito provavelmente, em relação a versões muito díspares, em seu conteúdo, dos textos das proposições PL 8035/2010 e PL 2126/2011, respectivamente.

Desta forma, a análise de responsividade dos deputados em relação aos interesses da Indústria e dos cidadãos foi realizada para as matérias M3, M4 e M5. A Tabela 12 resume os votos dos cidadãos e da CNI para essas matérias.

Tabela 12 - Matérias para análise de responsividade

\begin{tabular}{|c|c|c|c|c|}
\hline PROPOSIÇÃO & Conteúdo & Matéria & VOTO CNI & VOTO CIDADÃOS \\
\hline PL 4330/2004 & $\begin{array}{c}\text { Contratos de } \\
\text { terceirização e as } \\
\text { relações de trabalho } \\
\text { deles decorrentes. }\end{array}$ & M3 & SIM & NÃO \\
\hline MPV 664/2014 & $\begin{array}{c}\text { Novas regras para } \\
\text { concessão do auxílio } \\
\text { doeença e pensão } \\
\text { por morte. }\end{array}$ & M4 & SIM & NÃO \\
\hline MPV 665/2014 & $\begin{array}{c}\text { Novas regras para } \\
\text { concessão do seguro } \\
\text { desemprego e do } \\
\text { abono salarial. }\end{array}$ & M5 & SIM & NÃO \\
\hline
\end{tabular}

Fonte: elaboração própria.

\subsection{Responsividade dos deputados}

A responsividade do corpo político da Câmara dos Deputados corresponde à cooperação dos deputados aos interesses manifestos dos doadores de campanha pertencentes ao setor industrial da economia ou aos interesses dos cidadãos. Para a responsividade à Indústria, foi especificada uma variável do tipo binária ou dicotômica, RI, que assume o valor "1" quando a posição do deputado coincide com a posição da Indústria, 
e "0" quando as posições divergem. O gráfico a seguir apresenta a distribuição (histograma) da variável RI para o conjunto das três matérias M3, M4 e M5.

No eixo y tem-se a quantidade de votos nominais para o conjunto das matérias e no eixo x os valores para a variável binária RI.

Figura 17 - Distribuição da Responsividade à Indústria (RI)

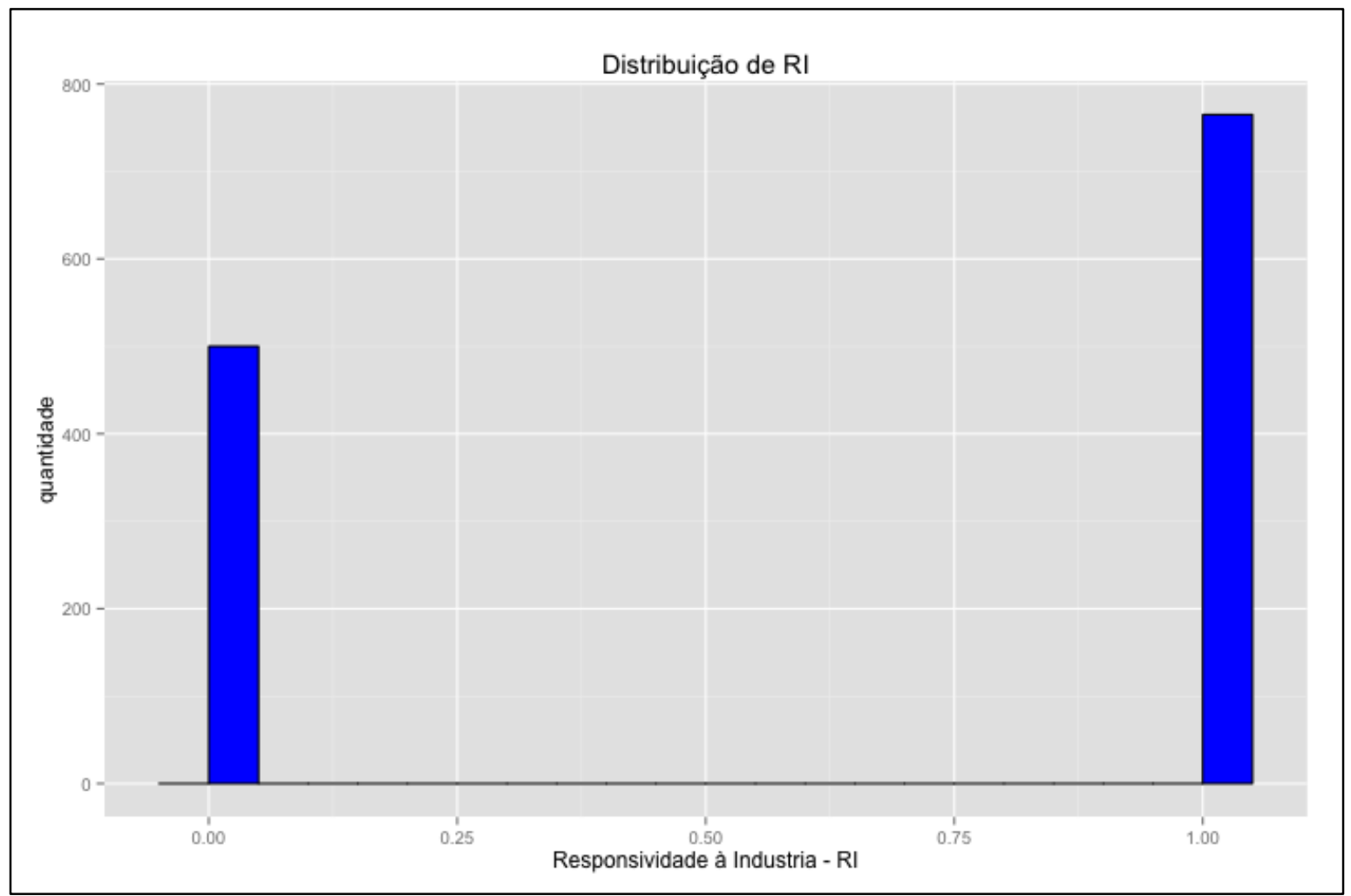

Fonte: elaboração própria.

Pelo gráfico, do total de 1265 votos nominais dos parlamentares para as três matérias analisadas, tem-se 765 votos que coincidem com a posição da Indústria e 500 votos contrários. Isso significa que em $60 \%$ dos casos, os deputados cooperaram com a Indústria (e não cooperaram com os cidadãos) e em $40 \%$ dos casos os deputados cooperaram com os cidadãos (e não cooperaram com a Indústria).

Como para todas as matérias as posições (votos) da Indústria e dos cidadãos são divergentes entre si, a cooperação de um deputado à Indústria significa automaticamente a não-cooperação com os interesses dos cidadãos, o que equivale afirmar que se o deputado 
é responsivo aos interesses da Indústria, ele não o é aos interesses dos cidadãos para a matéria ou conjunto de matérias em questão.

A segunda especificação da variável dependente é o grau de cooperação ou grau de responsividade, com base no número de vezes que o parlamentar votou com os interesses da indústria. O grau de responsividade do deputado à Indústria é representado pela variável dependente do tipo contagem, GRI, cuja distribuição é apresentada no gráfico a seguir.

Figura 18 - Distribuição do Grau de Responsividade à Indústria (GRI)

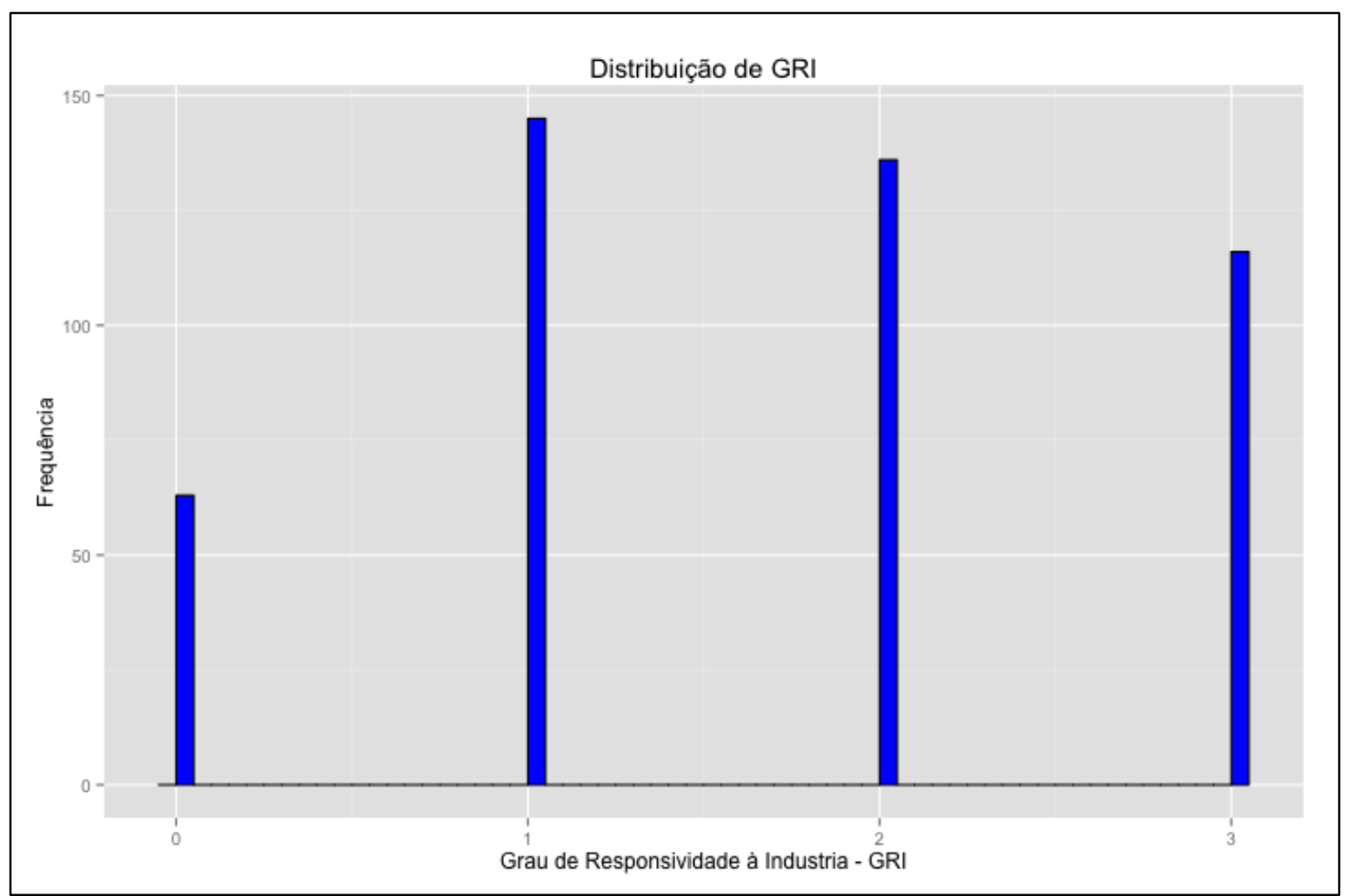

Fonte: elaboração própria.

O gráfico mostra a distribuição do número de votos a favor dos interesses da indústria. Os valores possíveis são $0,1,2$ ou 3 votos. A distribuição percentual para os valores de GRI são: 
Tabela 13 - Valores absolutos e percentuais para a distribuição de GRI

\begin{tabular}{|c|c|c|c|}
\hline Valor GRI & Totais absolutos & Totais Percentuais (\%) & Percentuais Acumulados (\%) \\
\hline 0 & 63 & 13,70 & 13,70 \\
\hline 1 & 145 & 31,52 & 45,22 \\
\hline 2 & 136 & 29,57 & 74,78 \\
\hline 3 & 116 & 25,22 & 100,00 \\
\hline
\end{tabular}

Fonte: elaboração própria.

Para as três matérias legislativas sob análise (M3, M4 e M5), foram 1265 votos nominais e 460 deputados votantes que estiveram presentes nas sessões deliberativas onde ocorreram as votações das matérias no Plenário da Câmara dos Deputados.

Da tabela acima, apenas 13,70\% dos deputados (63 deputados) nunca cooperaram com os interesses da Indústria nas três votações, votando sempre favoravelmente aos interesses manifestos dos cidadãos. Este conjunto de deputados forma o que se poderia chamar de Bancada dos Cidadãos. O percentual de deputados com maioria dos votos a favor da Indústria (GRI $\geq 2$ ), no conjunto das três matérias, corresponde a 54,78\%. Ou seja, a maioria dos deputados votou mais vezes a favor dos interesses da Indústria. $\mathrm{O}$ percentual de deputados que sempre votaram favoravelmente aos interesses da Indústria em todas as votações foi de $34,13 \%$, correspondendo a 157 deputados. Este conjunto de deputados forma o que se poderia chamar de Bancada da Indústria.

Para tentar identificar alguma relação entre o Grau de Responsividade à Indústria (GRI) e as variáveis independentes PI, PJ e PD - proporção das doações que veio de empresas do setor indústria, proporção das doações oriundas de pessoas jurídicas em geral e proporção das doações em relação ao total arrecadado pelos candidatos eleitos em 2014, respectivamente -, foram analisados os percentuais de deputados pertencentes às duas bancadas - da Indústria e dos cidadãos - para as faixas de $80 \%, 75 \%$ e $70 \%$ (faixa com elevados percentuais) e $30 \%, 25 \%$ e $20 \%$ (faixa com baixos percentuais) de PI e PJ. A Tabela 14 resume os resultados. 
Tabela 14 - Análise das bancadas para faixas de PI e PJ.

\begin{tabular}{|c|c|c|c|c|c|c|c|}
\hline \multicolumn{8}{|c|}{ Análise para faixas de PI } \\
\hline Corte & Total Deputados & \multicolumn{2}{|c|}{ Dep. B. Cidadão } & \multicolumn{2}{|c|}{ Dep. B. Indústria } & Relação & Média Relação \\
\hline $80 \%$ & 13 & 1 & $8 \%$ & 3 & $23 \%$ & 3,0 & \multirow[t]{3}{*}{3,2} \\
\hline $75 \%$ & 19 & 2 & $11 \%$ & 6 & $32 \%$ & 3,0 & \\
\hline $70 \%$ & 28 & 3 & $11 \%$ & 11 & $39 \%$ & 3,7 & \\
\hline Corte & Total Deputados & \multicolumn{2}{|c|}{ Dep. B. Cidadão } & \multicolumn{2}{|c|}{ Dep. B. Indústria } & Relação & Média Relação \\
\hline $20 \%$ & 215 & 33 & $15 \%$ & 69 & $32 \%$ & 2,1 & \multirow[t]{3}{*}{2,1} \\
\hline $25 \%$ & 256 & 41 & $16 \%$ & 85 & $33 \%$ & 2,1 & \\
\hline $30 \%$ & 278 & 43 & $15 \%$ & 92 & $33 \%$ & 2,1 & \\
\hline \multicolumn{8}{|c|}{ Análise para faixas de PJ } \\
\hline Corte & Total Deputados & \multicolumn{2}{|c|}{ Dep. B. Cidadão } & \multicolumn{2}{|c|}{ Dep. B. Indústria } & Relação & Média Relação \\
\hline $80 \%$ & 174 & 16 & $9 \%$ & 65 & $37 \%$ & 4,1 & \multirow[t]{3}{*}{3,9} \\
\hline $75 \%$ & 202 & 20 & $10 \%$ & 74 & $37 \%$ & 3,7 & \\
\hline $70 \%$ & 231 & 22 & $10 \%$ & 85 & $37 \%$ & 3,9 & \\
\hline Corte & Total Deputados & \multicolumn{2}{|c|}{ Dep. B. Cidadão } & \multicolumn{2}{|c|}{ Dep. B. Indústria } & Relação & Média Relação \\
\hline $20 \%$ & 54 & 12 & $22 \%$ & 12 & $22 \%$ & 1,0 & \multirow[t]{3}{*}{1,0} \\
\hline $25 \%$ & 61 & 14 & $23 \%$ & 14 & $23 \%$ & 1,0 & \\
\hline $30 \%$ & 71 & 17 & $24 \%$ & 18 & $25 \%$ & 1,1 & \\
\hline
\end{tabular}

Fonte: elaboração própria.

A análise para PI indica que a relação entre o percentual de deputados da Bancada da Indústria e o percentual de deputados da Bancada dos Cidadãos é de 2,1 vezes para percentuais mais baixos de PI (30\%, 25\% e 20\%). Esta relação sobe para uma média de 3,2 para percentuais mais altos de PI (80\%, 75\% e 70\%). Em outras palavras, percentualmente, há $\underline{\mathbf{3 , 2} 2 \text { vezes }}$ mais deputados da Bancada da Indústria entre os deputados que receberam as maiores cifras de recursos financeiros de empresas do setor industrial.

A análise para PJ mostra que o percentual de deputados da Bancada da Indústria é o mesmo percentual de deputados da Bancada dos Cidadãos (Relação=1) para percentuais mais baixos de PJ (30\%, 25\% e 20\%). Esta relação entre o percentual de deputados da Bancada da Indústria e o percentual de deputados da Bancada dos Cidadãos é, em média, de 3,9 vezes para percentuais mais altos de PJ (80\%, 75\% e 70\%). Em outras palavras,

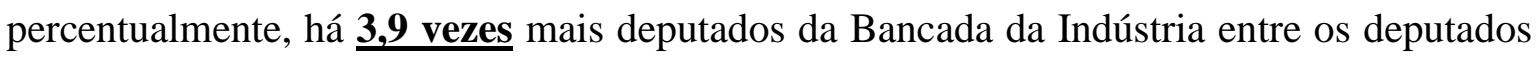
que receberam as maiores cifras de recursos financeiros de empresas em geral. 
Portanto, entre os deputados que receberam os maiores percentuais de recursos financeiros advindos do mercado, existem, em média, aproximadamente 4 (quatro) vezes mais deputados pertencentes à Bancada da Indústria (composta por deputados que nunca votaram a favor dos interesses dos cidadãos) do que deputados pertencentes à Bancada dos Cidadão (composta por deputados que sempre votaram favoravelmente aos cidadãos).

Adicionalmente, para tentar identificar alguma relação entre o GRI e as variáveis independentes PI, PJ e PD, foram plotadas as curvas de dispersão (Scatterplot) da variável dependente GRI em função de cada variável independente (Figura 19).

Figura 19 - Gráficos de dispersão para GRI

(a) GRI x PI

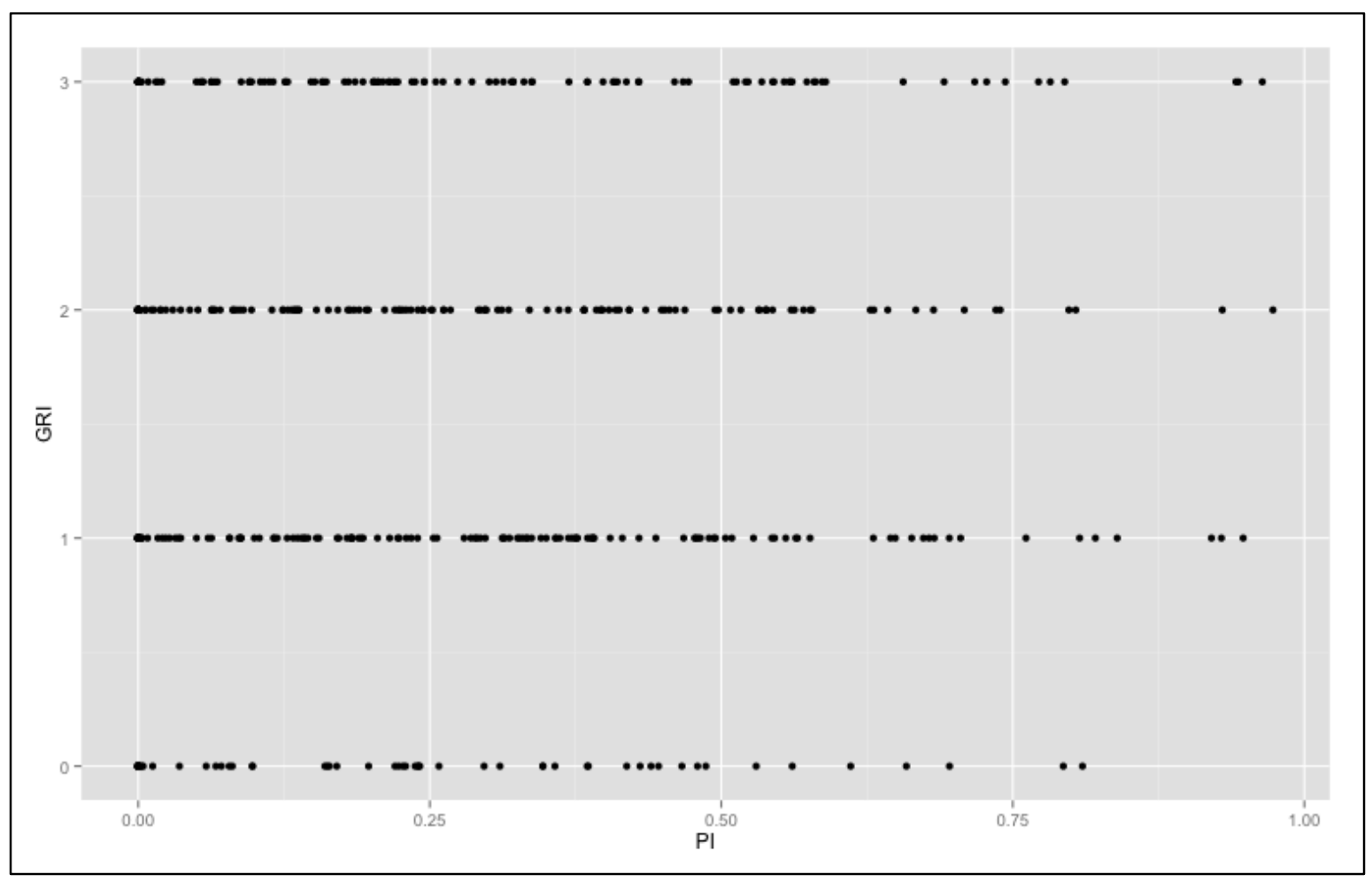

(b) GRI x PJ 


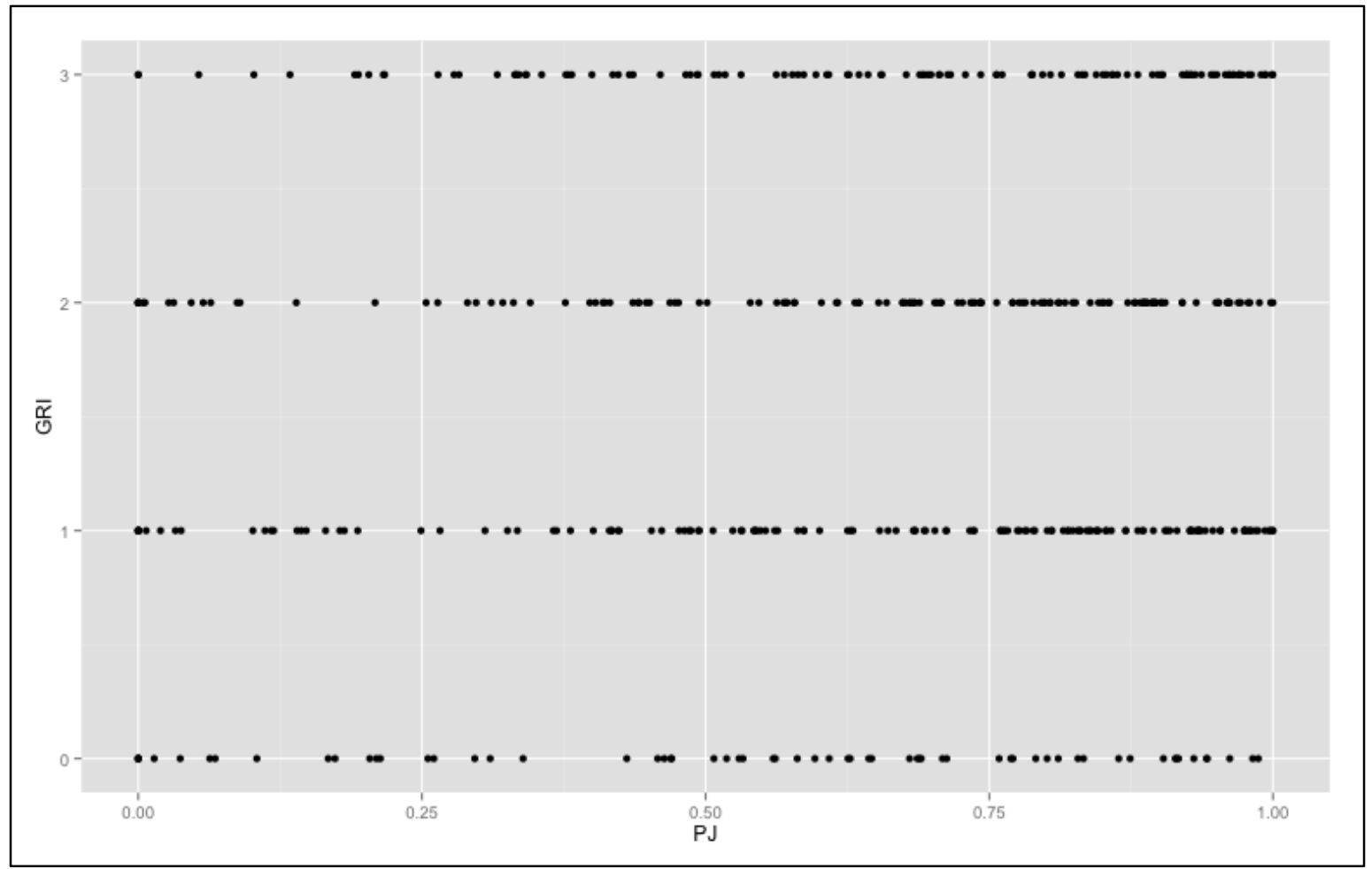

(c) GRI x PD

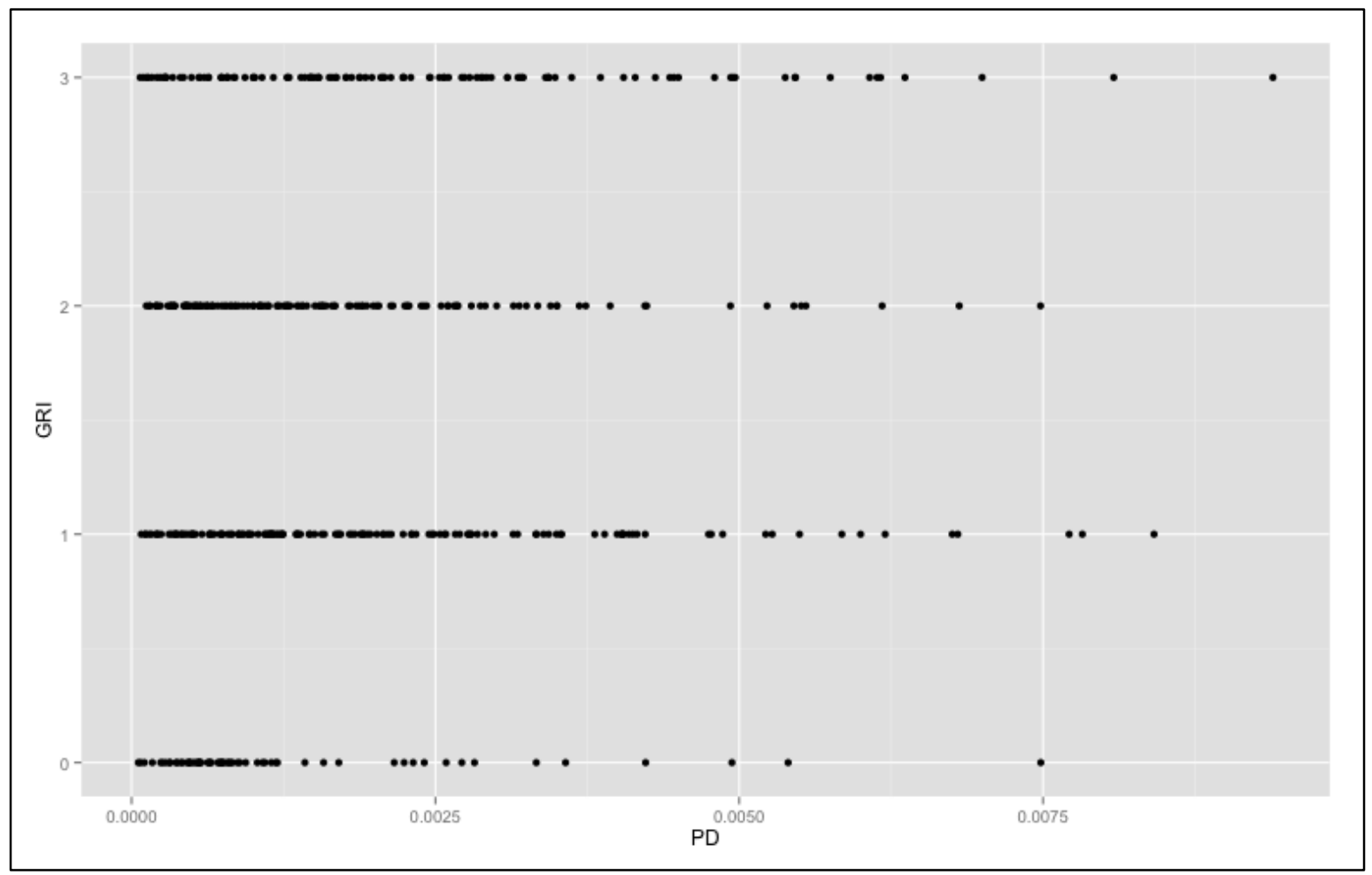

Fonte: elaboração própria. 
Pelo gráfico da Figura 19(a) não é possível identificar uma relação direta e positiva entre a proporção das doações oriundas de empresas ligadas ao setor industrial e o número de vezes que o deputado votou a favor dos interesses da Indústria (CNI). A maior concentração de votos favoráveis à Indústria está para valores de PI entre 0 e 0,5, ou seja, para deputados com proporções das doações oriundas de empresas do setor industrial entre $0 \%$ e 50\%. Para a faixa de PI entre $50 \%$ e $100 \%$, o gráfico mostra uma menor concentração de votos favoráveis à Indústria, se comparado à primeira faixa entre $0 \% \mathrm{e}$ $50 \%$. Esse resultado contraria a suspeita de que o grau de responsividade à Indústria (GRI) dos deputados federais cresceria com o aumento nas proporções de recursos financeiros oriundos de empresas do setor industrial.

O gráfico da Figura 19(b), contudo, indica uma relação direta e positiva entre o grau de responsividade à Indústria e a proporção das doações de campanha advindas de pessoas jurídicas (PJ) em geral, para deputados que votaram pelo menos uma vez favoravelmente à Indústria - 86,31\% dos deputados com GRI $\geq 1$. Neste caso, a maior concentração de votos favoráveis à Indústria encontra-se na faixa de PJ entre 50\% e 100\%. Pode-se concluir, portanto, que quanto maior a proporção das doações recebidas de empresas em geral, há uma tendência de que o deputado vote favoravelmente aos interesses da indústria em um número maior de vezes. Considerando-se que as três matérias legislativas em estudo tratam de questões de interesse comum aos trabalhadores em geral, de todos os setores da economia - contratos de terceirização e as relações de trabalho deles decorrentes (M3), novas regras para concessão do auxílio doença e pensão por morte (M4) e novas regras para concessão do seguro desemprego e do abono salarial (M5) -, é razoável assumir que a posição da CNI representa a posição das empresas em geral, isto é, os interesses do mercado como um todo. Isso explicaria a relação direta e positiva entre PJ e GRI.

Finalmente, pelo gráfico da Figura 19(c) não é possível identificar uma relação direta e positiva entre a proporção das doações em relação ao total arrecadado pelos candidatos eleitos em 2014 (PD) e o grau de responsividade à Indústria (GRI). O resultado apresentado indica que são poucos os deputados com as campanhas eleitorais mais caras (maiores valores de PD) e que votaram mais vezes a favor dos interesses da indústria. Ou seja, um maior volume de recursos arrecadados, proporcionalmente ao total arrecadado nas 
eleições de 2014, parece não implicar em tendência de cooperar um maior número de vezes com a indústria.

A tabela a seguir apresenta os resultados da regressão de Poisson para a variável GRI.

Tabela 15 - Resultados da regressão de Poisson para GRI

\begin{tabular}{|c|c|c|c|c|}
\hline \multirow{4}{*}{ Variável } & \multicolumn{4}{|c|}{ Regressão de Poisson para GRI } \\
\hline & \multicolumn{4}{|c|}{ Matérias M3 a M5, conjuntamente } \\
\hline & GRI vs, $\mathrm{PI}+\mathrm{PJ}+\mathrm{PD}$ & GRI vs, PI & GRI vs, PJ & GRI vs, PD \\
\hline & Modelo 1 & Modelo 2 & Modelo 3 & Modelo 4 \\
\hline Constante & $\begin{array}{c}0,35376^{* * *} \\
(0,09210)\end{array}$ & $\begin{array}{c}0,46084^{* * *} \\
(0,05515)\end{array}$ & $\begin{array}{c}0,37360^{* * *} \\
(0,09124)\end{array}$ & $\begin{array}{c}0,41220 * * * \\
(0,05539)\end{array}$ \\
\hline Proporção doações da indústria (PI) & $\begin{array}{c}0,05802 \\
(0,18657)\end{array}$ & $\begin{array}{c}0,17515 \\
(0,14978)\end{array}$ & & \\
\hline Proporção doações de pessoas jurídicas (PJ) & $\begin{array}{c}0,08673 \\
(0,16752)\end{array}$ & & $\begin{array}{c}0,21049 \\
(0,12887)\end{array}$ & \\
\hline Proporção em rel, total doações deputados (PD) & $\begin{array}{c}41,49742 \\
(21,77969)\end{array}$ & & & $\begin{array}{l}47,98772 * \\
(20,13523)\end{array}$ \\
\hline \multicolumn{5}{|l|}{ Adequação do modelo (Goodness-of-Fit) } \\
\hline LogLikelihood (-2LL) - Null deviance & 363,47 & 363,47 & 363,47 & 363,47 \\
\hline LogLikelihood (-2LL) - Residual deviance & 357,20 & 362,12 & 360,76 & 358,01 \\
\hline Diferença em -2LL & 6,27 & 1,35 & 2,71 & 5,46 \\
\hline Teste Chi-square para mudança em -2LL & 0,098987 & 0,244659 & 0,099807 & 0,019425 \\
\hline
\end{tabular}

Fonte: elaboração própria.

O único resultado estatisticamente significativo foi para o modelo 4 (Teste $C h i$ square < 0,05), indicando uma relação positiva (coeficientes positivos) entre PD e GRI. O gráfico dos valores preditos pelo modelo de regressão de Poisson para a variável GRI indica um comportamento aleatório da variável GRI para valores muito pequenos de PD (Figura 20). Para esses valores, o número de vezes em que os deputados votaram a favor dos interesses da Indústria está próximo de 1,5. Fazendo uma analogia com experimento de lançar uma moeda várias vezes, para valores muito pequenos de PD, em metade das vezes daria "cara" (coopera com a indústria) e na outra metade das vezes daria "coroa" (não coopera com a indústria), o que significa dizer que não se observa tendência ou viés nos resultados para pequenos valores de PD. Contudo, para valores de PD a partir de 0,002 
( $0,2 \%$ do total de todas as doações recebidas) a curva dos valores preditos mostra uma tendência de aumento de GRI à medida que PD aumenta. Significa dizer que para valores crescentes de PD, isto é, quanto mais rica a campanha eleitoral, maior a tendência a votar mais vezes em favor dos interesses da indústria e, consequentemente, contra os interesses dos cidadãos.

Figura 20 - Valores preditos (estimados) de GRI em função de PD

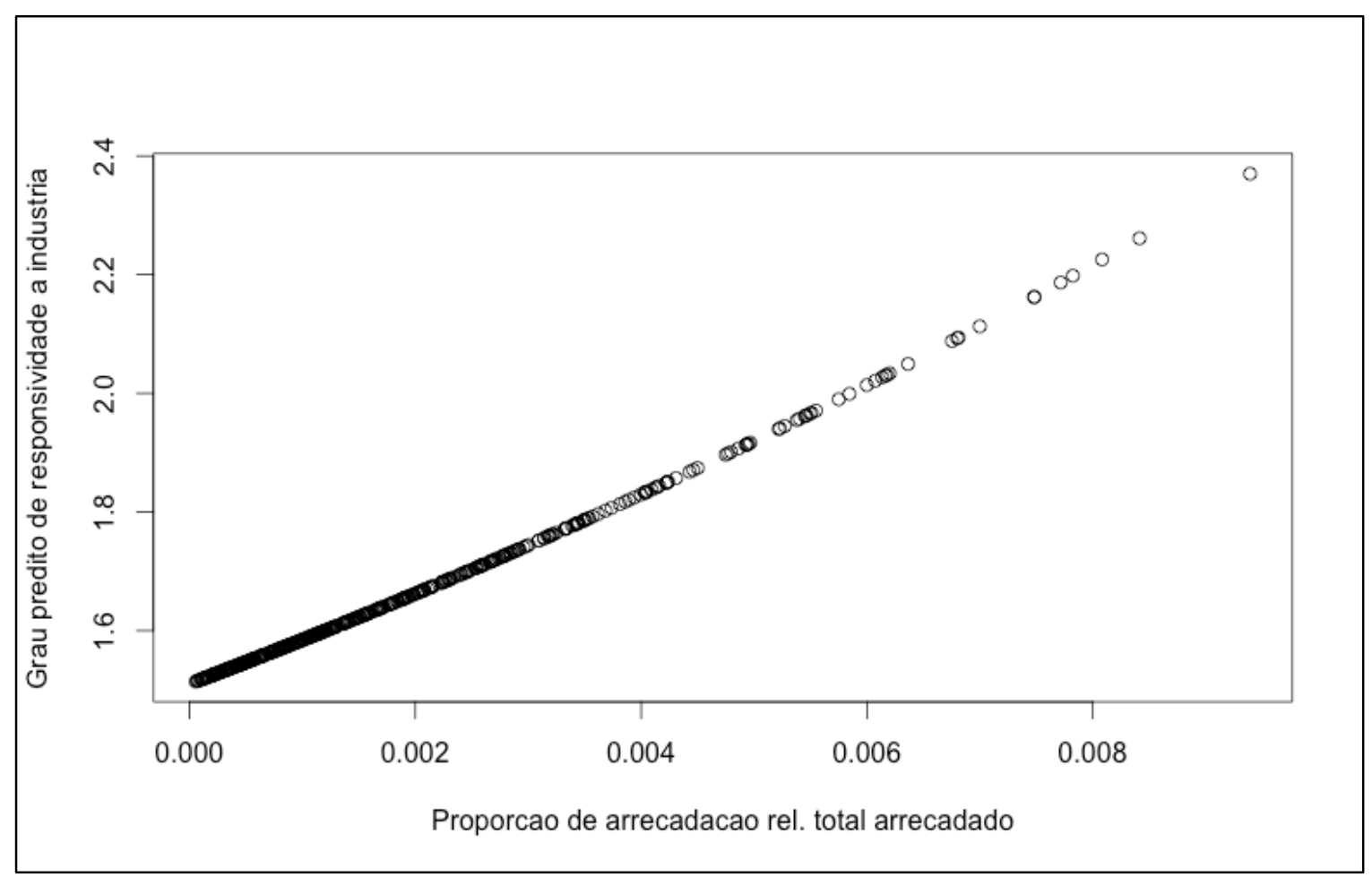

Fonte: elaboração própria.

As tabelas a seguir apresentam os resultados das regressões logísticas para a variável binária RI (Responsividade à Indústria), para as três matérias M3, M4 e M5, tomadas conjuntamente, formando uma série com 1.265 votos (observações) de deputados federais - Tabela 16(a), para o conjunto das três matérias, com 1.265 votos; Tabela 16(b) para a matéria M3, com 416 votos; Tabela 16(c), para a matéria M4, com 415 votos; e Tabela 16(d), para a matéria M5, com 434 votos. 
Tabela 16 - Responsividade à Indústria

(a) Matérias M3+M4+M5.

\begin{tabular}{|c|c|c|c|c|}
\hline \multirow{4}{*}{ Variável } & \multicolumn{4}{|c|}{ Regressão Logística para Responsividade à Indústria (RI) } \\
\hline & \multicolumn{4}{|c|}{ Matérias M3 a M5, conjuntamente } \\
\hline & RI vs. $\mathrm{PI}+\mathrm{PJ}+\mathrm{PD}$ & RI vs. PI & RI vs. PJ & RI vs. PD \\
\hline & Modelo 1 & Modelo 2 & Modelo 3 & Modelo 4 \\
\hline Constante & $\begin{array}{c}0,06721 \\
(0,14274)\end{array}$ & $\begin{array}{c}0,2603 * * \\
(0,0868)\end{array}$ & $\begin{array}{c}0,1112 \\
(0,1401)\end{array}$ & $\begin{array}{l}0,19258^{*} \\
(0,08778)\end{array}$ \\
\hline Proporção doações da indústria (PI) & $\begin{array}{c}0,44647 \\
(0,30673)\end{array}$ & $\begin{array}{c}0,6218^{*} \\
(0,2484)\end{array}$ & & \\
\hline Proporção doações de pessoas jurídicas (PJ) & $\begin{array}{c}0,05538 \\
(0,26535) \\
\end{array}$ & & $\begin{array}{l}0,4962^{*} \\
(0,2028) \\
\end{array}$ & \\
\hline Proporção em rel, total doações deputados (PD) & $\begin{array}{c}107,22309 * * \\
(38,00591)\end{array}$ & & & $\begin{array}{c}122,08945^{* * *} \\
(35,59905)\end{array}$ \\
\hline \multicolumn{5}{|l|}{ Adequação do modelo (Goodness-of-Fit) } \\
\hline LogLikelihood (-2LL) - Null deviance & 1697,70 & 1697,70 & 1697,70 & 1697,70 \\
\hline LogLikelihood (-2LL) - Residual deviance & 1681,70 & 1691,40 & 1691,80 & 1685,40 \\
\hline Diferença em -2LL & 16,000 & 6,300 & 5,900 & 12,300 \\
\hline Teste Chi-square para mudança em -2LL & 0,001112 & 0,011667 & 0,014454 & 0,000451 \\
\hline
\end{tabular}

(b) Matéria M3.

\begin{tabular}{|c|c|c|c|c|}
\hline \multirow{5}{*}{ Variável } & \multicolumn{4}{|c|}{ Regressão Logística para RI } \\
\hline & \multicolumn{4}{|c|}{ Por matéria } \\
\hline & \multicolumn{4}{|c|}{ M3 } \\
\hline & RI vs. $\mathrm{PI}+\mathrm{PJ}+\mathrm{PD}$ & RI vs. PI & RI vs. PJ & RI vs. PD \\
\hline & Modelo 5 & Modelo 6 & Modelo 7 & Modelo 8 \\
\hline Constante & $\begin{array}{c}0,06995 \\
(0,25840) \\
\end{array}$ & $\begin{array}{c}0,6430^{* * *} \\
(0,1591) \\
\end{array}$ & $\begin{array}{c}0,2269 \\
(0,2493)\end{array}$ & $\begin{array}{c}0,3173 . \\
(0,1694)\end{array}$ \\
\hline Proporção doações da indústria (PI) & $\begin{array}{c}0,23068 \\
(0,59426) \\
\end{array}$ & $\begin{array}{l}0,8806 . \\
(0,4771)\end{array}$ & & \\
\hline Proporção doações de pessoas jurídicas (PJ) & $\begin{array}{c}0,41905 \\
(0,49875) \\
\end{array}$ & & $\begin{array}{c}1,0362 * * \\
(0,3720) \\
\end{array}$ & \\
\hline Proporção em rel, total doações deputados (PD) & $\begin{array}{c}273,71884^{* *} \\
(86,59596)\end{array}$ & & & $\begin{array}{c}315,3300 * * * \\
(82,4570)\end{array}$ \\
\hline \multicolumn{5}{|l|}{ Adequação do modelo (Goodness-of-Fit) } \\
\hline LogLikelihood (-2LL) - Null deviance & 505,15 & 505,15 & 505,15 & 505,15 \\
\hline LogLikelihood (-2LL) - Residual deviance & 485,48 & 501,62 & 497,40 & 487,33 \\
\hline Diferença em -2LL & 19,670 & 3,530 & 7,750 & 17,820 \\
\hline Teste Chi-square para mudança em -2LL & 0,000198 & 0,060275 & 0,005374 & 0,000024 \\
\hline
\end{tabular}

(c) Matéria M4. 


\begin{tabular}{|c|c|c|c|c|}
\hline \multirow{5}{*}{ Variável } & \multicolumn{4}{|c|}{ Regressão Logística para RI } \\
\hline & \multicolumn{4}{|c|}{ Por matéria } \\
\hline & \multicolumn{4}{|c|}{ M4 } \\
\hline & RI vs. $\mathrm{PI}+\mathrm{PJ}+\mathrm{PD}$ & RI vs. PI & RI vs. PJ & RI vs. PD \\
\hline & Modelo 9 & Modelo 10 & Modelo 11 & Modelo 12 \\
\hline Constante & $\begin{array}{c}0,3825 \\
(0,2512)\end{array}$ & $\begin{array}{c}0,2473 \\
(0,1514)\end{array}$ & $\begin{array}{c}0,37484 \\
(0,24726)\end{array}$ & $\begin{array}{l}0,3089 * \\
(0,1501)\end{array}$ \\
\hline Proporção doações da indústria (PI) & $\begin{array}{c}0,7811 \\
(0,5288)\end{array}$ & $\begin{array}{c}0,5154 \\
(0,4285)\end{array}$ & & \\
\hline Proporção doações de pessoas jurídicas (PJ) & $\begin{array}{l}-0,4689 \\
(0,4621)\end{array}$ & & $\begin{array}{c}0,01661 \\
(0,35502)\end{array}$ & \\
\hline Proporção em rel, total doações deputados (PD) & $\begin{array}{c}48,0140 \\
(63,2491)\end{array}$ & & & $\begin{array}{r}39,8766 \\
(58,6812) \\
\end{array}$ \\
\hline \multicolumn{5}{|l|}{ Adequação do modelo (Goodness-of-Fit) } \\
\hline LogLikelihood (-2LL) - Null deviance & 560,18 & 560,18 & 560,18 & 560,18 \\
\hline LogLikelihood (-2LL) - Residual deviance & 557,47 & 558,72 & 560,18 & 559,72 \\
\hline Diferença em -2LL & 2,710 & 1,460 & 0,000 & 0,460 \\
\hline Teste Chi-square para mudança em -2LL & 0,437664 & 0,226532 & 0,962690 & 0,494776 \\
\hline
\end{tabular}

(d) Matéria M5.

\begin{tabular}{|c|c|c|c|c|}
\hline \multirow{5}{*}{ Variável } & \multicolumn{4}{|c|}{ Regressão Logística para RI } \\
\hline & \multicolumn{4}{|c|}{ Por matéria } \\
\hline & \multicolumn{4}{|c|}{ M5 } \\
\hline & RI vs. $\mathrm{PI}+\mathrm{PJ}+\mathrm{PD}$ & RI vs. PI & RI vs. PJ & RI vs. PD \\
\hline & Modelo 13 & Modelo 14 & Modelo 15 & Modelo 16 \\
\hline Constante & $\begin{array}{c}-0,2996 \\
(0,2429)\end{array}$ & $\begin{array}{c}-0,08925 \\
(0,14683)\end{array}$ & $\begin{array}{c}-0,2694 \\
(0,2393)\end{array}$ & $\begin{array}{c}-0,1192 \\
(0,1475)\end{array}$ \\
\hline Proporção doações da indústria (PI) & $\begin{array}{c}0,3795 \\
(0,5079) \\
\end{array}$ & $\begin{array}{c}0,60335 \\
(0,41198) \\
\end{array}$ & & \\
\hline Proporção doações de pessoas jurídicas (PJ) & $\begin{array}{c}0,1832 \\
(0,4473) \\
\end{array}$ & & $\begin{array}{c}0,5382 \\
(0,3435) \\
\end{array}$ & \\
\hline Proporção em rel, total doações deputados (PD) & $\begin{array}{c}78,1176 \\
(61,1916) \\
\end{array}$ & & & $\begin{array}{r}97,9513 \\
(57,1413) \\
\end{array}$ \\
\hline \multicolumn{5}{|l|}{ Adequação do modelo (Goodness-of-Fit) } \\
\hline LogLikelihood (-2LL) - Null deviance & 601,06 & 601,06 & 601,06 & 601,06 \\
\hline LogLikelihood (-2LL) - Residual deviance & 596,48 & 598,90 & 598,59 & 598,06 \\
\hline Diferença em -2LL & 4,580 & 2,160 & 2,470 & 3,000 \\
\hline Teste Chi-square para mudança em -2LL & 0,204863 & 0,141394 & 0,116151 & 0,083423 \\
\hline
\end{tabular}

Fonte: elaboração própria.

Os resultados estatisticamente significativos foram para os modelos 2 e 4 (Tabela 16(a)) e modelo 8 (Tabela 16(b)). A Figura 21 apresenta a probabilidade estimada pelo modelo 2 do deputado cooperar (ser responsivo) com a Indústria, em função da proporção das doações recebidas de empresas do setor industrial (PI).

Um valor de probabilidade acima de 0,5 significa que o modelo de regressão logística classifica o caso como "coopera com a indústria". Como todos os valores de 
probabilidade estão acima de 0,5 , significa que o modelo classificou todos os casos como um caso em que o deputado coopera com a indústria. A Figura 17 mostrou que em $60 \%$ dos casos observados os deputados cooperaram com a Indústria (RI=1) e em $40 \%$ dos casos os deputados cooperaram com os cidadãos $(\mathrm{RI}=0)$. Como o modelo de regressão logística classificou $100 \%$ dos casos como casos em que os deputados cooperam com a indústria, o percentual de acerto do modelo é de $60 \%$.

Esse mesmo resultado é obtido analisando-se a tabela de classificação para o modelo 2:

Tabela 17 - Tabela de classificação para modelo 2 (M3 + M4 + M5)

\begin{tabular}{|c|c|c|c|}
\hline \multirow{2}{*}{ Valor observado } & \multicolumn{3}{|c|}{ Valor predito } \\
\cline { 2 - 4 } & Não coopera com indústria & Coopera com indústria & Total \\
\hline Não coopera com indústria & 0 & 500 & 500 \\
\hline Coopera com indústria & 0 & 765 & 765 \\
\hline TOTAL & 0 & 1265 & 1265 \\
\hline
\end{tabular}

Fonte: elaboração própria.

Da tabela, o percentual de acerto do modelo 2 é de $(765 / 1265) * 100=60,47 \%$.

A curva da Figura 21 também mostra uma relação crescente entre a probabilidade de cooperação com a indústria e PI. Ou seja, a probabilidade dos deputados em cooperar com a indústria cresce proporcionalmente com o aumento de PI. Portanto, quanto maior a proporção das doações advindas de empresas do setor industrial, maior também a probabilidade de cooperar com a indústria (e não cooperar com os cidadãos). 
Figura 21 - Probabilidade de cooperação com a Indústria em função de PI

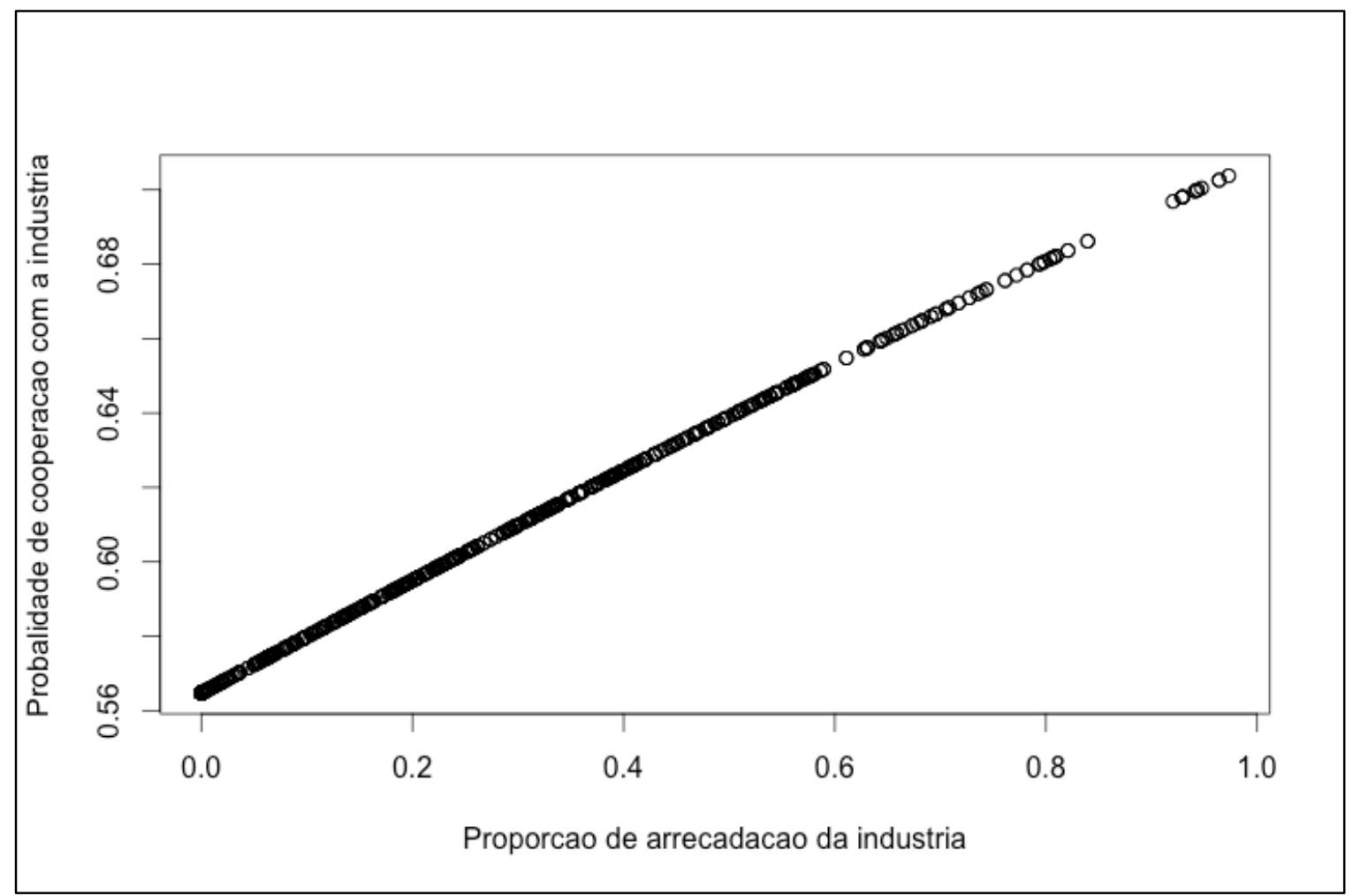

Fonte: elaboração própria.

A Figura 22 apresenta a probabilidade estimada pelo modelo 4 do deputado cooperar (ser responsivo) com a Indústria, em função da proporção das doações em relação ao total arrecadado pelos candidatos eleitos em 2014 (PD).

De forma similar ao gráfico da Figura 21, todos os valores de probabilidade estão acima de 0,5 , o que significa que o modelo classificou todos os casos como casos em que o deputado coopera com a indústria. Da mesma maneira, como os valores observados de RI mostram que em 60\% dos casos os deputados cooperaram com a Indústria (RI=1) e em $40 \%$ dos casos não, e o modelo de regressão logística classificou $100 \%$ dos casos como casos em que os deputados cooperam com a indústria, o percentual de acerto do modelo é de $60 \%$.

A curva da Figura 22 mostra uma relação crescente entre a probabilidade de cooperação com a indústria e PD. A probabilidade dos deputados em cooperar com a 
indústria cresce proporcionalmente com o aumento de PD. Portanto, quanto maior a proporção das doações em relação ao total arrecadado ou, em outras palavras, quanto mais cara a campanha eleitoral, maior a probabilidade de cooperar com a indústria (e não cooperar com os cidadãos).

Figura 22 - Probabilidade de cooperação com a Indústria em função de PD

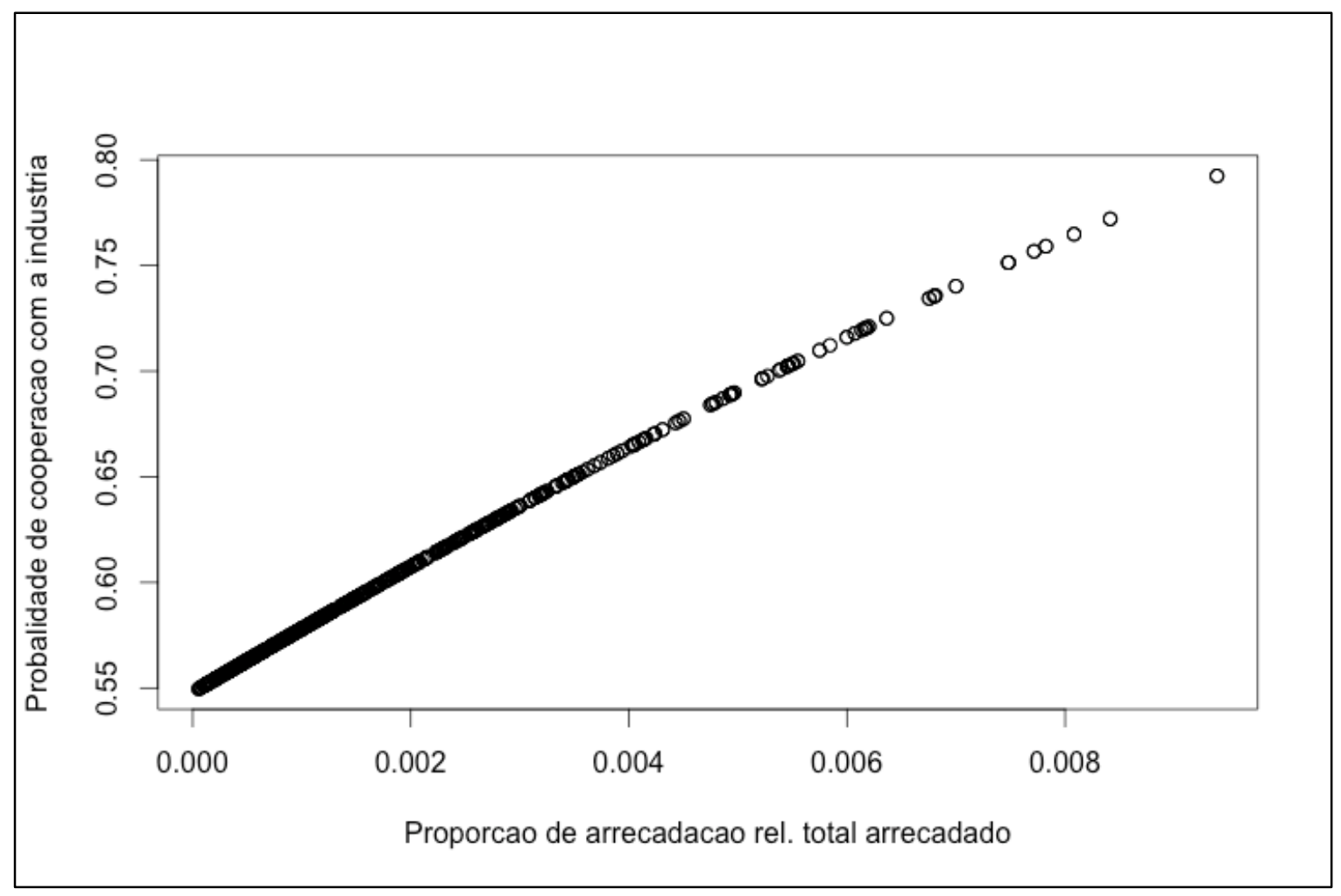

Fonte: elaboração própria.

A Figura 23 apresenta a probabilidade estimada pelo modelo 8 (com votos nominais apenas para a matéria M3) do deputado cooperar (ser responsivo) com a Indústria, em função da proporção das doações em relação ao total arrecadado pelos candidatos eleitos (PD).

De forma similar à curva da Figura 22, todos os valores de probabilidade estão acima de 0,5 , o que significa que o modelo classificou todos os casos como casos em que o deputado coopera com a indústria. Considerando-se um ponto de corte de 0,5 , tem-se a seguinte tabela de classificação do modelo 8: 
Tabela 18 - Tabela de classificação para modelo 8 (M3)

\begin{tabular}{|c|c|c|c|}
\hline \multirow{2}{*}{ Valor observado } & \multicolumn{3}{|c|}{ Valor predito } \\
\cline { 2 - 4 } & Não coopera com indústria & Coopera com indústria & Total \\
\hline Não coopera com indústria & 0 & 123 & 123 \\
\hline Coopera com indústria & 0 & 293 & 293 \\
\hline TOTAL & 0 & 416 & 416 \\
\hline
\end{tabular}

Fonte: elaboração própria.

Da tabela, o percentual de acerto do modelo é de $(293 / 416) * 100=70,43 \%$.

A curva da Figura 23 mostra uma relação crescente entre a probabilidade de cooperação com a indústria e PD ao analisar os votos dos deputados apenas para a matéria M3, que trata de contratos de terceirização. A probabilidade dos deputados em cooperar com a indústria cresce proporcionalmente com o aumento de PD, porém a taxas superiores em relação à curva da Figura 22. A escala de variação das probabilidades preditas para o modelo 8 apresenta valores mínimos e máximos superiores aos apresentados pela Figura 21 (análise da responsividade para o conjunto das três matérias M3, M4 e M5). No caso da curva da Figura 23, a probabilidade chega próximo de 1 para o deputado com a campanha mais cara.

Portanto, quando se analisa os votos apenas para a matéria M3, a curva das probabilidades mostra que quanto maior a proporção das doações em relação ao total arrecadado ou, em outras palavras, quanto mais cara a campanha eleitoral, maior a probabilidade do deputado cooperar com a indústria (e não cooperar com os cidadãos), sendo que a probabilidade cresce mais rapidamente e atinge valores superiores quando comparada às probabilidades apresentadas pelos modelos 2 e 4 para 0 conjunto das matérias. 
Figura 23 - Probabilidade de cooperação com a Indústria em função de PD, para M3.

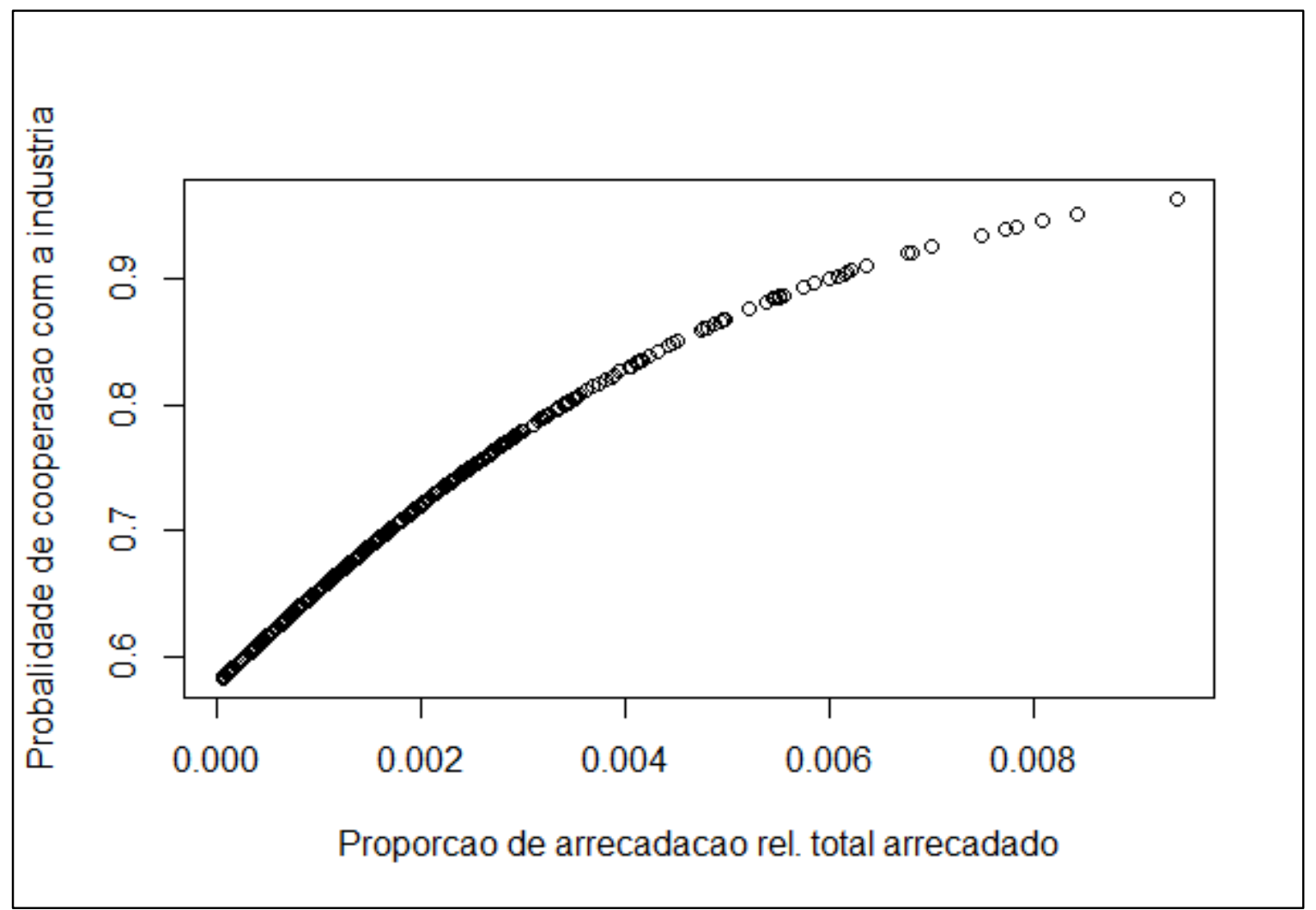

Fonte: elaboração própria.

Os resultados obtidos na análise quantitativa são resumidos da seguinte forma:

- No conjunto das três matérias legislativas, totalizando 1265 votos, em $60 \%$ dos casos os deputados cooperaram com a Indústria e em $40 \%$ dos casos os deputados cooperaram com os cidadãos.

- A maioria dos deputados $(54,78 \%)$ votou mais vezes a favor dos interesses da Indústria do que a favor dos interesses dos cidadãos.

- A "Bancada dos Cidadãos" é composta por 63 deputados $(13,70 \%)$ que sempre votaram favoravelmente aos interesses dos cidadãos.

- A "Bancada da Indústria" é composta por 157 deputados $(34,13 \%$,) que sempre votaram favoravelmente aos interesses da Indústria, que para as matérias selecionadas, é representativo do interesse do mercado em geral. 
- Entre os deputados que receberam os maiores percentuais de recursos financeiros advindos do mercado, existem, em média, aproximadamente $\underline{4}$ (quatro) vezes mais deputados pertencentes à Bancada da Indústria do que deputados pertencentes à Bancada dos Cidadãos.

- Para os deputados que votaram pelo menos uma vez favoravelmente aos interesses da Indústria (86,31\% dos deputados), quanto maior a proporção das doações recebidas de empresas em geral, os deputados tendem a cooperar mais vezes com a Indústria.

- Quanto maior a proporção das doações advindas de empresas do setor industrial, maior a probabilidade de cooperar com a indústria e, portanto, de não cooperar com os cidadãos.

- Quanto mais cara a campanha eleitoral, maior a probabilidade de cooperar com a indústria e, portanto, de não cooperar com os cidadãos.

- Para a matéria que trata de contratos de terceirização, quanto mais cara a campanha eleitoral, maior a probabilidade de cooperar com a indústria (e não cooperar com os cidadãos). Neste caso, a probabilidade cresce mais rapidamente para aumentos na proporção de doações em relação ao total arrecadado.

Pelos resultados apresentados, fica evidente que, em geral, e para as matérias legislativas analisadas, a responsividade dos deputados está significativamente direcionada às preferências e interesses do mercado e não às preferências e interesses dos cidadãos.

\section{Efeitos de socialização e psicológicos}

Em complemento à análise quantitativa sobre a responsividade dos parlamentares (pesquisa extensiva), este capítulo traz os principais resultados de uma pesquisa de natureza qualitativa (pesquisa intensiva) sobre os efeitos de socialização e psicológicos da participação popular. Os principais efeitos investigados são (1) a autopercepção da capacidade de agir dos cidadãos e (2) a percepção dos cidadãos em relação à 
responsividade dos parlamentares. Através da aplicação de um questionário próprio, procurou-se conhecer a percepção dos cidadãos sobre, primeiro, a eficácia de sua participação política através do portal e-Democracia da Câmara dos Deputados e, em segundo lugar, sobre a responsividade dos deputados federais em relação às suas demandas.

Foram enviadas mensagens por correio eletrônico a 380 pessoas cadastradas no portal e-Democracia, explicando a pesquisa e solicitando o preenchimento do questionário, sendo obtidas 43 respostas. A tabela com a íntegra das respostas ao questionário encontrase no Apêndice II.

\subsection{Autopercepção da capacidade de agir dos cidadãos}

A pergunta do questionário relativa à eficácia da participação foi: "Você acha que sua participação no portal e-Democracia serviu para influenciar a atuação de um ou mais deputados?". Os gráficos a seguir resumem os resultados para a pergunta.

Figura 24 - Autopercepção da eficácia da participação

(a) 


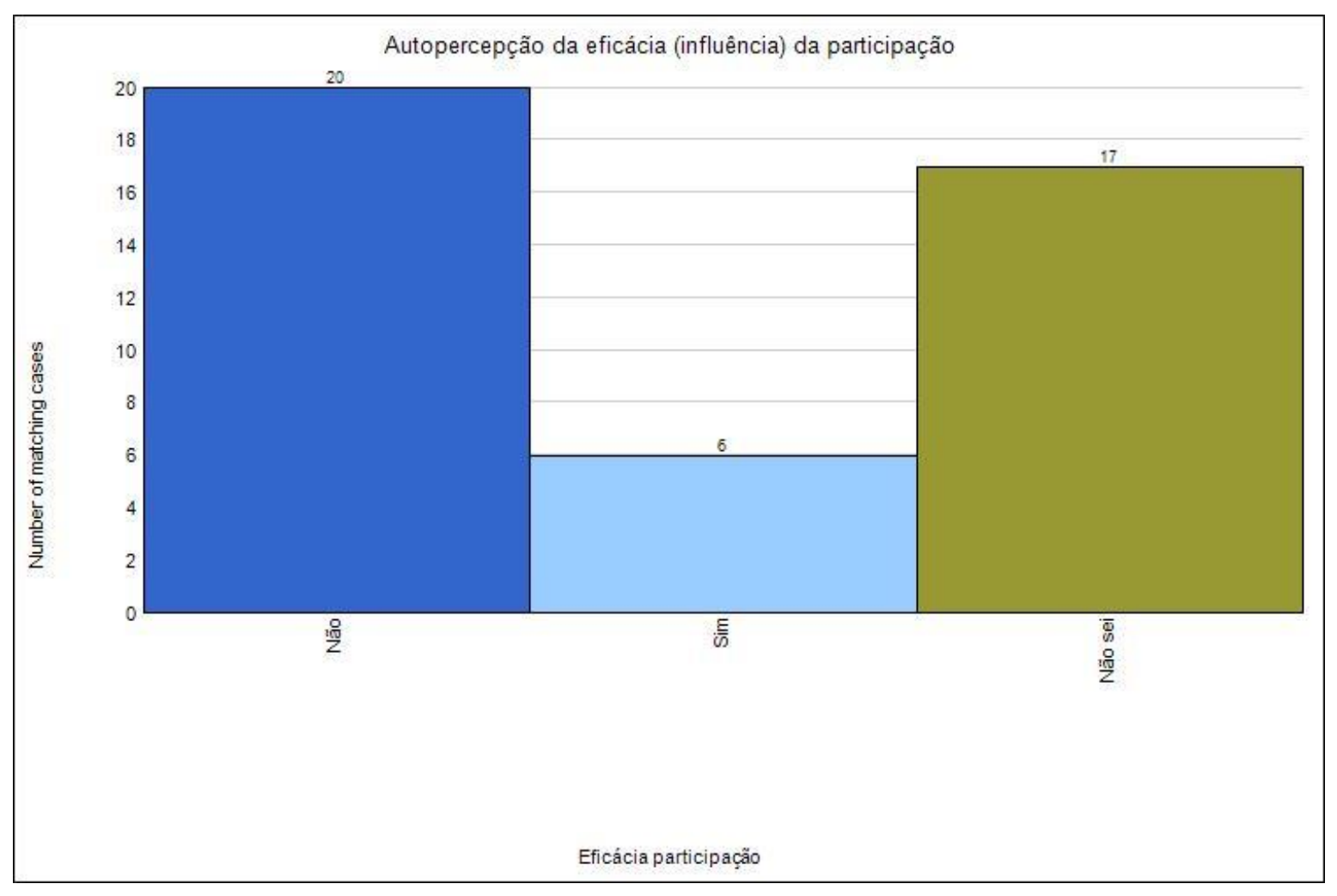

(b)

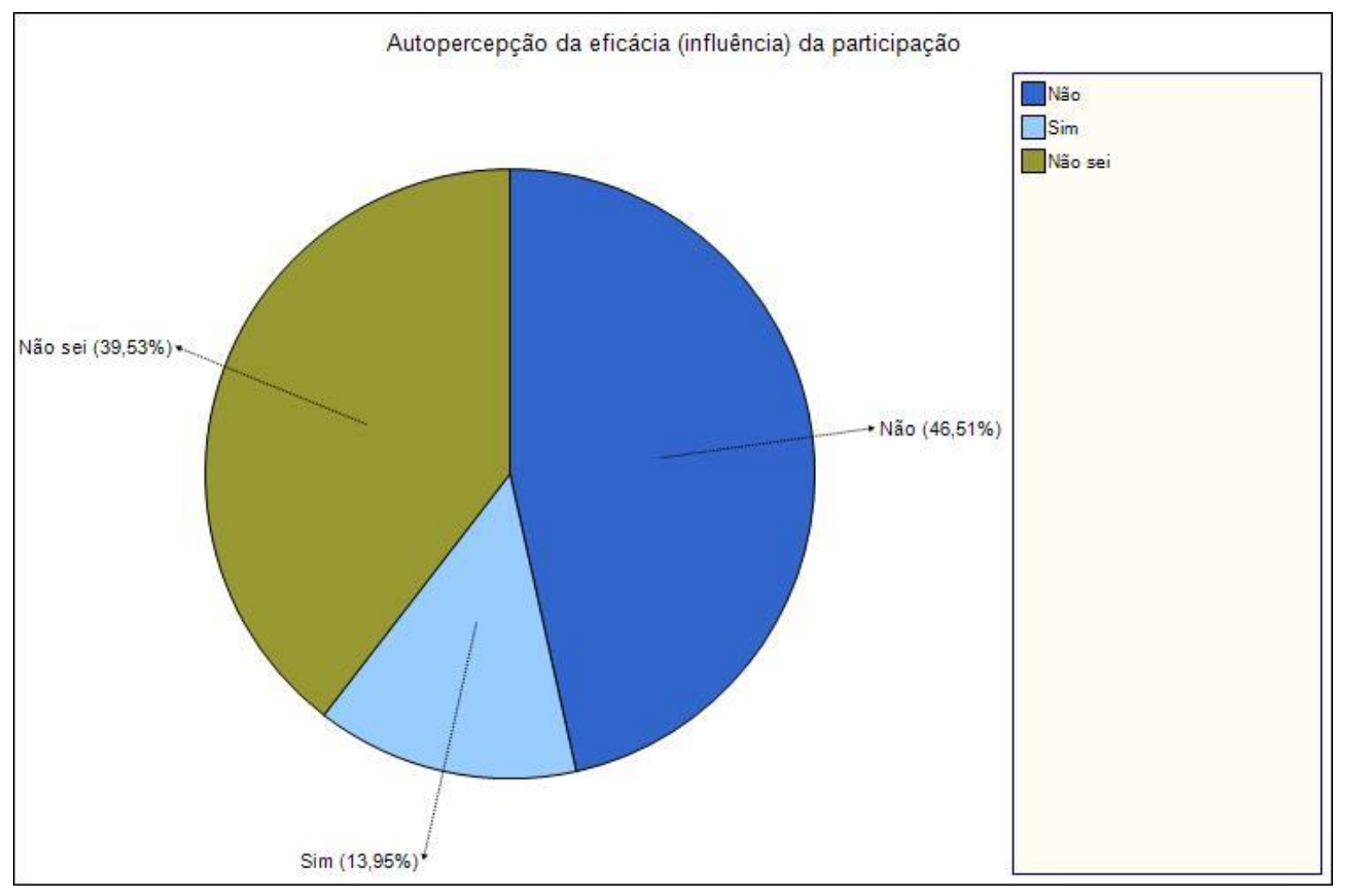

Fonte: elaboração própria. 
Os gráficos mostram que para 46,51\% dos respondentes, sua participação no portal e-Democracia não conseguiu influenciar a atuação dos deputados. 39,53\% dos respondentes não tem certeza se sua participação contribuiu para influenciar o comportamento dos parlamentares, e apenas $13,95 \%$ dos respondentes acreditam que sua participação no e-Democracia influenciou a atuação de pelo menos um deputado. Uma maioria expressiva $(86,04 \%)$ ou não sabe ao certo sobre a eficácia de sua participação, ou estão convictos de que não conseguiram influenciar o comportamento dos deputados federais. Este resultado aponta para uma percepção geral, por parte dos cidadãos, de uma baixa efetividade da participação popular, em termos da capacidade de influenciar o corpo político na Câmara dos Deputados.

Considerando que a participação sociodigital, e a participação política em geral, é um fenômeno complexo que envolve uma multiplicidade de atores e variáveis de contexto, é provável que existam um conjunto de fatores que expliquem essa percepção dos cidadãos de uma baixa efetividade de sua participação. Um desses fatores é a falta de retorno ou resposta dos deputados às demandas e manifestações dos cidadãos pelos canais institucionais de interação com a sociedade, o que fica evidente nas respostas à seguinte pergunta do questionário: "Você recebeu alguma resposta (retorno) da sua contribuição ou manifestação no portal e-Democracia da Câmara dos Deputados?” (Figura 25). 
Figura 25 - Cidadãos que receberam resposta às suas manifestações

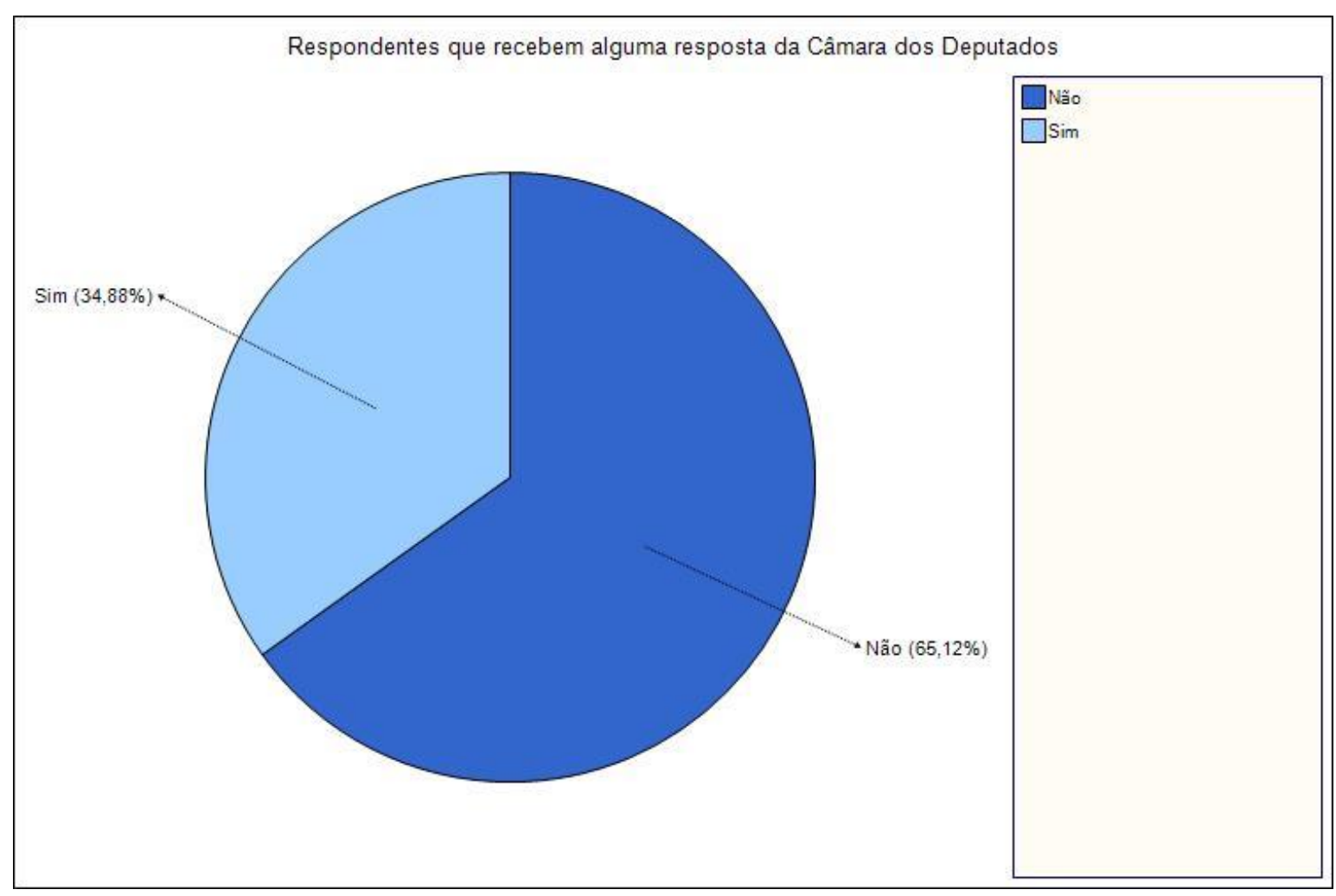

Fonte: elaboração própria.

Pelo gráfico, $65,12 \%$ dos respondentes declararam não ter recebido nenhuma resposta às suas manifestações no portal e-Democracia. Certamente, este fato contribuiu para uma avaliação negativa sobre a efetividade da participação.

Na mesma direção dos resultados obtidos com o questionário, um dos entrevistados afirmou o seguinte: "Porque a gente tem percebido que ainda depois de seis anos de eDemocracia, ainda é bastante residual a participação dos deputados na nossa plataforma. A gente tem pouco mais de $10 \%$ dos deputados nesse período participando. Então, o que a gente quer é facilitar essa interação”. A declaração ganha ainda maior relevância quando consideramos que o entrevistado integra a equipe de gestão do portal e-Democracia e, portanto, tem conhecimento privilegiado sobre seu funcionamento e utilização. Por que a participação dos deputados no e-Democracia tem sido residual? A proposição básica da presente tese é a de que, em geral, a responsividade dos deputados está direcionada muito mais aos interesses dos seus doadores de campanha, especialmente aos doadores empresariais, do que aos interesses dos cidadãos, e isso é, precisamente, uma das principais 
causas de uma participação residual dos deputados nos espaços de interação Parlamentosociedade, instituídos pela Câmara dos Deputados.

Outro entrevistado, igualmente membro da equipe responsável pela gestão de vários canais de interação da Câmara dos Deputados com a sociedade, ao tratar do serviço Fale com o Deputado, afirma:

"Então, criou-se o canal Fale com o Deputado. A Câmara entendeu que precisava dizer à sociedade que ela pode interagir com o deputado. Só que o deputado, na realidade prática, ele não organiza uma equipe, um fluxo de trabalho, pra atender as demandas dos cidadãos que, inclusive, foram estimulados a participar por meio desse canal. Então gera um déficit, um gargalo, que não é resolvido e o cidadão fica sem resposta. $\mathbf{O}$ pior sinal possível pra sociedade é você dizer que os canais estão obstruídos ou fechados, ou então abertos só no papel. Na hora que você desperta pra exercer a sua cidadania, você não obtém retorno. Então, como a Casa foi vendo isso de uma forma recorrente, a postura dos parlamentares era, no padrão, não responder, aí a gente passou a transferir. Foi transferido para o 0800 essa atribuição de receber os atendimentos em primeiro nível... o papel do 0800 é dizer que foi recebido, dizer que não caiu no vazio. Que foi recebido e que foi encaminhado para o setor correspondente. Então há esse tipo de retorno inicial que a própria equipe do 0800 faz com o cidadão.

Agora como a equipe do 0800 não é o destinatário final da mensagem final e não pode responder em nome do parlamentar, é o nosso nível limitado de ação, mas pelo menos para não ficar tão feio a gente interfere nessa etapa intermediaria. E isso acontece com o Fale com o Presidente, com o Fale com o Deputado, e com o Fale com a Ouvidoria"

É possível concluir, pelo seguinte trecho da narrativa do entrevistado - “... o deputado, na realidade prática, ele não organiza uma equipe, um fluxo de trabalho, pra atender as demandas dos cidadãos" - que, em geral, os deputados não investem esforços para responder às demandas dos cidadãos que chegam à Câmara pelos diversos canais de interação - Fale com o Deputado, Fale com o Presidente e Fale com a Ouvidoria, por exemplo. 
O entrevistado, ao dizer que "o pior sinal possível pra sociedade é você dizer que os canais estão obstruídos ou fechados, ou então abertos só no papel”, ventila a possibilidade de que as iniciativas de participação, inclusive as que se utilizam intensivamente das novas Tecnologias de Informação e Comunicação (TICs), tornem-se inefetivas, quando os canais com a sociedade apenas simulam uma abertura, permanecendo, em verdade, obstruídos.

Em geral, os autores que estudam a participação política destacam o papel educativo da participação. Noções como "escola da cidadania" estariam associadas à máxima de que "participação gera mais participação". Entretanto, quando o esforço do cidadão em participar do processo político não vem acompanhado dos sinais de que sua voz está sendo ouvida pelos representantes eleitos, a participação, ou mais precisamente a interação com vistas à participação, transforma-se em desestímulo a futuros esforços de participação por parte do cidadão. Vale lembrar que, em geral, participar da vida pública envolve custos significativos para o cidadão comum, em termos de tempo e custos de aquisição de informação e de "estar presente" nos espaços de deliberação política. Talvez essa experiência negativa em participar explique a baixa recorrência dos respondentes na utilização do portal e-Democracia, fato evidenciado nas respostas dos cidadãos sobre a regularidade com que utilizam o canal e-Democracia (Figura 26). 
Figura 26 - Regularidade de utilização do e-Democracia

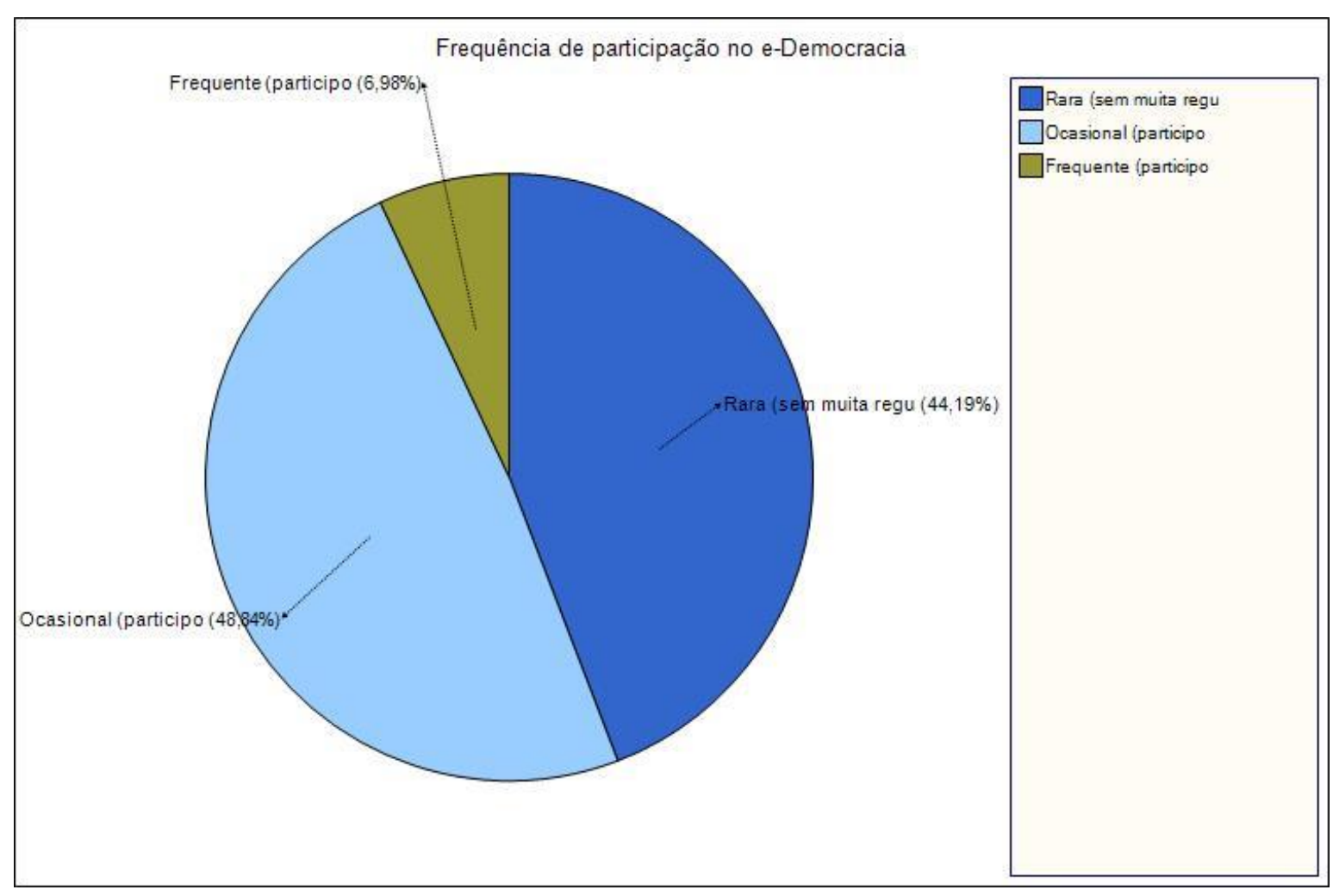

Fonte: elaboração própria.

As respostas mostram que $44,19 \%$ dos respondentes considera rara (sem muita regularidade) sua participação no e-Democracia, enquanto que $48,84 \%$ participam apenas ocasionalmente (participa, mas não todo mês). Apenas 6,98\% dos respondentes disseram que participam frequentemente (ao menos uma vez por mês) do e-Democracia.

É curioso notar, entretanto, que essa baixa regularidade de utilização do portal eDemocracia por parte dos cidadãos não está vinculada a um descrédito dos respondentes sobre as potencialidades do portal em si. Perguntados sobre se achavam que o portal eDemocracia facilita o processo de participação política dos cidadãos, a maioria $(60,47 \%)$ dos respondentes responderam afirmativamente (Figura 27). 
Figura 27 - Avaliação do e-Democracia

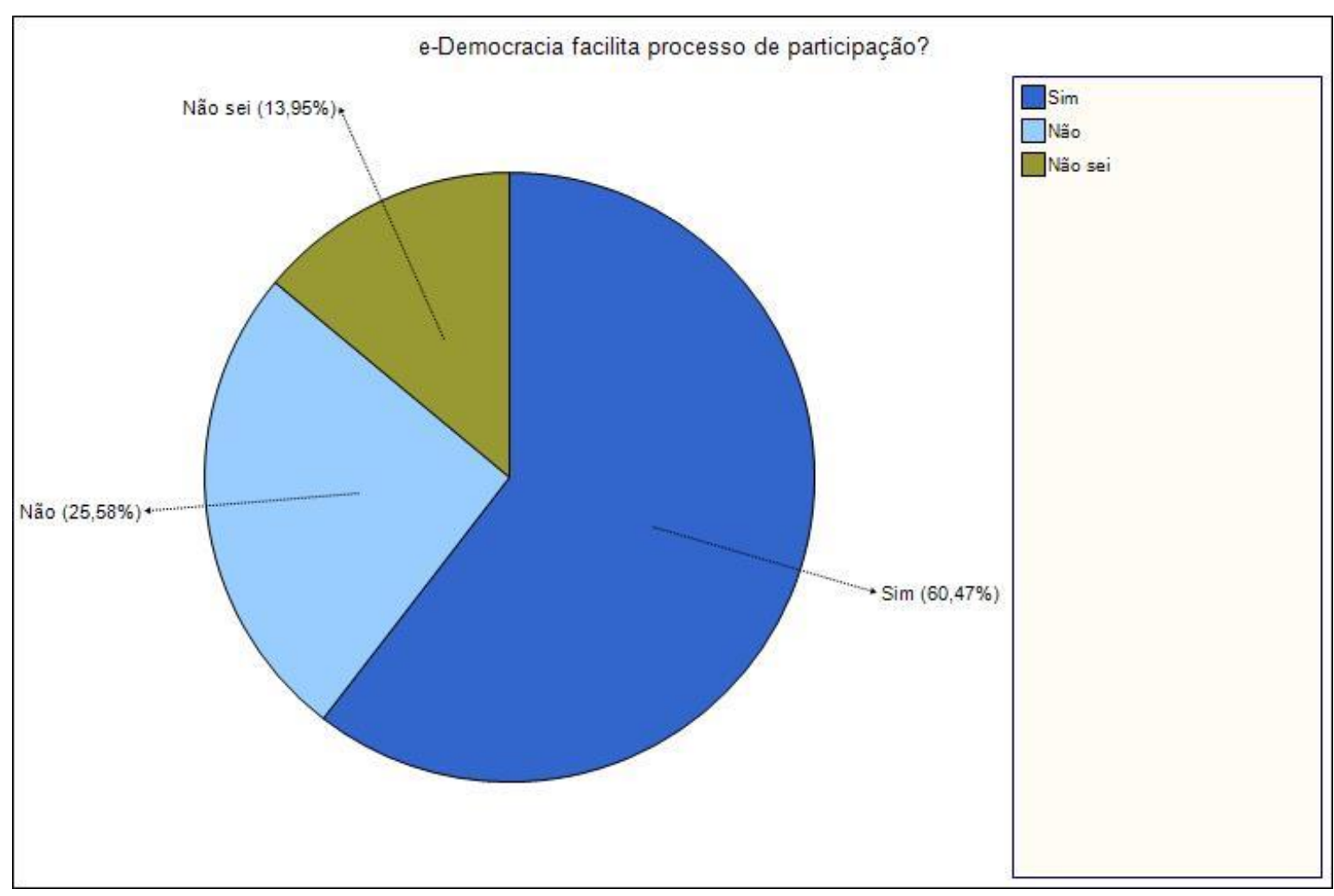

Fonte: elaboração própria.

Desta forma, o papel da tecnologia como facilitadora da interação entre Parlamento e sociedade parece ser reconhecido pelos cidadãos.

Ainda em relação aos canais de participação disponibilizados pela Câmara, foi solicitado aos cidadãos que respondessem à seguinte pergunta: "Em termos gerais, além do e-Democracia, qual o seu grau de satisfação com os demais canais de participação popular disponibilizados pela Câmara dos Deputados?”. A Figura 28 traz a consolidação das respostas. 
Figura 28 - Satisfação com demais canais de participação da Câmara

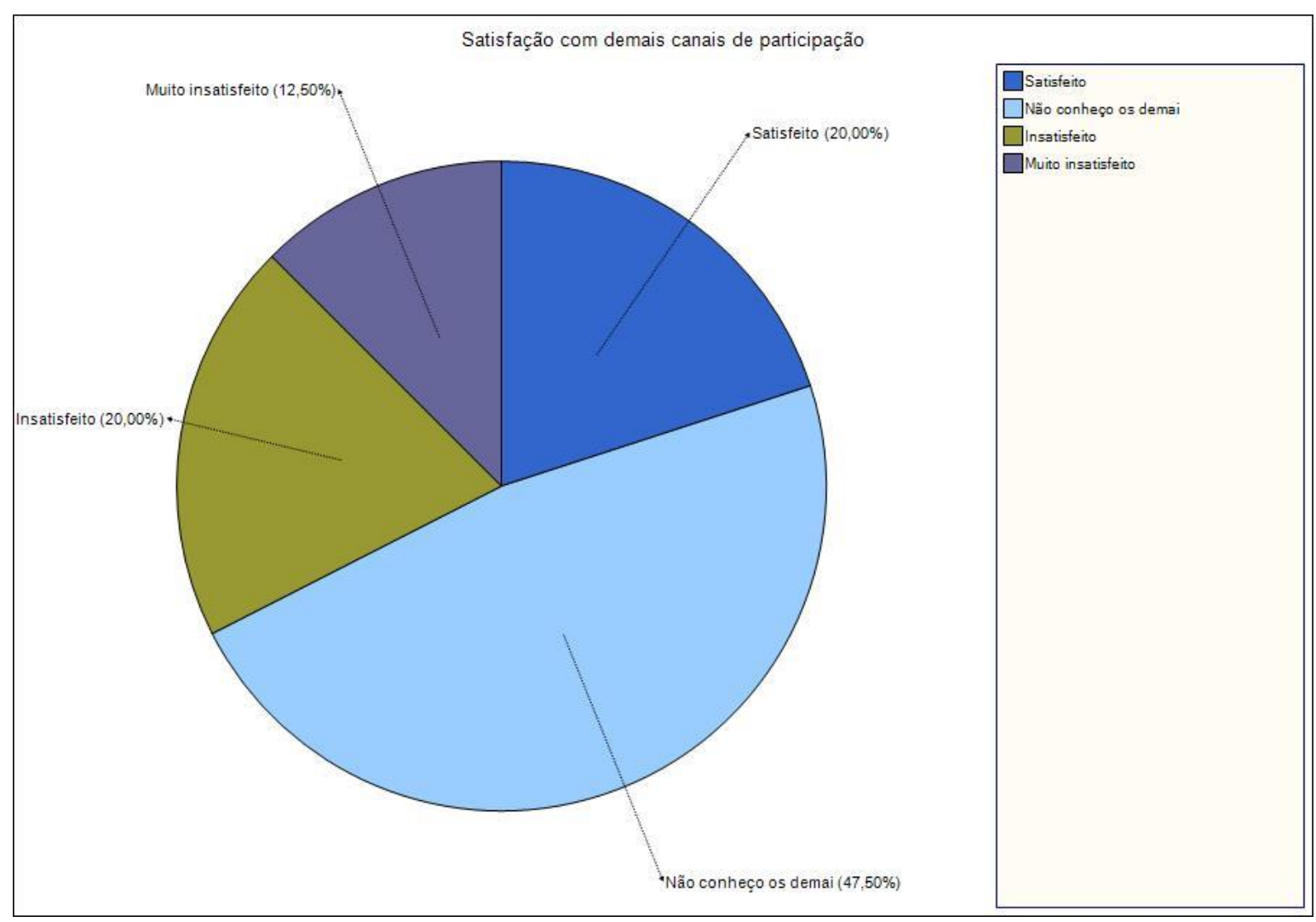

Fonte: elaboração própria.

Destacam-se dois resultados: (1) quase metade dos respondentes $(47,50 \%)$ desconhecem quais são os outros canais de participação, além do e-Democracia, instituídos e disponibilizados pela Câmara dos Deputados, e (2) o contingente de respondentes insatisfeitos e muito insatisfeitos com os outros canais soma $32,50 \%$, ficando acima da quantidade de respondentes que se declararam satisfeitos com os demais canais (20\%). Nenhum respondente afirmou estar muito satisfeito com os demais canais de participação.

Voltando ao e-Democracia, que outros fatores explicativos, além da ausência de respostas dos parlamentares às manifestações dos cidadãos, poderiam estar por trás da baixa regularidade no uso do portal e na percepção geral entre os respondentes de que sua participação não conseguiu influenciar a atuação dos deputados?

Uma insatisfação generalizada com o funcionamento da democracia brasileira pode ser um dos mecanismos gerativos para as observações empíricas. A insatisfação com a operação da democracia no Brasil fica evidenciada no gráfico da Figura 29, que resume as 
respostas à pergunta "Em termos gerais, qual o seu grau de satisfação com o funcionamento da democracia no Brasil?".

Figura 29 - Grau de satisfação com a democracia brasileira.

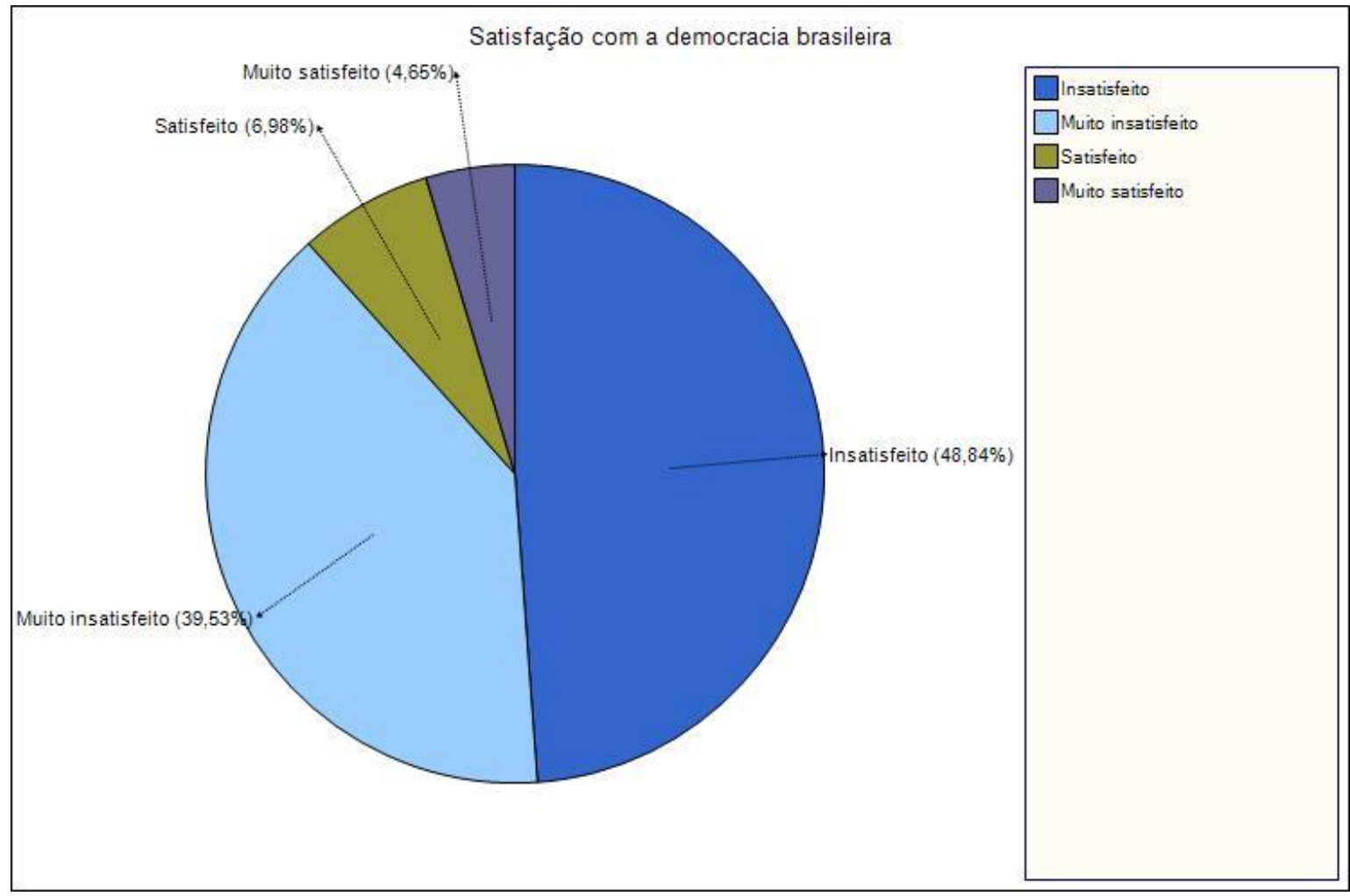

Fonte: elaboração própria.

Uma maioria extremamente expressiva $(88,37 \%)$ dos respondentes estão ou muito insatisfeitos ou insatisfeitos com o funcionamento da democracia brasileira. Apenas $11,63 \%$ dos respondentes se dizem satisfeitos ou muito satisfeitos com a democracia no Brasil. Aqui entramos na seara da formação da opinião pública. Vários atores disputam o imaginário das pessoas a cerca do mundo em geral, e sobre a esfera da política em particular, num processo constante de "conquista de mentes e corações". Numa sociedade de consumo na qual vivemos, existe todo um aparato publicitário que trabalha esse imaginário e os desejos para criar níveis de insatisfação que serão geradores da pulsão para consumir. O campo político profissional encontra na mídia de massa um aliado importante na tarefa de formação da opinião pública. Da simbiose entre mídia e política, surgem algumas distorções ou desfigurações da democracia, como propôs Nádia Urbinati (URBINATI, 2014). Urbinati identifica o que chama de mutações da democracia ou 
desfiguração da diarquia democrática composta por vontade e opinião. Para ela, a democracia representativa pode ser definida como governo por opinião (doxa), pois a chance de contestar e controlar o poder aumenta à medida que as opiniões dos cidadãos deixam de estar confinadas às suas mentes ou mantidas como opiniões privadas.

Em relação à diarquia democrática, continua Urbinati, existem três papéis desempenhados pela doxa no fórum público: (1) cognitivo ou a necessidade de informação, (2) político ou a formação e contestação da agenda e (3) estético ou um apelo à transparência e à submissão da atividade política ao público. Em relação a esses papéis, identifica uma forma de desfiguração que denomina de democracia plebiscitária ou de audiência.

A democracia da audiência, quando combinada com a sociedade e a mídia de massa, pode contribuir para a produção de uma cidadania passiva. O plebiscitarismo promete restaurar a noção de "Povo" como um conceito significativo de identidade coletiva dentro da vida política contemporânea e o faz transformando-o, em sua capacidade coletiva, em um mero "espectador das elites políticas". A audiência visual se torna a única capacidade coletiva do povo.

Na perspectiva da democracia da audiência, os procedimentos políticos estariam reservados para a elite governante, ao passo que a presença ocular, para as massas. $\mathrm{O}$ modelo da democracia da audiência seria o esquema da política de Roma, com sua mistura de patrícios que agem e plebeus que atendem, e que retira da opinião qualquer implicação política ou deliberativa. Há aqui dois modelos de democracia e de cidadania representados por duas cidades-estado - Roma, que pressupõe o cidadão-espectador e se baseia no princípio da isonomia (igualdade formal perante a lei), e Atenas, que se fundamenta no princípio da isegoria, isto é, na participação (expressão) ativa dos cidadãos - incluindo trabalhadores e pobres - nos fóruns de deliberação política.

Em outro texto, Urbinati descreve o novo plebiscitarismo da audiência em termos de um "aglomerado indistinto de indivíduos que compõe o público, um ator não coletivo que vive no espaço privado da domesticidade e, quando é agente dotado de opinião, atua como receptor ou espectador de um espetáculo encenado por técnicos da comunicação midiática e recitado por personagens políticos” (URBINATI, 2013, p. 86). Desta forma, o 
habitat natural do cidadão passivo e privatizado é a política-espetáculo, que coloca seu apreciador na condição de espectador. Com relação ao sentido cênico da políticaespetáculo, Wilson Gomes reconhece que "a política parece exigir de nós cada vez menos a condição de cidadãos ativos, convocados à mobilização ou a alguma forma de engajamento emocional e corpóreo, enquanto cada vez mais nos coloca na condição de consumidores dos produtos do show business, cidadãos-consumidores... Porque a consumimos como espectador, a política se nos parece como espetáculo" (GOMES, 2004, p. 383).

Se há espectadores, é de supor que hajam atores. Neste sentido é que se fala da política como dramaturgia, na qual políticos profissionais incorporam certos papéis, recitam falas, simulam conflitos. Existe a "política do plenário" e a "política de bastidores". A primeira é feita de discursos e simulacros. Na segunda se faz a "verdadeira" política, onde são negociados e celebrados acordos e conchavos entre partidos e lideranças políticas; o locus da responsividade de fato e da "verdadeira" prestação de contas dos representantes aos seus financiadores de campanha.

Paradoxalmente, a insatisfação generalizada com o funcionamento da democracia brasileira pode ser um grande motivador para ações e intervenções populares na esfera pública, a exemplo das manifestações de junho de 2013 no Brasil, mas pode também gerar um sentimento de impotência frente ao status quo, que conduza a uma postura de passividade distópica.

A insatisfação, porém, dá lugar à confiança quando mudamos o foco do funcionamento concreto da democracia real no Brasil para a democracia em abstrato como melhor sistema de governo. Foi solicitado aos respondentes falar quanto concordava com a seguinte sentença: "A democracia pode ter problemas, mas é o melhor sistema de governo". As respostas estão consolidadas no gráfico da Figura 30. 
Figura 30 - Democracia como melhor sistema de governo

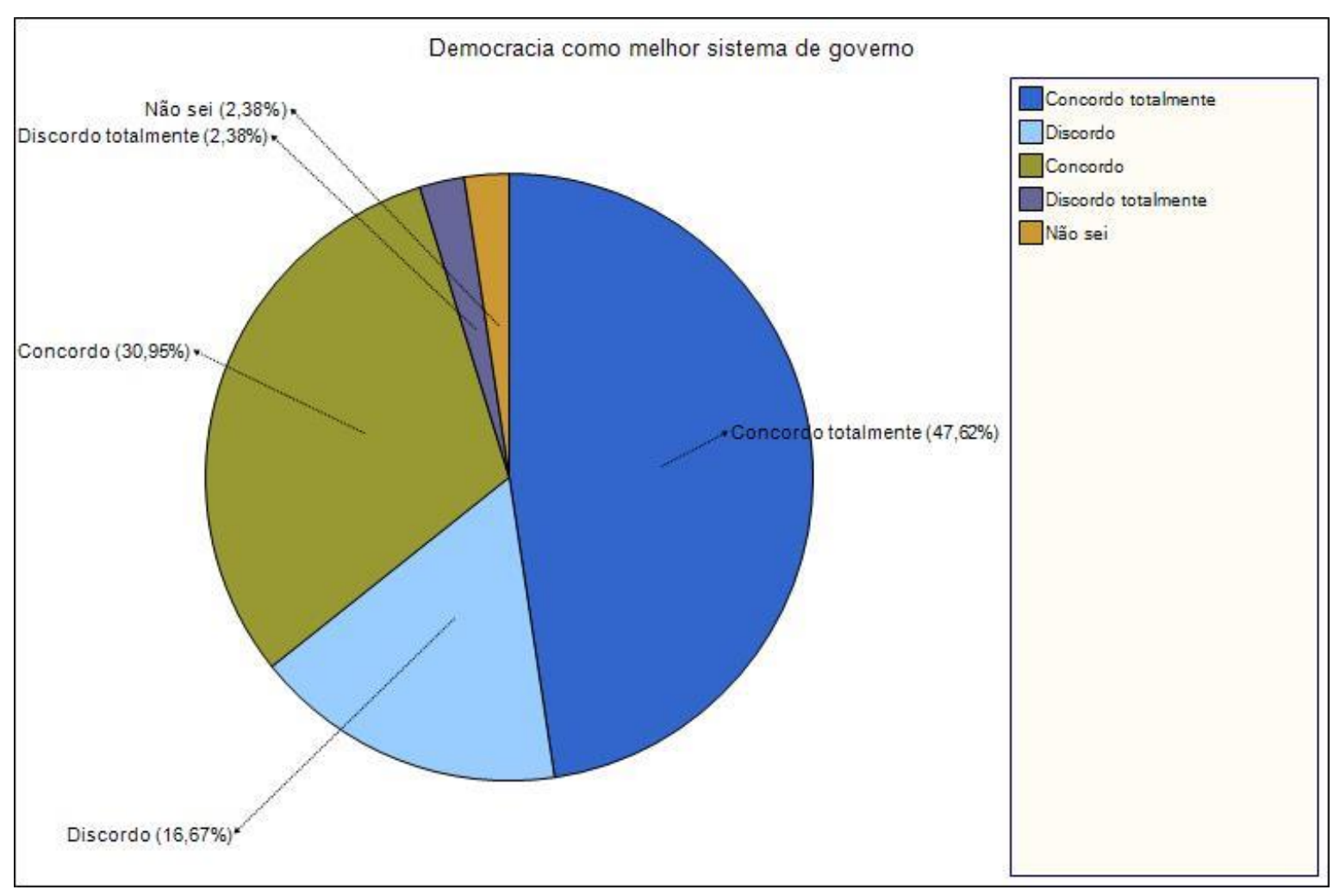

Fonte: elaboração própria.

Somando-se os respondentes que disseram concordar totalmente $(47,62 \%)$ com a proposição de que democracia é como melhor sistema de governo, aos que responderam que concordam, chega-se à maioria de 78,57\% do total de respondentes. Os que não acham que a democracia seja o melhor sistema de governo, somam 19,05\%. A partir desses resultados pode-se inferir que a insatisfação e críticas dos cidadãos não estariam direcionadas ao regime democrático per si, nem às instituições da democracia representativa, mas à sua atual implementação no sistema político brasileiro.

Um dado peculiar são os partidos políticos. Embora parte fundamental das instituições da democracia representativa, a legitimidade dos partidos como entidade de mediação entre sociedade e representantes eleitos vem sendo questionada recorrentemente em algumas democracias ocidentais. No Brasil, esta tendência fica evidente nos protestos de junho de 2013 e nas manifestações de rua ocorridas em 2015, marcadas por diversas expressões antipartidárias, a ponto do então secretário-geral da Presidência da República, ministro Gilberto Carvalho, manifestar, em 21/06/2013, sua preocupação com as reações 
contrárias à participação de partidos políticos nas manifestações que estavam ocorrendo no país (AGÊNCIA BRASIL, 2013).

As relações entre a autopercepção dos respondentes sobre a eficácia de sua participação e outras dimensões do questionário ficam mais aparentes a partir da análise gráfica de suas variações combinadas. Inicialmente, a Figura 31 apresenta a relação entre a autopercepção sobre a eficácia da participação e a satisfação com o funcionamento da democracia brasileira.

Figura 31 - Satisfação com democracia brasileira e autopercepção da eficácia da participação

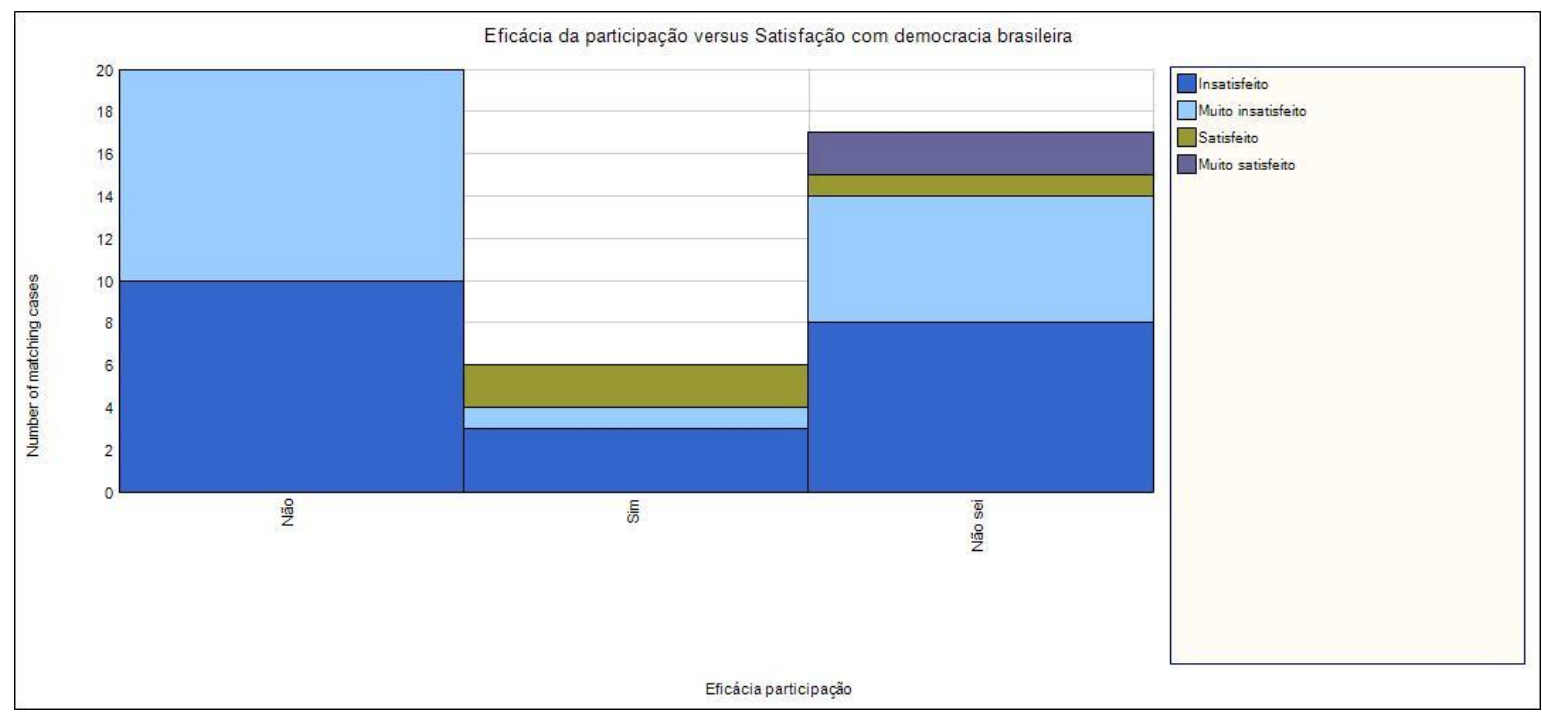

Fonte: elaboração própria.

Claramente, o grupo de respondentes com maior contingente de cidadãos muito insatisfeitos ou insatisfeitos com o funcionamento da democracia brasileira, é também o grupo que acha que sua participação no portal e-Democracia não serviu para influenciar a atuação de nenhum deputado. Inversamente, o grupo que tem o maior número de pessoas satisfeitas com a democracia brasileira corresponde ao grupo de pessoas que consideram que sua participação no e-Democracia serviu para influenciar a atuação de pelo menos um deputado. Há, portanto, uma correlação entre as duas percepções. Como a pergunta sobre a eficácia da participação foi específica sobre as manifestações dos respondentes no portal eDemocracia, não é razoável inferir do resultado da análise cruzada que um sentimento geral de insatisfação com o funcionamento da democracia brasileira possa explicar a 
percepção de ineficácia da participação no e-Democracia. Entretanto, é razoável argumentar que a experiência negativa do cidadão ao tentar influenciar o processo político através do e-Democracia contribua para reforçar a insatisfação com o funcionamento da democracia no Brasil, sendo esse, portanto, o sentido de uma relação de causa-efeito.

Com relação ao efeito da percepção da eficácia da participação sobre a regularidade do uso do portal e-Democracia, a Figura 32 mostra que o grupo de respondentes que qualificou sua participação como ineficaz é composto somente por pessoas que raramente ou apenas ocasionalmente utilizam o portal e-Democracia. O grupo de pessoas que consideram eficaz sua participação no e-Democracia possui o menor número de pessoas que raramente ou apenas ocasionalmente utilizam este canal. Isso indica que a percepção da eficácia da participação influencia o padrão de utilização do canal e-Democracia. Cidadãos que percebem que sua participação não influenciou o comportamento dos parlamentares tendem a recorrer menos ao portal e-Democracia.

Figura 32 - Autopercepção da eficácia da participação e regularidade de uso do eDemocracia

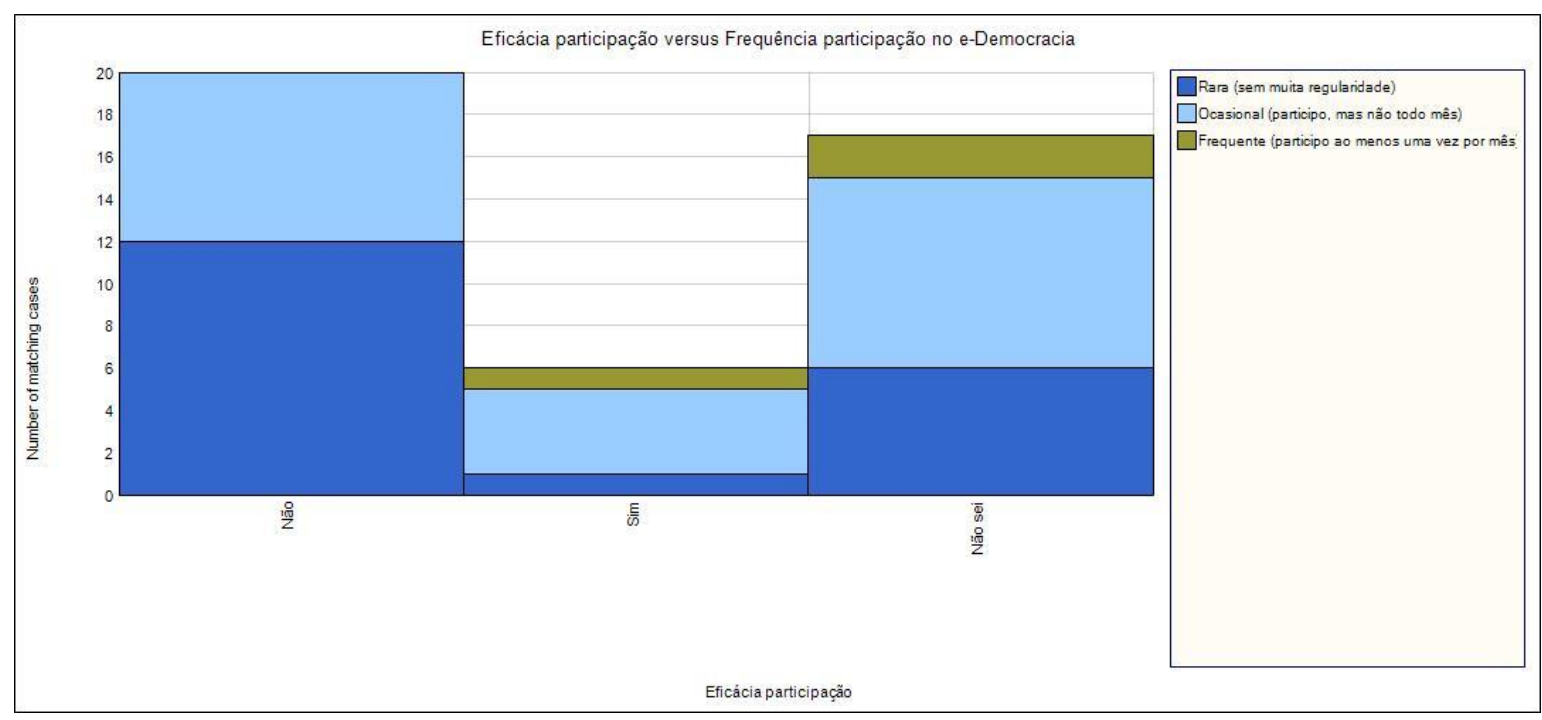

Fonte: elaboração própria.

A autopercepção da eficácia da participação também é afetada pelo fato do cidadão ter recebido ou não alguma resposta da Câmara dos Deputados sobre sua contribuição ou manifestação no portal e-Democracia. Quem recebeu alguma resposta, tende a perceber sua participação como eficaz, e vice-versa (Figura 33). 
Figura 33 - Resposta da Câmara e autopercepção da eficácia da participação

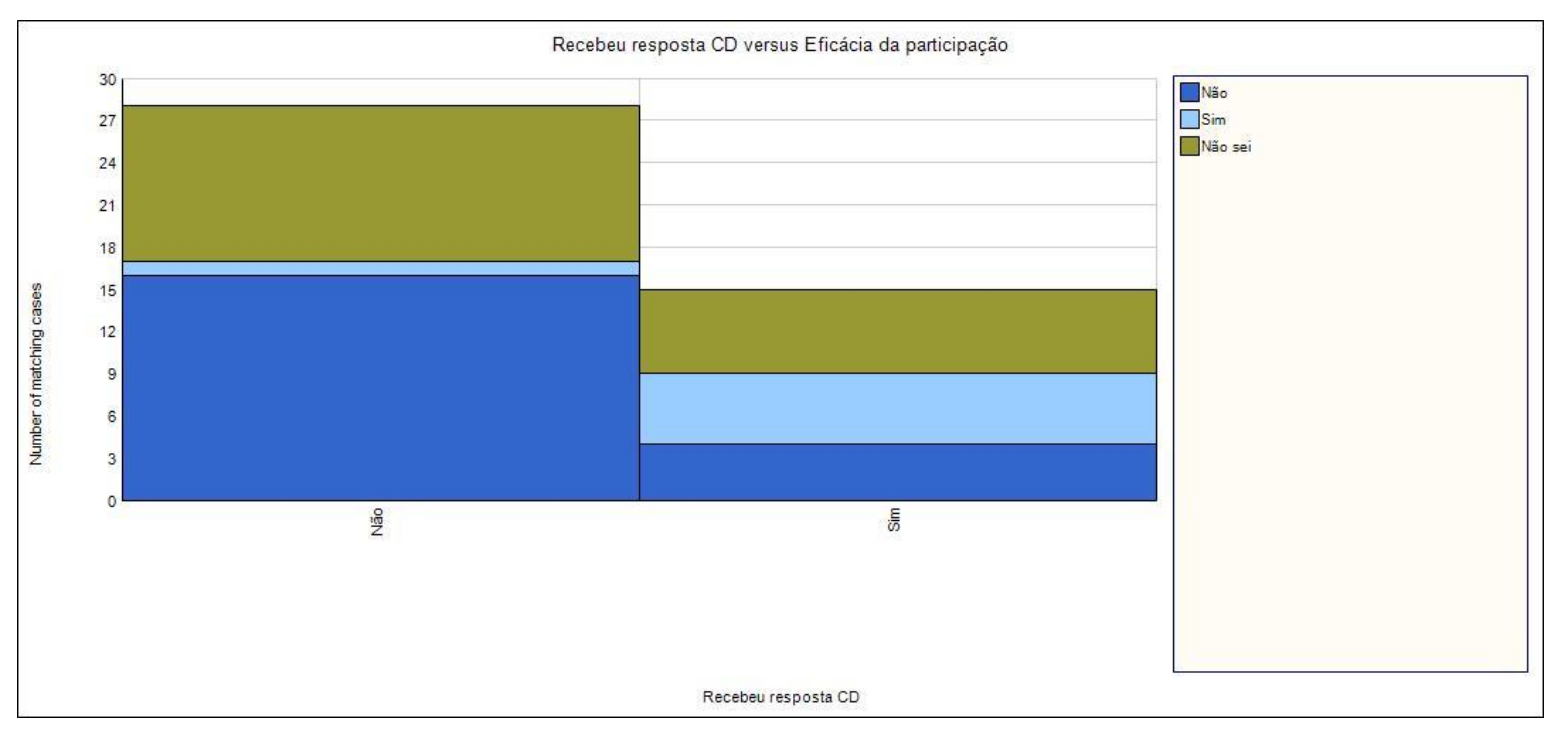

Fonte: elaboração própria.

O grupo que recebeu alguma resposta da Câmara dos Deputados às suas manifestações no portal e-Democracia também é o grupo com maior número de pessoas que qualificam sua participação como eficaz.

O fato de receber ou não algum retorno da Câmara para suas manifestações no eDemocracia também parece influenciar o padrão de regularidade de utilização do canal digital. É o que mostra o gráfico da Figura 34. O grupo que não recebeu nenhuma resposta da Câmara às suas manifestações no e-Democracia também é o grupo com maior número de pessoas que raramente ou apenas ocasionalmente utilizam o e-Democracia. Este resultado parece contradizer a aposta no poder educativo da participação, no sentido de que se aprende a participar participando (PATEMAN, 1992). Uma experiência negativa na tentativa de participação pelo canal e-Democracia desmotiva os cidadãos a continuar se esforçando em participar do processo político, produzindo um padrão de utilização ocasional ou rara dos canais de participação disponíveis. Assim, a falta de retorno às manifestações funciona como uma escola de descidadania, induzindo um postura passiva nos cidadãos. 
Figura 34 - Resposta da Câmara e regularidade de uso do e-Democracia

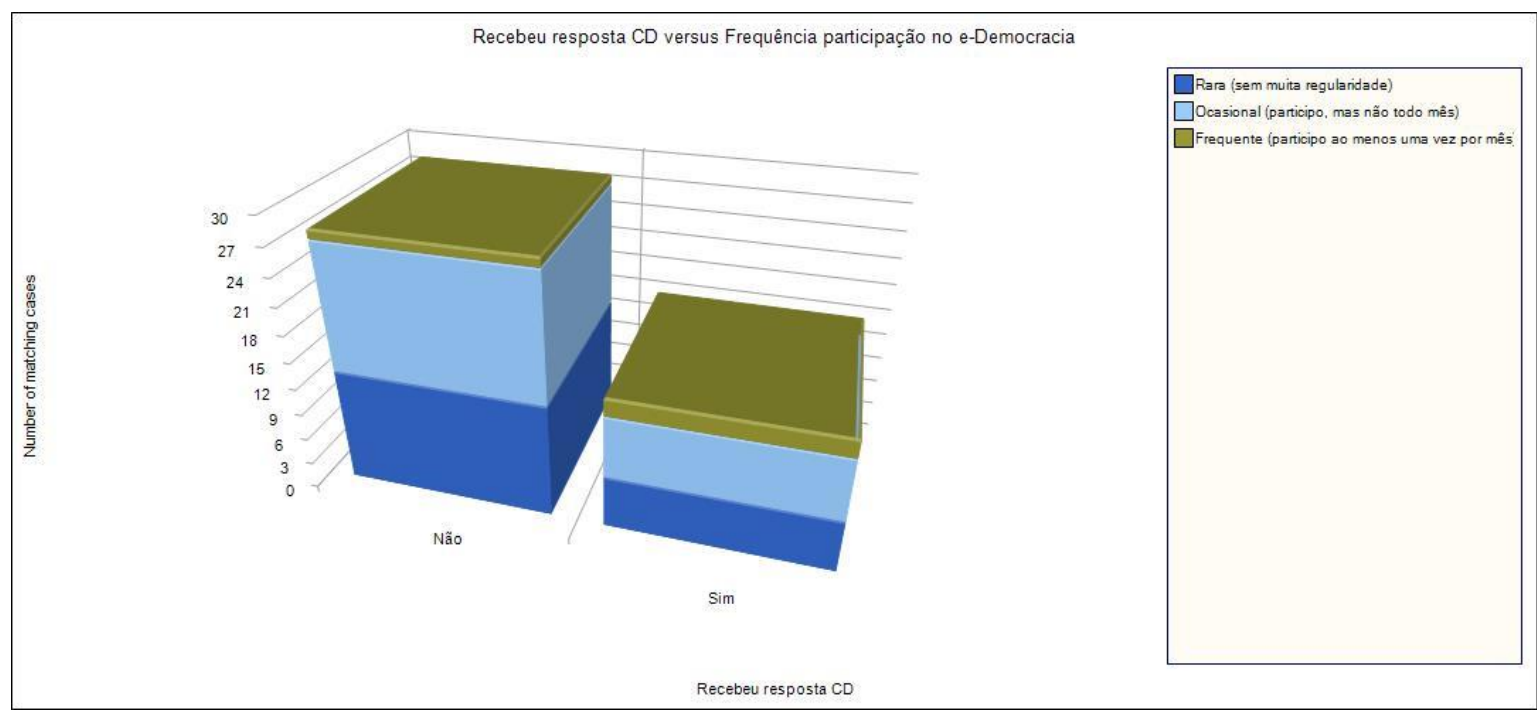

Fonte: elaboração própria.

Em geral, a maioria dos participantes estão muito insatisfeitos ou insatisfeitos com o funcionamento da democracia brasileira. Apesar desse resultado, a maioria também concorda totalmente ou simplesmente concorda que a democracia é o melhor regime de governo (Figura 35).

Figura 35 - Democracia como melhor sistema e satisfação com democracia brasileira

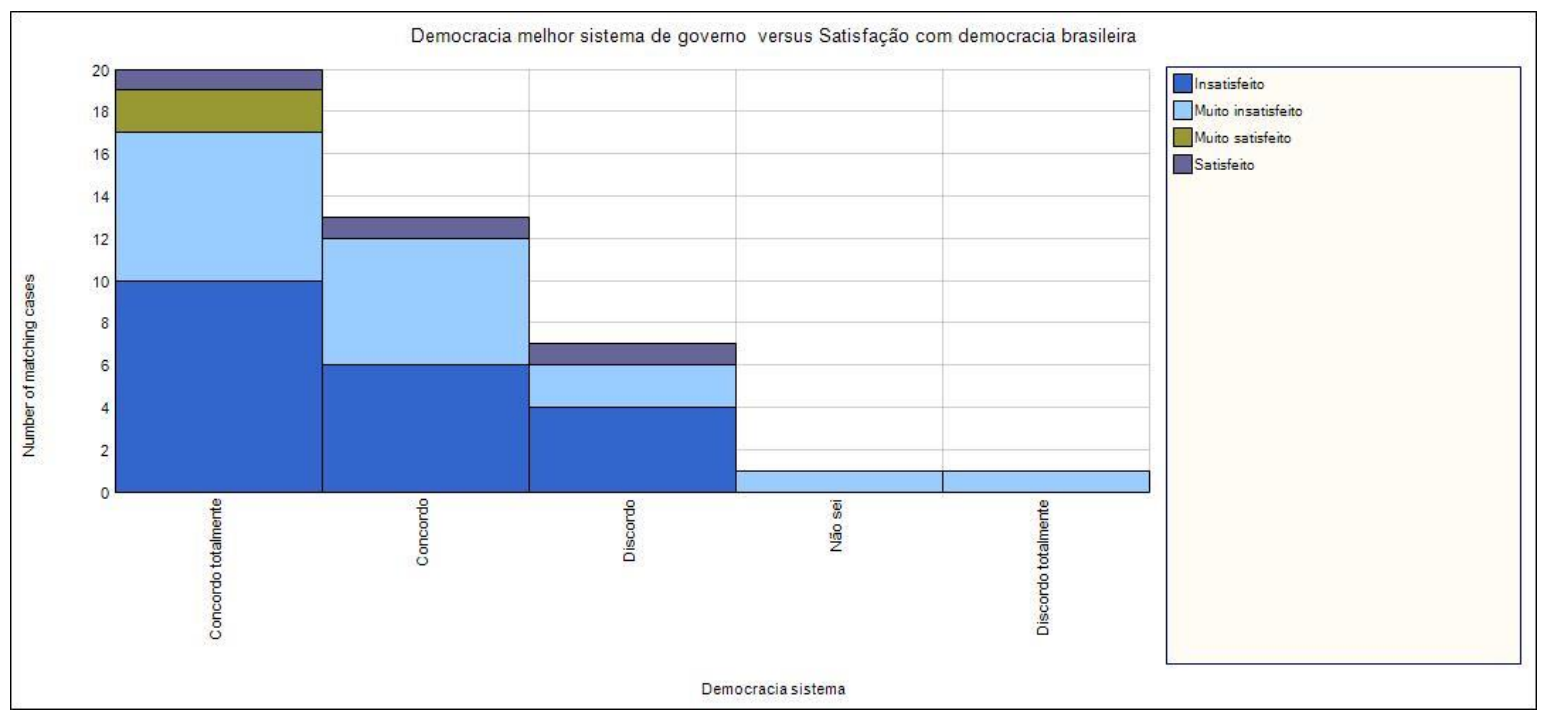

Fonte: elaboração própria. 
Esse resultado indica que os cidadãos fazem separação entre a democracia enquanto modelo de sistema de governo e a implementação particular da democracia no Brasil, avaliando-as de maneiras distintas.

O cruzamento entre escolaridade e percepção da eficácia da participação revela que quanto maior o nível de escolaridade, maior a tendência a perceber que a participação contribuiu para influenciar o comportamento dos parlamentares (Figura 36). Os únicos grupos de participantes com cidadãos que percebem que sua participação influenciou a atuação dos deputados são compostos por pessoas com nível superior completo ou pósgraduação completa.

Figura 36 - Escolaridade e percepção da eficácia da participação

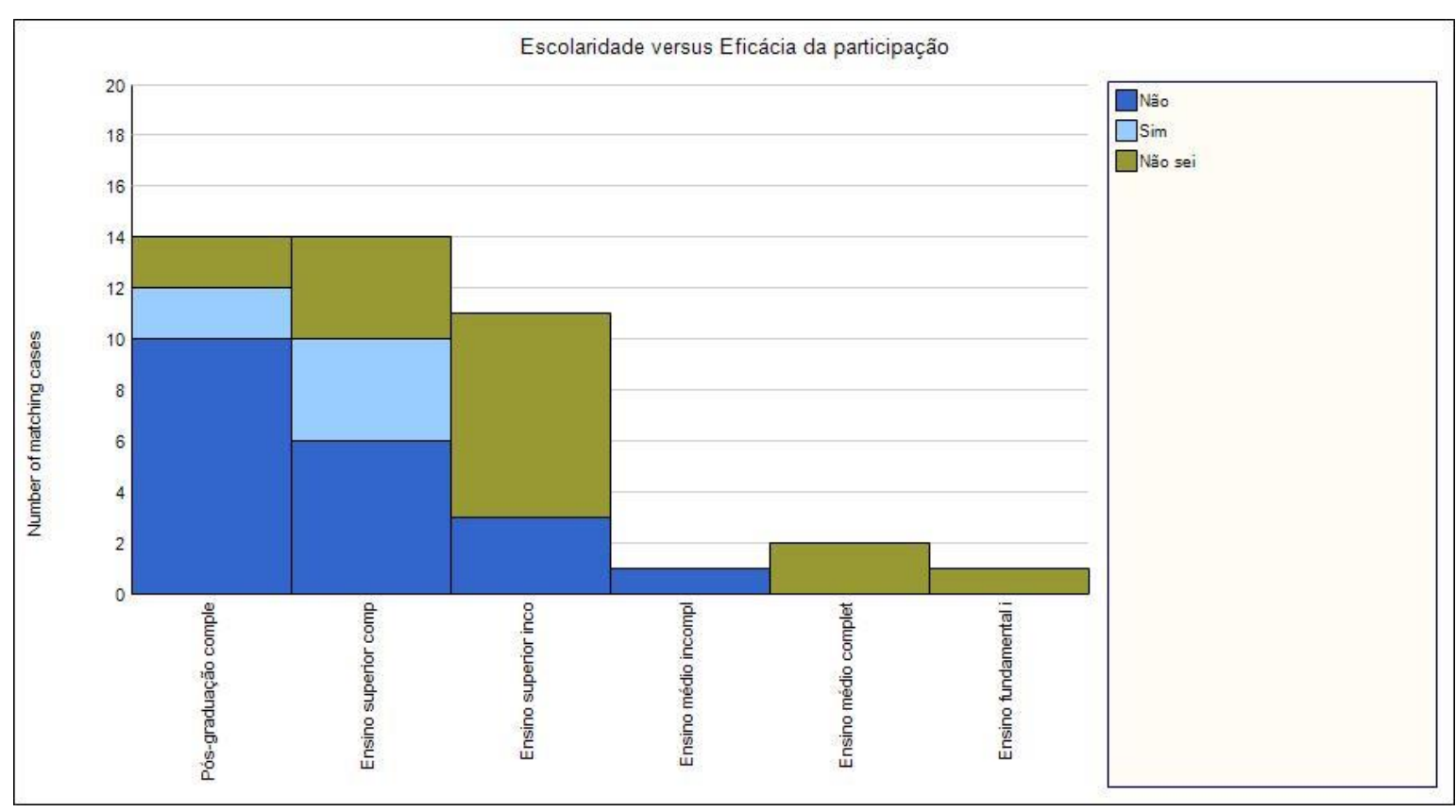

Fonte: elaboração própria.

Ainda assim, é alto o percentual de participantes com pós-graduação completa que percebem que sua participação não conseguiu influenciar o comportamento dos deputados, chegando a 70\%, como mostra o gráfico da Figura 37. Para os participantes com nível superior completo, este valor é de $40 \%$. 
Figura 37 - Escolaridade e percepção da eficácia da participação (percentuais)

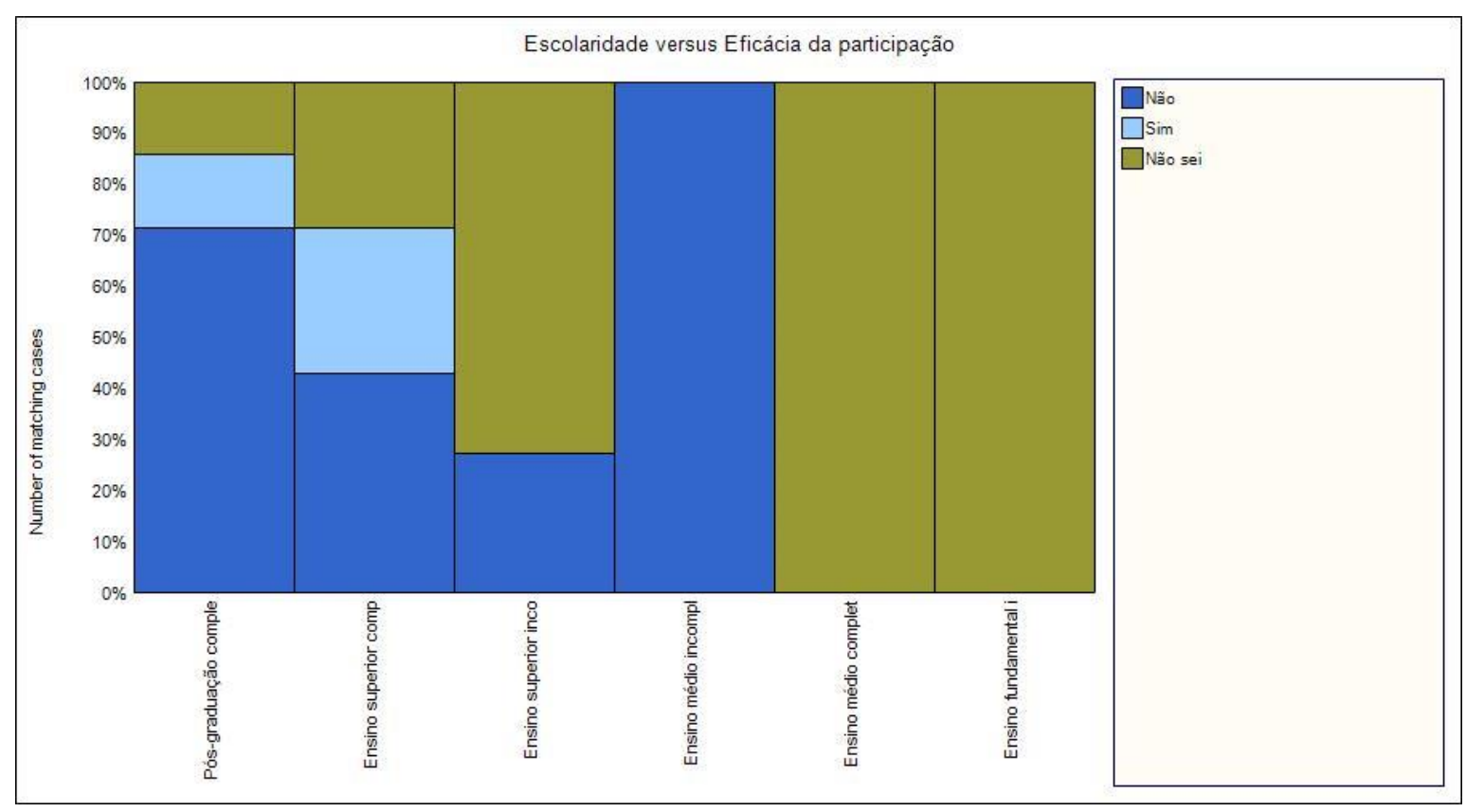

Fonte: elaboração própria.

Portanto, não foi possível identificar um padrão de correlação entre escolaridade e a percepção sobre a eficácia da participação.

Outro exercício de análise cruzada foi verificar se haveria alguma correlação entre o fato de fazer parte de algum movimento social, ONG ou partido político e as dimensões da percepção da eficácia da participação e do participante receber ou não algum retorno da Câmara dos Deputados às suas manifestações. Os resultados são apresentados nos gráficos da Figura 38.

Figura 38 - Relação do pertencimento a entidades e outras dimensões

(a) 


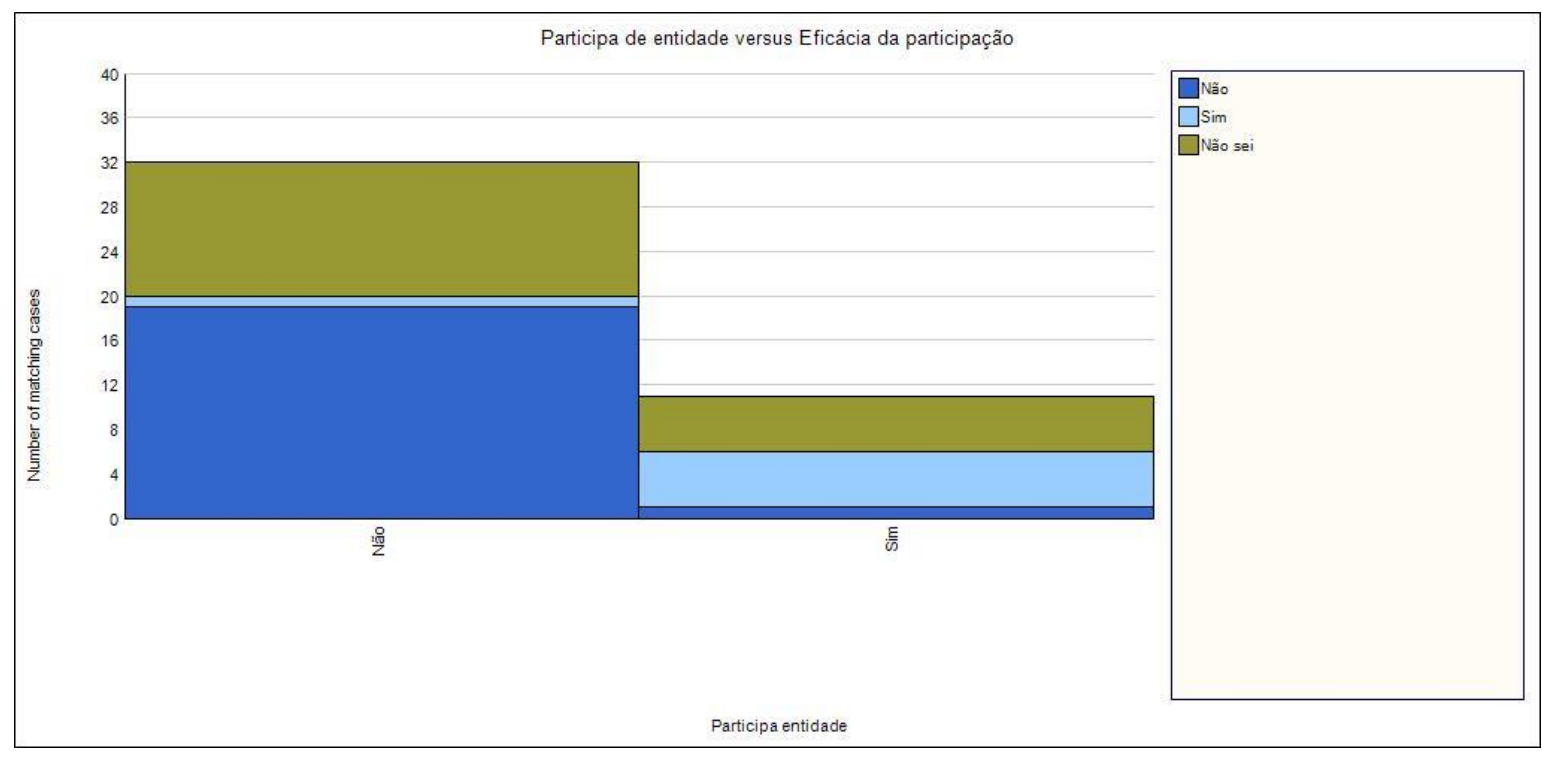

(b)

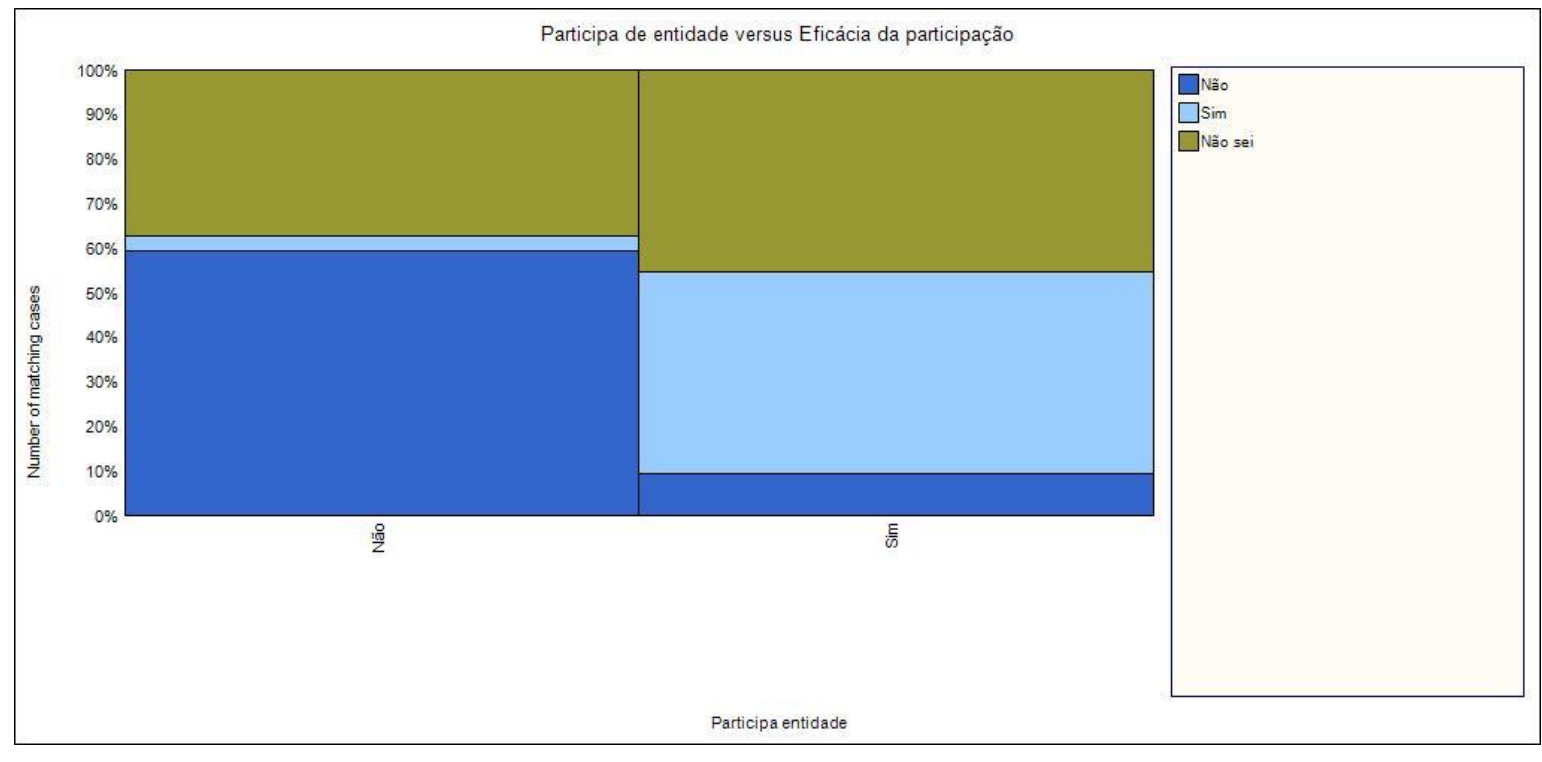

(c) 


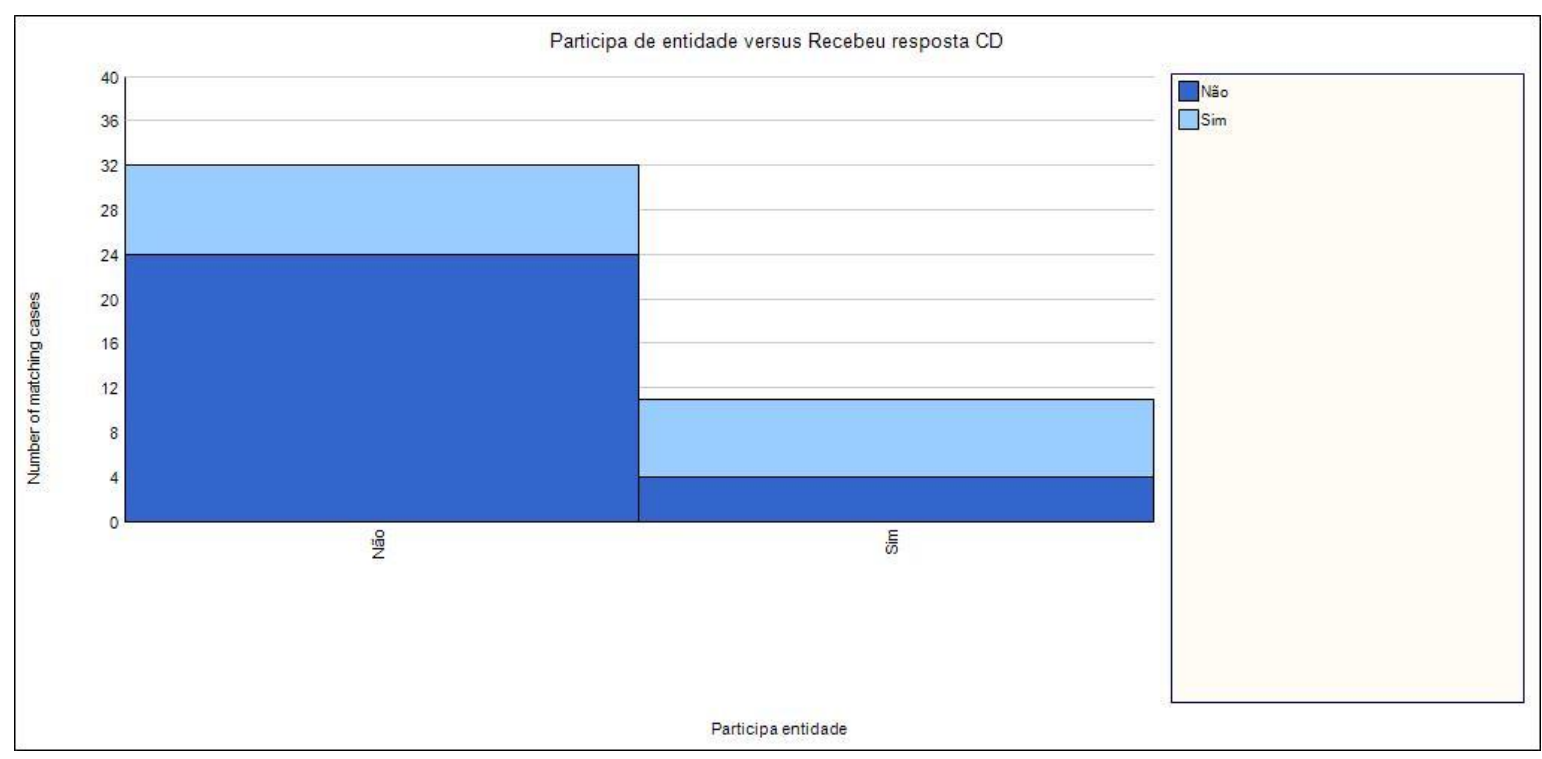

(d)

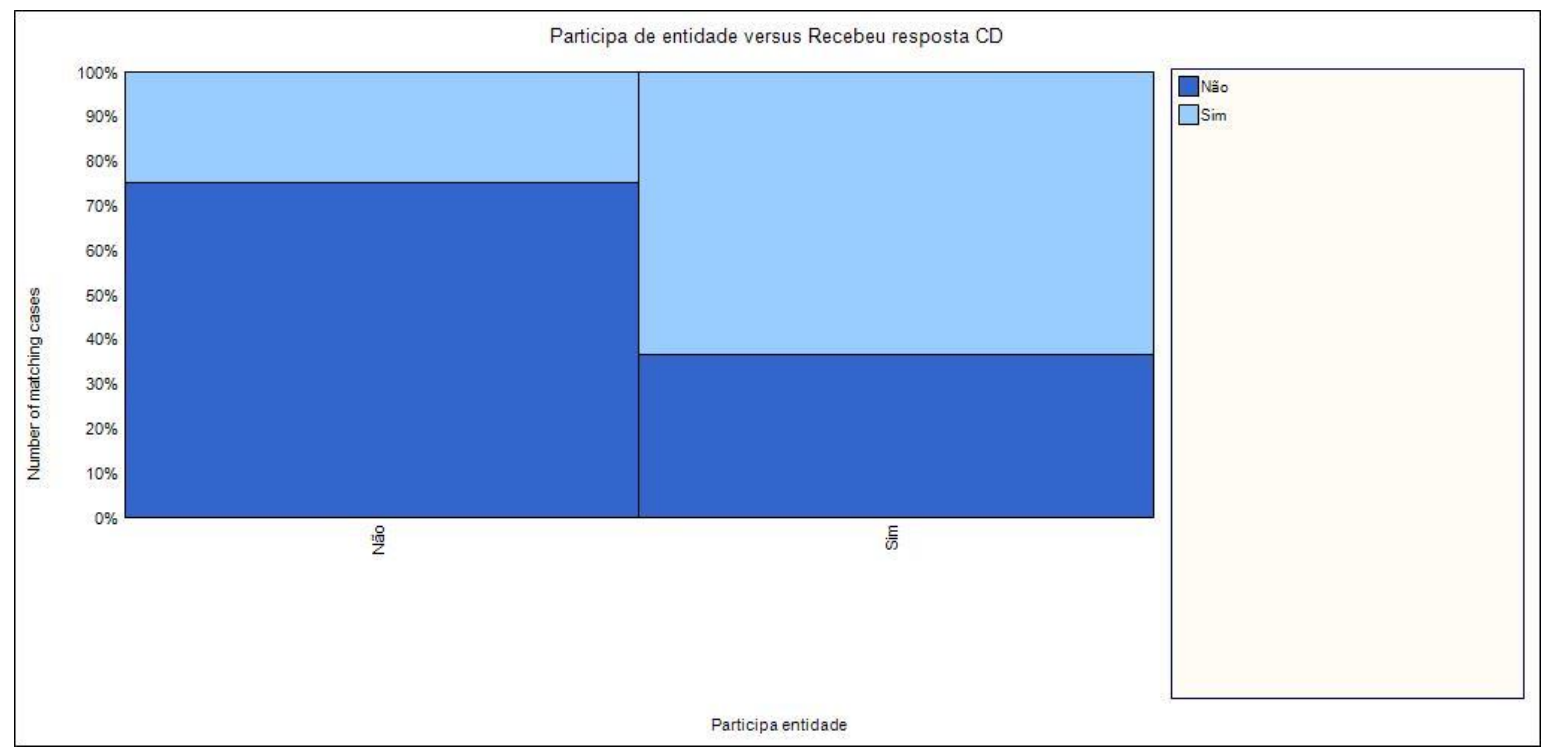

Fonte: elaboração própria.

Da Figura 38(a), o grupo com maior número de respondentes que percebem sua participação como eficaz é também o grupo composto por pessoas que fazem parte de alguma entidade da sociedade civil organizada. Este grupo também possui o menor número de pessoas que consideram que sua participação não serviu para influenciar o comportamento dos parlamentares, sendo percebida, portanto como ineficaz. Pela Figura 
38(b), este número corresponde a apenas $10 \%$ dos respondentes que fazem parte de alguma entidade, enquanto que os respondentes deste grupo que percebem sua participação como eficaz corresponde a aproximadamente $50 \%$.

Um maior poder de articulação e de lobby das entidades da sociedade civil com o corpo político da Câmara dos Deputados, quando comparado com os cidadãos que não participam dessas entidades, pode ser uma explicação para os resultados apresentados pelos gráficos das Figuras 38(a) e (b). A análise cruzada entre pertencer a alguma entidade e receber ou não resposta da Câmara às suas manifestações pelo e-Democracia parece confirmar esse entendimento - Figuras 38(c) e (d). Enquanto o número de pessoas que receberam alguma resposta da Câmara às suas manifestações é o mesmo para os grupos de pessoas que pertencem e não pertencem a entidades como ONGs, movimentos sociais e partidos políticos, o número de pessoas que não receberam retorno às suas manifestações é muito maior no segundo grupo, aqueles que não pertencem a entidades como ONGs, movimentos sociais e partidos políticos (Figura 38(c)).

A partir da Figura 38(d), o percentual de pessoas que receberam algum tipo de resposta da Câmara dos Deputados para grupo de respondentes que participam de alguma entidade é de aproximadamente $60 \%$, enquanto que para o grupo dos respondentes que não participam de nenhuma entidade, esse valor cai para $25 \%$. Então, conclui-se que as pessoas que fazem parte de alguma entidade como ONGs, movimentos sociais e partidos políticos, tendem a receber alguma resposta da Câmara dos Deputados às suas manifestações pelo eDemocracia e a perceber que sua participação foi eficaz (conseguiu influenciar as atitudes dos deputados).

A imagem ou legitimidade do canal e-Democracia perante os respondentes parece ser influenciada pelo fato do cidadão ter recebido ou não alguma resposta da Câmara dos Deputados às suas manifestações. É o que fica evidente pelos gráficos da Figura 39. O grupo de respondentes com maior contingente de pessoas que responderam que o eDemocracia não facilita a participação também é o grupo dos que não receberam nenhuma resposta da Câmara dos Deputados às suas manifestações no e-Democracia (Figura 39(a)). 
Figura 39 - Relação entre receber resposta da Câmara e imagem do e-Democracia perante participantes

(a)

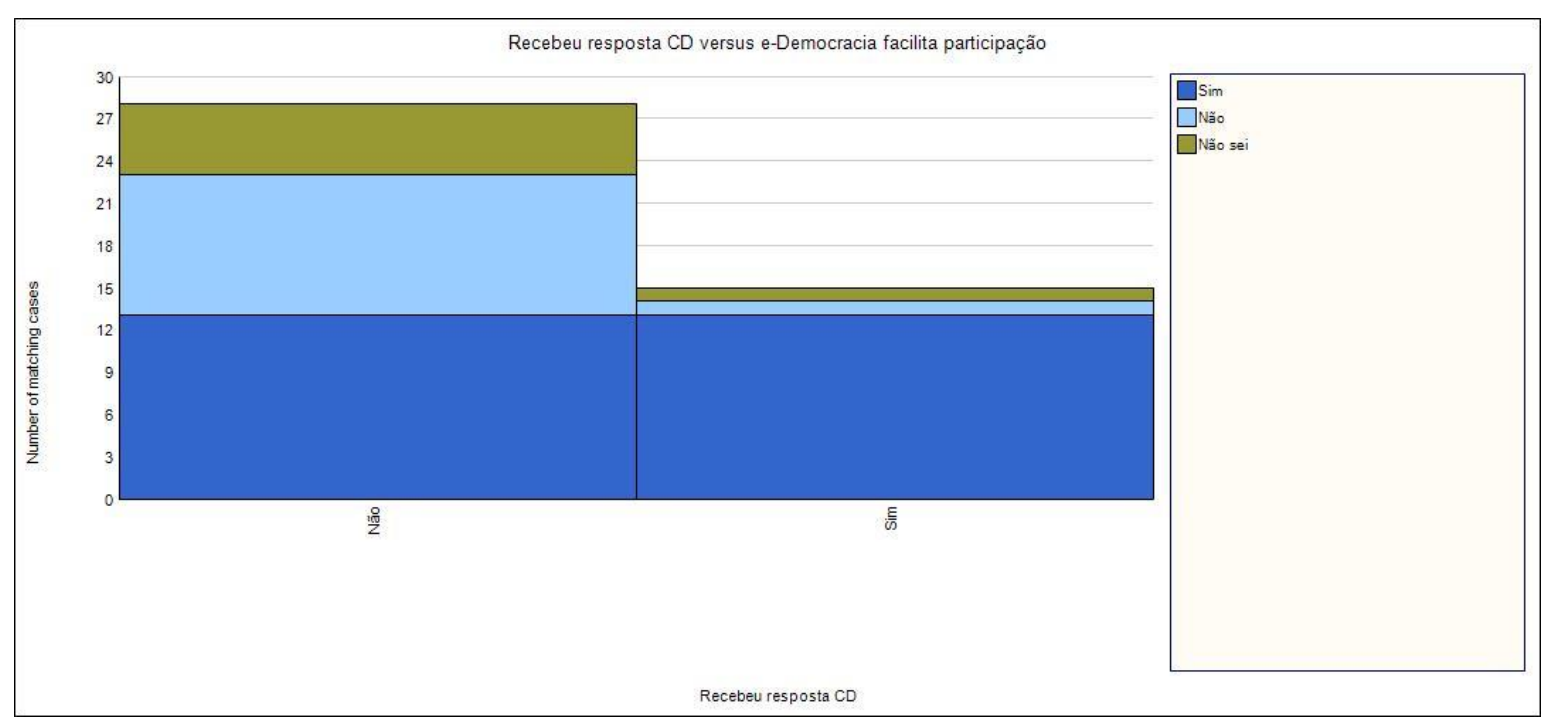

(b)

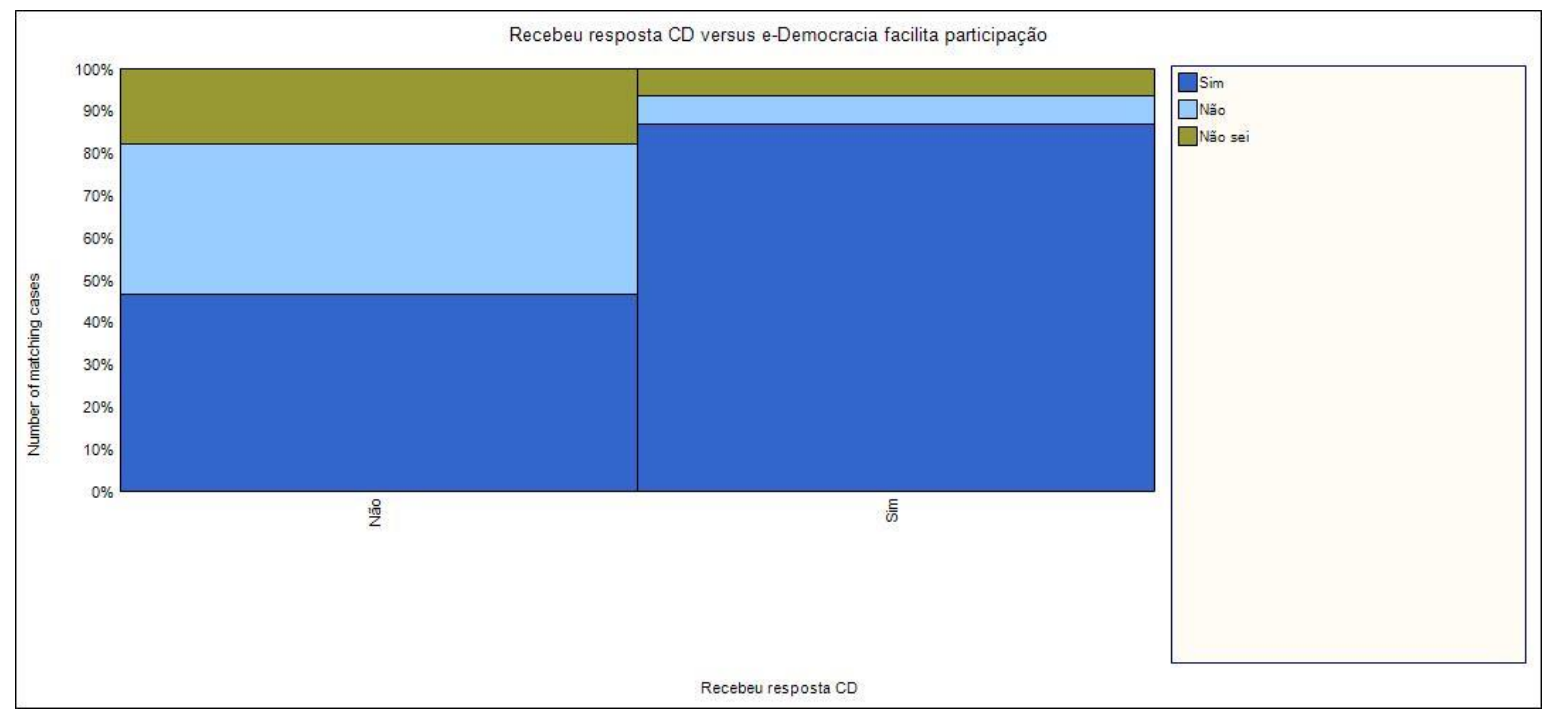

Fonte: elaboração própria.

E de acordo com o gráfico da Figura 39(b), o percentual de pessoas entre os respondentes que afirmaram que o e-Democracia não facilita a participação ou tem dúvidas quanto a isso somam cerca de $55 \%$ para o grupo de pessoas que não receberam nenhuma resposta da Câmara às suas manifestações, enquanto que para o grupo de pessoas que 
relatou ter recebido alguma resposta da Câmara, o percentual cai para aproximadamente $15 \%$. Desta forma, parece que o fato de não receber resposta da Câmara às manifestações realizadas no e-Democracia contribui para deslegitimar o e-Democracia enquanto instituição participativa perante os cidadãos.

O cruzamento dos dados para a percepção sobre a eficácia da participação no eDemocracia e a satisfação com os demais canais de participação na Câmara dos Deputados revela que a quantidade de respondentes satisfeitos com os demais canais é a mesma para o grupo que consideram eficaz sua participação e para o que percebe como ineficaz a sua participação (Figura 40). Contudo, o contingente de pessoas que estão insatisfeitos com os demais canais ou que declararam desconhecê-los é significativamente maior para o grupo que considera sua participação ineficaz, isto é, que não serviu para influenciar o comportamento dos parlamentares. O número de pessoas muito insatisfeitas é o mesmo para os dois grupos, sendo de apenas 1 pessoa.

Figura 40 - Relação entre percepção da eficácia da participação e satisfação com os demais canais de participação

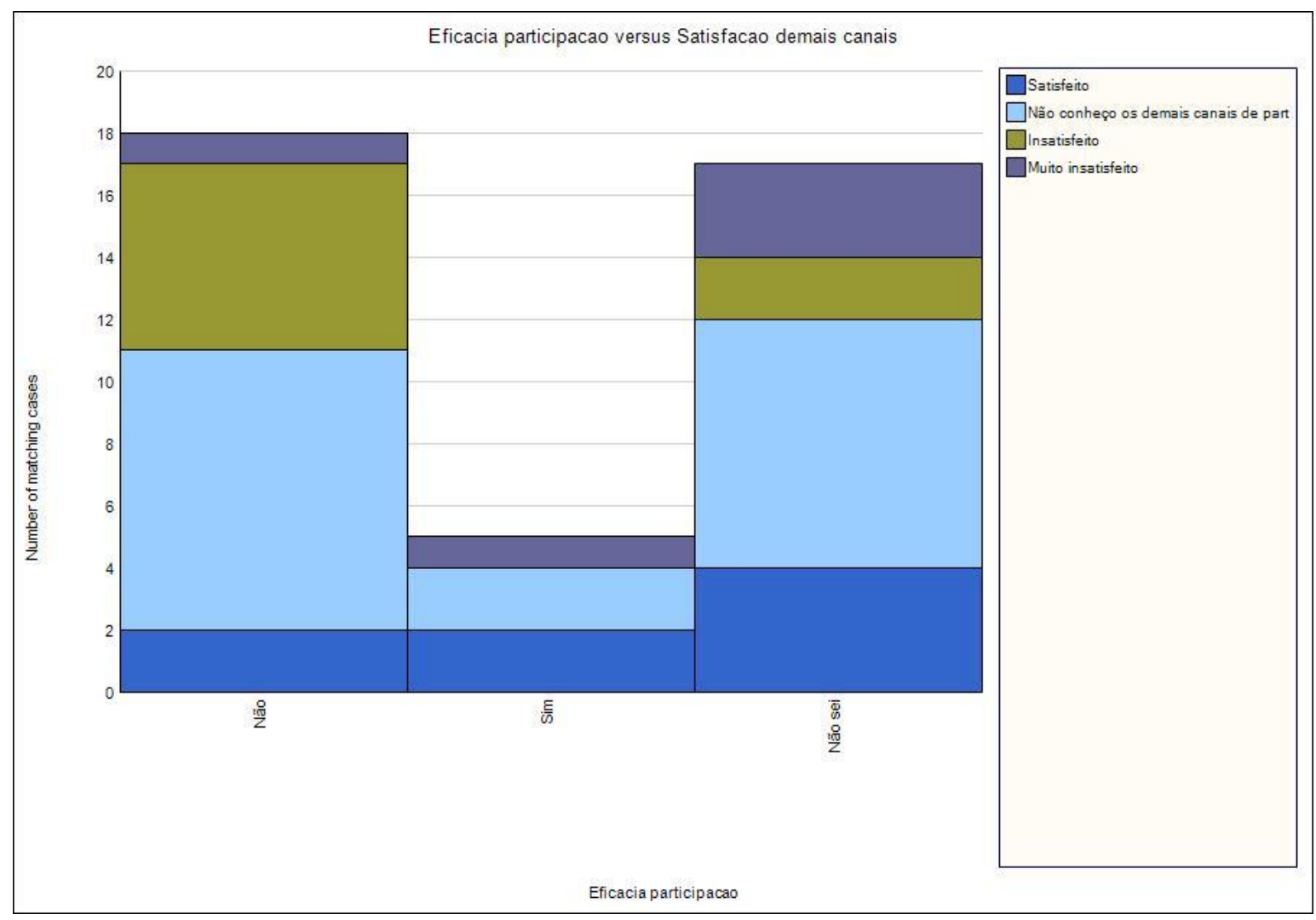

Fonte: elaboração própria. 
Em termos percentuais (Figura 41), enquanto o contingente de pessoas insatisfeitas com os demais canais é $0 \%$ no grupo de respondentes que consideram sua participação eficaz, para o grupo que percebe sua participação como ineficaz o percentual chega a aproximadamente 33\%. Com relação ao percentual de respondentes que declararam desconhecer os demais canais de participação da Câmara, não há diferença significativa para os dois grupos, que apresentam valores de $50 \%$ e $40 \%$. Assim, parece não haver correlação entre percepção da eficácia da participação e desconhecimento dos demais canais de participação. É possível que o desconhecimento esteja relacionado a deficiências na divulgação desses canais pela Câmara dos Deputados.

Portanto, é possível inferir desses resultados que os cidadãos que consideram que sua participação no e-Democracia não foi eficaz, não contribuindo para influenciar a atuação dos deputados, tendem a estar insatisfeitos com os demais canais de participação disponibilizados pela Câmara dos Deputados.

Figura 41 - Relação entre percepção da eficácia da participação e satisfação com os demais canais de participação (percentuais)

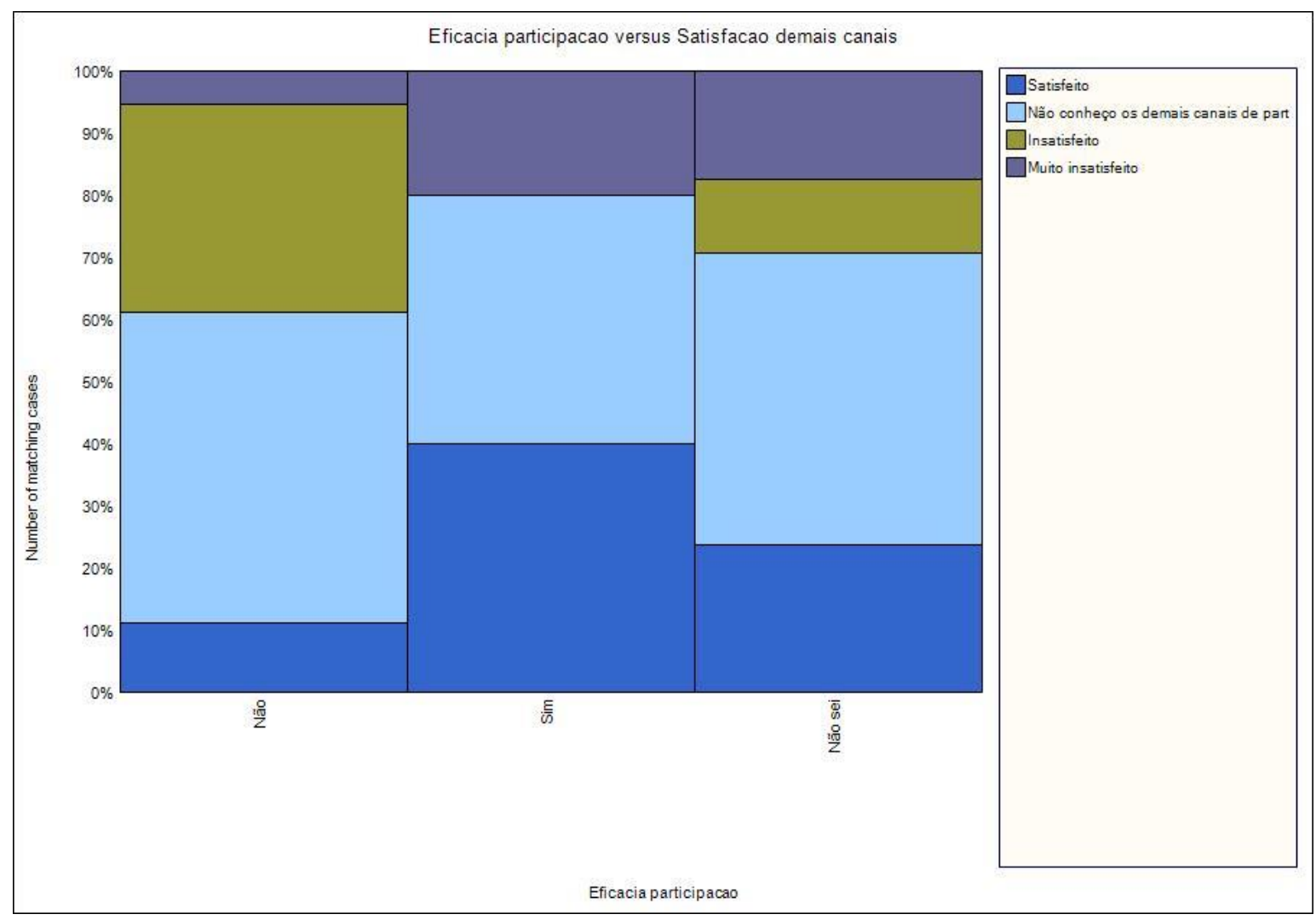

Fonte: elaboração própria. 
Outro aspecto importante é investigar possíveis correlações entre o fato de receber ou não resposta da Câmara às manifestações no e-Democracia e a satisfação com os demais canais de participação popular (Figura 42).

Figura 42 - Relação entre resposta da Câmara às manifestações e satisfação com os demais canais de participação

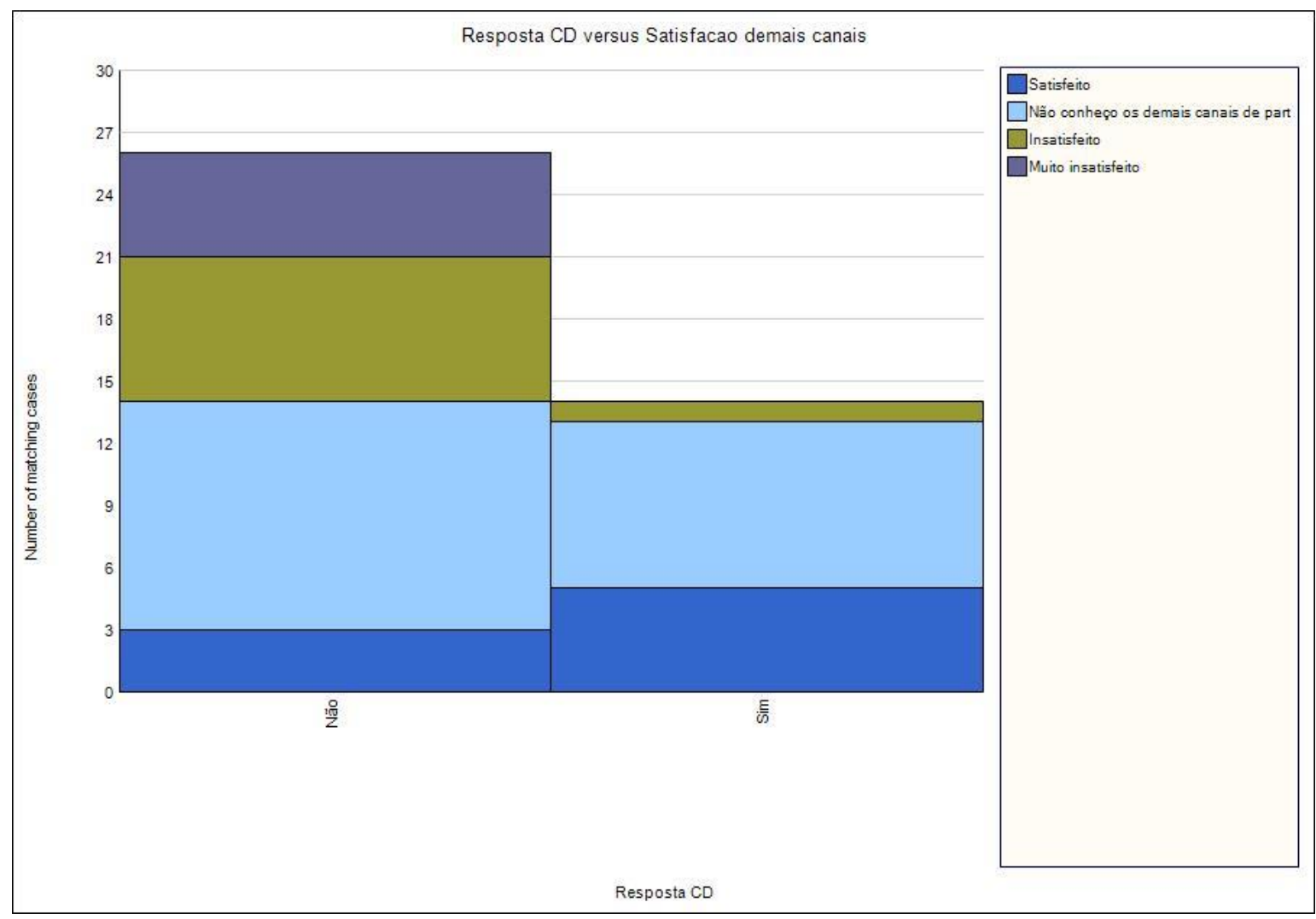

Fonte: elaboração própria.

A quantidade de respondentes insatisfeitos com os demais canais de participação é significativamente maior no grupo de cidadãos que não receberam nenhuma resposta da Câmara dos Deputados às suas manifestações no e-Democracia. Adicionalmente, somente neste grupo há pessoas muito insatisfeitas com os demais canais de participação.

O percentual de respondentes que declararam não conhecer os demais canais de participação é basicamente o mesmo (aproximadamente 50\%) (Figura 43). Portanto, parece não haver relação de causa e efeito entre receber ou não resposta da Câmara às 
manifestações e o desconhecimento dos demais canais. Entretanto, para o grupo de cidadãos que não receberam nenhuma resposta às suas manifestações, o contingente de pessoas insatisfeitas com os demais canais de participação corresponde a $25 \%$, enquanto que para o grupo de pessoas que receberam algum tipo de resposta às suas manifestações o percentual é apenas 6\%, aproximadamente. Em relação aos muito insatisfeitos, o valor é de $20 \%$ neste mesmo grupo, e para o primeiro grupo (que receberam resposta) é de $0 \%$.

Figura 43 - Relação entre resposta da Câmara às manifestações e satisfação com os demais canais de participação (percentuais)

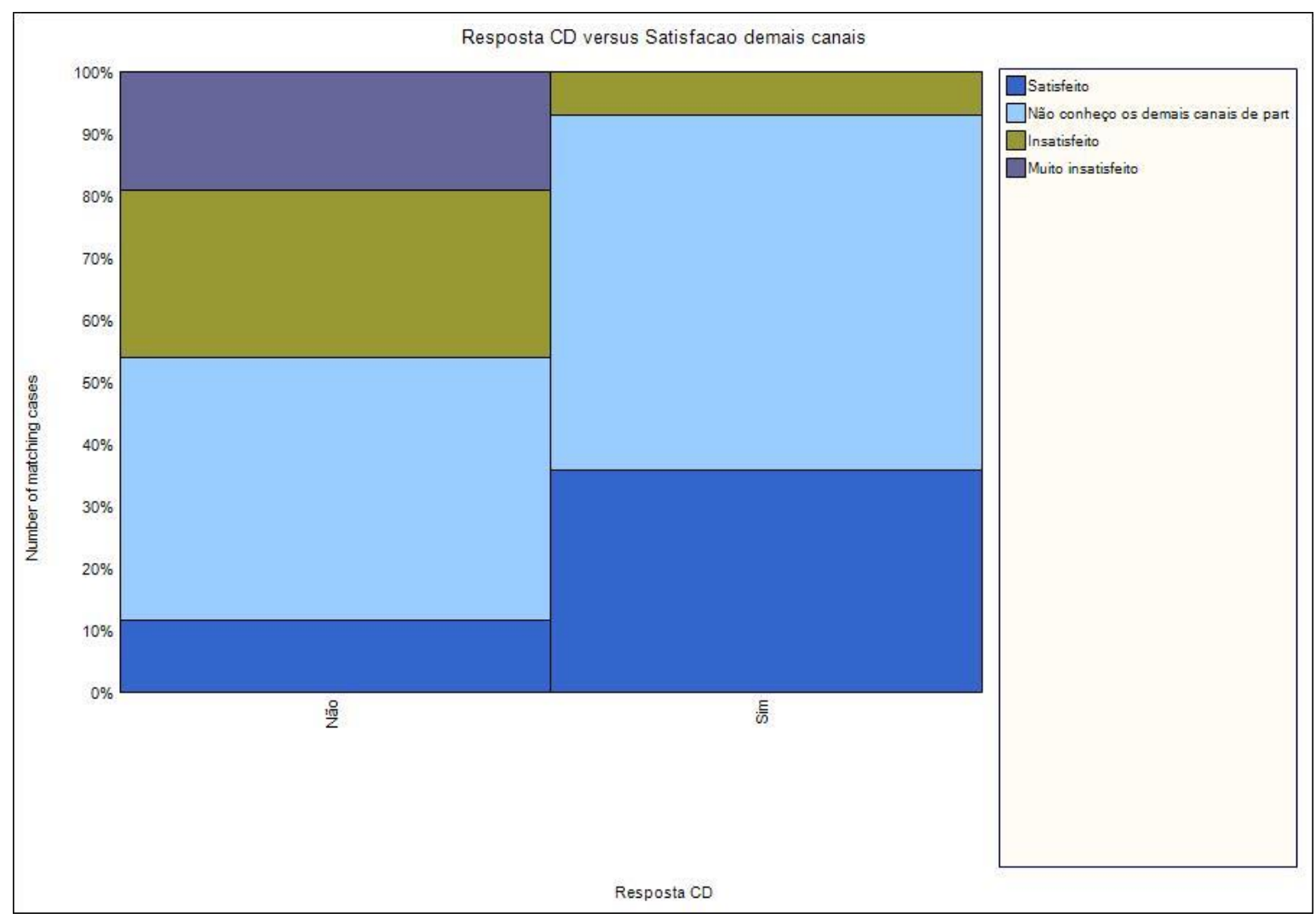

Fonte: elaboração própria.

A figura 44 apresenta um mapa das relações de causalidade identificadas nas análises gráficas anteriores, a partir das respostas ao questionário, e entre elementos de percepção, filiação e comportamento dos cidadãos. No mapa, as setas indicam o sentido da relação causal. Ressalta-se que "causalidade" aqui é entendida em sentido amplo, isto é, diz respeito à maneira específica na qual os eventos (elementos de filiação, percepção e 
comportamento) se relacionam e surgem. Não carrega um sentido "forte" de uma causa que é requisito necessário e suficiente para a ocorrência do efeito. Os efeitos identificados no mapa são explicados apenas em parte pelas causas apontadas. Assim, o elemento de percepção "Não recebeu resposta às manifestações no e-Democracia" é requisito necessário para exista a percepção de que a "participação no e-Democracia é ineficaz", mas não suficiente, pois, por suposto, existem outras causas que também explicam, em parte, a percepção de ineficácia da participação.

Figura 44 - Mapa de relações de causalidade

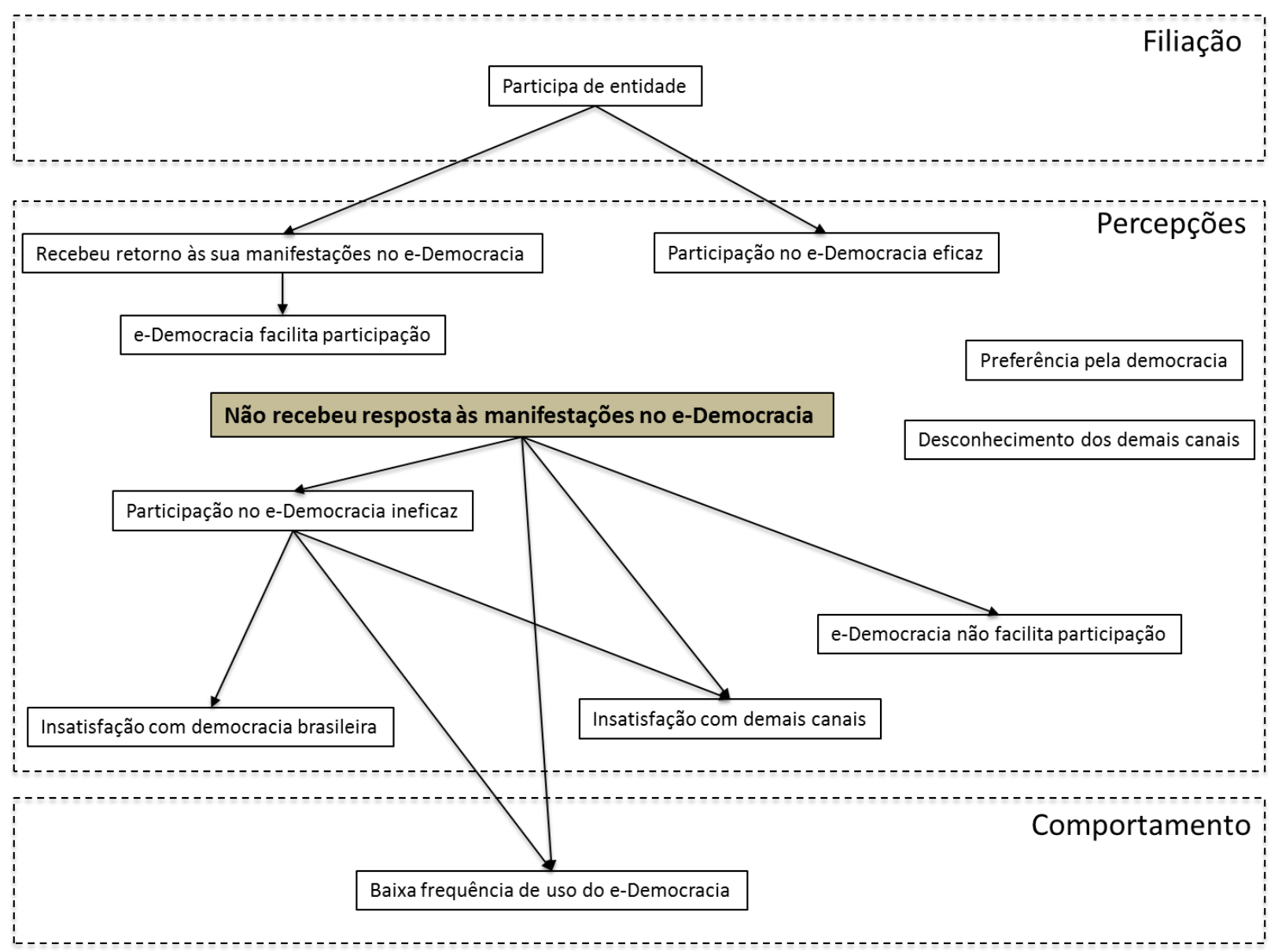

Fonte: elaboração própria.

O elemento de percepção "Não recebeu resposta às manifestações no eDemocracia" é a causa-raiz para vários outros elementos de percepção: "participação no eDemocracia ineficaz”, "insatisfação com democracia brasileira”, "insatisfação com demais 
canais" e "e-Democracia não facilita participação". Significa dizer que esses elementos de percepção podem ser explicados, em parte, pela percepção básica de não ter recebido nenhuma resposta da Câmara dos Deputados às suas manifestações no e-Democracia, o que equivale a afirmar que a ausência de responsividade percebida pelos cidadãosparticipantes funciona como um mecanismo gerativo de um conjunto de percepções negativas sobre a experiência de interagir com a Câmara dos Deputados por meio do portal e-Democracia.

O elemento de percepção "Não recebeu resposta às manifestações no eDemocracia" também contribui para explicar o comportamento de baixo uso, ou uso irregular do portal e-Democracia pelos respondentes.

O mapa também sugere que um elemento de filiação - o fato de pertencer a uma entidade como ONG, movimento social e partido político - pode explicar, em parte, as percepções de que a participação pelo e-Democracia é eficaz e de que a Câmara dos Deputados é responsiva às manifestações dos cidadãos, que, por sua vez, reforça a percepção de que o e-Democracia facilita a participação.

\section{Inclusão}

A partir de registros de dados sociodemográficos de cidadãos que utilizaram o portal e-Democracia, é possível ter uma idéia do perfil desses participantes. É desejável que os cidadãos que interagem com a Câmara dos Deputados sejam representativos da diversidade do conjunto da sociedade brasileira.

\subsection{Perfil dos participantes do e-Democracia}


A Figura 45 apresenta o percentual de respondentes por Unidade da Federação (UF).

Figura 45 - Respondentes por UF

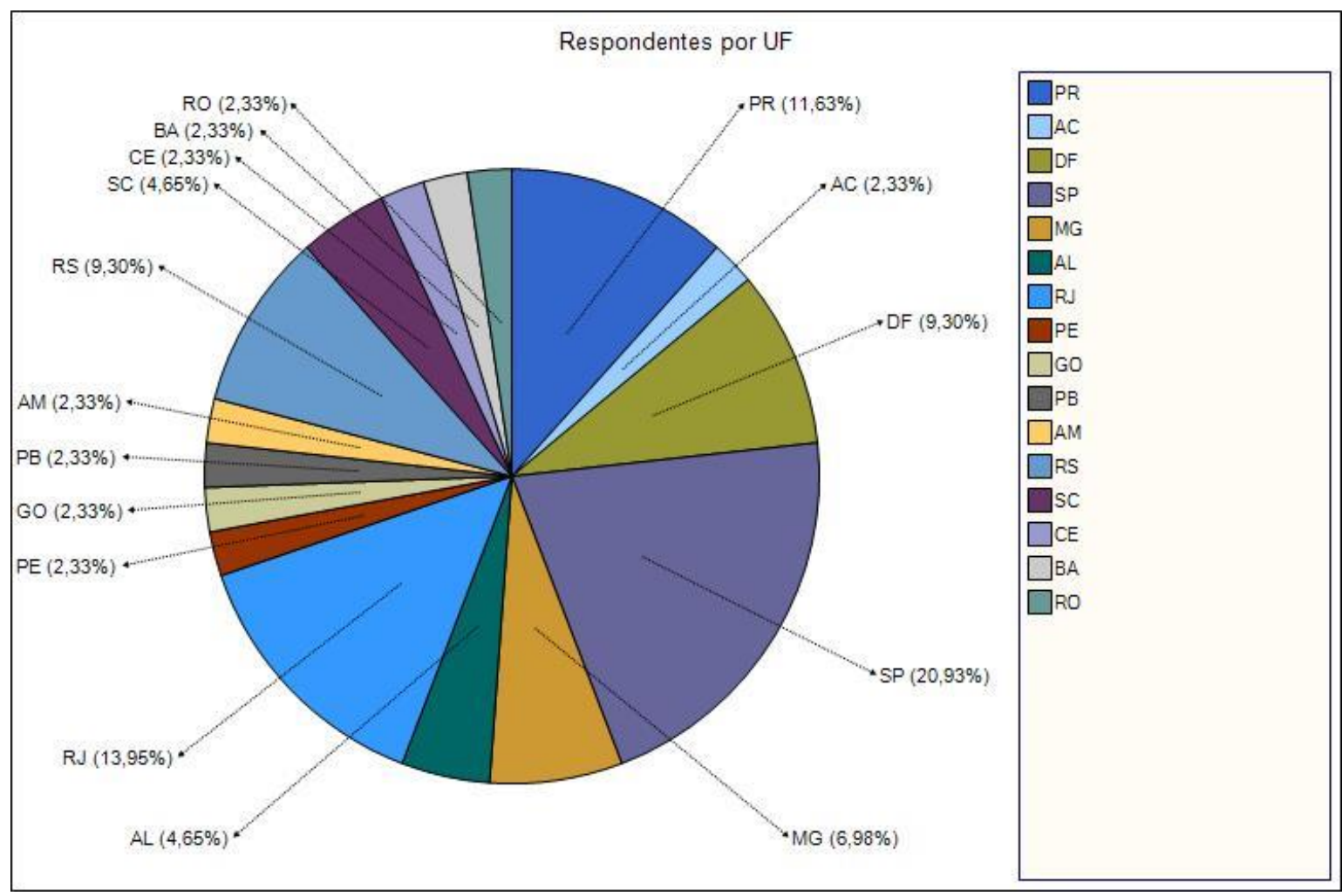

Fonte: elaboração própria.

Nota-se que há representantes das cinco regiões do Brasil, em proporções que tendem a acompanhar o tamanho das populações dos Estados representados. Em que pese o tamanho reduzido da amostra (43 respondentes), a presença de pelo menos um representante de cada região brasileira entre os respondentes pode ser um efeito dos programas de governo para a universalização do acesso à Internet e inclusão digital, a exemplo do Plano Nacional de Banda Larga (PNBL) e o programa Cidades Digitais, que vem priorizando o atendimento às regiões mais distantes e historicamente isoladas das grandes infraestruturas de telecomunicações. A diversidade de Estados da Federação representados pode indicar uma redução significativa da dimensão espacial da exclusão digital. 
Com relação à proporção de homens e mulheres entre os cidadãos que responderam ao questionário, o quadro que surge é de uma acentuada assimetria em favor dos homens (Figura 46). São $86,05 \%$ de homens e apenas $13,96 \%$ de mulheres.

Figura 46 - Proporção de homens e melhores entre os respondentes

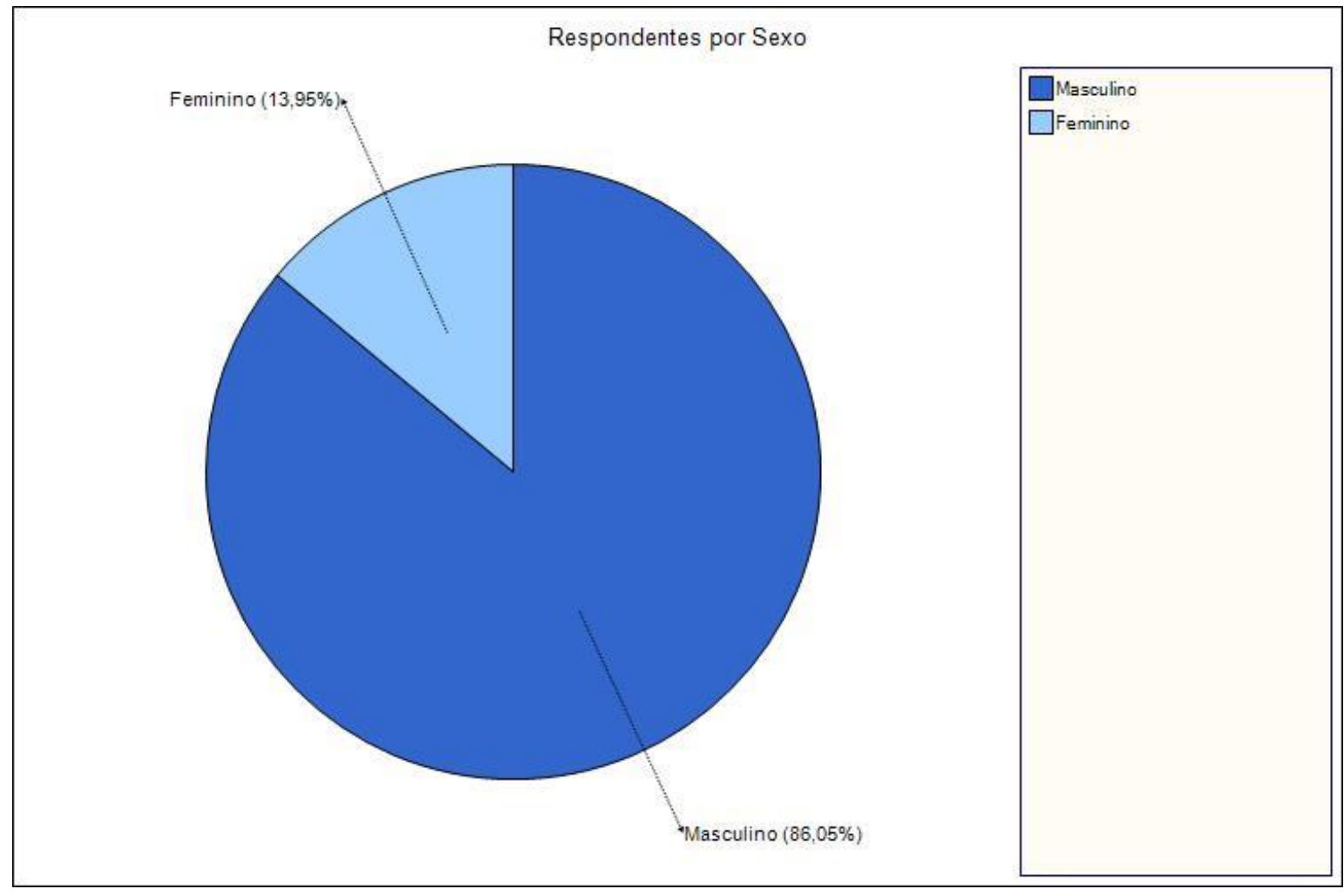

Fonte: elaboração própria.

Segundo dados do Instituto Brasileiro de Geografia e Estatística (IBGE), a população brasileira em 2015 é composta por 100.955.522 homens e 103.495.127 mulheres, o que corresponde em termos percentuais a 49,38\% de homens e 50,62\% de mulheres (IBGE, 2015). Fazendo a devida ressalva sobre o pequeno tamanho da amostra de respondentes, o resultado indica uma aguda subrepresentação das mulheres entre os participantes do portal e-Democracia.

A subrepresentação das mulheres entre os participantes respondentes está próxima da subrepresentação das mulheres entre os deputados, com um contingente de apenas $9,75 \%$ de deputadas.

A Figura 47 resume a distribuição dos participantes por faixa etária. 
Figura 47 - Respondentes por faixa etária

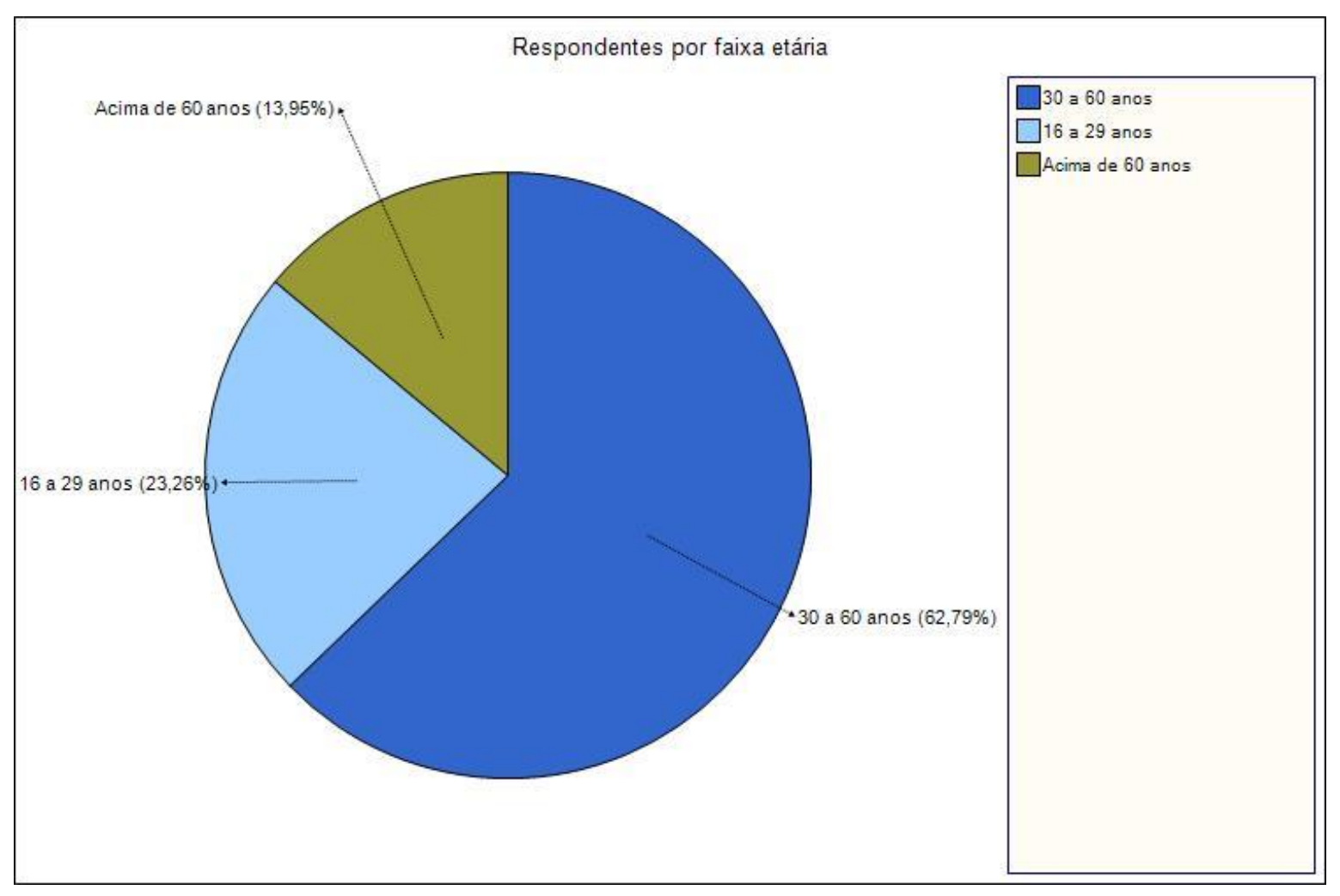

Fonte: elaboração própria.

A maioria dos participantes tem idade entre 30 e 60 anos, totalizando $62,79 \%$ dos respondentes, seguida pela faixa dos 16 a $29 \operatorname{anos}(23,26 \%)$ e acima de 60 anos $(13,95 \%)$.

Finalmente, a distribuição dos participantes por grau de escolaridade (Figura 48). 
Figura 48 - Distribuição dos respondentes por grau de escolaridade

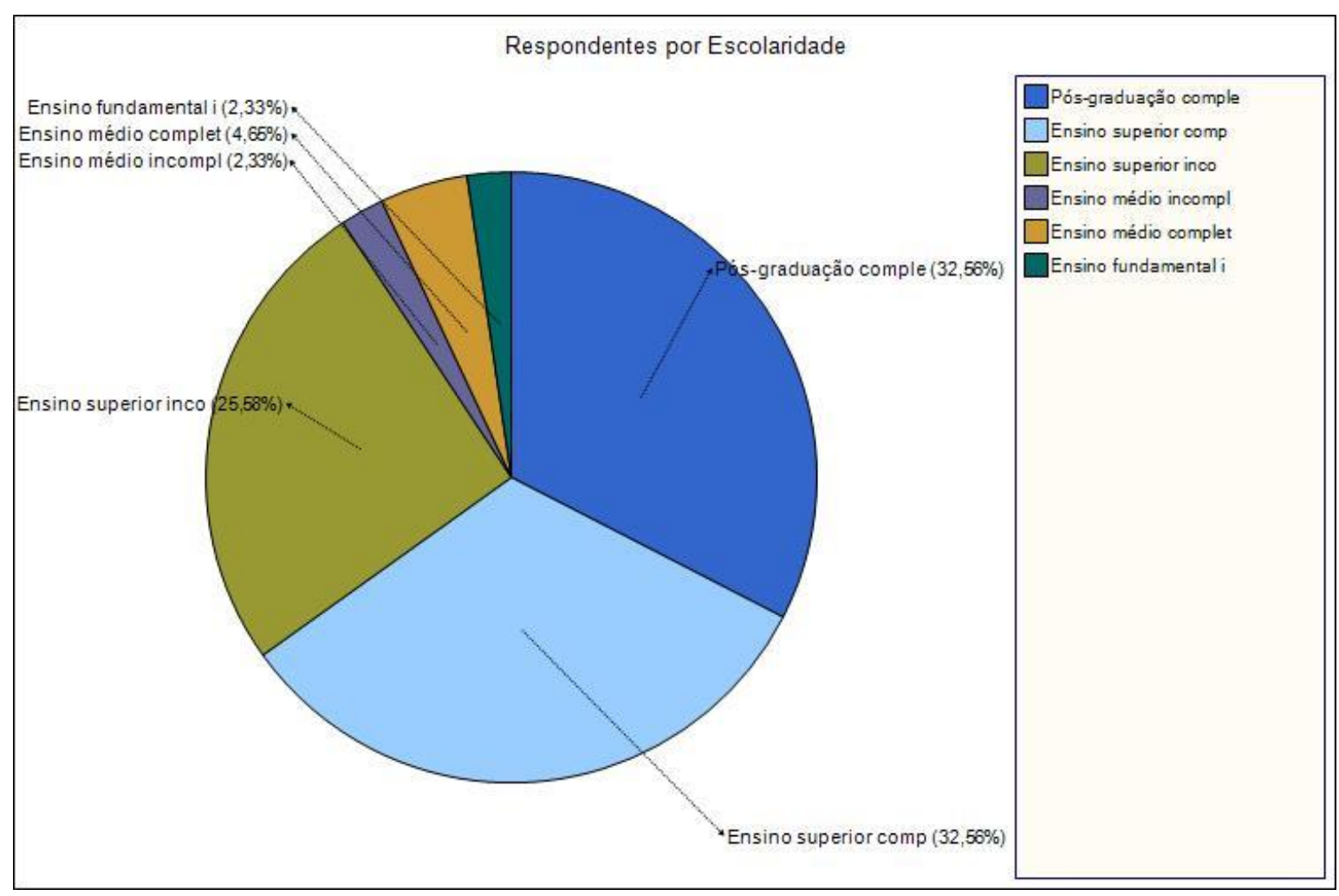

Fonte: elaboração própria.

A partir do gráfico, nota-se que uma expressiva maioria dos participantes, 90,7\%, possui pós-graduação, nível superior completo ou incompleto. Os que possuem nível médio completo corresponde a apenas $4,66 \%$ dos participantes. Este resultado parece apontar para um padrão de exclusão digital para aqueles com baixos níveis de educação formal que, em geral, são pessoas de baixa renda familiar.

O questionário conclui com a seguinte pergunta aberta: "Você teria alguma sugestão para melhorar ou ampliar a participação dos cidadãos no processo político na Câmara dos Deputados?”. Dos 43 respondentes, 34 responderam à pergunta aberta. Estas foram as respostas, com destaques realizados pelo autor da pesquisa:

1. Acho interessante maior divulgacão do e-Democracia e da programação da TV Câmara entre os professores e estudantes, principalmente de ensino médio e superior. Percebi que mesmo nos 
cursos de ciências sociais a maioria dos professores não estimula os alunos a assistir a TV Câmara, preferindo discutir notícias distorcidas veiculadas pelos grandes jornais, por exemplo. Uma estratégia poderia ser bolar um concurso em nível nacional que envolvesse esse público.

2. A participacão é nula se não for seriamente considerada pelos parlamentares.

3. SERMOS OUVIDOS.

4. PARLAMENTARISMO.

5. As sugestões populares poderiam ser mais discutidas pelos parlamentares. Como por exemplo, uma sessão específica para isso.

6. Se eu falar o que penso, logo outro mais bem requisitado da "democracia" dos que detém o poder vai me ofuscar com sua incrível opinião de mais do mesmo. Não obrigado, não acredito nessa ferramenta... ninguém acredita. Porque essa democracia que se pensa simplesmente não existe.

7. Sou a favor da criação de uma norma geral para assegurar a todos os cidadãos mecanismos básicos de participacão via internet nas Câmaras Municipais e nas Assembleias Legislativas. Sugiro a criacão de um cadastro geral em que o eleitor em dia com suas obrigações eleitorais se apresentaria em qualquer casa legislativa do país portando o seu título, faria um cadastro presencial, registraria sua senha e, por meio de um sistema único, passaria a ter acesso participativo tanto na Câmara Federal, como na Assembleia Legislativa e Câmara Municipal de sua cidade. Com isso, as enquetes e demais tipos de consulta ganhariam maior validade e estaríamos valorizando mais o título eleitoral como documento dando a ele um uso mais amplo e destinado ao exercício da democracia.

8. De nada vai adiantar os canais se os parlamentares não nos derem ouvidos. 
9. O problema não necessariamente está nos meios de participação popular com a Câmara, mas no fato de os deputados ignorarem o que é debatido lá. Como exemplo cito a reforma política que foi votada pelos deputados, os quais ignoraram muito do que foi debatido no fórum do e-democracia e acabaram formulando uma reforma que era única e exclusivamente do interesse deles, deixando de lado o interesse da população.

10. Voto distrital.

11. Que se abrisse um canal de debates com temas de interesse geral que mexeria com a vida das pessoas.

12. Reforma eleitoral que impeca o poder econômico.

13. Que seja implantada a assinatura de projetos via internet.

14. INTERAC̃̃̃O DOS POLÍTICOS.

15. Já falei tudo no e-Democracia em 2013... no da Reforma Política...

16. Que o eleitor receba relatórios dos votos do seu $\underline{\text { deputado }}$ e que possa responder enquetes para nortear os votos do seu representante.

17. Que a Câmara se torne mais próxima dos cidadãos, em especial no interior do país, com a descentralização de comissões e audiências públicas.

18. Democracia participativa e não representativa.

19. Sim. Gostaria que os participantes pudessem participar de uma audiência pública ou congresso sobre o tema na Câmara dos Deputados ou Senado Federal.

20. Sim. Precisamos realizar um grande encontro com os cidadãos participantes deste canal, a fim de discutir qual é o Congresso Nacional que nós queremos que nos represente. 
21. Trazer as comissões da câmara dos deputados para dentro dos municípios dos estados brasileiros através de eventos ao ar livre com debates.

22. Criação de um programa em forma de telejornal na TV Câmara para exibir as votações diárias e as posições e como cada um dos deputados federais votaram.

23. Acredito que a divulgação e a formação politizada nas escolas desde o ensino básico até a pós graduação seria um avanço para a participação popular.

\section{SIM. PARLAMENTARISMO MONÁRQUICO.}

25. Cada deputado deveria direcionar uma parte da verba destinada ao gabinete para financiar um instituto de pesquisa que mensure a interação popular com o legislativo por região, onde os valores gastos devem obedecer as leis de transparência publica, também para criação de um portal que amplamente divulgue a decisão de cada voto do politico em cargo legislativo para que se possa junto aos órgãos de pesquisa relacionar as atividades legislativas ao interesse popular.

26. Democracia mais direta com a participação mais efetiva no resultado das votaç̃̃es que decidem o futuro do país.

\section{Mais espaço para votação do público.}

28. Fim do financiamento empresarial de campanhas.

29. Fazer com que os deputados tenham obrigacão de ler e dar feedback sobre as propostas. talvez, até mesmo dar poder de voto para a participação popular.

30. Plebiscitos. Previsto na Constituição e eles não fazem.

31. Deveria haver uma divulgacão maior a respeito das sugestões populares neste canal. Sei que minha sugestão foi igual a muitas, no entanto, não sei bem a conta exata. Seria interessante para que, 
de alguma forma, a sociedade ficasse sabendo e, assim, poderia pressionar mais estes representantes do "povo".

\section{Democracia Direta.}

33. Sim. Várias sugestões.

34. Prezados, a população do Brasil, ao mesmo tempo que se compõe como civilização, de outra forma se deteriora pelo fomento de que nada é possível, que tudo está dominado pela "fraude e corrupção" e, quem não faz fraude ou corrupção é tido como IMBECIL e que não adianta, o Brasil é assim mesmo. Pasmem, isso são formas de expressão posta por muitos engenheiros, advogados, contadores e por aí vai, em todas as profissões consideradas "Regulamentadas", e não são apenas um ou dois. São milhares destes. Sabem quando a participação popular entenderá o que é um processo político ? O dia em que a Justiça for realmente digna e moralizada. Não gostaria de escutar quando Eu dissesse para alguém que é crime fazer licitação sem ter recursos para pagar e o objeto licitado, e este me respondesse que demoraria muito tempo Eu denunciar e alguém abrir processo. Sabem por que ele falou isso ? por que faz parte daqueles grupos que estão em todas as instituições e se protegem como "amigos íntimos", aqueles que roubam a dignidade humana. É por isso que há dificuldades de maiores participações Democráticas e de Credibilidade vista pela população.

Ao tentar estabelecer conexões do conteúdo das respostas com as dimensões da escolha descritas na abordagem Choice Framework, nota-se que alguns diagnósticos e algumas propostas de intervenção dizem respeito à dimensão do "senso da escolha", isto é, que os cidadãos saibam da existência dos canais digitais de interação da Câmara dos Deputados com a sociedade. Ações para maior divulgação dos espaços digitais existentes de participação cidadã vão no sentido de fortalecer o senso da escolha. A formação politizada nas escolas (resposta 23).

Algumas respostas trazem propostas de criação de novos canais e espaços institucionalizados para a participação. Em termos das dimensões da escolha, tais proposições afetariam a dimensão da "existência de escolha", ao ampliar o leque de 
instituições participativas. Fazem parte desse grupo as propostas, por exemplo, de criação de um cadastro geral... para ter acesso participativo na Câmara Federal (resposta 7), de abertura de um canal de debates com temas de interesse geral (resposta 11) e de implantação de assinatura de projetos via Internet (resposta 13).

Contudo, um ponto se destaca na maioria das respostas: a preocupação com a efetividade da participação e a responsividade dos deputados aos cidadãos. O conjunto de diagnósticos e propostas de intervenção desse grupo de respostas teriam um impacto na dimensão da "Realização da escolha". Em termos de diagnósticos realizados pelos respondentes, estão a percepção de que a participação será "nula" (leia-se: inefetiva) se não for seriamente considerada (responsividade) pelos parlamentares (resposta 2), o desejo de ser ouvido (resposta 3) e de que os parlamentares discutam mais as sugestões populares (resposta 5), a conclusão que "de nada vai adiantar os canais se os parlamentares não nos derem ouvidos" (resposta 8), o problema dos deputados ignorarem o que é debatido nos meios de participação popular na Câmara (resposta 9), o clamor por interação dos políticos (resposta 14) e para que a Câmara se torne mais próxima dos cidadãos (resposta 17). Também o anseio por uma "participação mais efetiva no resultado das votações que decidem o futuro do país" (resposta 26) e a sugestão de "fazer com que os deputados tenham obrigação de ler e dar feedback sobre as propostas" (resposta 29).

Este conjunto de manifestações e expressões, entre diagnósticos, sentimentos impotência e ceticismo (resposta 6) e sugestões de intervenções, alinham-se aos resultados obtidos na análise da responsividade dos deputados federais, muito mais direcionada às preferencias e interesses do mercado do que às preferências e interesses dos cidadãos. Essa baixa responsividade dos deputados aos cidadãos seria um dos mecanismos gerativos que estaria na raiz da reduzida efetividade da participação popular, percebida pelos respondentes e evidenciada no conteúdo de suas respostas. 


\title{
PARTE V - DISCUSSÃO: PARTICIPAÇÃO E DESENVOLVIMENTO NA CÂMARA
}

\begin{abstract}
Retornando às distinções sugeridas por John Martinussen entre conceito (objetivo) de desenvolvimento, teoria de desenvolvimento e estratégia de desenvolvimento, representadas na Figura 5, a presente pesquisa partiu, inicialmente, da idéia de desenvolvimento proposta por Amartya Sen como um processo de expansão das liberdades ou oportunidades (escolhas) substantivas de um indivíduo para ser ou fazer aquilo que tem razões para tanto. O objetivo do desenvolvimento seria essa ampliação das oportunidades ou escolhas. Para o objeto de pesquisa da presente tese, a ampliação das oportunidades corresponde ao conjunto de possibilidades reais de influenciar - participar - o processo político que acontece na Câmara dos Deputados.
\end{abstract}

As possibilidades de influenciar o processo político apresentam-se na forma de graus de empoderamento do cidadão, o que na linguagem do modelo Choice Framework proposto por Dorothea Kleine corresponde às quatro dimensões da escolha - existência, senso, uso e realização da escolha -, mapeadas da seguinte forma ao objeto da presente pesquisa:

- Existência de escolha - Existência de canais de interação da Câmara dos Deputados com a sociedade;

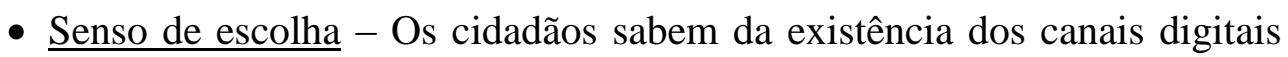
de interação da Câmara dos Deputados com a sociedade;

- Uso da escolha - Os cidadãos fazem uso efetivo dos canais digitais disponibilizados;

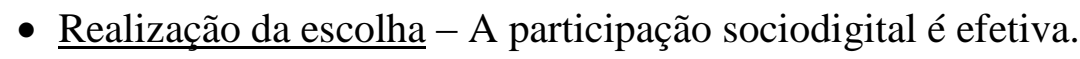

A tabela a seguir traz um resumo da análise do desenvolvimento humano nas quatro dimensões da escolha: 
Tabela 19 - Resultados da análise de desenvolvimento humano

\begin{tabular}{|l|l|c|}
\hline Dimensões da escolha & Análise para a Câmara dos Deputados & Conclusão \\
\hline Existência de escolha & $\begin{array}{l}\text { Existência de vários canais de } \\
\text { participação: e-Democracia, Disque- } \\
\text { Câmara, Fale Conosco, Fale com o } \\
\text { Deputado, Facebook, Twiter e CLP. }\end{array}$ & OK \\
\hline Senso de escolha & $\begin{array}{l}\text { Cidadãos conhecem o e-Democracia, } \\
\text { mas desconhecem os demais canais de } \\
\text { participação disponibilizados pela } \\
\text { Câmara dos Deputados. }\end{array}$ & Parcialmente OK \\
\hline Uso da escolha & $\begin{array}{l}\text { e-Democracia é utilizado raramente ou } \\
\text { de forma ocasional. }\end{array}$ & Não OK \\
\hline Realização da escolha & $\begin{array}{l}\text { Inefetividade da participação - } \\
\text { reduzida capacidade de influenciar a } \\
\text { atuação dos deputados. }\end{array}$ & Não OK \\
\hline
\end{tabular}

Fonte: elaboração própria.

Os resultados da análise do desenvolvimento humano para a Câmara dos Deputados revelam, primeiramente, que para o canal apreciado pela pesquisa, os cidadãos não estão significativamente empoderados quanto ao "uso da escolha" e "realização da escolha”. Em relação à dimensão do uso da escolha, a utilização do e-Democracia é, majoritariamente, rara ou ocasional. Quanto à realização da escolha, os cidadãos percebem que não conseguem converter suas manifestações no e-Democracia em influência sobre a atuação dos deputados.

No que tange à dimensão do "senso de escolha", os cidadãos que utilizaram ao menos uma vez o e-Democracia desconhecem, em sua maioria, os demais canais de participação existentes na Câmara dos Deputados. Esse resultado aponta para uma deficiência, por parte da Câmara, na divulgação dos demais canais para a sociedade em geral. A única dimensão da escolha na qual os cidadãos encontram-se plenamente empoderados é a "existência de escolha": há uma profusão de canais de participação sociodigital instituídos pela Câmara dos Deputados.

É possível representar as dimensões da escolha em termos de zonas concêntricas de protagonismo cívico na esfera pública (Figura 49), com graus crescentes de 
empoderamento e apropriação social do poder político à medida em que se caminha da zona mais externa (existência da escolha) até o núcleo do sistema onde são tomadas as decisões políticas e onde existe a possibilidade de realização da escolha, ou seja, de influenciar tais decisões.

Figura 49 - Zonas de protagonismo cívico

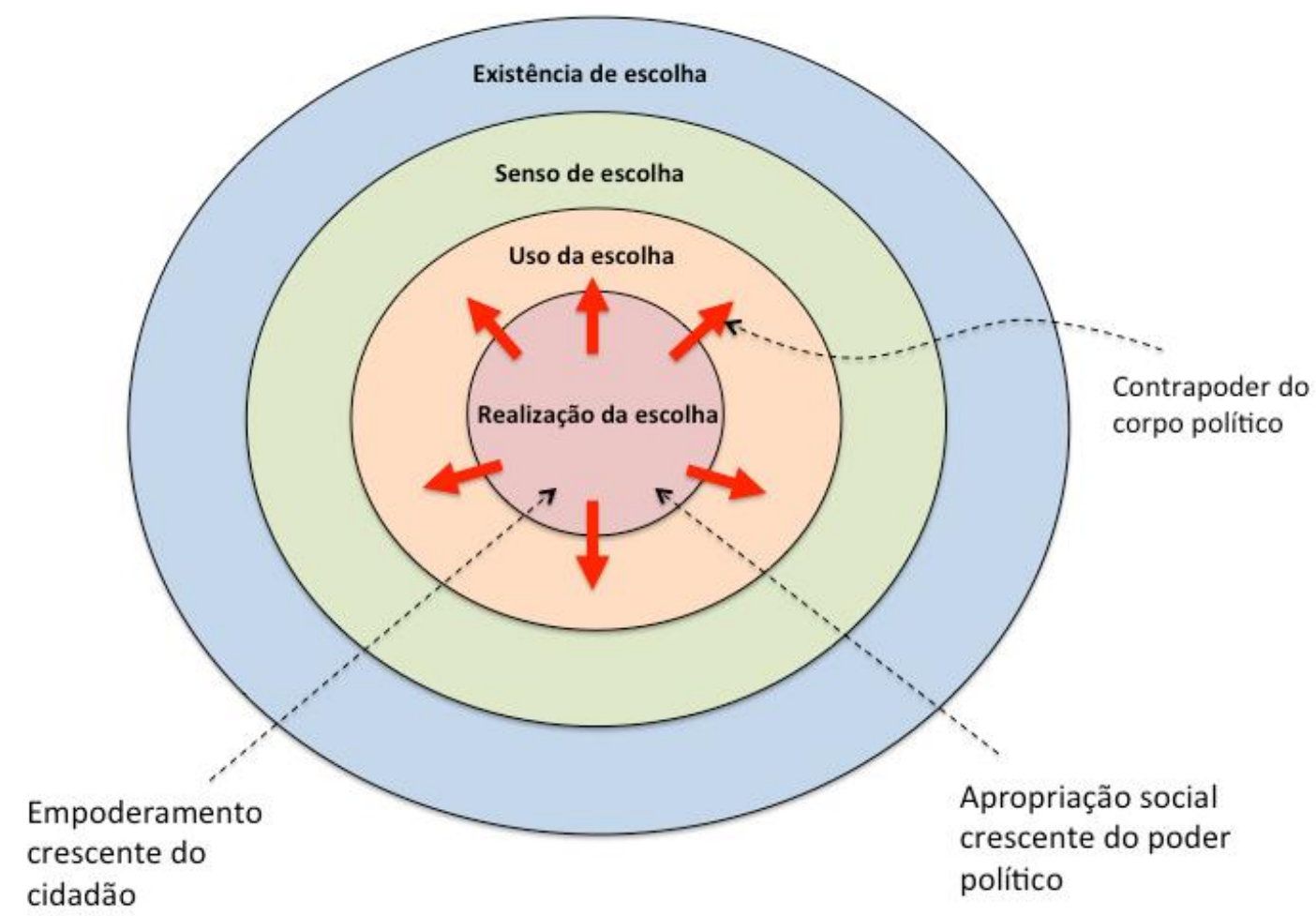

Fonte: elaboração própria.

Enquanto as iniciativas de democracia digital permanecem restritas às zonas mais externas da construção e divulgação de ferramentas e espaços de interação Parlamentosociedade mediada pelas TICs, e o ativismo cívico dos cidadãos não ultrapassa a fronteira da mera utilização de tais ferramentas e espaços participativos, são eventuais ou inexistentes as ações de resistência ou contrapoder (CASTELLS, 2009) dos políticos profissionais para salvaguardar suas quotas de poder. As três primeiras zonas de protagonismo cívico formam a região do território da cidadania não colonizada ou fracamente colonizada pelo sistema político. Esta parte do território da "cidadania" é ativamente produzida por uma ordem legal, que lhe dá existência e forma, estabelecida e mantida por atores sociais com quotas substantivas de poder político, que lhes permitem participar da concepção e construção dos principais desenhos institucionais, nos níveis 
constitucional, legal e infralegal, que serão, por seu turno, indutores de papéis ou representações sociais e do conjunto de relações associadas, que costumamos chamar de estrutura social.

O ativismo dos cidadãos que habitam esta parte do território da "cidadania" está associado ao exercício de funções marginais dentro do sistema político, essencialmente voltado para o consumo de informações produzidas pelas instituições da democracia representativa e pelo uso dos canais de interação institucionalizados. Esta subcidadania, com atuação nas franjas do sistema, é precisamente a característica distintiva de um grupo social denominado de "ralé” por Jessé Souza (2003).

O efeito "colonizador do sistema político sobre o território dos direitos de participação direta e efetiva do cidadão nos negócios públicos" (MAIA; GOMES; MARQUES, 2011, p. 25) se torna mais aparente quando os cidadãos adentram a zona mais interna da "realização da escolha" e passam a reivindicar e pressionar as instituições da democracia representativa por uma participação mais efetiva em termos de influência sobre as decisões políticas. Esta postura dos cidadãos é, em geral, interpretada pelos políticos profissionais como uma invasão de fronteiras, na trama dos papéis, que aciona as luzes de alerta de uma ameaça externa às suas posições consolidadas de poder político. Ações de contrapoder são iniciadas.

O quadro geral aponta para uma condição de subdesenvolvimento humano, já que os esforços de participação dos cidadãos não se traduzem em capacidade de influenciar as decisões políticas na Câmara dos Deputados.

$\mathrm{Na}$ acepção de Martinussen, uma teoria de desenvolvimento busca respostas sobre como o(s) objetivo(s) de desenvolvimento escolhido(s) pode(m) ser promovido(s) ou obstruído (s) e prejudicado(s). Procura identificar relações causais e fatores explicativos para o processo de mudança social, e os principais atores que exercem papéis dominantes, e que interesses eles têm. Neste sentido, a presente pesquisa é um exercício de teoria do desenvolvimento, na medida em que tenta encontrar tais respostas para o objetivo de ampliação das oportunidades de influenciar o processo político que ocorre na Câmara dos Deputados. 
Os principais resultados encontrados pela pesquisa podem ser assim resumidos:

- As análises dos conteúdos das respostas ao questionário e das entrevistas apontam para uma baixa efetividade da participação sociodigital na Câmara dos Deputados, isto é, os cidadãos estão significativamente limitados em sua capacidade de influenciar o processo político. Como parte significativa das pretensões dos indivíduos em ser e fazer o que tem razões para tal, num regime democrático, são impactadas pelo conjunto das leis e normas criadas no Legislativo, este primeiro resultado equivale a afirmar que o objetivo de desenvolvimento de ampliação das liberdades substantivas dos cidadãos em interferir no processo legislativo encontra-se significativamente prejudicado.

- $\quad \mathrm{Na}$ raiz do problema, no nível das estruturas, a pesquisa intensiva (qualitativa) identificou a quase completa ausência de responsividade (atenção, retorno, resposta, feedback) dos deputados federais às demandas e contribuições dos cidadãos pelos canais de interação da Câmara com a sociedade, particularmente o portal e-Democracia.

- $\quad$ Os resultados da análise quantitativa do financiamento empresarial de campanhas e o comportamento parlamentar corroboram os resultados obtidos na análise qualitativa, revelando significativa responsividade dos deputados aos interesses e preferências do mercado e, consequentemente, reduzida responsividade aos interesses e preferências dos cidadãos. Os resultados apontam também para uma relação estatisticamente significativa e crescente entre probabilidade de cooperação dos deputados com os interesses do mercado e a proporção de recursos financeiros oriundos de empresas do setor industrial e da proporção de recursos financeiros em relação ao total arrecadado pelos deputados eleitos na campanha de 2014 (uma medida de quão cara foi a campanha eleitoral de um deputado). Finalmente, a análise quantitativa aponta para uma relação crescente entre o grau de responsividade ao mercado e a proporção dos recursos financeiros recebidos de pessoas jurídicas em geral.

- $\quad$ O elemento estruturante do direcionamento da responsividade dos deputados para os interesses e preferencias do mercado cria o mecanismo gerativo da ausência de retorno ou resposta dos deputados às demandas dos cidadãos que, por sua vez, contribui para reforçar os efeitos (eventos) da (1) percepção de que o 
corpo político não é responsivo aos cidadãos, (2) percepção de que a capacidade de agir do cidadão é muito reduzida e (3) o surgimento de uma não regularidade na utilização do portal e-Democracia.

- $\quad$ Outro fator estruturante que pode ser parte da explicação para a baixa efetividade da participação sociodigital percebida é um sentimento de insatisfação generalizada com o funcionamento da democracia brasileira, que está por trás dos mecanismos gerativos dos sentimentos de descrença nas instituições da democracia representativa e impotência frentes aos demais atores que detém o poder político. Estes sentimentos, por sua vez, também contribuem para reforçar a percepção de que a capacidade de agir do cidadão é muito pequena e o padrão de uso não regular do portal e-Democracia.

A Figura 50 apresenta um resumo dos resultados da pesquisa, segundo a estratificação da realidade social nos domínios do empírico, do realizado e do real, onde encontram-se os eventos, os mecanismos gerativos e as estruturas, respectivamente.

Figura 50 - Resumo dos Resultados da pesquisa

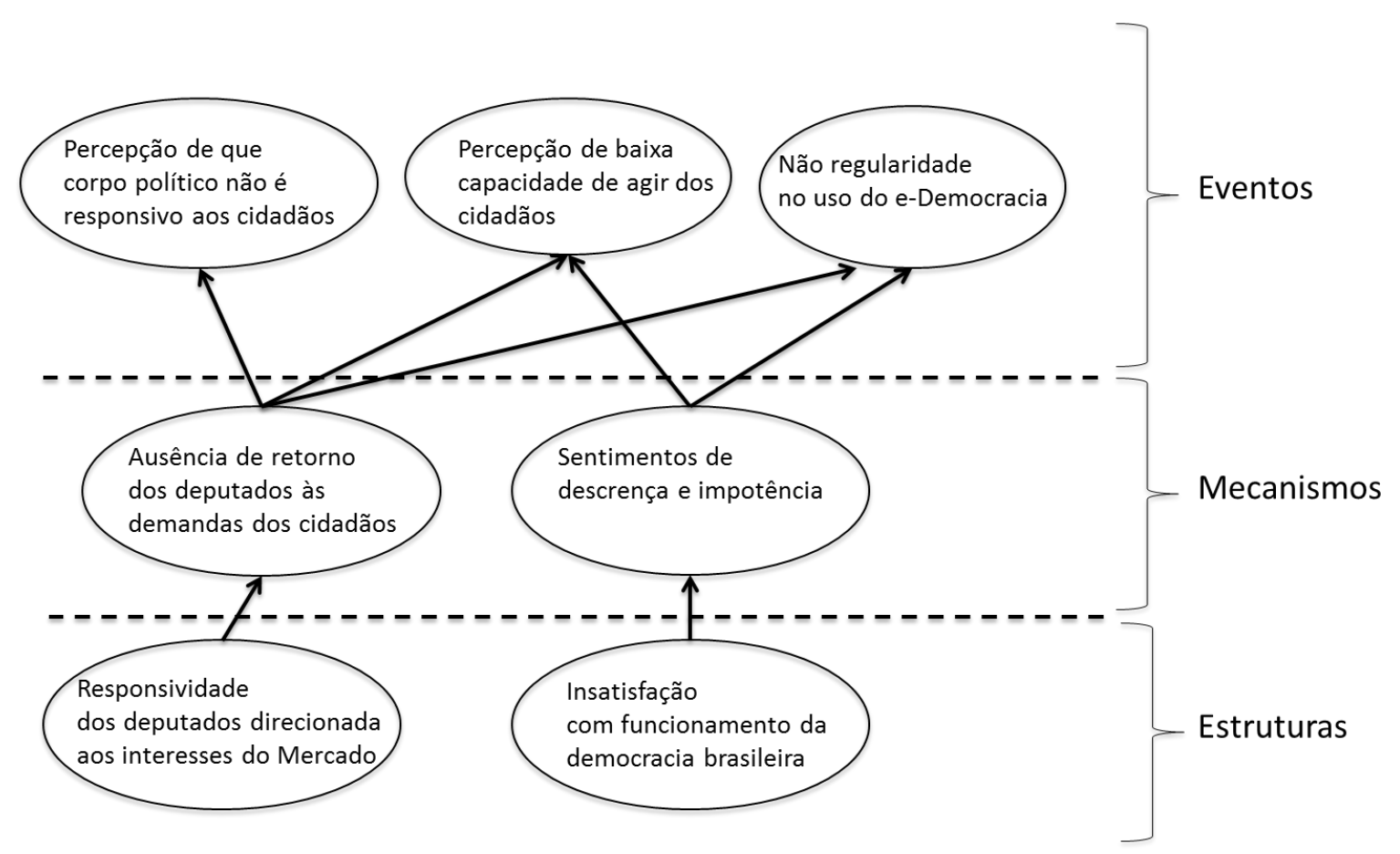

Fonte: elaboração própria. 


\section{Considerações finais}

Os resultados obtidos trouxeram significativas evidências de uma inefetividade da participação sociodigital na Câmara dos Deputados, em relação à capacidade dos cidadãos de influenciar as decisões do corpo político.

Em exercício de retrodução - modo de inferência pelo qual tentamos chegar naquilo que é basicamente constitutivo e característico das estruturas -, a pesquisa permitiu identificar dois fatores explicativos, estruturais e estruturantes desta inefetividade da participação: o direcionamento da responsividade dos deputados federais aos interesses e preferências dos atores do mercado, em prejuízo da atenção necessária aos interesses e demandas dos cidadãos, e o sentimento de insatisfação generalizada em relação ao funcionamento da democracia brasileira.

A identificação de elementos estruturais, especialmente o direcionamento da responsividade dos deputados aos interesses de atores do mercado como fatores explicativos para a percebida inefetividade da participação sociodigital, contrapõe-se ao naturalismo - tendência moderna de desvincular a ação e a experiência humana da moldura contextual que lhe confere realidade e compreensibilidade.

A observada inefetividade da participação popular contribui para a produção de uma subcidadania (SOUZA, 2003), condição na qual os cidadãos não conseguem exercer de forma significativa sua autonomia política e o autogoverno. Tal condição surge a partir da dificuldade de influenciar o comportamento dos representantes eleitos, durante o exercício do mandato parlamentar, fracassando na tentativa de sensibilizá-los para seus interesses.

Partindo da afirmação de Kelsen de que "Politicamente livre é quem está sujeito a uma ordem legal de cuja criação participou" e com base nos resultados da pesquisa, podese descrever o cidadão que interage com o sistema político da Câmara dos Deputados através do canal e-Democracia como um “dependente formalmente livre”. Esta expressão, 
cunhada por Jessé Souza, descreve o indivíduo como um "despossuído formalmente livre, cuja única chance de sobrevivência era ocupar funções nas franjas do sistema" (2003, p. 121).

No caso estudado, o cidadão encontra-se limitado em seu autogoverno e sua autonomia política, relegado a ocupações marginais dentro do sistema político, reduzindo sua capacidade de exercer influência significativa sobre a criação da ordem legal. Esta condição de dependência que o leva a uma atuação nas franjas do sistema, constitui-se na principal característica do grupo social designado por Jessé Souza como "ralé" - "seres dispensáveis na medida em que não exercem papéis fundamentais para as funções produtivas essenciais e que conseguem sobreviver nos interstícios e nas ocupações marginais da ordem produtiva" (2003, p. 121).

Neste sentido, a inefetividade da participação sociodigital é produtora de uma ralé composta por um contingente de cidadãos-dependentes, despossuídos dos recursos materiais e legais que poderiam reposicioná-los como atores centrais no jogo político, cuja relativa "dispensabilidade" econômica frente a atores do mercado converte-se em dispensabilidade política.

A assimetria de poder entre atores do mercado e os cidadãos, traduzida em graus distintos de eficácia na tentativa de influenciar as decisões políticas, contribui decisivamente para violar o princípio da igualdade política de "uma pessoa, um voto", criando as condições materiais para o surgimento da subcidadania dos despossuídos formalmente livres.

A subcidadania política manifesta-se como subdesenvolvimento humano, a condição na qual os indivíduos se acham limitados em suas oportunidades reais de escolher a vida que imaginam e buscam para si, posto que encontram-se constrangidos em sua capacidade de participar ativamente da criação da ordem legal à qual estarão sujeitos. Como destacado por Coleman e Blumler, a pergunta-chave para se avaliar projetos e iniciativas de democracia digital - a exemplo do portal e-Democracia - é "se existem evidências de que os cidadãos se sentem mais influentes em relação às decisões que governam suas vidas" (COLEMAN; BLUMLER, 2009). As evidências produzidas durante 
a pesquisa reforçam a tese da subcidadania e do subdesenvolvimento humano para o universo da participação sociodigital na Câmara dos Deputados.

Adicionalmente, a pesquisa revelou que a mera existência de inúmeros canais digitais de interação com a sociedade não promove, necessariamente, uma maior participação popular no processo político que acontece na Câmara dos Deputados. Assim, em termos de efetividade da participação, as iniciativas e investimentos em democracia digital devem priorizar ações orientadas a redirecionar a responsividade política dos parlamentares aos interesses e demandas dos cidadãos. Dada a assimetria de poder entre cidadãos e empresas, uma ação neste sentido seria o fim do financiamento empresarial de campanhas eleitorais. Tal intervenção poderia significar uma mudança considerável nas regras do jogo, e o início de um resgate do princípio da igualdade política de "uma pessoa, um voto", dando-lhe concretude.

Há que se destacar que a subcidadania e o subdesenvolvimento não é experimentado da mesma maneira e na mesma intensidade pelos diversos grupos sociais. Como apontado pela análise de inclusão, a subrepresentação das mulheres entre os cidadãos-participantes e entre os deputados agrava a condição de vulnerabilidade da mulher para a realização da vida que imagina e busca para si. Aqui, as políticas de quotas para a ampliação da presença feminina nos espaços de poder podem ser decisivas. A importância de tais políticas está na possibilidade de realização da autonomia política para as mulheres. Nas palavras de Luiz Felipe Miguel,

A ação afirmativa é uma tentativa de romper este círculo vicioso, contribuindo para a redistribuição do capital político — ou, dito de outra forma, para o "empoderamento" (empowerment) dos segmentos sociais marginalizados. Em suma, ela se sustenta com a constatação da desigualdade presente na sociedade, sem necessitar de qualquer argumento essencialista ou da crença na "objetividade" de interesses comuns ao grupo. Neste sentido, as vozes das mulheres na política são, sim, "vozes diferentes". Não porque a diferença sexual produza uma singularidade moral, mas porque a organização da sociedade impõe experiências de gênero diferenciadas. A presença das vozes das mulheres - e de outros grupos excluídos politicamente - no debate público representa, então, um passo na direção da realização da democracia, 
entendida no seu sentido de "autonomia", isto é, a possibilidade de que os cidadãos e cidadãs fixem, eles próprios, as normas que regerão as suas vidas. (MIGUEL, 2001, p. 266).

Ressalta-se que as inferências, considerações e conclusões deste exercício de teoria do desenvolvimento, estão, a rigor, vinculadas ao caso concreto e particular estudado e às limitações encontradas durante o experimento. Dentre as limitações, destaca-se o pequeno leque de matérias legislativas analisadas (três matérias), que produziu, por conseguinte, uma série histórica de votos nominais também relativamente pequena (1265 votos). A ocorrência das votações numa mesma legislatura é outra especificidade da pesquisa.

Sugere-se, portanto, que a atual pesquisa seja complementada com a ampliação da quantidade de matérias legislativas investigadas; a combinação de matérias com votações em legislaturas distintas; e a inclusão de mais canais digitais, além do e-Democracia, na análise qualitativa. Isto permitiria uma exploração do objeto da pesquisa em bases empíricas ampliadas.

Finalmente, em que pese as restrições e especificidades já ressaltadas, espera-se que o presente trabalho de pesquisa tenha dado seu quantum de contribuição para aprofundar e ampliar a compreensão desse fenômeno multifacetado do desenvolvimento humano, especialmente em suas conexões com a participação sociodigital. 


\section{Referências Bibliográficas:}

AGÊNCIA BRASIL. Não há democracia sem partido, diz ministro sobre reações antipartidárias. Disponível em: http://ultimosegundo.ig.com.br/politica/2013-06-21/naoha-democracia-sem-partido-diz-ministro-sobre-reacoes-antipartidarias.html. Acesso em: 27 out. 2015 .

ALKIRE, S.; DENEULIN, S. The Human Development and Capability Approach. Em: DENEULIN, S.; SHAHANI, L. (Eds.) An Introduction to the Human Development and Capability Approach: Freedom and Agency. London, Washington: Earthscan, 2009.

ALSOP, R.; HEINSOHN, N. Measuring Empowerment in Practice - Structuring Analysis and Framing Indicators. Washington D.C.: World Bank, 2005.

AVRITZER, L. Instituições participativas e desenho institucional: algumas considerações sobre a variação da participação no Brasil democrático. Campinas: OPINIÃO PÚBLICA, vol. 14, nº 1, Junho, p.43-64, 2008.

A Qualidade da democracia e a questão da efetividade da participação: mapeando o debate. Em: Pires, R. (Org.). Efetividade das instituições participativas no Brasil: estratégias de avaliação. Brasília: IPEA, Diálogos para o desenvolvimento, V. 7, p. 13-25, 2011.

COLEMAN, S.; BLUMLER, J. The Internet and Democratic Citizenship. New York: Cambridge University Press, 2009.

BHASKAR, R. A Realist Theory of Science. London: Routledge, 2008.

General introduction. In: M. Archer et al. (orgs.) Critical Realism. Essential readings. London; New York: Routledge, 1998. p. ix-xxiv.

CASTELLS, M. A Sociedade em Rede. São Paulo: Paz e Terra, 1999.

CASTELlS, E. Communication Power. New York: Oxford University Press, 2009. 
CNI. Agenda Legislativa da Indústria 2014. São Paulo: CNI, 2014. Agenda Legislativa da Indústria 2015. São Paulo: CNI, 2015.

DANERMARK, B.; EKSTRÖM, M.; JAKOBSEN, L.; KARLSSON, J. Explaining Society: Critical Realism in the Social Sciences. London: Routledge, 2002.

ELLUL, J. The Technological Society. New York: Vintage Books, 1964.

GOMES, W. Transformações da política na era da comunicação de massa. São Paulo: Paulus, 2004.

HEIDEGGER, M. The Question Concerning Technology. New York: Harper Torchbooks, 1977.

IBGE. Projeção da população do Brasil e das Unidades da Federação. Disponível em: http://www.ibge.gov.br/apps/populacao/projecao/. Acesso em: 27 out. 2015.

INGLEHART, Ronald. The Silent Revolution. Princeton: Princeton University Press, 1977.

Culture shift in advanced industrial society. Princeton: Princeton University Press, 1990.

Modernización y posmodernización: el cambio cultural, económico y político en 43 sociedades. Madrid: Centro de Investigaciones Sociológicas/Siglo Veintiuno, 2001.

INGLEHART, Ronald; WELZEL, Christian. Modernization, cultural change, and democracy: the human development sequence. New York: Cambridge University Press, 2005 .

IPEA. Análise e recomendações para as políticas públicas de massificação de acesso à internet em banda larga. Brasília: Comunicados do IPEA nº 46, 2010.

KELSEN, H. General Theory of Law and State. Cambridge: Harvard University Press, 1949. 
KLEINE, D. Technologies of Choice? ICTs, Development, and the Capability Approach. Cambridge. London: MIT Press, 2013.

LAVAlle, A. Participação: Valor, Utilidade, Efeitos e Causa. Em: Pires, R. (Org.). Efetividade das instituições participativas no Brasil: estratégias de avaliação. Brasília: IPEA, Diálogos para o desenvolvimento, V. 7, p. 33-42, 2011.

LEVY, P. Cyberculture. Minneapolis: University of Minnesota Press, 2001.

LONG, J. S.; FREESE, J. Regression models for categorical dependent variables. College Station, TX: Stata Press, 2001

MANCUSO, W.; FILHO, D. Financiamento empresarial nas campanhas para deputado federal no Brasil (2002-2010): determinantes e consequências. Caxambu: $38^{\circ}$ Encontro Anual Da Anpocs, 2014.

MANIN, Bernard; PRZEWORSKI, Adam; STOKES, Susan C. Introduction. Em:

(Ed.). Democracy, Accountability and Representation. 1. ed. Cambridge: Cambridge University Press, p. 1-26, 1999.

MARISCAL, J.; BOTELHO A. J. J; GUTIÉRREZ, L. H. A Capacitação em TIC's, Emprego e Jovens: $O$ caso do Brasil, Colômbia e México. Washington: CENTER FOR INFORMATION \& SOCIETY - University of Washington, 2008.

MAIA, R.; GOMES, W.; MARQUES, F. (orgs.) Internet e Participação Política no Brasil. Porto Alegre: Meridional/Sulina, 2011.

MARTINUSSEN, J. Society, State \& Market. London, New Jersey: Zed Books, 1997.

MASON, J. Qualitative researching. London: Sage, 2002.

Miguel, L. F. Política de Interesses, Política do Desvelo: Representação e “Singularidade Feminina". Santa Catarina: Estudos Feministas, p. 253-267, 2001.

Democracia e Representação: territórios em disputa. São Paulo: Editora Unesp, 2014. 
MONTERO, M. Teoría y práctica de la psicología comunitaria: la tensión entre comunidad y sociedad. Buenos Aires: Paidós, 2006.

NUSSBAUM, M. Creating Capabilities: The Human Development Approach. Cambridge, Massachusetts, London: Harvard University Press, 2011.

PAPADOPOULOS, Y.; WARIN, P. Are innovative, participatory, and deliberative procedures in policy making democratic and effective? European Journal of Political Research, v. 46, n. 4, p. 445-472, 2007.

PATEMAN, C. Participação e teoria democrática. Rio de Janeiro: Paz e Terra, 1992.

PITKIN, H. The Concept of Representation. Berkeley, Los Angeles, London: University of California Press, 1967.

PRZEWORSKI, A. Estado e Economia no Capitalismo. Rio de Janeiro: Dumará, 1995.

Democracy and the Limits of Self-Government. New York: Cambridge University Press, 2010.

ROBEYNS, I. The capability approach - A theoretical survey. Journal of Human Development, vol. 6, no. 1, pp. 93-114, 2005.

Sen's capability approach and feminist concerns. Em: ALKIRE, S., QIZILBASH, M. e COMIM, F. (org.). The Capability Approach: Concepts, Measures and Applications. Cambridge: Cambridge University Press, 2008.

ROSAnVAllon, P. Democratic Legitimacy: impartiality, Reflexivity, Proximity. New Jersey: Princeton University Press, 2011.

ROWE, G.; FREWER, L. Public Participation Methods: A Framework for Evaluation. Science, Technology, \& Human Values, Vol. 25, No. 1, p. 3-29, 2000.

SANTOS, M; SILVA, M.; FILHO, D.; ROCHA, E. Financiamento de campanha e apoio parlamentar à Agenda Legislativa da Indústria na Câmara dos Deputados. Campinas: Opinião Pública, vol. 21, nº 1, abril, p. 33-59, 2015. 
SAYER, A. Method in Social Science. New York; London: Routledge, 1992.

SCHULTZ, T. Mass Media and the Concept of Interactivity: An Exploratory Study of Online Forums and Reader Email. Bloomington: Media, Culture \& Society, 22(2), p. 205-222, 2000.

SEN, A. Freedom of choice: Concept and content. European Economic Review 32, p. 269-294, 1988.

. Inequality Re-Examined. Oxford: Clarendon Press, 1992.

Development as Freedom. New York: Anchor Books, 1999.

Rationality and Freedom. Cambridge: Harvard University Press, 2002.

The Idea of Justice. Cambridge: Harvard University Press, 2009.

SOUZA, Jessé. A construção social da subcidadania: para uma sociologia política da modernidade periférica. Belo Horizonte: Editora UFMG, 2003

UNDP. Human Development Report 1990. New York: Oxford University Press, 1990.

URBINATI, N. O que torna a representação democrática? São Paulo: Lua Nova, 67: 191-228, 2006.

Da democracia dos partidos ao plebiscite da audience. São Paulo: Lua Nova 89: 85-105, 2013.

. Democracy Disfigured: opinion, truth and the people. Cambridge: Harvard University Press, 2014.

TSE 2015. Estatísticas de eleitorado - Consulta Quantitativo. Disponível em: http://www.tse.jus.br/eleitor/estatisticas-de-eleitorado/consulta-quantitativo. Acesso em: 20/10/2015.

WOOD, E. M. Democracia contra Capitalismo. São Paulo: Boitempo, 2003. 
Estado, Democracia y Globalización. In: BARON, A.A; AMADEO, J.; GOZÁLES, S; (compiladores) La Teoría Marxista Hoy: problemas y perspectivas. Buenos Aires: Clacso Libros, 2006. 


\section{APÊNDICE I - TABELAS COM VOTOS DOS DEPUTADOS}

Tabela 20 - Votos nominais para a matéria M3

\begin{tabular}{|c|c|}
\hline Deputado (a) & Voto \\
\hline ABEL MESQUITA JR. & SIM \\
\hline ADAIL CARNEIRO & SIM \\
\hline ADALBERTO CAVALCANTI & $\langle-----\cdot->$ \\
\hline ADELMO CARNEIRO LEAO & $\mathrm{NAO}$ \\
\hline ADELSON BARRETO & SIM \\
\hline ADEMIR CAMILO & NAO \\
\hline ADILTON SACHETTI & SIM \\
\hline AELTON FREITAS & SIM \\
\hline AFONSO FLORENCE & NAO \\
\hline AFONSO HAMM & SIM \\
\hline AFONSO MOTTA & SIM \\
\hline AGUINALDO RIBEIRO & SIM \\
\hline ALAN RICK & SIM \\
\hline ALBERTO FRAGA & SIM \\
\hline ALCEU MOREIRA & SIM \\
\hline ALESSANDRO MOLON & NAO \\
\hline ALEX CANZIANI & SIM \\
\hline ALEX MANENTE & SIM \\
\hline ALEXANDRE BALDY & SIM \\
\hline ALEXANDRE LEITE & SIM \\
\hline ALEXANDRE SERFIOTIS & SIM \\
\hline ALEXANDRE VALLE & SIM \\
\hline ALFREDO KAEFER & SIM \\
\hline ALFREDO NASCIMENTO & SIM \\
\hline ALICE PORTUGAL & NAO \\
\hline ALIEL MACHADO & NAO \\
\hline ALTINEU CORTES & SIM \\
\hline ALUISIO MENDES & SIM \\
\hline ANA PERUGINI & NAO \\
\hline ANDERSON FERREIRA & SIM \\
\hline ANDRE ABDON & SIM \\
\hline ANDRE FIGUEIREDO & SIM \\
\hline ANDRE FUFUCA & SIM \\
\hline ANDRE MOURA & SIM \\
\hline ANDRES SANCHEZ & NAO \\
\hline ANGELIM & NAO \\
\hline ANIBAL GOMES & $\mid<------->$ \\
\hline ANTONIO BALHMANN & SIM \\
\hline ANTONIO BRITO & SIM \\
\hline ANTONIO BULHOES & NAO \\
\hline ANTONIO CARLOS MENDES THAME & <-------> \\
\hline ANTONIO IMBASSAHY & SIM \\
\hline
\end{tabular}




\begin{tabular}{|c|c|}
\hline ANTONIO JACOME & <-------> \\
\hline ARLINDO CHINAGLIA & NAO \\
\hline ARNALDO FARIA DE SA & NAO \\
\hline ARNALDO JORDY & NAO \\
\hline ARNON BEZERRA & SIM \\
\hline ARTHUR LIRA & SIM \\
\hline ARTHUR OLIVEIRA MAIA & SIM \\
\hline ARTHUR VIRGILIO BISNETO & SIM \\
\hline ASSIS CARVALHO & NAO \\
\hline ASSIS DO COUTO & NAO \\
\hline ATILA LINS & SIM \\
\hline ATILA LIRA & NAO \\
\hline AUGUSTO CARVALHO & SIM \\
\hline AUGUSTO COUTINHO & SIM \\
\hline AUREO & SIM \\
\hline BACELAR & NAO \\
\hline BALEIA ROSSI & SIM \\
\hline BEBETO & NAO \\
\hline BENEDITA DA SILVA & NAO \\
\hline BENITO GAMA & SIM \\
\hline BENJAMIN MARANHAO & SIM \\
\hline BETINHO GOMES & SIM \\
\hline BETO FARO & NAO \\
\hline BETO MANSUR & SIM \\
\hline BETO ROSADO & SIM \\
\hline BETO SALAME & NAO \\
\hline BILAC PINTO & SIM \\
\hline BOHN GASS & NAO \\
\hline BONIFACIO DE ANDRADA & <-------> \\
\hline BRUNA FURLAN & SIM \\
\hline BRUNNY & NAO \\
\hline BRUNO ARAUJO & $<------->$ \\
\hline BRUNO COVAS & SIM \\
\hline CABO DACIOLO & NAO \\
\hline CABO SABINO & NAO \\
\hline CABUCU BORGES & SIM \\
\hline CACA LEAO & SIM \\
\hline CAETANO & NAO \\
\hline CAIO NARCIO & SIM \\
\hline CAPITAO AUGUSTO & SIM \\
\hline CARLOS ANDRADE & SIM \\
\hline CARLOS BEZERRA & <-------> \\
\hline CARLOS EDUARDO CADOCA & SIM \\
\hline CARLOS GOMES & SIM \\
\hline CARLOS HENRIQUE GAGUIM & SIM \\
\hline CARLOS MANATO & SIM \\
\hline CARLOS MARUN & SIM \\
\hline CARLOS MELLES & SIM \\
\hline CARLOS SAMPAIO & $<-------\rangle$ \\
\hline CARLOS ZARATTINI & NAO \\
\hline
\end{tabular}




\begin{tabular}{|c|c|}
\hline CARMEN ZANOTTO & SIM \\
\hline CELIO SILVEIRA & SIM \\
\hline CELSO JACOB & SIM \\
\hline CELSO MALDANER & SIM \\
\hline CELSO PANSERA & SIM \\
\hline CELSO RUSSOMANNO & <-------> \\
\hline CESAR HALUM & SIM \\
\hline CESAR MESSIAS & $<------->$ \\
\hline CESAR SOUZA & SIM \\
\hline CHICO ALENCAR & NAO \\
\hline CHICO D ANGELO & NAO \\
\hline CHICO LOPES & $\mathrm{NAO}$ \\
\hline CHRISTIANE DE SOUZA YARED & NAO \\
\hline CICERO ALMEIDA & $<------>$ \\
\hline CLARISSA GAROTINHO & NAO \\
\hline CLAUDIO CAJADO & $<------>>$ \\
\hline CLEBER VERDE & SIM \\
\hline CONCEICAO SAMPAIO & SIM \\
\hline COVATTI FILHO & SIM \\
\hline CRISTIANE BRASIL & <-------> \\
\hline DAGOBERTO & SIM \\
\hline DAMIAO FELICIANO & $\mathrm{NAO}$ \\
\hline DAMINA PEREIRA & SIM \\
\hline DANIEL ALMEIDA & $\mathrm{NAO}$ \\
\hline DANIEL COELHO & SIM \\
\hline DANIEL VILELA & SIM \\
\hline DANILO FORTE & SIM \\
\hline DANRLEI DE DEUS HINTERHOLZ & NAO \\
\hline DARCISIO PERONDI & SIM \\
\hline DAVIDSON MAGALHAES & NAO \\
\hline DECIO LIMA & NAO \\
\hline DELEGADO EDER MAURO & ABSTENCAO \\
\hline DELEGADO EDSON MOREIRA & SIM \\
\hline DELEGADO WALDIR & SIM \\
\hline DELEY & NAO \\
\hline DEOCLIDES MACEDO & SIM \\
\hline DIEGO ANDRADE & SIM \\
\hline DIEGO GARCIA & NAO \\
\hline DILCEU SPERAFICO & SIM \\
\hline DIMAS FABIANO & SIM \\
\hline DOMINGOS NETO & SIM \\
\hline DOMINGOS SAVIO & SIM \\
\hline DR. JOAO & SIM \\
\hline DR. JORGE SILVA & SIM \\
\hline DR. SINVAL MALHEIROS & $<------->$ \\
\hline DULCE MIRANDA & SIM \\
\hline EDINHO BEZ & SIM \\
\hline EDIO LOPES & SIM \\
\hline EDMAR ARRUDA & $<------>$ \\
\hline EDMILSON RODRIGUES & NAO \\
\hline
\end{tabular}




\begin{tabular}{|c|c|}
\hline EDUARDO BARBOSA & SIM \\
\hline EDUARDO BOLSONARO & <------>> \\
\hline EDUARDO CUNHA & ART. 17 \\
\hline EDUARDO CURY & SIM \\
\hline EDUARDO DA FONTE & SIM \\
\hline EFRAIM FILHO & SIM \\
\hline ELCIONE BARBALHO & SIM \\
\hline ELI CORREA FILHO & SIM \\
\hline ELIZEU DIONIZIO & SIM \\
\hline ELIZIANE GAMA & NAO \\
\hline ELMAR NASCIMENTO & SIM \\
\hline ENIO VERRI & $\mathrm{NAO}$ \\
\hline ERIKA KOKAY & $\mathrm{NAO}$ \\
\hline ERIVELTON SANTANA & SIM \\
\hline EROS BIONDINI & NAO \\
\hline ESPERIDIAO AMIN & SIM \\
\hline EVAIR DE MELO & SIM \\
\hline EVANDRO GUSSI & SIM \\
\hline EVANDRO ROGERIO ROMAN & SIM \\
\hline EXPEDITO NETTO & SIM \\
\hline EZEQUIEL FONSECA & SIM \\
\hline EZEQUIEL TEIXEIRA & SIM \\
\hline FABIANO HORTA & NAO \\
\hline FABIO FARIA & SIM \\
\hline FABIO GARCIA & SIM \\
\hline FABIO MITIDIERI & SIM \\
\hline FABIO RAMALHO & SIM \\
\hline FABIO REIS & SIM \\
\hline FABIO SOUSA & SIM \\
\hline FAUSTO PINATO & SIM \\
\hline FELIPE BORNIER & $<------->$ \\
\hline FELIPE MAIA & SIM \\
\hline FELIX MENDONCA JUNIOR & SIM \\
\hline FERNANDO COELHO FILHO & SIM \\
\hline FERNANDO JORDAO & SIM \\
\hline FERNANDO MARRONI & NAO \\
\hline FERNANDO MONTEIRO & SIM \\
\hline FERNANDO TORRES & SIM \\
\hline FLAVIA MORAIS & SIM \\
\hline FLAVIANO MELO & SIM \\
\hline FLAVINHO & SIM \\
\hline FRANCISCO CHAPADINHA & SIM \\
\hline FRANCISCO FLORIANO & SIM \\
\hline GABRIEL GUIMARAES & $<------->$ \\
\hline GENECIAS NORONHA & SIM \\
\hline GEOVANIA DE SA & $\mathrm{NAO}$ \\
\hline GERALDO RESENDE & SIM \\
\hline GIACOBO & SIM \\
\hline GILBERTO NASCIMENTO & SIM \\
\hline GIOVANI CHERINI & SIM \\
\hline
\end{tabular}




\begin{tabular}{|c|c|}
\hline GIUSEPPE VECCI & SIM \\
\hline GIVALDO CARIMBAO & SIM \\
\hline GIVALDO VIEIRA & NAO \\
\hline GLAUBER BRAGA & $\mathrm{NAO}$ \\
\hline GONZAGA PATRIOTA & SIM \\
\hline GORETE PEREIRA & SIM \\
\hline GOULART & SIM \\
\hline GUILHERME MUSSI & SIM \\
\hline HEITOR SCHUCH & NAO \\
\hline HELDER SALOMAO & NAO \\
\hline HELIO LEITE & SIM \\
\hline HENRIQUE FONTANA & $\mathrm{NAO}$ \\
\hline HERACLITO FORTES & SIM \\
\hline HERCULANO PASSOS & SIM \\
\hline HERMES PARCIANELLO & $\mathrm{NAO}$ \\
\hline HEULER CRUVINEL & SIM \\
\hline HILDO ROCHA & SIM \\
\hline HIRAN GONCALVES & SIM \\
\hline HISSA ABRAHAO & SIM \\
\hline HUGO LEAL & SIM \\
\hline HUGO MOTTA & SIM \\
\hline INDIO DA COSTA & $<------->$ \\
\hline IRACEMA PORTELLA & SIM \\
\hline IRAJA ABREU & SIM \\
\hline IRMAO LAZARO & SIM \\
\hline IVAN VALENTE & NAO \\
\hline IZALCI & SIM \\
\hline JAIME MARTINS & SIM \\
\hline JAIR BOLSONARO & $<------->$ \\
\hline JANDIRA FEGHALI & NAO \\
\hline JANETE CAPIBERIBE & NAO \\
\hline JARBAS VASCONCELOS & SIM \\
\hline JEAN WYLLYS & NAO \\
\hline JEFFERSON CAMPOS & SIM \\
\hline JERONIMO GOERGEN & SIM \\
\hline JESSICA SALES & $\mid<------->$ \\
\hline $\mathrm{JHC}$ & $\langle------>>$ \\
\hline JHONATAN DE JESUS & SIM \\
\hline JO MORAES & NAO \\
\hline JOAO ARRUDA & NAO \\
\hline JOAO CAMPOS & SIM \\
\hline JOAO CARLOS BACELAR & NAO \\
\hline JOAO CASTELO & SIM \\
\hline JOAO DANIEL & NAO \\
\hline JOAO DERLY & NAO \\
\hline JOAO FERNANDO COUTINHO & SIM \\
\hline JOAO GUALBERTO & SIM \\
\hline JOAO MARCELO SOUZA & SIM \\
\hline JOAO PAULO PAPA & SIM \\
\hline JOAO RODRIGUES & SIM \\
\hline
\end{tabular}




\begin{tabular}{|c|c|}
\hline JOAQUIM PASSARINHO & SIM \\
\hline JONY MARCOS & $\mathrm{NAO}$ \\
\hline JORGE BOEIRA & NAO \\
\hline JORGE CORTE REAL & SIM \\
\hline JORGE SOLLA & NAO \\
\hline JORGE TADEU MUDALEN & SIM \\
\hline JORGINHO MELLO & SIM \\
\hline JOSE AIRTON CIRILO & NAO \\
\hline JOSE CARLOS ALELUIA & SIM \\
\hline JOSE CARLOS ARAUJO & SIM \\
\hline JOSE FOGACA & SIM \\
\hline JOSE GUIMARAES & $\mathrm{NAO}$ \\
\hline JOSE MENTOR & NAO \\
\hline JOSE NUNES & SIM \\
\hline JOSE OTAVIO GERMANO & SIM \\
\hline JOSE PRIANTE & $\mid<------>$ \\
\hline JOSE REINALDO & SIM \\
\hline JOSE ROCHA & SIM \\
\hline JOSE STEDILE & $\mathrm{NAO}$ \\
\hline JOSI NUNES & SIM \\
\hline JOSUE BENGTSON & SIM \\
\hline JOVAIR ARANTES & SIM \\
\hline JOZI ROCHA & SIM \\
\hline JULIA MARINHO & SIM \\
\hline JULIO CESAR & SIM \\
\hline JULIO DELGADO & SIM \\
\hline JULIO LOPES & SIM \\
\hline JUNIOR MARRECA & SIM \\
\hline JUSCELINO FILHO & SIM \\
\hline JUTAHY JUNIOR & $\mid<------->$ \\
\hline KAIO MANICOBA & SIM \\
\hline KEIKO OTA & SIM \\
\hline LAERCIO OLIVEIRA & SIM \\
\hline LAERTE BESSA & $\mid<-----\cdot>$ \\
\hline LAUDIVIO CARVALHO & SIM \\
\hline LAZARO BOTELHO & SIM \\
\hline LEANDRE & SIM \\
\hline LELO COIMBRA & SIM \\
\hline LEO DE BRITO & NAO \\
\hline LEONARDO MONTEIRO & NAO \\
\hline LEONARDO PICCIANI & SIM \\
\hline LEONARDO QUINTAO & SIM \\
\hline LEONIDAS CRISTINO & SIM \\
\hline LEOPOLDO MEYER & SIM \\
\hline LINCOLN PORTELA & NAO \\
\hline LINDOMAR GARCON & SIM \\
\hline LOBBE NETO & SIM \\
\hline LUCAS VERGILIO & SIM \\
\hline LUCIANA SANTOS & $\mathrm{NAO}$ \\
\hline LUCIANO DUCCI & SIM \\
\hline
\end{tabular}




\begin{tabular}{|c|c|}
\hline LUCIO MOSQUINI & NAO \\
\hline LUCIO VALE & $|<------\rangle$ \\
\hline LUCIO VIEIRA LIMA & SIM \\
\hline LUIS CARLOS HEINZE & SIM \\
\hline LUIS TIBE & SIM \\
\hline LUIZ CARLOS BUSATO & SIM \\
\hline LUIZ CARLOS HAULY & SIM \\
\hline LUIZ CARLOS RAMOS & SIM \\
\hline LUIZ CLAUDIO & SIM \\
\hline LUIZ COUTO & NAO \\
\hline LUIZ FERNANDO FARIA & SIM \\
\hline LUIZ LAURO FILHO & SIM \\
\hline LUIZ NISHIMORI & SIM \\
\hline LUIZ SERGIO & NAO \\
\hline LUIZA ERUNDINA & NAO \\
\hline LUIZIANNE LINS & NAO \\
\hline MACEDO & NAO \\
\hline MAGDA MOFATTO & SIM \\
\hline MAJOR OLIMPIO & SIM \\
\hline MANDETTA & SIM \\
\hline MANOEL JUNIOR & SIM \\
\hline MARA GABRILLI & NAO \\
\hline MARCELO AGUIAR & $\langle<----\cdot->$ \\
\hline MARCELO ALVARO ANTONIO & SIM \\
\hline MARCELO ARO & SIM \\
\hline MARCELO BELINATI & NAO \\
\hline MARCELO CASTRO & SIM \\
\hline MARCELO MATOS & NAO \\
\hline MARCELO SQUASSONI & SIM \\
\hline MARCIO ALVINO & SIM \\
\hline MARCIO MARINHO & NAO \\
\hline MARCO MAIA & NAO \\
\hline MARCO TEBALDI & SIM \\
\hline MARCON & NAO \\
\hline MARCOS ABRAO & SIM \\
\hline MARCOS MONTES & SIM \\
\hline MARCOS REATEGUI & NAO \\
\hline MARCOS ROGERIO & NAO \\
\hline MARCOS ROTTA & SIM \\
\hline MARCOS SOARES & <-------> \\
\hline MARCUS PESTANA & SIM \\
\hline MARCUS VICENTE & SIM \\
\hline MARGARIDA SALOMAO & NAO \\
\hline MARIA DO ROSARIO & NAO \\
\hline MARIA HELENA & NAO \\
\hline MARIANA CARVALHO & SIM \\
\hline MARINALDO ROSENDO & SIM \\
\hline MARINHA RAUPP & NAO \\
\hline MARIO HERINGER & SIM \\
\hline MARIO NEGROMONTE JR. & SIM \\
\hline
\end{tabular}




\begin{tabular}{|c|c|}
\hline MARQUINHO MENDES & SIM \\
\hline MARX BELTRAO & SIM \\
\hline MAURICIO QUINTELLA LESSA & SIM \\
\hline MAURO LOPES & SIM \\
\hline MAURO MARIANI & SIM \\
\hline MAURO PEREIRA & SIM \\
\hline MAX FILHO & $\mid<------>$ \\
\hline MENDONCA FILHO & $<------>$ \\
\hline MERLONG SOLANO & NAO \\
\hline MIGUEL HADDAD & SIM \\
\hline MIGUEL LOMBARDI & SIM \\
\hline MILTON MONTI & SIM \\
\hline MIRO TEIXEIRA & NAO \\
\hline MISAEL VARELLA & SIM \\
\hline MISSIONARIO JOSE OLIMPIO & SIM \\
\hline MOEMA GRAMACHO & NAO \\
\hline MORONI TORGAN & NAO \\
\hline MOSES RODRIGUES & NAO \\
\hline NELSON MARCHEZAN JUNIOR & SIM \\
\hline NELSON MARQUEZELLI & SIM \\
\hline NELSON MEURER & NAO \\
\hline NEWTON CARDOSO JR & SIM \\
\hline NILSON LEITAO & SIM \\
\hline NILSON PINTO & SIM \\
\hline NILTO TATTO & NAO \\
\hline NILTON CAPIXABA & SIM \\
\hline ODELMO LEAO & SIM \\
\hline ODORICO MONTEIRO & NAO \\
\hline ONYX LORENZONI & SIM \\
\hline ORLANDO SILVA & NAO \\
\hline OSMAR BERTOLDI & SIM \\
\hline OSMAR SERRAGLIO & SIM \\
\hline OSMAR TERRA & NAO \\
\hline OTAVIO LEITE & SIM \\
\hline PADRE JOAO & NAO \\
\hline PAES LANDIM & SIM \\
\hline PASTOR EURICO & SIM \\
\hline PASTOR FRANKLIN & SIM \\
\hline PAUDERNEY AVELINO & SIM \\
\hline PAULAO & NAO \\
\hline PAULO ABI-ACKEL & SIM \\
\hline PAULO AZI & SIM \\
\hline PAULO FEIJO & SIM \\
\hline PAULO FOLETTO & SIM \\
\hline PAULO FREIRE & <-------> \\
\hline PAULO MAGALHAES & $<------->$ \\
\hline PAULO MALUF & SIM \\
\hline PAULO PEREIRA DA SILVA & SIM \\
\hline PAULO PIMENTA & NAO \\
\hline PAULO TEIXEIRA & NAO \\
\hline
\end{tabular}




\begin{tabular}{|c|c|}
\hline PEDRO CHAVES & SIM \\
\hline PEDRO CUNHA LIMA & SIM \\
\hline PEDRO FERNANDES & $\mathrm{NAO}$ \\
\hline PEDRO UCZAI & NAO \\
\hline PEDRO VILELA & SIM \\
\hline POMPEO DE MATTOS & <-------> \\
\hline PR. MARCO FELICIANO & $\mathrm{NAO}$ \\
\hline PROFESSOR VICTORIO GALLI & SIM \\
\hline $\begin{array}{l}\text { PROFESSORA DORINHA SEABRA } \\
\text { REZEN }\end{array}$ & NAO \\
\hline PROFESSORA MARCIVANIA & $\mathrm{NAO}$ \\
\hline RAFAEL MOTTA & $\mid<------>>$ \\
\hline RAIMUNDO GOMES DE MATOS & SIM \\
\hline RAQUEL MUNIZ & SIM \\
\hline RAUL JUNGMANN & SIM \\
\hline REGINALDO LOPES & <-------> \\
\hline REMIDIO MONAI & SIM \\
\hline RENATA ABREU & SIM \\
\hline RENATO MOLLING & SIM \\
\hline RENZO BRAZ & $|<-------\rangle$ \\
\hline RICARDO BARROS & SIM \\
\hline RICARDO IZAR & SIM \\
\hline RICARDO TEOBALDO & SIM \\
\hline RICARDO TRIPOLI & SIM \\
\hline ROBERTO ALVES & $\langle------->$ \\
\hline ROBERTO BALESTRA & SIM \\
\hline ROBERTO BRITTO & SIM \\
\hline ROBERTO FREIRE & SIM \\
\hline ROBERTO GOES & SIM \\
\hline ROBERTO SALES & SIM \\
\hline $\mathrm{ROCHA}$ & SIM \\
\hline RODRIGO DE CASTRO & SIM \\
\hline RODRIGO MAIA & SIM \\
\hline RODRIGO MARTINS & SIM \\
\hline RODRIGO PACHECO & SIM \\
\hline ROGERIO MARINHO & SIM \\
\hline ROGERIO PENINHA MENDONCA & SIM \\
\hline ROGERIO ROSSO & SIM \\
\hline ROMULO GOUVEIA & SIM \\
\hline RONALDO BENEDET & SIM \\
\hline RONALDO CARLETTO & SIM \\
\hline RONALDO FONSECA & SIM \\
\hline RONALDO LESSA & $<-------\rangle$ \\
\hline RONALDO MARTINS & $\mathrm{NAO}$ \\
\hline RONALDO NOGUEIRA & NAO \\
\hline RONEY NEMER & SIM \\
\hline ROSANGELA GOMES & SIM \\
\hline ROSSONI & SIM \\
\hline RUBENS BUENO & SIM \\
\hline RUBENS OTONI & $\mid<------->$ \\
\hline
\end{tabular}




\begin{tabular}{|c|c|}
\hline RUBENS PEREIRA JUNIOR & NAO \\
\hline SAGUAS MORAES & $\mathrm{NAO}$ \\
\hline SAMUEL MOREIRA & SIM \\
\hline SANDES JUNIOR & SIM \\
\hline SANDRO ALEX & SIM \\
\hline SARAIVA FELIPE & SIM \\
\hline SARNEY FILHO & $<------>>$ \\
\hline SERGIO BRITO & SIM \\
\hline SERGIO MORAES & <-------> \\
\hline SERGIO REIS & <----->> \\
\hline SERGIO SOUZA & SIM \\
\hline SERGIO VIDIGAL & SIM \\
\hline SERGIO ZVEITER & SIM \\
\hline SHERIDAN & SIM \\
\hline SIBA MACHADO & $\mathrm{NAO}$ \\
\hline SILAS BRASILEIRO & SIM \\
\hline SILAS CAMARA & <------> \\
\hline SILAS FREIRE & $\mathrm{NAO}$ \\
\hline SILVIO COSTA & SIM \\
\hline SILVIO TORRES & SIM \\
\hline SIMAO SESSIM & SIM \\
\hline SIMONE MORGADO & $<-----\cdot>$ \\
\hline SORAYA SANTOS & SIM \\
\hline SOSTENES CAVALCANTE & $\mathrm{NAO}$ \\
\hline STEFANO AGUIAR & SIM \\
\hline SUBTENENTE GONZAGA & NAO \\
\hline TADEU ALENCAR & $\mathrm{NAO}$ \\
\hline TAKAYAMA & $<------->$ \\
\hline TENENTE LUCIO & SIM \\
\hline TEREZA CRISTINA & SIM \\
\hline TIA ERON & SIM \\
\hline TIRIRICA & $\mathrm{NAO}$ \\
\hline TONINHO PINHEIRO & SIM \\
\hline TONINHO WANDSCHEER & $\mathrm{NAO}$ \\
\hline ULDURICO JUNIOR & NAO \\
\hline VALADARES FILHO & $\langle------->$ \\
\hline VALDIR COLATTO & SIM \\
\hline VALMIR ASSUNCAO & NAO \\
\hline VALMIR PRASCIDELLI & $\mathrm{NAO}$ \\
\hline VALTENIR PEREIRA & SIM \\
\hline VANDER LOUBET & NAO \\
\hline VANDERLEI MACRIS & <-------> \\
\hline VENEZIANO VITAL DO REGO & SIM \\
\hline VICENTE CANDIDO & NAO \\
\hline VICENTINHO & NAO \\
\hline VICENTINHO JUNIOR & SIM \\
\hline VICTOR MENDES & SIM \\
\hline VINICIUS CARVALHO & SIM \\
\hline VINICIUS GURGEL & SIM \\
\hline VITOR LIPPI & SIM \\
\hline
\end{tabular}




\begin{tabular}{|l|c|} 
VITOR VALIM & NAO \\
\hline WADSON RIBEIRO & NAO \\
\hline WALDENOR PEREIRA & NAO \\
\hline WALDIR MARANHAO & $<----->$ \\
\hline WALNEY ROCHA & SIM \\
\hline WALTER ALVES & SIM \\
\hline WALTER IHOSHI & SIM \\
\hline WASHINGTON REIS & SIM \\
\hline WELITON PRADO & NAO \\
\hline WELLINGTON ROBERTO & SIM \\
\hline WEVERTON ROCHA & SIM \\
\hline WILLIAM WOO & SIM \\
\hline WILSON FILHO & SIM \\
\hline WLADIMIR COSTA & $<------>$ \\
\hline WOLNEY QUEIROZ & NAO \\
\hline ZE CARLOS & NAO \\
\hline ZE GERALDO & NAO \\
\hline ZE SILVA & SIM \\
\hline ZECA CAVALCANTI & NAO \\
\hline ZECA DIRCEU & NAO \\
\hline ZECA DO PT & NAO \\
\hline ZENAIDE MAIA & ABSTENCAO \\
\hline
\end{tabular}

<------> = ausente

Fonte: elaboração própria, a partir dos dados de votação disponibilizados pela Câmara dos Deputados.

Tabela 21 - Votos nominais para a matéria M4

\begin{tabular}{|l|c|}
\hline \multicolumn{1}{|c|}{ Deputado (a) } & Voto \\
\hline ABEL MESQUITA JR. & NAO \\
\hline ADAIL CARNEIRO & SIM \\
\hline ADALBERTO CAVALCANTI & $<----->$ \\
\hline ADELMO CARNEIRO LEAO & SIM \\
\hline ADELSON BARRETO & NAO \\
\hline ADEMIR CAMILO & $<----->$ \\
\hline ADILTON SACHETTI & SIM \\
\hline AELTON FREITAS & SIM \\
\hline AFONSO FLORENCE & SIM \\
\hline AFONSO HAMM & NAO \\
\hline AFONSO MOTTA & NAO \\
\hline AGUINALDO RIBEIRO & SIM \\
\hline ALAN RICK & SIM \\
\hline ALBERTO FILHO & SIM \\
\hline ALBERTO FRAGA & NAO \\
\hline ALCEU MOREIRA & SIM \\
\hline
\end{tabular}




\begin{tabular}{|c|c|}
\hline ALESSANDRO MOLON & SIM \\
\hline ALEX CANZIANI & SIM \\
\hline ALEX MANENTE & NAO \\
\hline ALEXANDRE BALDY & $\mathrm{NAO}$ \\
\hline ALEXANDRE LEITE & NAO \\
\hline ALEXANDRE SERFIOTIS & SIM \\
\hline ALEXANDRE VALLE & SIM \\
\hline ALFREDO KAEFER & NAO \\
\hline ALFREDO NASCIMENTO & SIM \\
\hline ALICE PORTUGAL & <----->> \\
\hline ALIEL MACHADO & SIM \\
\hline ALTINEU CORTES & SIM \\
\hline ALUISIO MENDES & SIM \\
\hline ANA PERUGINI & SIM \\
\hline ANDERSON FERREIRA & SIM \\
\hline ANDRE ABDON & SIM \\
\hline ANDRE FIGUEIREDO & $\mathrm{NAO}$ \\
\hline ANDRE FUFUCA & SIM \\
\hline ANDRE MOURA & $<------->$ \\
\hline ANDRES SANCHEZ & SIM \\
\hline ANGELIM & SIM \\
\hline ANIBAL GOMES & SIM \\
\hline ANTONIO BALHMANN & SIM \\
\hline ANTONIO BRITO & $\mathrm{NAO}$ \\
\hline ANTONIO BULHOES & SIM \\
\hline ANTONIO CARLOS MENDES THAME & $\langle------->$ \\
\hline ANTONIO IMBASSAHY & NAO \\
\hline ANTONIO JACOME & NAO \\
\hline ARLINDO CHINAGLIA & SIM \\
\hline ARNALDO FARIA DE SA & NAO \\
\hline ARNALDO JORDY & NAO \\
\hline ARNON BEZERRA & SIM \\
\hline ARTHUR LIRA & SIM \\
\hline ARTHUR OLIVEIRA MAIA & $\mathrm{NAO}$ \\
\hline ARTHUR VIRGILIO BISNETO & $\mathrm{NAO}$ \\
\hline ASSIS CARVALHO & SIM \\
\hline ASSIS DO COUTO & SIM \\
\hline ATILA LINS & SIM \\
\hline ATILA LIRA & SIM \\
\hline AUGUSTO CARVALHO & NAO \\
\hline AUGUSTO COUTINHO & $\mathrm{NAO}$ \\
\hline AUREO & $\mathrm{NAO}$ \\
\hline BACELAR & SIM \\
\hline BALEIA ROSSI & SIM \\
\hline BEBETO & $\mathrm{NAO}$ \\
\hline BENEDITA DA SILVA & SIM \\
\hline BENITO GAMA & NAO \\
\hline BENJAMIN MARANHAO & NAO \\
\hline BETINHO GOMES & NAO \\
\hline BETO FARO & SIM \\
\hline
\end{tabular}




\begin{tabular}{|c|c|}
\hline BETO MANSUR & $<------>$ \\
\hline BETO ROSADO & $<------>>$ \\
\hline BETO SALAME & SIM \\
\hline BILAC PINTO & SIM \\
\hline BOHN GASS & SIM \\
\hline BONIFACIO DE ANDRADA & <-------> \\
\hline BRUNA FURLAN & $<------>>$ \\
\hline BRUNNY & SIM \\
\hline BRUNO ARAUJO & $<------>>$ \\
\hline BRUNO COVAS & NAO \\
\hline CABO DACIOLO & NAO \\
\hline CABO SABINO & SIM \\
\hline CABUCU BORGES & SIM \\
\hline CACA LEAO & SIM \\
\hline CAETANO & SIM \\
\hline CAIO NARCIO & NAO \\
\hline CAPITAO AUGUSTO & SIM \\
\hline CARLOS ANDRADE & SIM \\
\hline CARLOS BEZERRA & SIM \\
\hline CARLOS EDUARDO CADOCA & SIM \\
\hline CARLOS GOMES & SIM \\
\hline CARLOS HENRIQUE GAGUIM & SIM \\
\hline CARLOS MANATO & NAO \\
\hline CARLOS MARUN & SIM \\
\hline CARLOS MELLES & $\mid<------>$ \\
\hline CARLOS SAMPAIO & NAO \\
\hline CARLOS ZARATTINI & SIM \\
\hline CARMEN ZANOTTO & NAO \\
\hline CELIO SILVEIRA & $\mathrm{NAO}$ \\
\hline CELSO JACOB & SIM \\
\hline CELSO MALDANER & SIM \\
\hline CELSO PANSERA & SIM \\
\hline CELSO RUSSOMANNO & SIM \\
\hline CESAR HALUM & SIM \\
\hline CESAR MESSIAS & NAO \\
\hline CESAR SOUZA & $\mid<------>$ \\
\hline CHICO ALENCAR & NAO \\
\hline CHICO D ANGELO & SIM \\
\hline CHICO LOPES & SIM \\
\hline CHRISTIANE DE SOUZA YARED & NAO \\
\hline CICERO ALMEIDA & NAO \\
\hline CLARISSA GAROTINHO & SIM \\
\hline CLAUDIO CAJADO & SIM \\
\hline CLEBER VERDE & SIM \\
\hline CONCEICAO SAMPAIO & $\mathrm{NAO}$ \\
\hline COVATTI FILHO & SIM \\
\hline CRISTIANE BRASIL & NAO \\
\hline DAGOBERTO & NAO \\
\hline DAMIAO FELICIANO & NAO \\
\hline DAMINA PEREIRA & SIM \\
\hline
\end{tabular}




\begin{tabular}{|c|c|}
\hline DANIEL ALMEIDA & SIM \\
\hline DANIEL COELHO & $\mathrm{NAO}$ \\
\hline DANIEL VILELA & SIM \\
\hline DANILO FORTE & SIM \\
\hline DANRLEI DE DEUS HINTERHOLZ & SIM \\
\hline DARCISIO PERONDI & SIM \\
\hline DAVIDSON MAGALHAES & SIM \\
\hline DECIO LIMA & <------>> \\
\hline DELEGADO EDER MAURO & NAO \\
\hline DELEGADO EDSON MOREIRA & SIM \\
\hline DELEGADO WALDIR & NAO \\
\hline DELEY & $\mathrm{NAO}$ \\
\hline DIEGO ANDRADE & SIM \\
\hline DIEGO GARCIA & SIM \\
\hline DILCEU SPERAFICO & SIM \\
\hline DIMAS FABIANO & SIM \\
\hline DOMINGOS NETO & SIM \\
\hline DOMINGOS SAVIO & $\mathrm{NAO}$ \\
\hline DR. JOAO & SIM \\
\hline DR. JORGE SILVA & SIM \\
\hline DR. SINVAL MALHEIROS & NAO \\
\hline DULCE MIRANDA & SIM \\
\hline EDINHO BEZ & ABSTENCAO \\
\hline EDIO LOPES & SIM \\
\hline EDMAR ARRUDA & $\mathrm{NAO}$ \\
\hline EDMILSON RODRIGUES & NAO \\
\hline EDUARDO BARBOSA & $\mathrm{NAO}$ \\
\hline EDUARDO BOLSONARO & NAO \\
\hline EDUARDO CUNHA & ART. 17 \\
\hline EDUARDO CURY & NAO \\
\hline EDUARDO DA FONTE & SIM \\
\hline EFRAIM FILHO & $\mathrm{NAO}$ \\
\hline ELCIONE BARBALHO & SIM \\
\hline ELI CORREA FILHO & $\mathrm{NAO}$ \\
\hline ELIZEU DIONIZIO & SIM \\
\hline ELIZIANE GAMA & NAO \\
\hline ELMAR NASCIMENTO & $<<----\cdot->$ \\
\hline ENIO VERRI & SIM \\
\hline ERIKA KOKAY & <------>> \\
\hline ERIVELTON SANTANA & NAO \\
\hline EROS BIONDINI & $\mathrm{NAO}$ \\
\hline ESPERIDIAO AMIN & $\mathrm{NAO}$ \\
\hline EVAIR DE MELO & SIM \\
\hline EVANDRO GUSSI & NAO \\
\hline EVANDRO ROMAN & SIM \\
\hline EXPEDITO NETTO & $\mathrm{NAO}$ \\
\hline EZEQUIEL FONSECA & SIM \\
\hline EZEQUIEL TEIXEIRA & NAO \\
\hline FABIANO HORTA & SIM \\
\hline FABIO FARIA & SIM \\
\hline
\end{tabular}




\begin{tabular}{|c|c|}
\hline FABIO GARCIA & SIM \\
\hline FABIO MITIDIERI & SIM \\
\hline FABIO RAMALHO & $<------>$ \\
\hline FABIO REIS & SIM \\
\hline FABIO SOUSA & NAO \\
\hline FAUSTO PINATO & SIM \\
\hline FELIPE BORNIER & $\mathrm{NAO}$ \\
\hline FELIPE MAIA & NAO \\
\hline FELIX MENDONCA JUNIOR & NAO \\
\hline FERNANDO COELHO FILHO & SIM \\
\hline FERNANDO JORDAO & SIM \\
\hline FERNANDO MARRONI & SIM \\
\hline FERNANDO MONTEIRO & $\mid<------>$ \\
\hline FERNANDO TORRES & SIM \\
\hline FLAVIA MORAIS & $\mathrm{NAO}$ \\
\hline FLAVIANO MELO & SIM \\
\hline FLAVINHO & $\mathrm{NAO}$ \\
\hline FRANCISCO CHAPADINHA & <-------> \\
\hline FRANCISCO FLORIANO & SIM \\
\hline GABRIEL GUIMARAES & SIM \\
\hline GENECIAS NORONHA & NAO \\
\hline GEOVANIA DE SA & $\mathrm{NAO}$ \\
\hline GERALDO RESENDE & $\mid<------>>$ \\
\hline GIACOBO & SIM \\
\hline GILBERTO NASCIMENTO & $\mathrm{NAO}$ \\
\hline GIOVANI CHERINI & NAO \\
\hline GIUSEPPE VECCI & $\mathrm{NAO}$ \\
\hline GIVALDO CARIMBAO & SIM \\
\hline GIVALDO VIEIRA & SIM \\
\hline GLAUBER BRAGA & $\mathrm{NAO}$ \\
\hline GONZAGA PATRIOTA & NAO \\
\hline GORETE PEREIRA & SIM \\
\hline GOULART & $<------->$ \\
\hline GUILHERME MUSSI & SIM \\
\hline HEITOR SCHUCH & $\mathrm{NAO}$ \\
\hline HELDER SALOMAO & SIM \\
\hline HELIO LEITE & $\mathrm{NAO}$ \\
\hline HENRIQUE FONTANA & SIM \\
\hline HERACLITO FORTES & $<------->$ \\
\hline HERCULANO PASSOS & SIM \\
\hline HERMES PARCIANELLO & $\mathrm{NAO}$ \\
\hline HEULER CRUVINEL & SIM \\
\hline HILDO ROCHA & $\langle------>>$ \\
\hline HIRAN GONCALVES & SIM \\
\hline HISSA ABRAHAO & $<------->$ \\
\hline HUGO LEAL & SIM \\
\hline HUGO MOTTA & $<------->$ \\
\hline INDIO DA COSTA & $<------->$ \\
\hline IRACEMA PORTELLA & SIM \\
\hline IRAJA ABREU & SIM \\
\hline
\end{tabular}




\begin{tabular}{|c|c|}
\hline IRMAO LAZARO & NAO \\
\hline IVAN VALENTE & $\mathrm{NAO}$ \\
\hline IZALCI & NAO \\
\hline JAIME MARTINS & SIM \\
\hline JAIR BOLSONARO & NAO \\
\hline JANDIRA FEGHALI & SIM \\
\hline JANETE CAPIBERIBE & <-------> \\
\hline JARBAS VASCONCELOS & NAO \\
\hline JEAN WYLLYS & NAO \\
\hline JEFFERSON CAMPOS & NAO \\
\hline JERONIMO GOERGEN & $\mathrm{NAO}$ \\
\hline JESSICA SALES & SIM \\
\hline $\mathrm{JHC}$ & $\mathrm{NAO}$ \\
\hline JHONATAN DE JESUS & $<------>$ \\
\hline JO MORAES & SIM \\
\hline JOAO ARRUDA & <------> \\
\hline JOAO CAMPOS & $\mathrm{NAO}$ \\
\hline JOAO CARLOS BACELAR & SIM \\
\hline JOAO CASTELO & NAO \\
\hline JOAO DANIEL & SIM \\
\hline JOAO DERLY & SIM \\
\hline JOAO FERNANDO COUTINHO & SIM \\
\hline JOAO GUALBERTO & $\mathrm{NAO}$ \\
\hline JOAO MARCELO SOUZA & SIM \\
\hline JOAO PAULO PAPA & $\mathrm{NAO}$ \\
\hline JOAO RODRIGUES & NAO \\
\hline JOAQUIM PASSARINHO & $\mathrm{NAO}$ \\
\hline JONY MARCOS & SIM \\
\hline JORGE BOEIRA & NAO \\
\hline JORGE CORTE REAL & SIM \\
\hline JORGE SOLLA & SIM \\
\hline JORGE TADEU MUDALEN & $\mathrm{NAO}$ \\
\hline JORGINHO MELLO & SIM \\
\hline JOSE AIRTON CIRILO & SIM \\
\hline JOSE CARLOS ALELUIA & SIM \\
\hline JOSE CARLOS ARAUJO & SIM \\
\hline JOSE FOGACA & $\mathrm{NAO}$ \\
\hline JOSE GUIMARAES & SIM \\
\hline JOSE MAIA FILHO & <------> \\
\hline JOSE MENTOR & SIM \\
\hline JOSE NUNES & SIM \\
\hline JOSE OTAVIO GERMANO & $\mathrm{NAO}$ \\
\hline JOSE PRIANTE & SIM \\
\hline JOSE REINALDO & SIM \\
\hline JOSE ROCHA & SIM \\
\hline JOSE STEDILE & $\mathrm{NAO}$ \\
\hline JOSI NUNES & SIM \\
\hline JOSUE BENGTSON & NAO \\
\hline JOVAIR ARANTES & SIM \\
\hline JOZI ROCHA & SIM \\
\hline
\end{tabular}




\begin{tabular}{|c|c|}
\hline JULIA MARINHO & NAO \\
\hline JULIO CESAR & SIM \\
\hline JULIO DELGADO & NAO \\
\hline JULIO LOPES & SIM \\
\hline JUNIOR MARRECA & NAO \\
\hline JUSCELINO FILHO & SIM \\
\hline JUTAHY JUNIOR & $\langle-----\cdot->$ \\
\hline KAIO MANICOBA & $\mid<------>$ \\
\hline KEIKO OTA & SIM \\
\hline LAERCIO OLIVEIRA & $\mathrm{NAO}$ \\
\hline LAERTE BESSA & SIM \\
\hline LAUDIVIO CARVALHO & SIM \\
\hline LAZARO BOTELHO & SIM \\
\hline LEANDRE & NAO \\
\hline LELO COIMBRA & SIM \\
\hline LEO DE BRITO & SIM \\
\hline LEONARDO MONTEIRO & SIM \\
\hline LEONARDO PICCIANI & SIM \\
\hline LEONARDO QUINTAO & SIM \\
\hline LEONIDAS CRISTINO & SIM \\
\hline LEOPOLDO MEYER & NAO \\
\hline LINCOLN PORTELA & SIM \\
\hline LINDOMAR GARCON & SIM \\
\hline LOBBE NETO & $\mathrm{NAO}$ \\
\hline LUCAS VERGILIO & NAO \\
\hline LUCIANA SANTOS & SIM \\
\hline LUCIANO DUCCI & $\mathrm{NAO}$ \\
\hline LUCIO MOSQUINI & SIM \\
\hline \begin{tabular}{|l} 
LUCIO VALE \\
\end{tabular} & SIM \\
\hline LUCIO VIEIRA LIMA & SIM \\
\hline LUIS CARLOS HEINZE & NAO \\
\hline LUIS TIBE & SIM \\
\hline LUIZ CARLOS BUSATO & SIM \\
\hline LUIZ CARLOS HAULY & NAO \\
\hline LUIZ CARLOS RAMOS & SIM \\
\hline LUIZ CLAUDIO & SIM \\
\hline LUIZ COUTO & SIM \\
\hline LUIZ FERNANDO FARIA & SIM \\
\hline LUIZ LAURO FILHO & $\mid<----\cdot->$ \\
\hline LUIZ NISHIMORI & SIM \\
\hline LUIZ SERGIO & $\mid<----\cdot->$ \\
\hline LUIZA ERUNDINA & $|<------\rangle$ \\
\hline LUIZIANNE LINS & $\mid<----\cdot->$ \\
\hline MACEDO & SIM \\
\hline MAGDA MOFATTO & SIM \\
\hline MAJOR OLIMPIO & $\langle-----\cdot>$ \\
\hline MANDETTA & NAO \\
\hline MANOEL JUNIOR & SIM \\
\hline MARA GABRILLI & $\mathrm{NAO}$ \\
\hline MARCELO AGUIAR & SIM \\
\hline
\end{tabular}




\begin{tabular}{|c|c|}
\hline MARCELO ALVARO ANTONIO & SIM \\
\hline MARCELO ARO & SIM \\
\hline MARCELO BELINATI & NAO \\
\hline MARCELO CASTRO & SIM \\
\hline MARCELO MATOS & NAO \\
\hline MARCELO SQUASSONI & SIM \\
\hline MARCIO ALVINO & SIM \\
\hline MARCIO MARINHO & SIM \\
\hline MARCO MAIA & SIM \\
\hline MARCO TEBALDI & NAO \\
\hline MARCON & <-------> \\
\hline MARCOS ABRAO & NAO \\
\hline MARCOS MONTES & SIM \\
\hline MARCOS REATEGUI & NAO \\
\hline MARCOS ROGERIO & NAO \\
\hline MARCOS ROTTA & NAO \\
\hline MARCOS SOARES & SIM \\
\hline MARCUS PESTANA & $\mathrm{NAO}$ \\
\hline MARCUS VICENTE & SIM \\
\hline MARGARIDA SALOMAO & SIM \\
\hline MARIA DO ROSARIO & SIM \\
\hline MARIA HELENA & NAO \\
\hline MARIANA CARVALHO & NAO \\
\hline MARINALDO ROSENDO & SIM \\
\hline MARINHA RAUPP & SIM \\
\hline MARIO HERINGER & NAO \\
\hline MARIO NEGROMONTE JR. & SIM \\
\hline MARQUINHO MENDES & SIM \\
\hline MARX BELTRAO & NAO \\
\hline MAURICIO QUINTELLA LESSA & SIM \\
\hline MAURO LOPES & SIM \\
\hline MAURO MARIANI & SIM \\
\hline MAURO PEREIRA & SIM \\
\hline MAX FILHO & $\mathrm{NAO}$ \\
\hline MENDONCA FILHO & NAO \\
\hline MIGUEL HADDAD & NAO \\
\hline MIGUEL LOMBARDI & SIM \\
\hline MILTON MONTI & SIM \\
\hline MIRO TEIXEIRA & NAO \\
\hline MISAEL VARELLA & $<------->$ \\
\hline MISSIONARIO JOSE OLIMPIO & NAO \\
\hline MOEMA GRAMACHO & SIM \\
\hline MORONI TORGAN & NAO \\
\hline MOSES RODRIGUES & NAO \\
\hline NELSON MARCHEZAN JUNIOR & NAO \\
\hline NELSON MARQUEZELLI & SIM \\
\hline NELSON MEURER & SIM \\
\hline NEWTON CARDOSO JR & SIM \\
\hline NILSON LEITAO & $<------->$ \\
\hline NILSON PINTO & NAO \\
\hline
\end{tabular}




\begin{tabular}{|c|c|}
\hline NILTO TATTO & SIM \\
\hline NILTON CAPIXABA & SIM \\
\hline ODELMO LEAO & NAO \\
\hline ODORICO MONTEIRO & SIM \\
\hline ONYX LORENZONI & <-------> \\
\hline ORLANDO SILVA & SIM \\
\hline OSMAR BERTOLDI & NAO \\
\hline OSMAR SERRAGLIO & $<------->$ \\
\hline OSMAR TERRA & SIM \\
\hline OTAVIO LEITE & NAO \\
\hline PADRE JOAO & <-------> \\
\hline PAES LANDIM & SIM \\
\hline PASTOR EURICO & NAO \\
\hline PASTOR FRANKLIN & SIM \\
\hline PAUDERNEY AVELINO & NAO \\
\hline PAULAO & SIM \\
\hline PAULO ABI-ACKEL & NAO \\
\hline PAULO AZI & <<-------> \\
\hline PAULO FEIJO & SIM \\
\hline PAULO FOLETTO & NAO \\
\hline PAULO FREIRE & NAO \\
\hline PAULO MAGALHAES & SIM \\
\hline PAULO MALUF & SIM \\
\hline PAULO PEREIRA DA SILVA & NAO \\
\hline PAULO PIMENTA & SIM \\
\hline PAULO TEIXEIRA & SIM \\
\hline PEDRO CHAVES & SIM \\
\hline PEDRO CUNHA LIMA & NAO \\
\hline PEDRO FERNANDES & SIM \\
\hline PEDRO UCZAI & <-------> \\
\hline PEDRO VILELA & NAO \\
\hline POMPEO DE MATTOS & NAO \\
\hline PR. MARCO FELICIANO & <-------> \\
\hline PROFESSOR VICTORIO GALLI & NAO \\
\hline $\begin{array}{l}\text { PROFESSORA DORINHA SEABRA } \\
\text { REZEN }\end{array}$ & NAO \\
\hline PROFESSORA MARCIVANIA & $<------->$ \\
\hline RAFAEL MOTTA & SIM \\
\hline RAIMUNDO GOMES DE MATOS & NAO \\
\hline RAQUEL MUNIZ & NAO \\
\hline RAUL JUNGMANN & NAO \\
\hline REGINALDO LOPES & SIM \\
\hline REMIDIO MONAI & <-------> \\
\hline RENATA ABREU & SIM \\
\hline RENATO MOLLING & <<-------> \\
\hline RENZO BRAZ & SIM \\
\hline RICARDO BARROS & SIM \\
\hline RICARDO IZAR & SIM \\
\hline RICARDO TEOBALDO & SIM \\
\hline RICARDO TRIPOLI & NAO \\
\hline
\end{tabular}




\begin{tabular}{|c|c|}
\hline ROBERTO ALVES & SIM \\
\hline ROBERTO BALESTRA & $\mathrm{NAO}$ \\
\hline ROBERTO BRITTO & SIM \\
\hline ROBERTO FREIRE & $<------>>$ \\
\hline ROBERTO GOES & NAO \\
\hline ROBERTO SALES & SIM \\
\hline $\mathrm{ROCHA}$ & $\mathrm{NAO}$ \\
\hline RODRIGO DE CASTRO & NAO \\
\hline RODRIGO MAIA & SIM \\
\hline RODRIGO MARTINS & NAO \\
\hline RODRIGO PACHECO & SIM \\
\hline ROGERIO MARINHO & $\mathrm{NAO}$ \\
\hline ROGERIO PENINHA MENDONCA & SIM \\
\hline ROGERIO ROSSO & SIM \\
\hline ROMULO GOUVEIA & SIM \\
\hline RONALDO BENEDET & SIM \\
\hline RONALDO CARLETTO & SIM \\
\hline RONALDO FONSECA & $\mathrm{NAO}$ \\
\hline RONALDO LESSA & NAO \\
\hline RONALDO MARTINS & SIM \\
\hline RONALDO NOGUEIRA & NAO \\
\hline RONEY NEMER & $<------->$ \\
\hline ROSANGELA GOMES & SIM \\
\hline ROSSONI & $\mathrm{NAO}$ \\
\hline RUBENS BUENO & NAO \\
\hline RUBENS OTONI & SIM \\
\hline RUBENS PEREIRA JUNIOR & SIM \\
\hline SAGUAS MORAES & SIM \\
\hline SAMUEL MOREIRA & NAO \\
\hline SANDES JUNIOR & SIM \\
\hline SANDRO ALEX & $\mathrm{NAO}$ \\
\hline SARAIVA FELIPE & SIM \\
\hline SARNEY FILHO & SIM \\
\hline SERGIO BRITO & SIM \\
\hline SERGIO MORAES & $\mathrm{NAO}$ \\
\hline SERGIO REIS & SIM \\
\hline SERGIO SOUZA & SIM \\
\hline SERGIO VIDIGAL & NAO \\
\hline SERGIO ZVEITER & SIM \\
\hline SHERIDAN & $\mathrm{NAO}$ \\
\hline SIBA MACHADO & SIM \\
\hline SILAS BRASILEIRO & $<------->$ \\
\hline SILAS CAMARA & SIM \\
\hline SILAS FREIRE & SIM \\
\hline SILVIO COSTA & SIM \\
\hline SILVIO TORRES & $\mathrm{NAO}$ \\
\hline SIMAO SESSIM & SIM \\
\hline SIMONE MORGADO & SIM \\
\hline SORAYA SANTOS & SIM \\
\hline SOSTENES CAVALCANTE & NAO \\
\hline
\end{tabular}




\begin{tabular}{|c|c|}
\hline STEFANO AGUIAR & NAO \\
\hline SUBTENENTE GONZAGA & NAO \\
\hline TADEU ALENCAR & SIM \\
\hline TAKAYAMA & $\langle------>$ \\
\hline TENENTE LUCIO & NAO \\
\hline TEREZA CRISTINA & SIM \\
\hline TIA ERON & SIM \\
\hline TIRIRICA & SIM \\
\hline TONINHO PINHEIRO & SIM \\
\hline TONINHO WANDSCHEER & SIM \\
\hline ULDURICO JUNIOR & SIM \\
\hline VALADARES FILHO & $\mathrm{NAO}$ \\
\hline VALDIR COLATTO & SIM \\
\hline VALMIR ASSUNCAO & SIM \\
\hline VALMIR PRASCIDELLI & SIM \\
\hline VALTENIR PEREIRA & SIM \\
\hline VANDER LOUBET & SIM \\
\hline VANDERLEI MACRIS & $\mid<------>$ \\
\hline VENEZIANO VITAL DO REGO & NAO \\
\hline VICENTE CANDIDO & SIM \\
\hline VICENTINHO & SIM \\
\hline VICENTINHO JUNIOR & SIM \\
\hline VICTOR MENDES & SIM \\
\hline VINICIUS CARVALHO & SIM \\
\hline VINICIUS GURGEL & $\mid<-----\cdot>$ \\
\hline \begin{tabular}{|l|} 
VITOR LIPPI \\
\end{tabular} & NAO \\
\hline VITOR VALIM & NAO \\
\hline WADSON RIBEIRO & SIM \\
\hline WALDENOR PEREIRA & SIM \\
\hline WALDIR MARANHAO & SIM \\
\hline WALNEY ROCHA & NAO \\
\hline WALTER ALVES & SIM \\
\hline WALTER IHOSHI & SIM \\
\hline WASHINGTON REIS & SIM \\
\hline WELITON PRADO & NAO \\
\hline WELLINGTON ROBERTO & SIM \\
\hline WEVERTON ROCHA & $\mathrm{NAO}$ \\
\hline WILLIAM WOO & SIM \\
\hline WILSON FILHO & SIM \\
\hline WLADIMIR COSTA & $\langle----\cdot->>$ \\
\hline WOLNEY QUEIROZ & NAO \\
\hline ZE CARLOS & $\langle------>$ \\
\hline ZE GERALDO & SIM \\
\hline ZE SILVA & $\mathrm{NAO}$ \\
\hline ZECA CAVALCANTI & SIM \\
\hline ZECA DIRCEU & SIM \\
\hline ZECA DO PT & SIM \\
\hline ZENAIDE MAIA & SIM \\
\hline
\end{tabular}

<-------> = ausente 
Fonte: elaboração própria, a partir dos dados de votação disponibilizados pela Câmara dos Deputados.

Tabela 22 - Votos nominais para a matéria M5

\begin{tabular}{|c|c|}
\hline Deputado (a) & Voto \\
\hline ABEL MESQUITA JR. & NAO \\
\hline ADAIL CARNEIRO & NAO \\
\hline ADALBERTO CAVALCANTI & $\langle<----\cdot->$ \\
\hline ADELMO CARNEIRO LEAO & SIM \\
\hline ADELSON BARRETO & NAO \\
\hline ADEMIR CAMILO & NAO \\
\hline ADILTON SACHETTI & NAO \\
\hline AELTON FREITAS & SIM \\
\hline AFONSO FLORENCE & SIM \\
\hline AFONSO HAMM & NAO \\
\hline AFONSO MOTTA & NAO \\
\hline AGUINALDO RIBEIRO & SIM \\
\hline ALAN RICK & NAO \\
\hline ALBERTO FILHO & SIM \\
\hline ALBERTO FRAGA & NAO \\
\hline ALCEU MOREIRA & $\mathrm{NAO}$ \\
\hline ALESSANDRO MOLON & SIM \\
\hline ALEX CANZIANI & SIM \\
\hline ALEX MANENTE & $\mathrm{NAO}$ \\
\hline ALEXANDRE BALDY & NAO \\
\hline ALEXANDRE LEITE & NAO \\
\hline ALEXANDRE SERFIOTIS & $\mathrm{NAO}$ \\
\hline ALEXANDRE VALLE & $\mathrm{NAO}$ \\
\hline ALFREDO KAEFER & NAO \\
\hline ALFREDO NASCIMENTO & SIM \\
\hline ALICE PORTUGAL & SIM \\
\hline ALIEL MACHADO & NAO \\
\hline ALTINEU CORTES & $\langle------>$ \\
\hline ALUISIO MENDES & SIM \\
\hline ANA PERUGINI & SIM \\
\hline ANDERSON FERREIRA & SIM \\
\hline ANDRE ABDON & SIM \\
\hline ANDRE FIGUEIREDO & NAO \\
\hline ANDRE FUFUCA & SIM \\
\hline ANDRE MOURA & NAO \\
\hline ANDRES SANCHEZ & SIM \\
\hline ANGELIM & SIM \\
\hline ANIBAL GOMES & SIM \\
\hline
\end{tabular}




\begin{tabular}{|c|c|}
\hline ANTONIO BALHMANN & SIM \\
\hline ANTONIO BRITO & ABSTENCAO \\
\hline ANTONIO BULHOES & SIM \\
\hline ANTONIO CARLOS MENDES THAME & NAO \\
\hline ANTONIO IMBASSAHY & NAO \\
\hline ANTONIO JACOME & NAO \\
\hline ARLINDO CHINAGLIA & SIM \\
\hline ARNALDO FARIA DE SA & NAO \\
\hline ARNALDO JORDY & NAO \\
\hline ARNON BEZERRA & SIM \\
\hline ARTHUR LIRA & SIM \\
\hline ARTHUR OLIVEIRA MAIA & NAO \\
\hline ARTHUR VIRGILIO BISNETO & NAO \\
\hline ASSIS CARVALHO & SIM \\
\hline ASSIS DO COUTO & $<------>>$ \\
\hline ATILA LINS & SIM \\
\hline ATILA LIRA & SIM \\
\hline AUGUSTO CARVALHO & NAO \\
\hline AUGUSTO COUTINHO & NAO \\
\hline AUREO & NAO \\
\hline BACELAR & SIM \\
\hline BALEIA ROSSI & SIM \\
\hline BEBETO & NAO \\
\hline BENEDITA DA SILVA & SIM \\
\hline BENITO GAMA & NAO \\
\hline BENJAMIN MARANHAO & NAO \\
\hline BETINHO GOMES & NAO \\
\hline BETO FARO & SIM \\
\hline BETO MANSUR & SIM \\
\hline BETO ROSADO & NAO \\
\hline BETO SALAME & SIM \\
\hline BILAC PINTO & SIM \\
\hline BOHN GASS & SIM \\
\hline BONIFACIO DE ANDRADA & NAO \\
\hline BRUNA FURLAN & NAO \\
\hline BRUNNY & SIM \\
\hline BRUNO ARAUJO & NAO \\
\hline BRUNO COVAS & NAO \\
\hline CABO DACIOLO & NAO \\
\hline CABO SABINO & SIM \\
\hline CABUCU BORGES & SIM \\
\hline CACA LEAO & SIM \\
\hline CAETANO & SIM \\
\hline CAIO NARCIO & NAO \\
\hline CAPITAO AUGUSTO & SIM \\
\hline CARLOS ANDRADE & NAO \\
\hline CARLOS BEZERRA & SIM \\
\hline CARLOS EDUARDO CADOCA & SIM \\
\hline CARLOS GOMES & SIM \\
\hline CARLOS HENRIQUE GAGUIM & SIM \\
\hline
\end{tabular}




\begin{tabular}{|c|c|}
\hline CARLOS MANATO & NAO \\
\hline CARLOS MARUN & SIM \\
\hline CARLOS MELLES & SIM \\
\hline CARLOS SAMPAIO & $\mathrm{NAO}$ \\
\hline CARLOS ZARATTINI & SIM \\
\hline CARMEN ZANOTTO & NAO \\
\hline CELIO SILVEIRA & $\mathrm{NAO}$ \\
\hline CELSO JACOB & SIM \\
\hline CELSO MALDANER & SIM \\
\hline CELSO PANSERA & SIM \\
\hline CELSO RUSSOMANNO & SIM \\
\hline CESAR HALUM & SIM \\
\hline CESAR MESSIAS & NAO \\
\hline CESAR SOUZA & SIM \\
\hline CHICO ALENCAR & NAO \\
\hline CHICO D ANGELO & SIM \\
\hline CHICO LOPES & SIM \\
\hline CHRISTIANE DE SOUZA YARED & NAO \\
\hline CICERO ALMEIDA & NAO \\
\hline CLARISSA GAROTINHO & $\mathrm{NAO}$ \\
\hline CLAUDIO CAJADO & SIM \\
\hline CLEBER VERDE & SIM \\
\hline CONCEICAO SAMPAIO & NAO \\
\hline COVATTI FILHO & NAO \\
\hline CRISTIANE BRASIL & NAO \\
\hline DAGOBERTO & NAO \\
\hline DAMIAO FELICIANO & $\mathrm{NAO}$ \\
\hline DAMINA PEREIRA & SIM \\
\hline DANIEL ALMEIDA & SIM \\
\hline DANIEL COELHO & $\mathrm{NAO}$ \\
\hline DANIEL VILELA & SIM \\
\hline DANILO FORTE & NAO \\
\hline DANRLEI DE DEUS HINTERHOLZ & SIM \\
\hline DARCISIO PERONDI & SIM \\
\hline DAVIDSON MAGALHAES & SIM \\
\hline DECIO LIMA & SIM \\
\hline DELEGADO EDER MAURO & SIM \\
\hline DELEGADO EDSON MOREIRA & SIM \\
\hline DELEGADO WALDIR & NAO \\
\hline DELEY & NAO \\
\hline DIEGO ANDRADE & SIM \\
\hline DIEGO GARCIA & $\mathrm{NAO}$ \\
\hline DILCEU SPERAFICO & SIM \\
\hline DIMAS FABIANO & $\mathrm{NAO}$ \\
\hline DOMINGOS NETO & SIM \\
\hline DOMINGOS SAVIO & $<------->$ \\
\hline DR. JOAO & SIM \\
\hline DR. JORGE SILVA & SIM \\
\hline DR. SINVAL MALHEIROS & $\mathrm{NAO}$ \\
\hline DULCE MIRANDA & SIM \\
\hline
\end{tabular}




\begin{tabular}{|c|c|}
\hline EDINHO BEZ & SIM \\
\hline EDIO LOPES & SIM \\
\hline EDMAR ARRUDA & SIM \\
\hline EDMILSON RODRIGUES & NAO \\
\hline EDUARDO BARBOSA & NAO \\
\hline EDUARDO BOLSONARO & NAO \\
\hline EDUARDO CUNHA & ART. 17 \\
\hline EDUARDO CURY & NAO \\
\hline EDUARDO DA FONTE & SIM \\
\hline EFRAIM FILHO & NAO \\
\hline ELCIONE BARBALHO & SIM \\
\hline ELI CORREA FILHO & $\mathrm{NAO}$ \\
\hline ELIZEU DIONIZIO & SIM \\
\hline ELIZIANE GAMA & $\mathrm{NAO}$ \\
\hline ELMAR NASCIMENTO & SIM \\
\hline ENIO VERRI & SIM \\
\hline ERIKA KOKAY & <------> \\
\hline ERIVELTON SANTANA & $\mathrm{NAO}$ \\
\hline EROS BIONDINI & NAO \\
\hline ESPERIDIAO AMIN & $\mathrm{NAO}$ \\
\hline EVAIR DE MELO & NAO \\
\hline EVANDRO GUSSI & NAO \\
\hline EVANDRO ROGERIO ROMAN & SIM \\
\hline EXPEDITO NETTO & $<------->$ \\
\hline EZEQUIEL FONSECA & SIM \\
\hline EZEQUIEL TEIXEIRA & $<------->$ \\
\hline FABIANO HORTA & SIM \\
\hline FABIO FARIA & SIM \\
\hline FABIO GARCIA & NAO \\
\hline FABIO MITIDIERI & SIM \\
\hline FABIO RAMALHO & SIM \\
\hline FABIO REIS & NAO \\
\hline FABIO SOUSA & NAO \\
\hline FAUSTO PINATO & $\mathrm{NAO}$ \\
\hline FELIPE BORNIER & NAO \\
\hline FELIPE MAIA & $\mathrm{NAO}$ \\
\hline FELIX MENDONCA JUNIOR & NAO \\
\hline FERNANDO COELHO FILHO & $\mathrm{NAO}$ \\
\hline FERNANDO JORDAO & SIM \\
\hline FERNANDO MARRONI & SIM \\
\hline FERNANDO MONTEIRO & SIM \\
\hline FERNANDO TORRES & <-------> \\
\hline FLAVIA MORAIS & NAO \\
\hline FLAVIANO MELO & SIM \\
\hline FLAVINHO & $\mathrm{NAO}$ \\
\hline FRANCISCO CHAPADINHA & SIM \\
\hline FRANCISCO FLORIANO & SIM \\
\hline GABRIEL GUIMARAES & SIM \\
\hline GENECIAS NORONHA & NAO \\
\hline GEOVANIA DE SA & NAO \\
\hline
\end{tabular}




\begin{tabular}{|c|c|}
\hline GERALDO RESENDE & SIM \\
\hline GIACOBO & SIM \\
\hline GILBERTO NASCIMENTO & $\mathrm{NAO}$ \\
\hline GIOVANI CHERINI & $\mathrm{NAO}$ \\
\hline GIUSEPPE VECCI & NAO \\
\hline GIVALDO CARIMBAO & SIM \\
\hline GIVALDO VIEIRA & SIM \\
\hline GLAUBER BRAGA & NAO \\
\hline GONZAGA PATRIOTA & NAO \\
\hline GORETE PEREIRA & SIM \\
\hline GOULART & SIM \\
\hline GUILHERME MUSSI & SIM \\
\hline HEITOR SCHUCH & $\mathrm{NAO}$ \\
\hline HELDER SALOMAO & SIM \\
\hline HELIO LEITE & $\mathrm{NAO}$ \\
\hline HENRIQUE FONTANA & SIM \\
\hline HERACLITO FORTES & $\mathrm{NAO}$ \\
\hline HERCULANO PASSOS & SIM \\
\hline HERMES PARCIANELLO & NAO \\
\hline HEULER CRUVINEL & $\mathrm{NAO}$ \\
\hline HILDO ROCHA & SIM \\
\hline HIRAN GONCALVES & SIM \\
\hline HISSA ABRAHAO & $\mathrm{NAO}$ \\
\hline HUGO LEAL & SIM \\
\hline HUGO MOTTA & SIM \\
\hline INDIO DA COSTA & SIM \\
\hline IRACEMA PORTELLA & SIM \\
\hline IRAJA ABREU & SIM \\
\hline IRMAO LAZARO & NAO \\
\hline IVAN VALENTE & $\mathrm{NAO}$ \\
\hline IZALCI & $\mathrm{NAO}$ \\
\hline JAIME MARTINS & SIM \\
\hline JAIR BOLSONARO & $\mathrm{NAO}$ \\
\hline JANDIRA FEGHALI & SIM \\
\hline JANETE CAPIBERIBE & $<------->$ \\
\hline JARBAS VASCONCELOS & $\mathrm{NAO}$ \\
\hline JEAN WYLLYS & NAO \\
\hline JEFFERSON CAMPOS & $\mathrm{NAO}$ \\
\hline JERONIMO GOERGEN & $\mathrm{NAO}$ \\
\hline JESSICA SALES & SIM \\
\hline $\mathrm{JHC}$ & $\mathrm{NAO}$ \\
\hline JHONATAN DE JESUS & $\mathrm{NAO}$ \\
\hline JO MORAES & SIM \\
\hline JOAO ARRUDA & NAO \\
\hline JOAO CAMPOS & $\mathrm{NAO}$ \\
\hline JOAO CARLOS BACELAR & SIM \\
\hline JOAO CASTELO & $\mathrm{NAO}$ \\
\hline JOAO DANIEL & SIM \\
\hline JOAO DERLY & $\mathrm{NAO}$ \\
\hline JOAO FERNANDO COUTINHO & NAO \\
\hline
\end{tabular}




\begin{tabular}{|c|c|}
\hline JOAO GUALBERTO & NAO \\
\hline JOAO MARCELO SOUZA & SIM \\
\hline JOAO PAULO PAPA & NAO \\
\hline JOAO RODRIGUES & $\mathrm{NAO}$ \\
\hline JOAQUIM PASSARINHO & SIM \\
\hline JONY MARCOS & SIM \\
\hline JORGE BOEIRA & $\mathrm{NAO}$ \\
\hline JORGE CORTE REAL & SIM \\
\hline JORGE SOLLA & SIM \\
\hline JORGE TADEU MUDALEN & NAO \\
\hline JORGINHO MELLO & SIM \\
\hline JOSE AIRTON CIRILO & SIM \\
\hline JOSE CARLOS ALELUIA & SIM \\
\hline JOSE CARLOS ARAUJO & $<------>>$ \\
\hline JOSE FOGACA & $\mathrm{NAO}$ \\
\hline JOSE GUIMARAES & SIM \\
\hline JOSE MENTOR & SIM \\
\hline JOSE NUNES & SIM \\
\hline JOSE OTAVIO GERMANO & NAO \\
\hline JOSE PRIANTE & SIM \\
\hline JOSE REINALDO & SIM \\
\hline JOSE ROCHA & SIM \\
\hline JOSE STEDILE & NAO \\
\hline JOSI NUNES & $\mathrm{NAO}$ \\
\hline JOSUE BENGTSON & $\mathrm{NAO}$ \\
\hline JOVAIR ARANTES & SIM \\
\hline JOZI ROCHA & SIM \\
\hline JULIA MARINHO & NAO \\
\hline JULIO CESAR & SIM \\
\hline JULIO DELGADO & $<------->$ \\
\hline JULIO LOPES & SIM \\
\hline JUNIOR MARRECA & $<------->$ \\
\hline JUSCELINO FILHO & SIM \\
\hline JUTAHY JUNIOR & $\mid<------>$ \\
\hline KAIO MANICOBA & $\mathrm{NAO}$ \\
\hline KEIKO OTA & SIM \\
\hline LAERCIO OLIVEIRA & $\mathrm{NAO}$ \\
\hline LAERTE BESSA & SIM \\
\hline LAUDIVIO CARVALHO & $\mathrm{NAO}$ \\
\hline LAZARO BOTELHO & SIM \\
\hline LEANDRE & $\mathrm{NAO}$ \\
\hline LELO COIMBRA & $\mathrm{NAO}$ \\
\hline LEO DE BRITO & SIM \\
\hline LEONARDO MONTEIRO & SIM \\
\hline LEONARDO PICCIANI & SIM \\
\hline LEONARDO QUINTAO & SIM \\
\hline LEONIDAS CRISTINO & SIM \\
\hline LEOPOLDO MEYER & NAO \\
\hline LINCOLN PORTELA & $<------->$ \\
\hline LINDOMAR GARCON & SIM \\
\hline
\end{tabular}




\begin{tabular}{|c|c|}
\hline LOBBE NETO & NAO \\
\hline LUCAS VERGILIO & NAO \\
\hline LUCIANA SANTOS & SIM \\
\hline LUCIANO DUCCI & $\mathrm{NAO}$ \\
\hline LUCIO MOSQUINI & SIM \\
\hline LUCIO VALE & SIM \\
\hline LUCIO VIEIRA LIMA & SIM \\
\hline LUIS CARLOS HEINZE & NAO \\
\hline LUIS TIBE & SIM \\
\hline LUIZ CARLOS BUSATO & SIM \\
\hline LUIZ CARLOS HAULY & $\mathrm{NAO}$ \\
\hline LUIZ CARLOS RAMOS & $\mathrm{NAO}$ \\
\hline LUIZ CLAUDIO & SIM \\
\hline LUIZ COUTO & SIM \\
\hline LUIZ FERNANDO FARIA & SIM \\
\hline LUIZ LAURO FILHO & SIM \\
\hline LUIZ NISHIMORI & SIM \\
\hline LUIZ SERGIO & SIM \\
\hline LUIZA ERUNDINA & $\mid<----\cdot->$ \\
\hline LUIZIANNE LINS & $\mid<----\cdot->$ \\
\hline MACEDO & SIM \\
\hline MAGDA MOFATTO & SIM \\
\hline MAJOR OLIMPIO & $\mathrm{NAO}$ \\
\hline MANDETTA & NAO \\
\hline MANOEL JUNIOR & SIM \\
\hline MARA GABRILLI & NAO \\
\hline MARCELO AGUIAR & SIM \\
\hline MARCELO ALVARO ANTONIO & NAO \\
\hline MARCELO ARO & NAO \\
\hline MARCELO BELINATI & NAO \\
\hline MARCELO CASTRO & SIM \\
\hline MARCELO MATOS & NAO \\
\hline MARCELO SQUASSONI & NAO \\
\hline MARCIO ALVINO & SIM \\
\hline MARCIO MARINHO & NAO \\
\hline MARCO MAIA & SIM \\
\hline MARCO TEBALDI & NAO \\
\hline MARCON & $\mid<----\cdot->$ \\
\hline MARCOS ABRAO & NAO \\
\hline MARCOS MONTES & SIM \\
\hline MARCOS REATEGUI & $\mid<-----\cdot>$ \\
\hline MARCOS ROGERIO & NAO \\
\hline MARCOS ROTTA & NAO \\
\hline MARCOS SOARES & NAO \\
\hline MARCUS PESTANA & NAO \\
\hline MARCUS VICENTE & NAO \\
\hline MARGARIDA SALOMAO & SIM \\
\hline MARIA DO ROSARIO & SIM \\
\hline MARIA HELENA & NAO \\
\hline MARIANA CARVALHO & NAO \\
\hline
\end{tabular}




\begin{tabular}{|c|c|}
\hline MARINALDO ROSENDO & NAO \\
\hline MARINHA RAUPP & <-------> \\
\hline MARIO HERINGER & NAO \\
\hline MARIO NEGROMONTE JR. & SIM \\
\hline MARQUINHO MENDES & SIM \\
\hline MARX BELTRAO & SIM \\
\hline MAURICIO QUINTELLA LESSA & SIM \\
\hline MAURO LOPES & SIM \\
\hline MAURO MARIANI & SIM \\
\hline MAURO PEREIRA & NAO \\
\hline MAX FILHO & NAO \\
\hline MENDONCA FILHO & NAO \\
\hline MERLONG SOLANO & SIM \\
\hline MIGUEL HADDAD & NAO \\
\hline MIGUEL LOMBARDI & SIM \\
\hline MILTON MONTI & SIM \\
\hline MIRO TEIXEIRA & NAO \\
\hline MISAEL VARELLA & SIM \\
\hline MISSIONARIO JOSE OLIMPIO & NAO \\
\hline MOEMA GRAMACHO & SIM \\
\hline MORONI TORGAN & NAO \\
\hline MOSES RODRIGUES & NAO \\
\hline NELSON MARCHEZAN JUNIOR & NAO \\
\hline NELSON MARQUEZELLI & SIM \\
\hline NELSON MEURER & SIM \\
\hline NEWTON CARDOSO JR & SIM \\
\hline NILSON LEITAO & $\mathrm{NAO}$ \\
\hline NILSON PINTO & $\mathrm{NAO}$ \\
\hline NILTO TATTO & SIM \\
\hline NILTON CAPIXABA & NAO \\
\hline ODELMO LEAO & $\mathrm{NAO}$ \\
\hline ODORICO MONTEIRO & SIM \\
\hline ONYX LORENZONI & NAO \\
\hline ORLANDO SILVA & SIM \\
\hline OSMAR BERTOLDI & $\mathrm{NAO}$ \\
\hline OSMAR SERRAGLIO & <-------> \\
\hline OSMAR TERRA & SIM \\
\hline OTAVIO LEITE & $\mathrm{NAO}$ \\
\hline PADRE JOAO & <-------> \\
\hline PAES LANDIM & SIM \\
\hline PASTOR EURICO & $\mathrm{NAO}$ \\
\hline PASTOR FRANKLIN & $\mathrm{NAO}$ \\
\hline PAUDERNEY AVELINO & NAO \\
\hline PAULAO & SIM \\
\hline PAULO ABI-ACKEL & $\mathrm{NAO}$ \\
\hline PAULO AZI & SIM \\
\hline PAULO FEIJO & NAO \\
\hline PAULO FOLETTO & $\mathrm{NAO}$ \\
\hline PAULO FREIRE & $\mathrm{NAO}$ \\
\hline PAULO MAGALHAES & SIM \\
\hline
\end{tabular}




\begin{tabular}{|c|c|}
\hline PAULO MALUF & SIM \\
\hline PAULO PEREIRA DA SILVA & NAO \\
\hline PAULO PIMENTA & SIM \\
\hline PAULO TEIXEIRA & SIM \\
\hline PEDRO CHAVES & SIM \\
\hline PEDRO CUNHA LIMA & NAO \\
\hline PEDRO FERNANDES & SIM \\
\hline PEDRO UCZAI & $\mid<------>$ \\
\hline PEDRO VILELA & NAO \\
\hline POMPEO DE MATTOS & NAO \\
\hline PR. MARCO FELICIANO & $<------>$ \\
\hline PROFESSOR VICTORIO GALLI & $\mathrm{NAO}$ \\
\hline $\begin{array}{l}\text { PROFESSORA DORINHA SEABRA } \\
\text { REZEN }\end{array}$ & NAO \\
\hline PROFESSORA MARCIVANIA & $\mid<----\cdot->$ \\
\hline RAFAEL MOTTA & $\langle------>>$ \\
\hline RAIMUNDO GOMES DE MATOS & NAO \\
\hline RAQUEL MUNIZ & NAO \\
\hline RAUL JUNGMANN & NAO \\
\hline REGINALDO LOPES & SIM \\
\hline REMIDIO MONAI & SIM \\
\hline RENATA ABREU & SIM \\
\hline RENATO MOLLING & NAO \\
\hline RENZO BRAZ & NAO \\
\hline RICARDO BARROS & SIM \\
\hline RICARDO IZAR & SIM \\
\hline RICARDO TEOBALDO & SIM \\
\hline RICARDO TRIPOLI & $\mathrm{NAO}$ \\
\hline ROBERTO ALVES & SIM \\
\hline ROBERTO BALESTRA & $<------>>$ \\
\hline ROBERTO BRITTO & SIM \\
\hline ROBERTO FREIRE & NAO \\
\hline ROBERTO GOES & NAO \\
\hline ROBERTO SALES & $\mid<------>>$ \\
\hline $\mathrm{ROCHA}$ & NAO \\
\hline RODRIGO DE CASTRO & NAO \\
\hline RODRIGO MAIA & SIM \\
\hline RODRIGO MARTINS & $\mathrm{NAO}$ \\
\hline RODRIGO PACHECO & SIM \\
\hline ROGERIO MARINHO & NAO \\
\hline ROGERIO PENINHA MENDONCA & SIM \\
\hline ROGERIO ROSSO & SIM \\
\hline ROMULO GOUVEIA & SIM \\
\hline RONALDO BENEDET & SIM \\
\hline RONALDO CARLETTO & SIM \\
\hline RONALDO FONSECA & $\mathrm{NAO}$ \\
\hline RONALDO LESSA & NAO \\
\hline RONALDO MARTINS & NAO \\
\hline RONALDO NOGUEIRA & NAO \\
\hline RONEY NEMER & SIM \\
\hline
\end{tabular}




\begin{tabular}{|c|c|}
\hline ROSANGELA GOMES & NAO \\
\hline ROSSONI & $\mathrm{NAO}$ \\
\hline RUBENS BUENO & NAO \\
\hline RUBENS OTONI & SIM \\
\hline RUBENS PEREIRA JUNIOR & SIM \\
\hline SAGUAS MORAES & <-------> \\
\hline SAMUEL MOREIRA & $\mathrm{NAO}$ \\
\hline SANDES JUNIOR & NAO \\
\hline SANDRO ALEX & NAO \\
\hline SARAIVA FELIPE & SIM \\
\hline SARNEY FILHO & SIM \\
\hline SERGIO BRITO & SIM \\
\hline SERGIO MORAES & $\mathrm{NAO}$ \\
\hline SERGIO REIS & SIM \\
\hline SERGIO SOUZA & SIM \\
\hline SERGIO VIDIGAL & NAO \\
\hline SERGIO ZVEITER & SIM \\
\hline SHERIDAN & $\mathrm{NAO}$ \\
\hline SIBA MACHADO & SIM \\
\hline SILAS BRASILEIRO & $\langle-----\cdot>$ \\
\hline SILAS CAMARA & SIM \\
\hline SILAS FREIRE & SIM \\
\hline SILVIO COSTA & SIM \\
\hline SILVIO TORRES & $\mathrm{NAO}$ \\
\hline SIMAO SESSIM & SIM \\
\hline SIMONE MORGADO & SIM \\
\hline SORAYA SANTOS & SIM \\
\hline SOSTENES CAVALCANTE & NAO \\
\hline STEFANO AGUIAR & NAO \\
\hline SUBTENENTE GONZAGA & NAO \\
\hline TADEU ALENCAR & NAO \\
\hline TAKAYAMA & <------> \\
\hline TENENTE LUCIO & SIM \\
\hline TEREZA CRISTINA & SIM \\
\hline TIA ERON & $\mathrm{NAO}$ \\
\hline TIRIRICA & NAO \\
\hline TONINHO PINHEIRO & SIM \\
\hline TONINHO WANDSCHEER & SIM \\
\hline ULDURICO JUNIOR & NAO \\
\hline VALADARES FILHO & NAO \\
\hline VALDIR COLATTO & SIM \\
\hline VALMIR ASSUNCAO & SIM \\
\hline VALMIR PRASCIDELLI & SIM \\
\hline VALTENIR PEREIRA & SIM \\
\hline VANDER LOUBET & SIM \\
\hline VANDERLEI MACRIS & $\mathrm{NAO}$ \\
\hline VENEZIANO VITAL DO REGO & SIM \\
\hline VICENTE CANDIDO & SIM \\
\hline VICENTINHO & SIM \\
\hline VICENTINHO JUNIOR & SIM \\
\hline
\end{tabular}




\begin{tabular}{|l|c|} 
VICTOR MENDES & SIM \\
\hline VINICIUS CARVALHO & SIM \\
\hline VINICIUS GURGEL & SIM \\
\hline VITOR LIPPI & NAO \\
\hline VITOR VALIM & NAO \\
\hline WADSON RIBEIRO & SIM \\
\hline WALDENOR PEREIRA & SIM \\
\hline WALDIR MARANHAO & SIM \\
\hline WALNEY ROCHA & NAO \\
\hline WALTER ALVES & SIM \\
\hline WALTER IHOSHI & SIM \\
\hline WASHINGTON REIS & SIM \\
\hline WELITON PRADO & NAO \\
\hline WELLINGTON ROBERTO & SIM \\
\hline WEVERTON ROCHA & NAO \\
\hline WILLIAM WOO & NAO \\
\hline WILSON FILHO & SIM \\
\hline WLADIMIR COSTA & $<----->$ \\
\hline WOLNEY QUEIROZ & NAO \\
\hline ZE CARLOS & $<----->$ \\
\hline ZE GERALDO & SIM \\
\hline ZE SILVA & NAO \\
\hline ZECA CAVALCANTI & SIM \\
\hline ZECA DIRCEU & SIM \\
\hline ZECA DO PT & SIM \\
\hline ZENAIDE MAIA & SIM \\
\hline
\end{tabular}

<-------> = ausente

Fonte: elaboração própria, a partir dos dados de votação disponibilizados pela Câmara dos Deputados. 


\section{APÊNDICE II - RESPOSTAS AO QUESTIONÁRIO}

Tabela 23 - Respostas às perguntas de múltipla escolha

\begin{tabular}{|c|c|c|c|c|c|c|c|}
\hline $\begin{array}{l}\text { Você participa de algum } \\
\text { movimento social/ ONG/ } \\
\text { organizaçāo/ partido } \\
\text { político? }\end{array}$ & \begin{tabular}{|l|} 
Você recebeu alguma \\
resposta (retorno) da sua \\
contribuição ou \\
manifestação no portal e- \\
Democracia da Câmara \\
dos Deputados?
\end{tabular} & $\begin{array}{l}\text { Você acha que sua } \\
\text { participação no portal e- } \\
\text { Democracia serviu para } \\
\text { influenciar a atuação de } \\
\text { um ou mais deputados? }\end{array}$ & $\begin{array}{l}\text { Você acha que o portal e- } \\
\text { Democracia facilita o } \\
\text { processo de participação } \\
\text { política dos cidadãos? }\end{array}$ & $\begin{array}{l}\text { Você considera sua participaçăo no e- } \\
\text { Democracia como }\end{array}$ & $\begin{array}{l}\text { Em termos gerais, além } \\
\text { do e-Democracia, qual o } \\
\text { seu grau de satisfação } \\
\text { com os demais canais } \\
\text { de participação popular } \\
\text { disponibilizados pela } \\
\text { Câmara dos Deputados? }\end{array}$ & $\begin{array}{l}\text { O quanto você concorda } \\
\text { com a seguinte } \\
\text { afirmação: "A } \\
\text { democracia pode ter } \\
\text { problemas, mas é o } \\
\text { melhor sistema de } \\
\text { governo". }\end{array}$ & $\begin{array}{l}\text { Em termos gerais, qual o } \\
\text { seu grau de satisfação } \\
\text { com o funcionamento da } \\
\text { democracia no Brasil? }\end{array}$ \\
\hline Năo & Não & Não & Sim & Rara (sem muita regularidade) & Satisfeito & & Insatisfeito \\
\hline Sim & Sim & Sim & sim & Ocasional (participo, mas não todo mês) & canais de participação & Concordo totalmente & Insatisfeito \\
\hline Não & Não & Não & Sim & Rara (sem muita regularidade) & Insatisfeito & Concordo totalmente & Muito insatisfeito \\
\hline Sim & Sim & Não sei & Sim & Rara (sem muita regularidade) & canais de participação & Concordo totalmente & Insatisfeito \\
\hline Sim & $\operatorname{sim}$ & Sim & $\operatorname{sim}$ & Rara (sem muita regularidade) & Satisfeito & Discordo & Satisfeito \\
\hline Não & Não & Não sei & Sim & Ocasional (participo, mas não todo mês) & canais de participação & Concordo & Muito insatisfeito \\
\hline Sim & $\operatorname{sim}$ & Sim & $\operatorname{sim}$ & Ocasional (participo, mas não todo mês) & & Concordo totalmente & Satisfeito \\
\hline Não & Sim & Não & Sim & Rara (sem muita regularidade) & Insatisfeito & Discordo & Insatisfeito \\
\hline Năo & Não & Não & Não & Rara (sem muita regularidade) & canais de participação & Discordo & Insatisfeito \\
\hline Năo & Não & Não & Não & Rara (sem muita regularidade) & canais de participação & Discordo & Insatisfeito \\
\hline Sim & Sim & Sim & Sim & Ocasional (participo, mas não todo mês) & Satisfeito & Concordo & Insatisfeito \\
\hline Não & Não & Não sei & Não sei & Ocasional (participo, mas não todo mês) & canais de participação & Concordo & Muito insatisfeito \\
\hline Não & Não & Não & Não & Ocasional (participo, mas não todo mês) & Insatisfeito & Concordo totalmente & Insatisfeito \\
\hline Năo & Sim & Não & Não sei & Ocasional (participo, mas não todo mês) & canais de participação & Concordo & Insatisfeito \\
\hline Năo & Não & Não sei & Sim & Ocasional (participo, mas não todo mês) & Insatisfeito & Concordo & Insatisfeito \\
\hline Não & Năo & Não & Não sei & Rara (sem muita regularidade) & Insatisfeito & Discordo totalmente & Muito insatisfeito \\
\hline Não & Não & Não & Não & Ocasional (participo, mas não todo mês) & Insatisfeito & Concordo & Insatisfeito \\
\hline Năo & Sim & Não & Não & Ocasional (participo, mas não todo mês) & canais de participação & Concordo totalmente & Insatisfeito \\
\hline Năo & Não & Não & Sim & Ocasional (participo, mas não todo mês) & & Concordo totalmente & Muito insatisfeito \\
\hline Não & Sim & Não sei & Sim & Rara (sem muita regularidade) & canais de participação & Concordo & Insatisfeito \\
\hline Não & Não & Não & Sim & Rara (sem muita regularidade) & canais de participação & Concordo & Muito insatisfeito \\
\hline Não & Não & Não sei & Sim & Rara (sem muita regularidade) & Muito insatisfeito & Concordo totalmente & Insatisfeito \\
\hline Sim & Não & Não sei & Sim & Rara (sem muita regularidade) & canais de participação & Concordo & Insatisfeito \\
\hline Não & Não & Não sei & Não sei & Rara (sem muita regularidade) & canais de participação & Concordo & Muito insatisfeito \\
\hline Não & Não & Não & Não sei & Rara (sem muita regularidade) & Satisfeito & Discordo & Muito insatisfeito \\
\hline Não & Sim & Não sei & Sim & Ocasional (participo, mas não todo mês) & Satisfeito & Concordo totalmente & Insatisfeito \\
\hline Năo & Sim & Não sei & Sim & por mês) & Satisfeito & Concordo totalmente & Insatisfeito \\
\hline Năo & Não & Não sei & Não & Ocasional (participo, mas não todo mês) & Muito insatisfeito & Concordo & Muito insatisfeito \\
\hline Não & Não & Não sei & Năo & Ocasional (participo, mas não todo mês) & Muito insatisfeito & Concordo & Muito insatisfeito \\
\hline Não & Não & Não & $\operatorname{sim}$ & Rara (sem muita regularidade) & canais de participação & Concordo totalmente & Insatisfeito \\
\hline Não & Sim & Não & $\operatorname{sim}$ & Rara (sem muita regularidade) & $\begin{array}{l}\text { Não conheço os demais } \\
\text { canais de participação } \\
\text { popular da Câmara dos } \\
\text { Deputados }\end{array}$ & Concordo totalmente & Muito insatisfeito \\
\hline \begin{tabular}{|l} 
Não \\
\end{tabular} & Não & Não & Sim & Rara (sem muita regularidade) & & $\begin{array}{l}\text { Concordo totalmente } \\
\end{array}$ & Muito insatisfeito \\
\hline Sim & Năo & Năo sei & Nāo & Ocasional (participo, mas não todo mês) & Insatisfeito & Concordo & Satisfeito \\
\hline \begin{tabular}{|l|l|} 
Năo \\
\end{tabular} & Não & Não sei & Sim & Ocasional (participo, mas não todo mês) & Satisfeito & $\begin{array}{l}\text { Concordo totalmente } \\
\end{array}$ & Insatisfeito \\
\hline Não & Năo & Não & Não & Ocasional (participo, mas não todo mês) & Insatisfeito & Discordo & Insatisfeito \\
\hline Sim & Sim & Sim & $\operatorname{sim}$ & Ocasional (participo, mas não todo mês) & \begin{tabular}{|l|}
$\begin{array}{l}\text { Não conheço os demais } \\
\text { canais de participação } \\
\text { popular da Câmara dos } \\
\text { Deputados }\end{array}$ \\
\end{tabular} & Concordo totalmente & Insatisfeito \\
\hline Sim & Năo & Năo & Não & Ocasional (participo, mas não todo mês) & Muito insatisfeito & Concordo totalmente & Muito insatisfeito \\
\hline Não & Não & Não & Sim & Ocasional (participo, mas não todo mês) & \begin{tabular}{|l|} 
Não conheço os demais \\
canais de participação \\
popular da Câmara dos \\
Deputados
\end{tabular} & Não sei & Muito insatisfeito \\
\hline Não & Não & Não & Não & Rara (sem muita regularidade) & $\begin{array}{l}\text { Não conheço os demais } \\
\text { canais de participação } \\
\text { popular da Câmara dos } \\
\text { Deputados }\end{array}$ & Discordo & Muito insatisfeito \\
\hline Não & Não & Sim & Sim & $\begin{array}{l}\text { Frequente (participo ao menos uma vez } \\
\text { por mês) }\end{array}$ & Muito insatisfeito & Concordo totalmente & Muito insatisfeito \\
\hline Sim & Não & Não sei & Não sei & Ocasional (participo, mas não todo mês) & \begin{tabular}{|l|} 
Não conheço os demais \\
canais de participação \\
popular da Câmara dos \\
Deputados
\end{tabular} & Concordo totalmente & Muito insatisfeito \\
\hline Sim & Sim & Não sei & $\operatorname{sim}$ & Rara (sem muita regularidade) & \begin{tabular}{|l|} 
Não conheço os demais \\
canais de participação \\
popular da Câmara dos \\
Deputados
\end{tabular} & Concordo totalmente & Muito satisfeito \\
\hline Não & Sim & Não sei & Sim & $\begin{array}{l}\text { Frequente (participo ao menos uma vez } \\
\text { por mês) }\end{array}$ & Satisfeito & Concordo totalmente & Muito satisfeito \\
\hline
\end{tabular}

Fonte: elaboração própria. 
Figura 51 - Respostas à pergunta aberta

1. Acho interessante maior divulgação do e-Democracia e da programação da TV Câmara entre os professores e estudantes, principalmente de ensino médio e superior. Percebi que mesmo nos cursos de ciências sociais a maioria dos professores não estimula os alunos a assistir a TV Câmara, preferindo discutir notícias distorcidas veiculadas pelos grandes jornais, por exemplo. Uma estratégia poderia ser bolar um concurso em nível nacional que envolvesse esse público.

2. A participação é nula se não for seriamente considerada pelos parlamentares.

3. SERMOS OUVIDOS.

4. PARLAMENTARISMO.

5. As sugestões populares poderiam ser mais discutidas pelos parlamentares. Como por exemplo, uma sessão específica para isso.

6. Se eu falar o que penso, logo outro mais bem requisitado da "democracia" dos que detém o poder vai me ofuscar com sua incrível opinião de mais do mesmo. Não obrigado, não acredito nessa ferramenta... ninguém acredita. Porque essa democracia que se pensa simplesmente não existe

7. Sou a favor da criação de uma norma geral para assegurar a todos os cidadãos mecanismos básicos de participação via internet nas Câmaras Municipais e nas Assembleias Legislativas. Sugiro a criação de um cadastro geral em que o eleitor em dia com suas obrigações eleitorais se apresentaria em qualquer casa legislativa do país portando o seu título, faria um cadastro presencial, registraria sua senha e, por meio de um sistema único, passaria a ter acesso participativo tanto na Câmara Federal, como na Assembleia Legislativa e Câmara Municipal de sua cidade. Com isso, as enquetes e demais tipos de consulta ganhariam maior validade e estaríamos valorizando mais o título eleitoral como documento dando a ele um uso mais amplo e destinado ao exercício da democracia.

8. De nada vai adiantar os canais se os parlamentares não nos serem ouvidos.

9. O problema não necessariamente está nos meios de participação popular com a Câmara, mas no fato de os deputados ignorarem o que é debatido lá. Como exemplo cito a reforma política que foi votada pelos deputados, os quais ignoraram muito do que foi debatido no fórum do e-democracia e acabaram formulando uma reforma que era única e exclusivamente do interesse deles, deixando de lado o interesse da população.

10. Voto distrital. 
11. Que se abrisse um canal de debates com temas de interesse geral que mexeria com a vida das pessoas.

12. Reforma eleitoral que impeça o poder econômico.

13. Que seja implantada a assinatura de projetos via internet.

\section{INTERAÇÃO DOS POLÍTICOS.}

15. Já falei tudo no e-Democracia em 2013... no da Reforma Política...

16. Que o eleitor receba relatórios dos votos do seu deputado e que possa responder enquetes para nortear os votos do seu representante.

17. Que a Câmara se torne mais próxima dos cidadãos, em especial no interior do país, com a descentralização de comissões e audiências públicas.

18. Democracia participativa e não representativa.

19. Sim. Gostaria que os participantes pudessem participar de uma audiência pública ou congresso sobre o tema na Câmara dos Deputados ou Senado Federal.

20. Sim. Precisamos realizar um grande encontro com os cidadãos participantes deste canal, a fim de discutir qual é o Congresso Nacional que nós queremos que nos represente.

21. Trazer as comissões da câmara dos deputados para dentro dos municípios dos estados brasileiros através de eventos ao ar livre com debates .

22. Criação de um programa em forma de telejornal na TV Câmara para exibir as votações diárias e as posições e como cada um dos deputados federais votaram.

23. Acredito que a divulgação e a formação politizada nas escolas desde o ensino básico até a pós graduação seria um avanço para a participação popular.

\section{SIM. PARLAMENTARISMO MONÁRQUICO.}

25. Cada deputado deveria direcionar uma parte da verba destinada ao gabinete para financiar um instituto de pesquisa que mensure a interação popular com o legislativo por região, onde os valores gastos devem obedecer as leis de transparência publica, também para criação de um portal que amplamente divulgue a decisão de cada voto do politico em cargo legislativo para que se possa junto aos órgãos de pesquisa relacionar as atividades legislativas ao interesse popular. 
26. Democracia mais direta com a participação mais efetiva no resultado das votações que decidem o futuro do país.

27. Mais espaço para votação do público.

28. Fim do financiamento empresarial de campanhas.

29. Fazer com que os deputados tenham obrigação de ler e dar feedback sobre as propostas. talvez, até mesmo dar poder de voto para a participação popular.

30. Plebiscitos. Previsto na Constituição e eles não fazem.

31. Deveria haver uma divulgação maior a respeito das sugestões populares neste canal. Sei que minha sugestão foi igual a muitas, no entanto, não sei bem a conta exata. Seria interessante para que, de alguma forma, a sociedade ficasse sabendo e, assim, poderia pressionar mais estes representantes do "povo".

\section{Democracia Direta.}

\section{Sim. Várias sugestões.}

34. Prezados, a população do Brasil, ao mesmo tempo que se compõe como civilização, de outra forma se deteriora pelo fomento de que nada é possível, que tudo está dominado pela "fraude e corrupção" e, quem não faz fraude ou corrupção é tido como IMBECIL e que não adianta, o Brasil é assim mesmo. Pasmem, isso são formas de expressão posta por muitos engenheiros, advogados, contadores e por aí vai, em todas as profissões consideradas "Regulamentadas", e não são apenas um ou dois. São milhares destes. Sabem quando a participação popular entenderá o que é um processo político ? O dia em que a Justiça for realmente digna e moralizada. Não gostaria de escutar quando Eu dissesse para alguém que é crime fazer licitação sem ter recursos para pagar e o objeto licitado, e este me respondesse que demoraria muito tempo Eu denunciar e alguém abrir processo. Sabem por que ele falou isso ? por que faz parte daqueles grupos que estão em todas as instituições e se protegem como "amigos íntimos", aqueles que roubam a dignidade humana. É por isso que há dificuldades de maiores participações Democráticas e de Credibilidade vista pela população.

Fonte: elaboração própria. 


\section{APÊNDICE III - QUESTIONÁRIO}

Figura 52 - Questionário para pesquisa intensiva

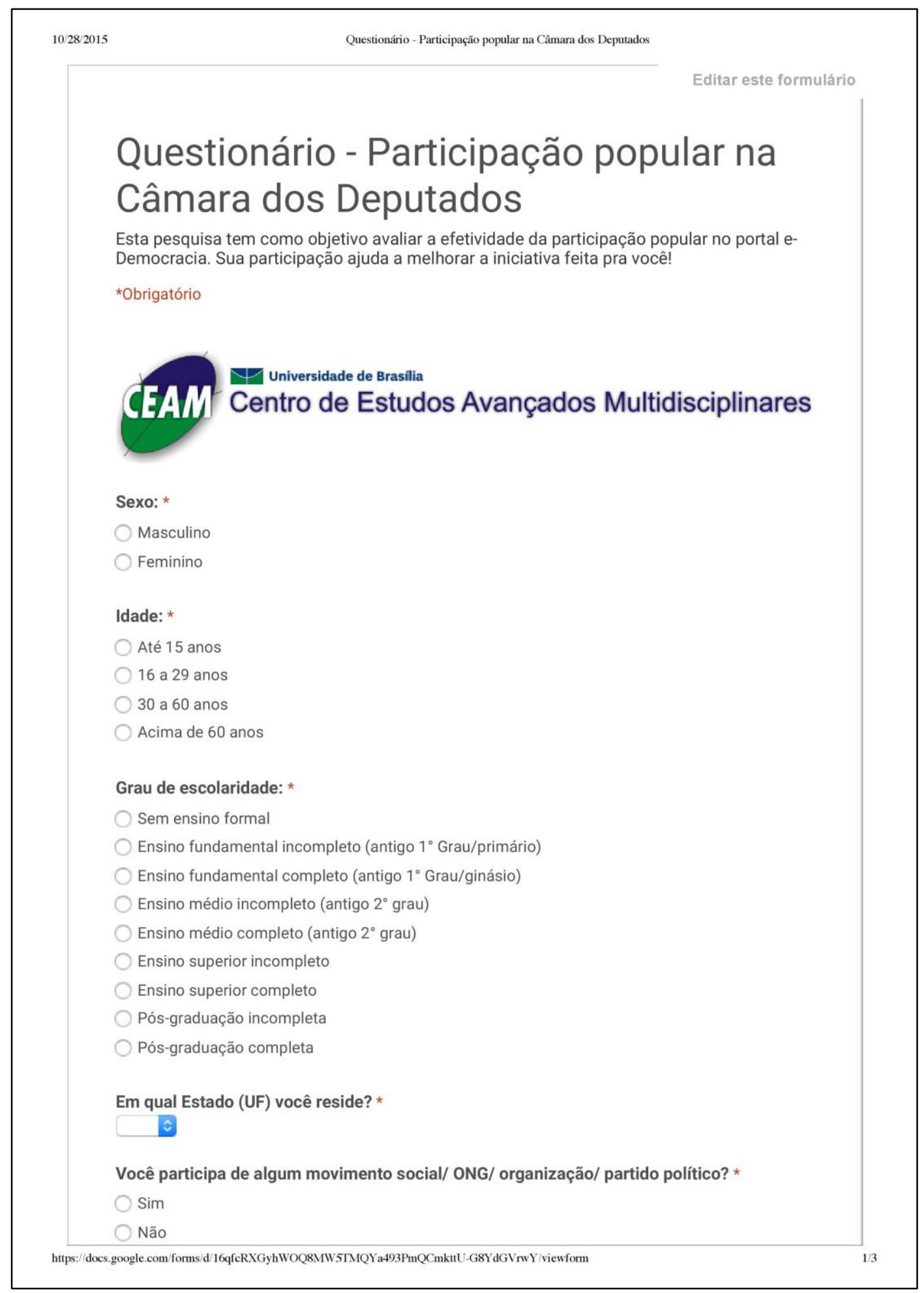


Você recebeu alguma resposta (retorno) da sua contribuição ou manifestação no portal eDemocracia da Câmara dos Deputados? *

Sim

Não

Você acha que sua participação no portal e-Democracia serviu para influenciar a atuação de um ou mais deputados? *

Sim

Não

Não sei

Você acha que o portal e-Democracia facilita o processo de participação política dos cidadãos? *

Sim

Não

Não sei

Você considera sua participação no e-Democracia como

Rara (sem muita regularidade)

Ocasional (participo, mas não todo mês)

Frequente (participo ao menos uma vez por mês)

Em termos gerais, além do e-Democracia, qual o seu grau de satisfação com os demais canais de participação popular disponibilizados pela Câmara dos Deputados?

Muito satisfeito

Satisfeito

Insatisfeito

Muito insatisfeito

Não conheço os demais canais de participação popular da Câmara dos Deputados

O quanto você concorda com a seguinte afirmação: "A democracia pode ter problemas, mas é o melhor sistema de governo".

Concordo totalmente

Concordo

Discordo

Discordo totalmente

Não sei

Em termos gerais, qual o seu grau de satisfação com o funcionamento da democracia no Brasil?

Muito satisfeito

Satisfeito 


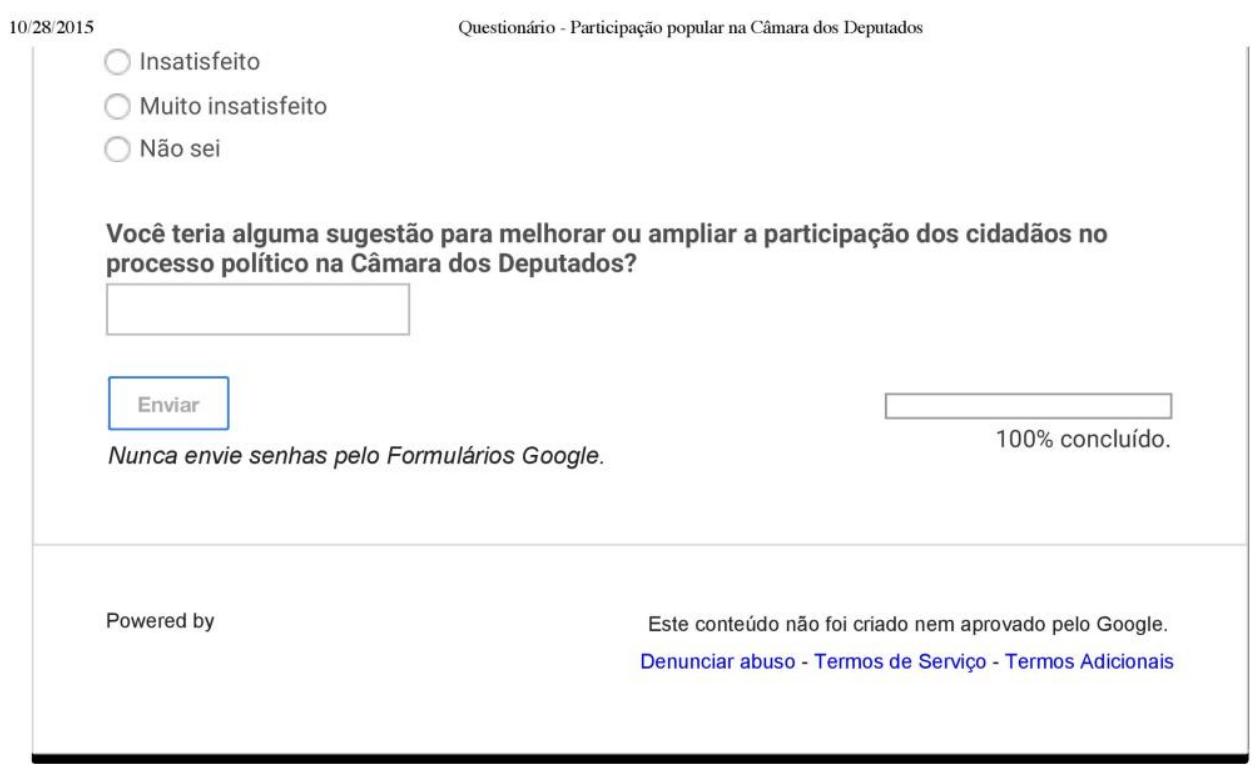

Denunciar abuso - Termos de Serviço - Termos Adicionais

Fonte: elaboração própria. 